\title{
Perinatal brain damage : possible therapeutic approaches to hypoxic-ischemic cerebral injury, studied in fetal animals
}

Citation for published version (APA):

Garnier, Y. (2003). Perinatal brain damage : possible therapeutic approaches to hypoxic-ischemic cerebral injury, studied in fetal animals. [Doctoral Thesis, Maastricht University]. Shaker Verlag. https://doi.org/10.26481/dis.20030117yg

Document status and date:

Published: 01/01/2003

DOI:

10.26481/dis.20030117yg

Document Version:

Publisher's PDF, also known as Version of record

Please check the document version of this publication:

- A submitted manuscript is the version of the article upon submission and before peer-review. There can be important differences between the submitted version and the official published version of record.

People interested in the research are advised to contact the author for the final version of the publication, or visit the DOI to the publisher's website.

- The final author version and the galley proof are versions of the publication after peer review.

- The final published version features the final layout of the paper including the volume, issue and page numbers.

Link to publication

\footnotetext{
General rights rights.

- You may freely distribute the URL identifying the publication in the public portal. please follow below link for the End User Agreement:

www.umlib.nl/taverne-license

Take down policy

If you believe that this document breaches copyright please contact us at:

repository@maastrichtuniversity.nl

providing details and we will investigate your claim.
}

Copyright and moral rights for the publications made accessible in the public portal are retained by the authors and/or other copyright owners and it is a condition of accessing publications that users recognise and abide by the legal requirements associated with these

- Users may download and print one copy of any publication from the public portal for the purpose of private study or research.

- You may not further distribute the material or use it for any profit-making activity or commercial gain

If the publication is distributed under the terms of Article $25 \mathrm{fa}$ of the Dutch Copyright Act, indicated by the "Taverne" license above, 


\section{Perinatal Brain Damage -}

\section{POSSIBLE THERAPEUTIC APPROACHES TO HYPOXIC-ISCHEMIC CEREBRAL INJURY, STUDIED IN FETAL ANIMALS}

\section{PROEFSCHRIFT}

ter verkrijging van de graad van doctor aan de. Universiteit Maastricht, op gezag van de Rector Magnificus,

Prof. Dr. A.C. Nieuwenhuijzen Kruseman, volgens het besluit van het College van Decanen, in het openbaar te verdedigen op vrijdag 17 januari 2003 om 12.00 uur

door

Yves Garnier

geboren te Giessen, Duitsland op november 16, 1970 


\section{Promotores: Pof. Dr. J. de Haan \\ Prof. Dr. A. Jensen, \\ (Ruhr-University, Bochum, Germany)}

Beoordelingscommissie: Prof Dr. J.Troost (Voorzitter)

Prof. Dr. C.E. Blanco

Prof. Dr. M.A. Hanson,

(Princess Anne Hospital, Southampton, UK.)

Prof. Dr. D.G. Kieback

Prof. Dr. H. Steinbusch 
Berichte aus der Medizin

\author{
Yves Garnier
}

\title{
Perinatal Brain Damage
}

\author{
Possible Therapeutic Approaches \\ to Hypoxic-Ischemic Cerebral Injury, \\ Studied in Fetal Animals
}

Shaker Verlag

Aachen 2003 


\section{Die Deutsche Bibliothek - CIP-Einheitsaufnahme}

Garnier, Yves:

Perinatal Brain Damage: Possible Therapeutic Approaches to

Hypoxic-Ischemic Cerebral Injury, Studied in Fetal Animals/

Yves Garnier. Aachen : Shaker, 2003

(Berichte aus der Medizin)

Zugl.: Universiteit Maastricht, Proefschrift, 2003

ISBN3-8322-0943-3

Copyright Shaker Verlag 2003

All rights reserved. Nopart of this publication may be reproduced, stored in a retrieval system, or transmitted, in any form or by any means, electronic, mechanical, photocopying, recording or otherwise, without the prior permission of the publishers.

Printed in Germany.

ISBN 3-8322-0943-3

ISSN 0945-0890

Shaker Verlag GmbH • P.O. BOX 101818 - D-52018 Aachen

Phone: 0049/2407/9596-0 - Telefax: 0049/2407/9596-9

Internet:www.shaker.de·eMail:info@shaker.de 
Aan Claudia Felicitas Aan Marie Florence en Anne Claire 


\section{ontents}

Chapter 1 General Introduction And Objectives of The Study

Chapter 2 Perinatal Brain Damage: Underlying Mechanisms

And Neuroprotective Strategies.

A Review Of The Literature

Chapter 3 Material And Methods

Chapter 4 Low Dose Flunarizine Does Not Affect Short Term

Fetal Circulatory Responses To Acute Asphyxia

In Sheep Near Term

Reproduction, Fertility and Development, 1998:10:405-411

Chapter 5 Low Dose Flunarizine Protects The Fetal Brain

From Ischemic Injury In Sheep

Pediatric Research, 1998;44:1-6

Chapter 6 Circulatory Responses To Acute Asphyxia Are Not

Affected By The Glutamate Antagonist Lubeluzole In Fetal Sheep Near Term

Journal of the Society for Gynecologic Investigation, 2001; 8:143-148 
Chapter 7 Lubeluzole Pretreatment Does Not Provide Neuro-

Protection Against Transient Global Cerebral

Ischemia In Fetal Sheep Near Term

Pediatric Research, 2002;51:517-522

Chapter 8 Neuroprotective Effects Of Magnesium On Metabolic

Disturbances In Fetal Hippocampal Slices After

Oxygen-Glucose Deprivation:

Mediation By Nitric Oxide System

Journal of the Society for Gynecologic Investigation, 2002;9:86-92

Chapter 9 Effects Of Mild Hypothermia On Metabolic

Disturbances In Fetal Hippocampal Slices After

Oxygen-Glucose Deprivation Depend On Depth And Time Delay Of Cooling

Journal of the Society for Gynecologic Investigation, 2001;8:198-205

Chapter 10 Summary, Conclusions, and Future Perspectives

Hoofdstuk 10 Samenvatting, Conclussie en Toekomstperspectief

Publications

Curriculum vitae

Acknowledgements 


\section{Abbreviations}

\begin{tabular}{|c|c|}
\hline $\mathrm{ACh}$ & acetylcholine \\
\hline aCSF & artificial cerebrospinal fluid \\
\hline ADP & adenosine-diphosphate \\
\hline AMP & adenosine-monophosphate \\
\hline AMPA & $\begin{array}{l}\alpha \text {-Amino-3-hydroxy-5-methyl-4- } \\
\text { isoxazolpropionacid }\end{array}$ \\
\hline $\mathrm{AOCC}$ & $\begin{array}{l}\text { 15oxazolpropionacid } \\
\text { agonist-operated calcium channels }\end{array}$ \\
\hline ATP & adenosine- 5 -triphosphate \\
\hline $\mathrm{BE}$ & base-excess \\
\hline BP & blood pressure \\
\hline $\mathrm{CA}$ & Cornu ammonis, part of the hippocampus \\
\hline cAMP & cyclic adenosine $-3^{\prime}, 5^{\prime}$-monophosphate \\
\hline $\mathrm{Ca}^{2+}$ & calcium \\
\hline CBF & cerebral blood flow \\
\hline cGMP & cyclic guanosine- $3^{\prime}, 5^{\prime}$-monophosphate \\
\hline EDRF & endothelium-derived-relaxing-factor \\
\hline FFA & free fatty acids \\
\hline FHR & fetal heart rate \\
\hline GTP & guanosine- $5^{-}$-triphosphate \\
\hline HIE & hypoxic-ischemic encephalopathy \\
\hline IL & interleukin \\
\hline IUGR & intrauterine growth retardation \\
\hline -NAME & $\mathrm{N}^{\prime \prime}$-Nitro-L-arginine methyl ester (NOS inhibitor) \\
\hline L-NNA & $\mathrm{N}^{\prime \prime}$-Nitro-L-arginine (NOS inhibitor) \\
\hline L.PS & lipopolysaccharide \\
\hline MABP & mean arterial blood pressure \\
\hline $\mathrm{Mg}^{2+}$ & magnesium \\
\hline $\mathrm{MgSO}_{4}$ & magnesium-sulfate \\
\hline NMDA & $\mathrm{N}$-methyl-D-aspartate \\
\hline NO & nitric oxide \\
\hline NOS & nitrix oxide synthase \\
\hline OGD & oxygen-glucose deprivation \\
\hline PAF & platelet aggregating factor \\
\hline PSR & protein synthesis rate \\
\hline $\mathrm{SO}_{2}(\%)$ & fetal arterial oxygen saturation \\
\hline TNF- $\alpha$ & tumor necrosis factor-alpha \\
\hline VSCC & voltage-sensitive calcium channels \\
\hline $\mathrm{XDH}$ & xanthine dehydrogenase \\
\hline $\mathrm{XO}$ & xanthine oxidase \\
\hline
\end{tabular}




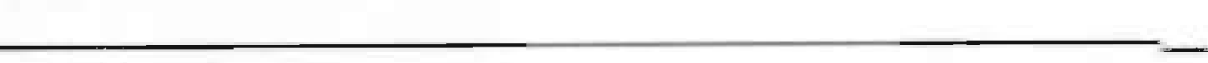




\section{Chapter 1}

\section{GENERAL INTRODUCTION AND OBJECTIVES OF THE STUDY}




\subsection{INTRODUCTION}

Perinatal brain injury is a major contributor to perinatal morbidity and mortality (Volpe 1995). In Germany alone approximately one thousand children per year experience brain damage from perinatal hypoxic-ischemic insults. A considerable number of these chiljren will develop cerebral palsy. The resulting impact on the children affected and their families is considerable and their subsequent care requires a high level of commitment and cooperation between pediatricians, child neurologists, physio-, speech- and psychotherapists, and other specialists. Despite the severe clinical and socio-economic significance, the efficacy of present clinical strategies is too low to reduce the incidence of periratal hypoxic-ischemic brain damage significantly. However, an increasing number of experimental studies describe the pathophysiological mechanisms that are involved in perinatal brain injury. Based on these pathophysiological mechanisms a variety of excellent neuroprotective strategies have been developed in various animal models for review: Berger and Garnier 1999). Obstetricians and neonatologists now face the important task of testing these neuroprotective strategies in clinical trials.

The following chapter presents our current understanding of the pathophysiology of hypoxic-ischemic brain damage in mature neonates. The situation in premature neonates is discussed separately wherever necessary. The review of the literature starts with the causes of ischemic brain lesion, especially intrauterine asphyxia and hypoxia of the fetus, and their effects on the cardiovascular system and cerebral perfusion. Asphyxia is defined as the clinical condition of impaired exchange of respiatory gases. Biochemically, asphyxia indicates the combination of oxygen lack with acidemia. Oxygen lack without an. accompanying acidemia is called hypoxia (low oxygen tension) or hypoxemia (low percent saturated hemoglobin).

The typical neuropathological findings arising from reduced perfusion of the fetal brain are described. Also of key importance are the cellular mechanisms that are triggered by an ischemic insult. These will be discussed in detail, with particular emphasis on alterations of energy metabolism, intracellular calcium accumulation, the release of excitatory amino acids and protein biosynthesis. Focal cerebral ischemia is characterized by an ischemic core and a peri-infarct region known as ischemic penumbra. The ischemic penumbra is defined as a moderately hypoperfused region that retains structural integrity but has lost function. In animal models of ischaemic stroke, this region is prone to recurrent anoxic depolarization and will become infarcted if reperfusion does not occur (for review: Heiss and Graf 1994). As shown in previous studies, glutamate is released in tremendous amounts from the infarct core into the extracellular space after focal cerebral ischemia. 
Increases of up to 80 times above baseline levels have been observed (Hillered et al. 1989). The released glutamate activates the neuronal NO-synthase via calcium influx through NMDA-regulated calcium channels (East and Garthwaite 1991). In focal ischemia this pathway may be of greater importance for the development of neuronal cell damage than in global cerebral ischemia, since in the latter type of ischemia only a moderate and shortlasting increase in glutamate release has been observed (Hagberg et al. 1987).

A considerable portion of neuronal cell damage first occurs during the reperfusion phase following an ischemic insult. The formation of oxygen radicals, induction of the nitric oxide system, inflammatory reactions and apoptosis will therefore be discussed in depth in this context. Finally, therapeutic concepts will be presented that have been developed out of our understanding of these pathophysiological processes and have been tested in animal experiments. Of these, postischemic induction of mild cerebral hypothermia, the application of the calcium-antagonist flunarizine and the administration of magnesium appear to be of the greatest clinical relevance.

\subsection{OBJECTIVES OF THE STUDY}

In experimental animal models of focal and global cerebral ischemia, flunarizine has shown to be neuroprotective when given before, but not after, the insult (Van Reempts et al. 1983; Silverstein et al. 1986; Gunn et al. 1989; Chumas et. al. 1993; Gunn et al. 1994). In some of these studies flunarizine was applied at relatively high doses (i.e., $30 \mathrm{mg} / \mathrm{kg}$ body weight) before hypoxia-ischemia. The high dose regimens used had severe cardiovascular side-effects. The purpose of the studies given in Chapters 4 and 5 was, therefore, to find a therapeutic regimen that does not alter the fetal cardiovascular responses to intrauterine asphyxia but reduces cerebral damage after global cerebral ischemia in fetal sheep.

Lubeluzole, the S-isomer of a novel 3,4-difluoro benzothiazole, has been shown to reduce ischemic neuronal cell damage in a variety of in-vitro as well as in-vivo studies (Aranowski et al. 1996; Buchkremer-Ratzmann et al. 1997; Culmsee et al. 1998; De Ryck et al. 1995, 2000; Haseldonckx et al 1997). The present knowledge on the safety profile and efficiency of lubeluzole seems to be promising enough to warrant further studies in immature animals. Preliminary experiments in our laboratory have demonstrated transient alterations in heart rate as well as arterial hypertension after intravenous application of this compound in late-gestation fetal sheep. Thus, it was thought that any possible 
neuroprotective effect of this drug might be counteracted by an impairment of fetal cardiovascular control during hypoxia. The mature fetal sheep reacts to an episode of acute hypoxia with bradycardia and redistribution of combined ventricular output to the central and vital organs, such as the heart, brain, and adrenal glands at the expense of peripheral organs, including lungs, kidneys, gastrointestinal tract, and carcass, containing skin, bones, and muscle (Jensen et al. 1987. This crucial mechanism protects the fetal brain from neuronal injury by increasing cerebral perfusion when oxygen is in short supply. The aim of the present study was therefore to examine in detail whether lubeluzole affects circulatory responses to acute asphyxia in fetal sheep near term (Chapter 6). Furthermore, the cerebroprotective properties of lubeluzole were studied in a fetal sheep model of global cerebral ischemia. In this model we determined the time course of changes in organ blood flow during and after cerebral ischemia using the microspheres method. Using this model, we were able to account for drug-related changes in cerebral blood flow that might affect neuronal cell damage (Chapter 7).

Since the retrospective analysis of Nelson and Grether (1995) showing that magnesium, a well-known tocolytic agent, also has neuroprotective properties, its use in perinatology is very encouraging. However, the existing data is very non-uniform. Both protective and non-protective effects have been reported with different timing of administration at different stages of development. Furthermore, the physiological mechanisms through which a possible neuroprotective effect of magnesium could be mediated are not well understood. Therefore, the effects of magnesium on metabolic disturbances in fetal brain during and after ischemia were investigated, while excluding its effects on the fetal cardiovascular system. For this purpose we used the in-vitro system of oxygen-glucose deprivation (OGD) in hippocampal tissue slices prepared from mature guinea pig fetuses. Metabolic disturbances were assessed by measuring changes in energy metabolism and protein synthesis. In addition we determined cGMP concentrations in the tissue slices after OGD, as a measure of NO-production, to clarify whether a possible neuprotective effect of magnesium is mediated in part through the NO-system (Chapter 8 ).

In vitro models of hypoxia-ischemia have some advantages over in vivo models, including the ability to control or eliminate such variables as blood flow, temperature, ionic environment, nutrient availability, and the ability to serially assess injury or injury surrogates, such as impaired energy metabolism and prolonged inhibition of protein synthesis, respectively. However, multiple in vitro models used for examining neuroprotective properties of drugs have limitations that may restrict their ability to predict neuroprotective efficacy in intact animals. For example, in dissociated cell cultures, the anatomic relations of neurons, glia, and synapses are lost and sensitivity to anoxia or 
hypoxia-ischemia is much reduced compared with intact animals. In acutely prepared and studied brain slices, anatomic integrity is preserved. Moreover, the hippocampal slice model of cerebral oxygen-glucose deprivation retains the sensitivity to anoxia.

The cerebroprotective properties of mild cerebral hypothermia are discussed in chapter 9. There is a growing body of evidence from animal experiments and clinical studies in asphyxiated newborns that mild hypothermia (selective head cooling) induced during or even after cerebral ischemia may protect the fetal and neonatal brain from neuronal cell damage (Gunn et al. 1997:1998a,b). However, the exact interrelation between the postischemic time delay and the degree of mild hypothermia by which neuroprotective effects on ischemic insults of different severity can be achieved has not yet been systematically elucidated. To clarify this point we studied the interaction between these variables in a recently modified hippocampal tissue slice model. We used hippocampal tissue since it is well known that this kind of brain tissue shows a high metabolic sensitivity. Thus, it was shown that already 5 min ischemia are sufficient to produce irreversible inhibition of protein synthesis, followed by delayed neuronal death, in the selectively vulnerable CAI sector of the hippocampus, while other parts of the brain are much less vulnerable (Bodsch et al. 1985).

\subsection{REFERENCES}

1. Aranowski J, Strong R, Grotta JC: Combined neuroprotection and reperfusion therapy for stroke. Effect of lubeluzole and diaspirin cross-linked hemoglobin in experimental focal ischemia. Stroke 27 (1996) 1571-1577

2. Berger R, Garnier Y: Pathophysiology of perinatal brain damage. Brain Res Brain Res Rev 32 (1999) 107-134

3. Bodsch W, Takahashi K, Barbier A, Grosse Ophoff B, Hossmann K-A: Cerebral protein synthesis and ischemia. Progr Brain Res 63 (1985) 197-210

4. Buchkremer-Ratzmann 1, Witte OW: Pharmacological reduction of electrophysiological diaschisis after photothrombotic ischemia in rat neocortex. Eur J. Pharmacol 320 (1997) 103-109

5. Chumas PD, Del Bigio MR, Drake JM, Tuor UI: A comparison of the protective effect of dexamethasone to other potential prophylactic agents in a neonatal rat model of cerebral. hypoxia-ischemia. J Neurosurg 79 (1993) $414-420$ 
6. Culmsee C, Junker V, Wolz P, Semkova I, Krieglstein J: Lubeluzole protects hippocampal neurons from excitotoxicity in vitro and reduces brain damage caused by ischemia. Eur J Pharmacol 342 (1998) 193-202

7. De Ryck M, Scheller D, Clincke G, Janssen M, Van Reet S: Lubeluzole, a novel benzothiazole, protects neurologic function, reduces infarct size, and blocks periinfarct glutamate rise after cerebral thrombotic stroke in rats. Cerebrovasc Res 5 (1995) 264

8. DeRyck M, Verhoye M, Van der Linden: Diffusion-weighted MRI of infarct growth in a rat photochemical stroke model: effect of lubeluzole. Neuropharmacology 14 (2000) $691-702$

9. East SJ, Garthwaite J: NMDA receptor activation in rat hippocampus induces cGMP. formation through the L-arginine-nitric oxide pathway. Neurosci. Lett 123 (1991) 17 19

10. Gunn AJ, Gluckman PD, Gunn TR: Selective head cooling in newborn infants after perinatal asphyxia: A safety study. Pediatrics 102 (1998a) $885-892$

11. Gunn AJ, Gunn TR, Gunning MI, Williams CE, Gluckman PD: Neuroprotection with prolonged head cooling started before postischemic seizures in fetal sheep. Pediatrics 102 (1998b) 1098-1106

12. Gunn AJ, Gunn TR, de Haan HH, Williams CE, Gluckman PD: Dramatic neuronal rescue with prolonged selective head cooling after ischemia in fetal lambs. J Clin Invest 99 (1997) 248-256

13. Gunn AJ, Mydlar T, Bennet L, Faull RLM, Gorter S, Cook C, Johnston BM, Gluckman PD: The neuroprotective actions of a calcium channel antagonist, flunarizine, in the infant rat. Pediatr Res 25 (1989) 573-576

14. Gunn AJ, Williams CE, Mallard EC, Tan WKM, Gluckman PD: Flunarizine, a calcium channel antagonist, is partially prophylactically neuroprotective in hypoxicischemic encephalopathy in the fetal sheep. Pediatr Res 35 (1994) 657-663

15. Hagberg H, Andersson P, Kjellmer I, Thiringer K, Thordstein M: Extracellular overflow of glutamate, aspartate, GABA and tatrine in the cortex and basal ganglia of fetal lambs during hypoxia-ischemia. Neurosci Lett 78 (1987) 3 1 1-317

16. Haseldonckx M, Van Reempts J, Van de Ven M. Wouters L, Borgers M: Protection with lubeluzole against delayed ischemic brain damage in rats. A quantitative histopathologic study. Stroke 28 (1997) $428-432$

17. Heiss WD, Graf R: The ischemic penumbra. Curr Opin Neurol 7 (1994) 11-19

18. Hillered L. Hallstrom A, Segersvard S, Persson L. Ungersted U: Dynamics of exiracellular metabolites in the striatum after middle cerebral artery occlusion in the rat monitored by intracerebral microdialysis. J Cereb Blood Flow Metab 9 (1989) 607 616

19. Jensen A, Hohmann M, Kunzel W: Dynamic changes in organ blood flow and oxygen consumption during acute asphyxia in fetal sheep. J Dev Physiol 9 (1987) 543-559

20. Nelson KB, Grether JK: Can magnesium sulfate reduce risk of cerebral palsy in very low birthweight infants? Pediatrics 95 (1995) 263-269 
21. Silverstein FS, Buchanan K, Hudson C, Johnston MV: Flunarizine limits hypoxiaischemia induced morphologic injury in immature rat brain. Stroke 17 (1986) 477-482

22. Van Reempts J, Borgers M, Van Dael L, van Eyndhoven J, Van de Ven M: Protection with flunarizine against hypoxic-ischemic damage of the rat cerebral cortex. A quantitative morphologic assessment. Arch Int Pharmacodyn Ther 232 (1983)76-88

23. Volpe JJ: Neurology of the newborn. Philadelphia: WB Saunders, 1995 
Chapter I 


\section{Chapter 2}

\section{PERINATAL BRAIN DAMAGE: UNDERLYING MECHANISMS AND NEUROPRO'TECTIVE STRATEGIES. A REVIEW OF THE LITERATURE.}

2.1 Causes, of hypoxic-ischemic brain lesions in neonates

2.2 Circulatory centralisation and cerebral perfusion

2.3 Neuropathology of hypoxic-ischemic brain lesions

2.4 Energy metabolism and calcium homeostasis

2.5 Excitatory neurotransmitters

2.6 Protein Biosynthesis

2.7 Secondary cell damage during reperfusion

2.8 Infection related cerebral injury

2.9 Apoptosis and postischemic genome expression

2.10 Perinatal neuroprotection

2.10.1 Pharmacological intervention

2.10.2 Physiological intervention

\subsection{References}




\subsection{CAUSES OF HYPOXIC-ISCHEMIC BRAIN LESIONS IN NEONATES}

With a few exceptions, acute hypoxic-ischemic brain lesions in neonates are caused by severe intrauterine asphyxia (Volpe 1995). This was recognised as early as 1844 when Sir William John Little, a London orthopaedic surgeon, published his lectures on Deformities of the Human Frame, in which he noted the association between severe asphyxia during delivery with convulsions. Intrauterine asphyxia is usually brought about by an acute reduction in the uterine or umbilical circulation (Jensen and Berger 1991), which in turn can be caused by abruptio placentae, contracture of the uterus, vena cava occlusion syndrome, compression of the umbilical cord etc.

\subsection{CIRCULATORY CENTRALISATION AND CEREBRAL PERFUSION}

During hypoxemia and asphyxia the distribution of the combined ventricular output changes in the mature fetus much the way it does in the aduit. There is a circulatory centralization of blood flow in favour of the brain, heart, and adrenals, and at the expense of the peripheral organs, including lungs, kidneys, gastrointestinal tract, and carcass (for review: Jensen and Berger (991). The lowered oxygen and raised carbon dioxide partial pressures lead to vasodilatation of the cerebral vascular bed causing an increased cerebral blood flow. This affects the brainstem in particular, while the bood flow to the white matter of the brain is hardly increased at all (Lou et al. 1985; Ashwal et al. 1984). Depending on the extent of the oxygen deficit and the maturity of the fetus, this cerebral hyperperfusion can reach 2-3 times the original rate of blood flow. If the oxygen deficit persists the anaerobic energy reserves of the heart become exhausted. The cardiac output and the mean arterial blood pressure fall. At mean arterial blood pressures of below 25-30 $\mathrm{mmHg}$ there is an increasing loss of cerebral autoregulation, and a consequent reduction of the cerebral blood flow (Lou et al. 1979). This affects the parasagittal region of the cerebrum and the white matter most of all. Immature fetuses seem to be particularly endangered by their limited ability to increase the cerebral circulation through vasodilatation.

If cerebral autoregulation is lost, cerebral blood flow varies with arterial blood pressure, but this is not always true. For instance, during acute asphyxia, caused by arrest of uterine 
blood flow, cerebral vascular resistance increases and hence cerebral blood flow does not increase inspite of a steep increase in arterial blood pressure. Thus, under these very acute conditions, autoregulation is intact, even though arterial oxygen content is poor (Jensen and Berger 1991).

If the supply of oxygen to the fetus can be improved, cerebral hyperperfusion is brought about by the progressive postasphyxial increase in cardiac output (Jensen and Berger 1991). This hyperperfusion can be demonstrated in experiments using animal models of isolated cerebral ischemia (Fig. 1) (Berger et al. 1996c). Vasodilatation induced by acidosis in cerebral tissues and a reduction of blood viscosity at higher rates of blood flow have been put forward as possible causes of such hyperperfusion. The initial hyperperfusion of the brain is followed directly by a phase of hypoperfusion (Fig. 1) (Berger et al. 1996c; Rosenberg et al. 1989).

\section{Cerebral Blood Flow}

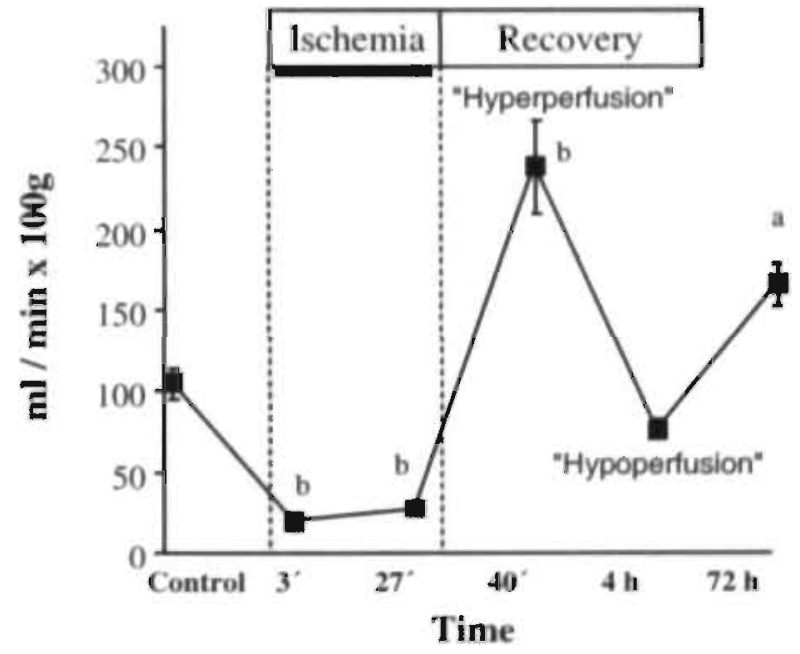

Fig. I. Blood flow to the cerebrum ( $\mathrm{mL} / \mathrm{min} \times 100 \mathrm{~g}$ tissue) in fetal sheep near term before, during and after global cerebral ischemia of 30 min. duration. Cerebral ischemia was induced by occluding both carotid arteries. Results are given as means $\pm \mathrm{SD}$ (a: $\mathrm{P}<0.01$, b: $\mathrm{P}<0.001$ (ischemia / recovery vs, control) (Berger et al. 1996c). 
Postischemic hypoperfusion may be caused by oxygen radicals formed during the reperfusion phase after ischemia. Rosenberg and co-workers demonstrated that this phenomenon can be prevented by inhibiting the synthesis of oxygen radicals after ischemia (Rosenberg et al. 1989). In addition, a so-called no-reflow phenomenon can be observed after severe cerebral ischemia. This failure of reperfusion in various brain areas is a consequence of the greater viscosity of stagnant blood, compression of the smallest blood vessels through swelling of the perivascular glial cells, formation of endothelial microvilli, increased intracerebral pressure, postischemic arterial hypotension and increased intravascular coagulation. The extent of the no-reflow phenomenon depends on the duration and type of cerebral ischemia. It is most pronounced when the vessels are engorged with blood after venous congestion (Hossmann 1993). Directly after postischemic hypoperfusion the cerebral blood flow recovers or overshoots into a second phase of hyperperfusion (Fig. 1) (Berger et al. 1996c: Pryds et al. 1990). Since this hyperperfusion is often accompanied by an isoelectric encephalogram, it is regarded as an extremely unfavourable prognostic factor (Pryds et al. 1990).

\subsection{NEUROPATHOLOGY OF HYPOXIC-ISCHEMIIC BRAIN LESIONS}

There are essentially six forms of hypoxic-ischemic brain lesion (Table 1): selective neuronal cell damage, status marmoratus, parasagittal brain damage, periventricular leucomalacia, intraventricular or periventricular haemorrhage and focal or multifocal ischemic brain lesions (Berger and Gaunier 1999; Volpe 1995).

In mature fetuses, selective neuronal cell damage is found most frequently in the cerebral cortex, hippocampus, cerebellum and the anterior horn cells of the spinal cord (Friede 1966: Larroche 1986; Norman 1978; Volpe 1995). As shown in animal experiments, the damage occurs after ischemia of only $10 \mathrm{~min}$ (Williams 1992). Within the cortex, the border zones between the major cerebral arteries are the worst affected. The cell damage is mostly parasagittal and more marked in the sulci than in the gyri, i.e. the pattern of distribution is strongly dependent on perfusion. The neurones show the most damage while the oligodendrocytes, astroglia and microglia remain largely unscathed (Volpe 1995). In contrat to the neuropathological manifestations in the term infant, in the premature infant periventricular oligodendroglial/white matter injury predominates. Our understanding of the biochemical events leading from the hypoxic-ischemic insult to the neuronal injury of 
the term infant is much better than our understanding of the events leading to the oligodendroglial injury of the premature infant. The pathophysiological mechanisms leading to the different pattern in neuronal and oligodendroglial injury will be discussed in the following sections.

Status marmonatus, which is observed in only $5 \%$ of children with hypoxic-ischemic brain lesions, chiefly affects the basal ganglia and the thalamus. The complete picture of the disease does not emerge until 8 months after birth although the insult begins to take effect during the perinatal period. Status marmoratus is characterised by loss of neurones, gliosis and hypermyelination. The increased number of myelinated astrocytic cell processes and their abnormal distribution give the structures affected, especially the putamen, a marbled appearance (Friede 1966; Rorke 1992).

Table 1. Hypoxic-Ischemic Brain Damage in the Fetus and Neonate.

Neurologic lesion

Selective neuronal necrosis

Status marmoratus

Parasaginal cerebral injury

Periventricular leucomalacia

Intra-, periventricular hemorrhage

Focal / multifocal ischemic brain damage

\section{Topographic localization}

cortex cerebri

cerebellum

hippocampus

anterior horn cells of the

spinal cord

basal ganglia

thalamus

cortex cerebri and subcortical substantia alba

substantia alba

germinal matrix

substantia alba

ventricles

cortex cerebri and subcortical substantia alba 
Parasagittal brain damage caused by cerebral ischemia is mostly reported in mture neonates (Friede 1966; Larroche 1986; Norman 1978; Volpe 1995) and affects the partal and occipital regions in particular. The damage usually arises through insuffiient perfusion of the border zones between the main cerebral arteries during cerebral ischenia. The extent of the brain lesions was found to be closely dependent on the durationand severity of the cerebral ischemia (Berger et al. 1996c; Williams et al. 1992). Interestigly. in the cortex, sulci are more badly damaged than the gyri. This arises from the special vay in which the blood vessels in the cortex and surrounding white matter develop. Wherthe sulci take shape and deepen in mature neonates, the penetrating blood vessels brancing out from the meningeal arteries are forced into a hairpin bend as they cross the border fom grey matter into white matter. This produces a triangular area within the white matter athe base of the sulci through which hardly any vessels pass. Thus any reduction inthe perfusion of this region causes most damage to the sulci of the cortex. This patten of damage seems to correspond to that observed clinically in cases of subcorical leucomalacia (Takashima et al. 1978).

Periventricular leucomalacia is characterised by damage to the white matter dorsal nd

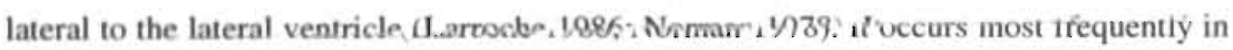
immature fetuses and chiefly affects the radiatio occipitalis at the trigonum of the lateral ventricle and the white matter around the foramen of Monro. At 6 to 12 hours after an ischemic insult necrotic foci can be observed in these areas (Banker et al. 1962). These are characterised by swelling and rupture of neuronal axons. Necrotic oligodendrocytes are also found, especially ones undergoing differentiation or taking part in myelinisation. Over the nexi 24 to 48 hours activated microglia are seen more and more frequently. In $25 \%$ of cases, periventricular leucomalacia is accompanied by parenchymatous haemorihaging (Paneth et al. 1990). As the disease progresses small cysts develop out of the necrotic foci that can be identified by ultrasonography (de Vries 1988; Paneth et al. 1990). As gliosis progresses the cysts become smaller. The lack of myelinisation owing to the destruction of the oligodendrocytes and an enlargement of the lateral ventricle then become the most. prominent features of the disease (Dambska et al. 1989; Rorke 1992; Takashima et al. 1978). Periventricular leucomalacia around the Radiatio occipitalis at the trigonum of the lateral ventricle and in the white matter around the foramen of Monro arises through vascular problems. Especially in immature fetuses, the ability to increase blood flow by vasodilatation during and after a period of arterial hypotension appears to be extremely limited in these brain areas (Szymonowicz et al. 1990). After the 32nd week of pregnancy the vascularisation of these vulnerable areas is considerably increased and the incidence of periventricular leucomalacia thereby reduced. 
Intra- or periventricular haemorrhage is another typical lesion of the immature neonate brain (Volpe 1995). It originates in the vascular bed of the germinal matrix, a brain region that gradually shrinks until it has almost completely disappeared in the mature fetus (Hambleton et al. 1976: Moody et al. 1994; Nakawara et al. 1990). Blood vessels in this brain region burst easily owing to a delay in basal lamina deposition and organization as well as delayed endothelial cell tight junction formation (Ment et al. 1995). Sub- and postpartum fluctuations in cerebral blood flow can therefore lead to rupture of these vessels causing intra- or periventricular haemorrhage (Berger et al. 1997: Funato et al. 1992; Goldberg et al. 1990; Jensen et al. 1992: Milligram et al. 1980). Microscopic studies of the periventricular hemorrhagic necrosis indicate that the lesion is often a hemorrhagic infarction (Volpe 1997). There is increasing evidence from recent elinical and experimental data that the hemorrhagic component of the infarction tends to be most concentrated near the ventricular angle where the medullary veins draining the cerebral white matter become confluent and ultimately join the terminal vein in the subependymal region. Thus, it appears likely that periventricular hemorrhagic necrosis occuring in association with large IVH is, in fact, a venous infarction (for review: Volpe 1997).

Focal or multifocal brain damage usually occurs within areas supplied by one or more of the main cerebral arteries. This form of insult is not normally observed before the 28th week of pregnancy. The incidence then rises with increasing maturity of the fetus (Barmada et al. 1979). Focal or multifocal brain lesions are often the result of infections, trauma or twin births, especially monochoriotic ones (Bejar et al. 1990; Patten et al. 1989; Scheller and Nelson 1992). It is thought that thromboplastic material or emboli from a miscarried co-twin sometimes occludes the cerebrovascular circulation of the living twin. Brain damage may also be caused by anemia or polycythemia and subsequent cardiac insufficiency and cerebral hypoperfusion arising from a feto-fetal transfusion. Alternatively, focal or multifocal brain damage can arise from systemic arterial hypotension, so that there is little distinction between this and other forms of brain damage such as selective neuronal cell damage, status marmoratus, parasagittal brain damage or periventricular leucomalacia (for review: Berger and Garnier 1999; Volpe 1995).

In this context it is important to note, that the fetal and neonatal brain possesses a enormous possibility for repair. The epidermal growth factor (EGF) family is an important regulator for tissue development and repair. Prominent members of the EGF family are transforming growth factor-alpha (TGF-alpha) and heparin-binding EGF (HB-EGF). These polypeptides, produced by neurons and glial cells, play an important role in the 
development of the nervous system, stimulating proliferation, migration, and differentiation of neuronal, glial, and Schwann precursor cells. These peptides are also neurotrophic, enhancing survival and inhibiting apoptosis of post-mitotic neurons, probably acting directly through receptors on neurons, or indirectly via stimulating glial proliferation and glial synthesis of other molecules such as neurotrophic factors. TGF. alpha, EGF, and neuregulins are involved in mediating glial-neuronal and axonal-glial interactions, regulating nerve injury responses, and participating in injury-associated astrocytic gliosis, brain tumors, and other disorders of the nerve system (for review: Xias and Zhou 2002).

\subsection{ENERGY METABOLISM AND CALCIUM HOMEOSTASIS}

The normal functioning of the brain is essentially dependent on an adequate oxygen supply to maintain energy metabolism. Whereas, during moderate hypoxemia, the fetus is able to maintain adequate levels of ATP by speeding up the rate of anaerobic glycolysis (Berger et al. 1993; 1994; 1997b), a severe reduction of the fetal oxygen supply will lead 10 a breakdown of energy metabolism in the cerebral cortex within a few minutes (Berger et al. 1991: 1992). The ionic gradients for $\mathrm{Na}^{+}, \mathrm{K}^{+}$and $\mathrm{Ca}^{2+}$ across the cell membranes can no longer be regulated since the $\mathrm{Na}^{+} / \mathrm{K}^{*}$-pump stops working through lack of energy. The membrane potential approaches $0 \mathrm{mV}$ (Hansen 1985). The energy depleted cell takes up $\mathrm{Na}^{+}$, and the subsequent fall in membrane potential induces an influx of $\mathrm{Cl}^{-}$ions. This intracellular accumulation of $\mathrm{Na}^{+}$and $\mathrm{Cl}^{-}$ions leads to swelling of the cells as water flows in through osmosis. Cell edema is therefore an inevitable consequence of cellular energy deficiency (Siesjö et al. 1992).

In addition, loss of membrane potential leads to a massive influx of calcium down the extreme extra-/intracellular concentration gradient. It is currently thought that the excessive increase in intracellular calcium levels, the so-called calcium-overload, leads to cell damage by activating proteases, lipases and endonucleases (Siesjö et al. 1992). Some of the cellular mechanisms that are activated by the calcium influx occurring during ischemia are shown in Figure $2:$ alteration of the arachidonic acid cycle affecting prostaglandin synthesis, disturbances of gene expression and protein synthesis and increased production of free radicals and obstruction of the axonal transport system through disaggregation of microtubuli. 


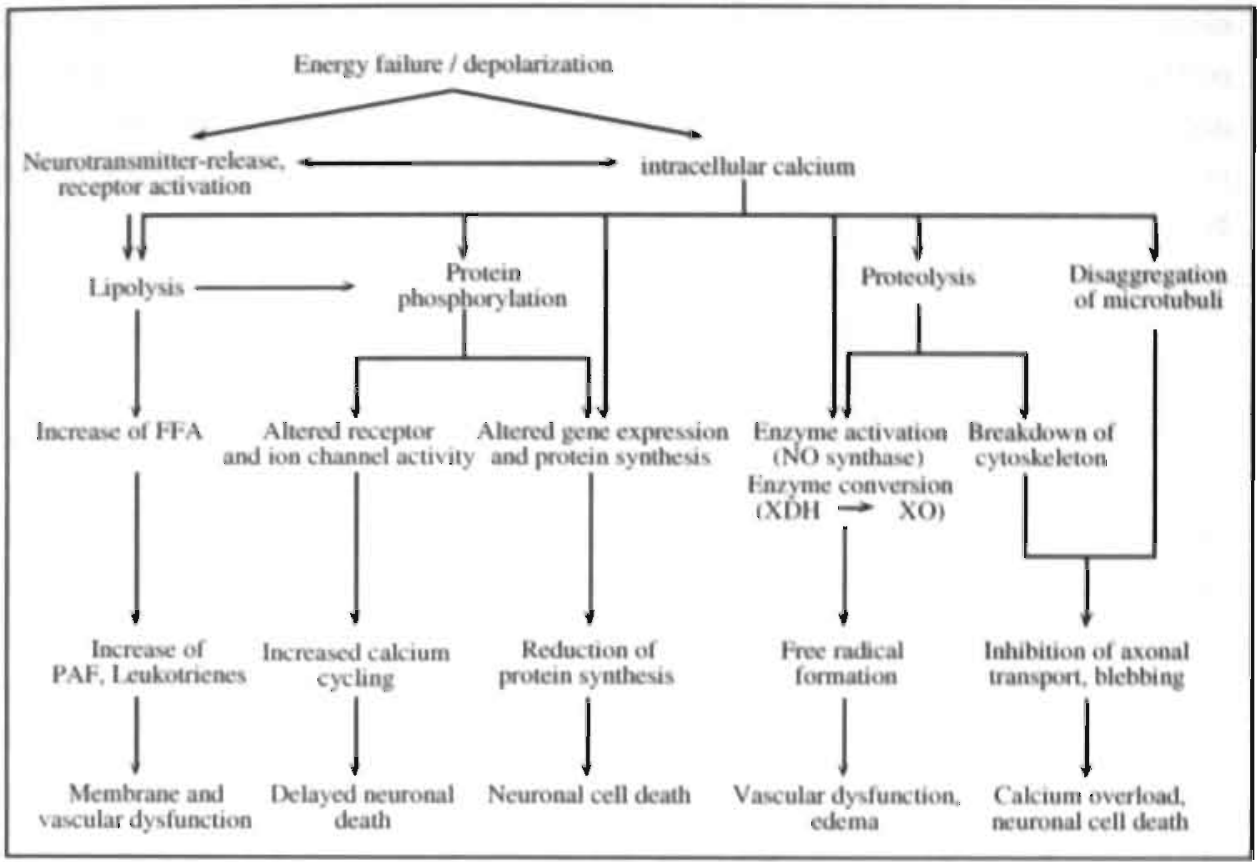

Figure 2. Diagramm illustrating the primary effects of depolarization / receptor activation and the secondary effects of an increased intracellular calcium concentration (modified from Siesjo et al. 1992). FFA, free fatty acids: NO, nitric oxide: PAF, platelet aggregating factor: $\mathrm{XDH}$, xanthine dehydrogenase; $\mathrm{XO}$, xanthine oxidase.

\subsection{EXCITATORY NEUROTRANSMITTERS}

As early as 1969 Olney succeeded in demonstrating that neuronal cell death could be induced by the exogenous application of glutamate, an excitatory neurotransmitter. In subsequent years, this observation was confirmed in both immature and adult animals of various species including primates (Olney et al. 1969). In. 1984, Rothman showed. that glutamate antagonists could prevent anoxic cell death in hippocampal tissue cultures. That same year, Benveniste et al. (1984) reported an excessive release of glutamate into the extracellular space during cerebral ischemia in vivo, from which they concluded that glutamate might play an important role in neuronal cell death following ischemia. (Palmer et al. 1990; Rothman 1984). 
Glutamate activates postsynaptic receptors that form ionic channels permeable to cations (Fig. 3) (Schoepfer et al. 1994). The NMDA-receptor regulates a calcium channel, the metabotropic receptors induce an emptying of intracellular calcium stores while the AMPA/KA receptors open a voltage-dependent calcium channel by membrane depolarisation. The increase in free calcium within the cell activates proteases, lipases and endonucleases that then initiate processes leading to cell death (Choi 1988; Siesjö and Bengtsson 1989).

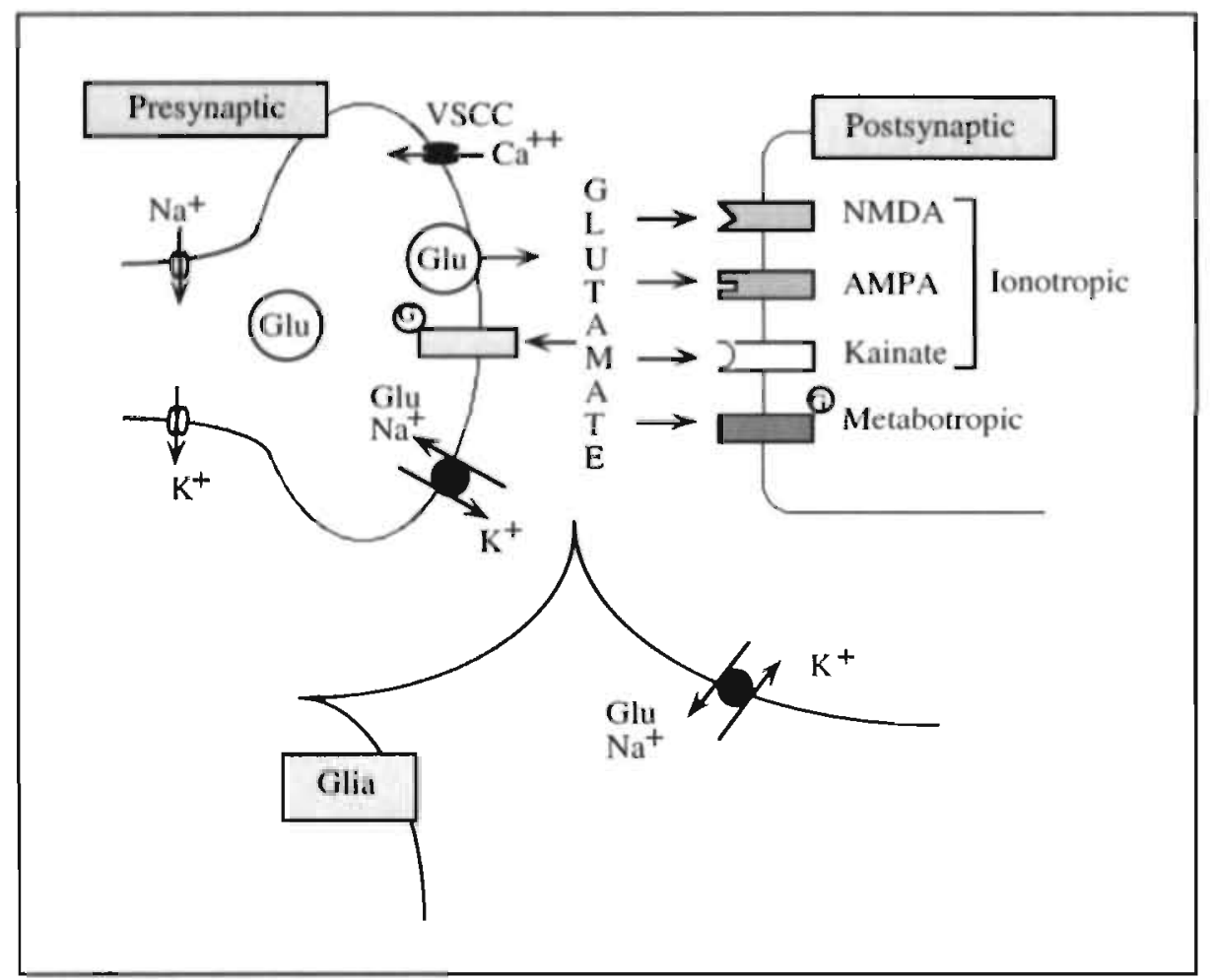

Figure 3. Determinants of glutamate-mediated synaptic transmission. The release of vesicular glutamate (exocytosis) is triggered by action potential invasion of the presynaptic terminal with subsequent depolarization and influx of $\mathrm{Ca}^{2+}$ through voltage-sensitive $\mathrm{Ca}^{2}$-channels (VSCC). Glutamate released into the synaptic cleft activates postsynaptic ionotropic receptors and pre- or postsynaptic metabotropic receptors (i.e. coupled to $\mathrm{G}$-proteins). High-affinity, $\mathrm{Na}^{+}$-dependent glutamate uptake in presynaptic and glial membranes contributes to termination of glutamate actions (modified after Obrenovitch et al. 1996). 
There is no longer any doubt that glutamate release plays a critical role in neuronal cell death after focal cerebral ischemia such as that caused by an arterial embolus. Glutamate antagonists have been shown to exert a strong neuroprotective effect against hypoxicischemic brain damage in adult (Kochhar et al. 1988; Park et al. 1988; Uematsu et al. 1991 ) and even in neonatal animals (Andine et al. 1988; Ford et al. 1989; Gilland et al. 1994; Hattori et al. 1989; McDonald et al. 1987; Nozaki and Beal 1992). In neonatal rats it was shown that glutamate release during and after an hypoxic-ischemic insult could evoke epileptogenic activity and that this effect was dependent on the maturity of the brain. In rats, the most marked effect was observed 10 to 12 days after birth (Jensen et al. 1991). The reason for this seems to be a developmental change in the composition of the glutamate receptor which increases the neurone's permeability to calcium (Jensen et al. 1995; Jensen 1997). Furthermore, the levels of GABA, one of the most important inhibitory neurotransmitters, in neuronal tissue are very low at this stage of development (Coyle and Enna 1976). In addition, the formation of LTP's (long term potentiations), that play an important role in synaptic plasticity and hence in learning processes, may be disturbed by the induced epileptogenic activity (Bliss et al. 1993). Long-term neurological damage is the inevitable consequence in the children affected.

From a clinical and experimental point of view it is important to subdivide cerebral ischemia in two major forms: (1) global ischemia which is relatively shortlasting and followed by recirculation, and (2) focal ischemia of the stroke type, encompassing a densely ischemic core ('focus') and a less densely ischemic perifocal, penumbra zone (for review: Siesjö et al. 1992). As shown in adult animals epileptogenic impulses in the vicinity of a brain infarct cause a considerable rise in metabolic activity. In an inadequately perfused section of brain tissue such as the penumbra surrounding an infarct, this can rapidly lead to an imbalance between cell metabolism and blood circulation, resulting in brain damage (Heiss and Graf 1994). Cells in the perifocal penumbra are threatened by two events: irregularly occuring ionic transients, and a gradual compromise of the capillary circulation. According to this, focal ischemia differs from global cerebral ischemia in that flow is usually so slow in the focus, and the chances for quick reperfusion so slim that the area will usually become infarcted. Furthermore, the penumbra is usually considered to have flow rates sufficiently high to make the region essentially viable, at least during the first couple of hours (for review: Siesjö et al. 1992). If reperfusion occurs after longer periods, the ischemic focus may be infarcted while the penumbra zone shows either selective neuronal necrosis or areas of infarction

In global cerebral ischemia, such as that caused by cardiac insufficiency, the situation is quite different to that in focal cerebral ischemia. As shown in adult animals it is far less 
clear whether glutamate is directly involved in neuronal cell death (Aitken et al. 1988: Albers et al. 1992). As Hossmannn points out in his 1994 review article, a number of observations argue against any major involvement of glutamate in processes leading to neuronal cell death after global ischemia: (1) Neither the pattern of glutamate release during ischemia nor the cerebral distribution of glutamate receptors matches the regional manifestation of brain damage after global ischemia. (2) Glutamate toxicity in cell cultures from vulnerable brain areas was found to be no higher than in cultures from nonvulnerable regions. (3) in contrast to the effects of in vitro ischemia, application of glutamate to cell cultures or hippocampal tissue slices caused no prolonged inhibition of protein synthesis.

Since then, the possibility of glutamate's playing a key role in the induction of brain damage either during or directly after global ischemia, even in the immature brain, has been effectively excluded by the following observations: Application of glutamate or glutamate antagonists to hippocampal slices from guinea pig fetuses did not affect postischemic protein biosynthesis, a parameter used as an early marker of neuronal celli death (Fig. 4) (Berger et al. 1997c). However, it is possible that later, during the reperfusion phase after cerebral ischemia, glutamate-induced epileptogenic activity does cause brain damage. This possibility will be discussed further on.

\subsection{PROTEIN BIOSYNTHESIS}

As animal experiments show, inhibition of protein synthesis plays a key role in the postischemic processes leading to neuronal cell damage (Hossmann et al. 1992). Protein synthesis is reduced both during ischemia and in the early postischemic phase in vulnerable and non-vulnerable brain areas (Kleihues et al. 1975). At the end of the ischemic period, protein synthesis in non-vulnerable regions recovers to pre-ischemic levels, while in vulnerable regions it remains inhibited (Bodsch et al. 1985). Thus the prolonged inhibition of protein synthesis appears to be an early indicator of subsequent neuronal cell death (Hossmann et al. 1992). This observation ties in with the results of experiments demonstrating the neuroprotective effect of hypothermia or barbiturates after cerebral ischemia (Widmann et al. 1993; Xie et al. 1989). Shortly after cerebral ischemia. the usual inhibition of protein synthesis set in, however, the recovery phase in the normally vulnerable areas was now much shorter, and was accompanied by far less pronounced neuronal cell damage. Similar findings were reported in connection with developmental 

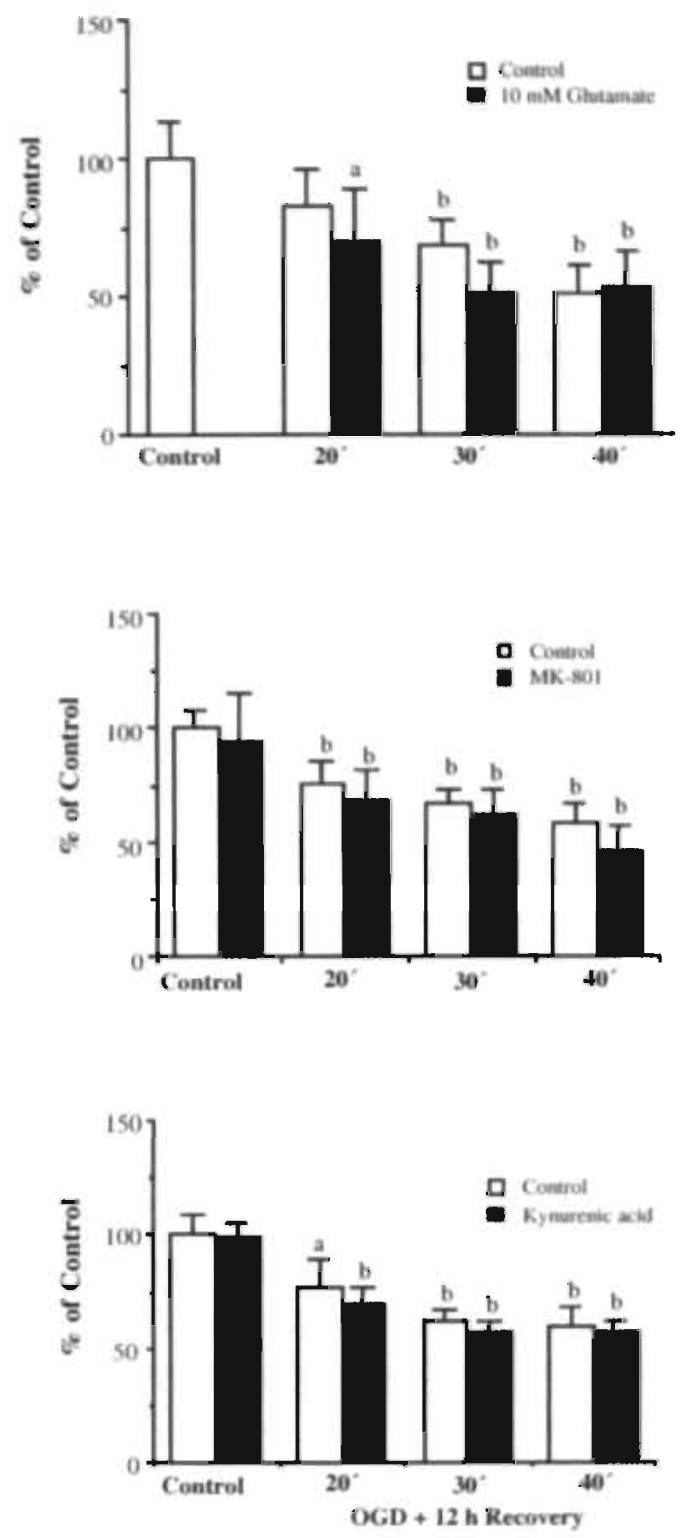

Fig. 4. Protein synthesis rate in hippocampal slices from mature fetal guinea pigs $12 \mathrm{~h}$ after oxygen-glucose deprivation (OGD). The OGD lasted between 20 and $40 \mathrm{~min}\left(20^{\circ}, 30^{\circ}, 40^{\circ}\right)$. Protein synthesis rate was not affected neither by application of glutamate nor by glutamate antagonists (MK-801. Kynurenic acid). Values are given as mean \pm SD. Statistical analysis was preformed by ANOVA followed by Scheffés F-test ta P< $0.05, \mathrm{~b} P<0.01$ (OGD vs. control)) (reproduced with permission. Berger et al. 1997c). 


\section{Chapter 2}

variations in the response of the brain to ischemic insults. Protein synthesis in the fetal brain was found to recover much faster from ischemic insults than that in adult brains (Berger et al. 1996a). The prolonged inhibition of protein synthesis is therefore an early indicator and possibly also one of the causes of neuronal cell damage arising after ischemia (Hossmann et al. 1992).

\subsection{SECONDARY CELL DAMAGE DURING REPERFUSION}

In cerebral tissue capable of regeneration after an ischemic insult, energy metabolism can be seen to recover rapidly (Berger et al. 1996a; Hossmann et al. 1992). A few hours later, however, the energy status is diminished once again in the affected tissue (Blumberg et al. 1997; Penrice et al. 1997). Simultaneously, a secondary cell edema develops, followed a little later by epileptogenic activity that can be monitored on EEG. These events are quite probably brought about or modulated by oxygen radicals, nitric oxide, inflammatory reactions and excitatory amino acids, particularly glutamate.

\section{Oxygen radicals}

During cerebral ischemia, the cut back in oxidative phosphorylation rapidly diminishes reserves of high-energy phosphates. Within a few minutes considerable amounts of adenosine and hypoxanthine accumulate in the cerebrospinal fluid. During reperfusion these metabolic products are metabolised further by xanthine oxidase to produce xanthine and uric acid (de Haan et al. 1993; McCord et al. 1985). Especially, the breakdown of hypoxanthine by xanthine oxidase in the presence of oxygen, produces a flood of superoxide radicals. These are then converted by superoxide dismutase to hydrogen peroxide (Fridovich 1978; 1983). By the Haber-Weiss reaction shown below, hydrogen peroxide and tissue iron can then combine to form hydroxyl radicals.

Numerous studies have shown that oxygen radicals play an important role in processes leading to neuronal cell damage (Traystman et al. 1991: for review: Halliwell et al. 1989). In aduli animals various degrees of neuroprotection against ischemic insults can be achieved through the inhibition of xanthine oxidase or by application of oxygen radical scavengers and iron chelators (Beck et al. 1991; Biegon et al. 1995; Cao et al. 1995; Hall et al. 1991: Lin et al. 1991; Martz et al. 1989; Mink et al. 1991: Patt et al. 1990). Oxygen radicals also appear to be involved in mechanisms underlying neuronal cell death in 
immature animals. The rate of lipid peroxidation was found to be considerably increased after hypoxia in fetal guinea pigs and newborn lambs; (Abdel-Rahman et al. 1995; Goplerud et al. 1992; Mishra and Delivoria-Papadopoulos 1989). The longer the gestational age, the greater this increase was. Furthermore, marked production of oxygen radicals was observed after hypoxia both in vitro, in cultures of fetal neurones, and in vivo, in neonatal mice (Hasegawa et al. 1993; Oillet et al. 1996). There is also evidence that the infarct volume can be reduced in a model of focal ischemia in neonatal rats by application of allopurinol, an inhibitor of xanthine oxidase and oxygen radical scavengers (Palmer et al. 1990).

\section{Nitric oxide}

During cerebral ischemia, a massive influx of intracellular calcium takes place through various channels, regulated, among other things, by the neurotransmitter glutamate (Choi 1992: Siesjö and Bengtsson 1989). The rise in intracellular calcium activates NO-synthase (East and Garthwaite 1991; Garthwaite 1991), which produces NO, citrulline and water from arginine, NADPH and oxygen. There is also an accumulation of cGMP (Beckman et al. 1992). Since there is no oxygen available during ischemia, NO cannot be synthesized until the reperfusion phase.

\section{NO-Synthase}

$$
\text { Arginine }+\mathrm{NADPH}+\mathrm{H}^{*}+\mathrm{O}_{2} \Rightarrow \mathrm{NO}+\text { Citrulline + NADP* + } \mathrm{H}_{2} \mathrm{O}
$$

Likewise, large numbers of superoxide radicals are produced by xanthine oxidase and via other pathways in the mitochondria during and, to an even greater extent, after ischemia (Lynch et al. 1978). During reperfusion, NO and superoxide radicals combine to produce peroxynitrite, leading to the formation of more potent radicals. Destruction of the tissue is the inevitable result (Beckman et al. 1992).

Investigations of the action of inhibitors of NO-synthase in models of cerebral ischemia in adult animals have yielded highly variable results (Caldwell et al. 1994; Dalkara et al. 1994: Dawson et al. 1994; Hamada et al. 1995; Kuluz et al. 1993; Nagafiji et al. 1993; Nishikawa et al. 1993: Zhang et al. 1994). This can be explained by the fact that the neuroprotective effect of NO-synthase blockers after ischemia, that is brought about by a lowering of NO production and consequent reduction of the build-up of potent radicals, is counteracted by a marked vasoconstriction induced by the fall in NO concentration in 
endothelial cells (Dambska et al. 1989). Thus Moskowitz and co-workers found markedly smaller infarct loci after occlusion of the A. cerebri media in mice whose expression of the neuronal form of NO-synthase had been blocked than in the wild type of the animal (Huang et al. 1994). The same group was also able to protect the brain from ischemic insults by application of selective blockers of neuronal NO-synthase (Dambska et al. 1989).

To date hardly any studies have investigated the importance of nitric oxide in neuronal cell death in neonates or fetuses. After a hypoxic-ischemic insult in neonatal rats, a greater number of neurones were found to contain NO-synthase (Higuchi et al. 1996). The activity of this NO-synthase, however, appeared to be diminished (Jensen 1997). Furthermore, two peaks of $\mathrm{NO}$ production were detected in this animal model: one during hypoxia and the other one during the reoxygenation period. The neuronal and the inducible form of NOsynthase seems to be differently involved in this process (Higuchi et al. 1998). Some authors succeeded in preventing ischemic lesions in the brains of immature animals through application of NO-blockers (Ashwal et al. 1984; Hamada et al. 1994; Trifiletti et al. 1992), while other research teams were unable to achieve this effect or observed. instead, a worsening of the damage (Marks et al. 1996: Spanggord et al. 1996). As already mentioned, this discrepancy may have arisen from the different effects of NO-blockers on vascular endothelia and neurones. In our investigations of the effect of blocking NOsynthase we therefore by-passed the cardiovascular system, by carrying out experiments on hippocampal slices (Berger et al. 1998b). Although postischemic NO-production could be completely blocked with NO-inhibitors, this intervention had no influence on the postischemic inhibition of protein biosynthesis, a parameter used as an early indicator of neuronal cell death. Whether or not NO is directly involved in the pathogenesis of neuronal cell death following ischemia in fetuses therefore remains an open question.

\section{Glutamate}

Williams and co-workers: observed epileptiform activity in mature sheep fetuses about 8 hours after $30 \mathrm{~min}$ of global cerebrai ischemia that reached a peak 10 hours after the ischemic period (Williams et al. 1991). They were able to completely inhibit this epileptiform activity by application of the glutamate antagonist MK-801, and show that the resulting brain damage was markedly reduced in the treated animals (Tan et al. 1992). This suggests that a secondary wave of glutamate release or an imbalance between excitatory and inhibitory neurotransmitters during reperfusion may induce epileptiform bursts of neuronal activity that can lead to an uncoupling of cell metabolism and blood flow. This would automatically impair pathways of energy metabolism and cause a secondary wave 
of cell damage (Hossmann 1994).

\subsection{INFECTION RELATED CEREBRAL INJURY}

As demonstrated by a variety of recent studies, inflammatory reactions not only aggravate secondary neuronal damage after cerebral ischemia, but may also affect the immature brain directly. Thus, after chorioamnionitis the incidence of immature babies suffering from periventricular leucomalacia and peri- or intraventricular hemorrhage is significantly increased (Berger et al. 1997; Jensen et al. 1992; Yoon et al. 2000; Wu and Colford 2000). However, it remains unclear whether fetal brain damage following endotoxemia is the result of cerebral hypoperfusion caused by circulatory decentralization or whether it is caused by a direct effect of endotoxins on cerebral tissue (for review: Dammann and Leviton 1997).

The effects of sytemically applied lipopolysaccharides (LPS) on circulatory responses were studied in chronically instrumented immature fetal sheep (0.7 of gestation) (Fig. 5) (Garnier et al. 2001). Within I h after i.v. injection of LPS ( $E$. coli; $53 \pm 3 \mu \mathrm{g}$ per $\mathrm{kg}$ fetal weight) there was a marked fall in arterial oxygen saturation $(-46 \%)$ and $\mathrm{pH}(7.36 \pm 0.03 \mathrm{vs}$. $7.16 \pm 0.11$ ). Whereas blood flow to the placenta severely decreased, that to the carcass rose. During a short period of superimposed intrauterine asphyxia circulatory dezentralization occured. During the immediate recovery period oxygen delivery to the cerebrum was minimal. It is obvious that under such circumstances fetal hypoxic-ischemic brain injury may occur.

Recently, we studied the effects of very low doses of LPS ( $E$. coli; $100 \mathrm{ng} / \mathrm{kg}$ fetal BW) on fetal cardiovascular function and resulting neuropathology. Systemically administered LPS caused a substantial and longlasting decrease in umbilical blood flow resulting in sustained fetal hypoxemia without acidemia (Garnier et al. 2002). FHR and MAP increased at 4-5 hrs after LPS and was elevated during 15 hrs after LPS. Placental blood flow began to fall $1 \mathrm{hr}$ after LPS and was minimal $(-30 \%)$ at 4-5 hours after LPS, while placental vascular resistance rose by $70 \%$ during this period. Thereafter, placental blood flow slowly returned to control values at 12-16 hrs after LPS. Histological examination revealed groups of inflammatory cell infiltrations in the periventricular white matter in L.PS treated fetuses. On electronmicroscopical evaluation these cells appeared to be polymorphonuclear leukocytes (neutrophils: PMNs) and activated microglia. Moreover, an increased rate of apoptotic cells was detected after LPS treatment in the periventricular white matter. 

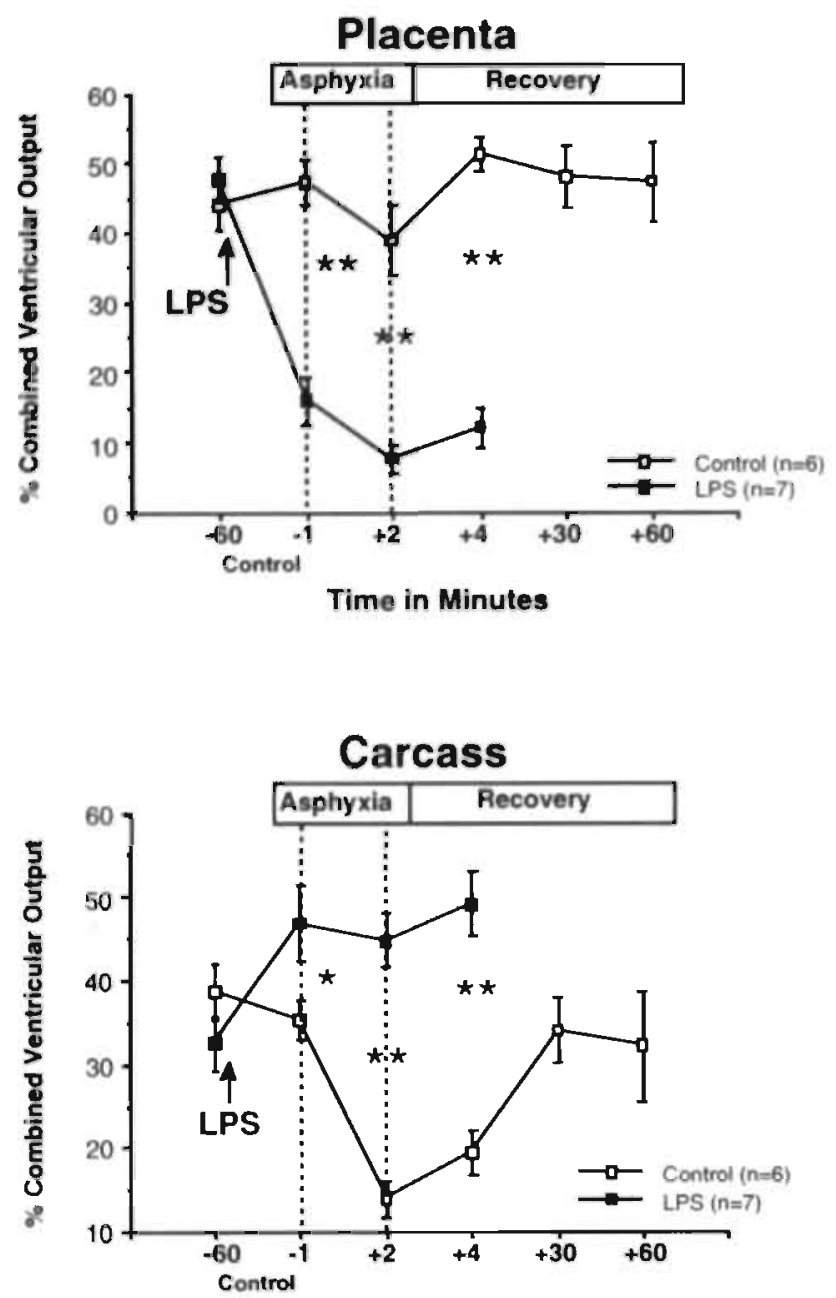

Time in Minutes

Figure 5. Combined ventricular outpur directed to the placenta and carcass in control $(n=6)$ and LPS treated (n = 7) chronically catheterized immature fetal sheep ( 0.7 of gestation) before, during and after arrest of uterine blood flow for $2 \mathrm{~min}$. In LPS treated fetuses there was a significant fall in the percentage of combined ventricular output directed to the placenta while that directed to the carcass significantly increased. This was not seen in controls. During arrest of uterine blood flow the portion distributed to the carcass remained elevated in fetuses of the study group (P<0.001). Within $60 \mathrm{~min}$ after induction of asphyxia 5 out of 7 LPS treated fetuses died, whereas control fetuses completely recovered during this period. Values are given as means \pm SEM. The data were analysed within and between groups using a two-way ANOVA followed by Ganies-Howell post-hoc test ("P<0.05. ${ }^{*} \mathrm{P}<0.01$ ) (Garnier et al. 2001) 
PMNs are blood-born inflammatory cells with potent oxidative and proteolytic potential that are usually the first line of defense against invading pathogens. Their ability to exit blood vessels and migrate rapidly to extravascular sites in tissues is crucial for succesfull elimination of bacterial, parasitic, and viral infections (for review: Wagner and Roth, 1999). Activation of PMNs is frequenttly implicated in the promulgation of deleterious inflammatory processes, including tissue injury associated with exposure to endotoxin.

The direct cytotoxic effect of LPS in vivo was examined in a neonatal rat model. Rat pups were subjected to an hypoxic-ischemic insult using a combination of a common carotid artery ligation (Levine model) and hypoxic exposure for $60 \mathrm{~min}$. One hour before the insult the rats received either $\mathrm{NaCl}$ or $5 \mu \mathrm{g}$ LPS into the cisterna magna. LPS significantly increased the resulting neuronal cell damage in the cerebral cortex (Coumans et al. 2002).

\subsection{APOPTOSIS AND POSTISCHEMIC GENOME EXPRESSION}

It is still unclear whether secondary cell death after ischemia is necrotic or apoptotic. The latter condition is characterised by a shrinking of the cell, blebbing of the cell membrane, condensation of chromatin and DNA fragmentation induced by a calcium-dependent endonuclease (Fig. 6) (Busciglio et al. 1995). In DNA electrophoresis this fragmentation can be recognised by a typical DNA ladder (McManus et al. 1993).

In neuronal cell cultures, apoptosis can be prevented by postischemic inhibition of protein synthesis using cycloheximide, or inhibition of RNA synthesis with actinomycin or through inhibition of endonuclease with aurin tricarboxylic acid. In addition, the amount of apoptotic cell death was reduced by inhibition of caspases in neonatal rats after a hypoxicischemic insult (Cheng et al. 1998). These findings all point towards the existence of a built-in cellular suicide programme (Ratan et al. 1994; Rosenbaum et al. 1994). It is also possible that the form of secondary cell death following ischemia is determined by the severity of the primary insult. Thus. Dragunow and co-worker were able to demonstrate that delayed cell death in immature rat brains subjected to a 15-min period of hypoxicischemia was of an apoptotic nature, while after a 60 -min insult the neuronal damage was predominantly necrotic (Dragunow et al. 1994). Other investigators have also reported correlations between the severity of the insult and the extent of apoptotic cell death (Li et al. 1995; Mehmet et al. 1994)。

As has been shown in numerous studies, including some on immature animals, cerebral 
ischemia can induce the expression of a whole series of proto-oncogenes (Blumenfeld et al. 1992; Ferriero et al. 1990; Munell et al. 1994). Proto-oncogenes themselves code for proteins that act as transscription factors and regulate the expression of genes modulating cell growth and differentiation. They are also termed 'immediate early genes' since they are expressed within a few minutes of an insult. These include c-fos, c-jun, jun-B, jun-D. The transscriptional activity of proteins of the fos-family is caused by a heterodimer formation with proteins of the jun-family (Longo et al. 1997). Fos- and jun-proteins can also form dimers with proteins of the ATF- and CREB families and thereby increase their promotor affinity (Hai and Curran 1991).

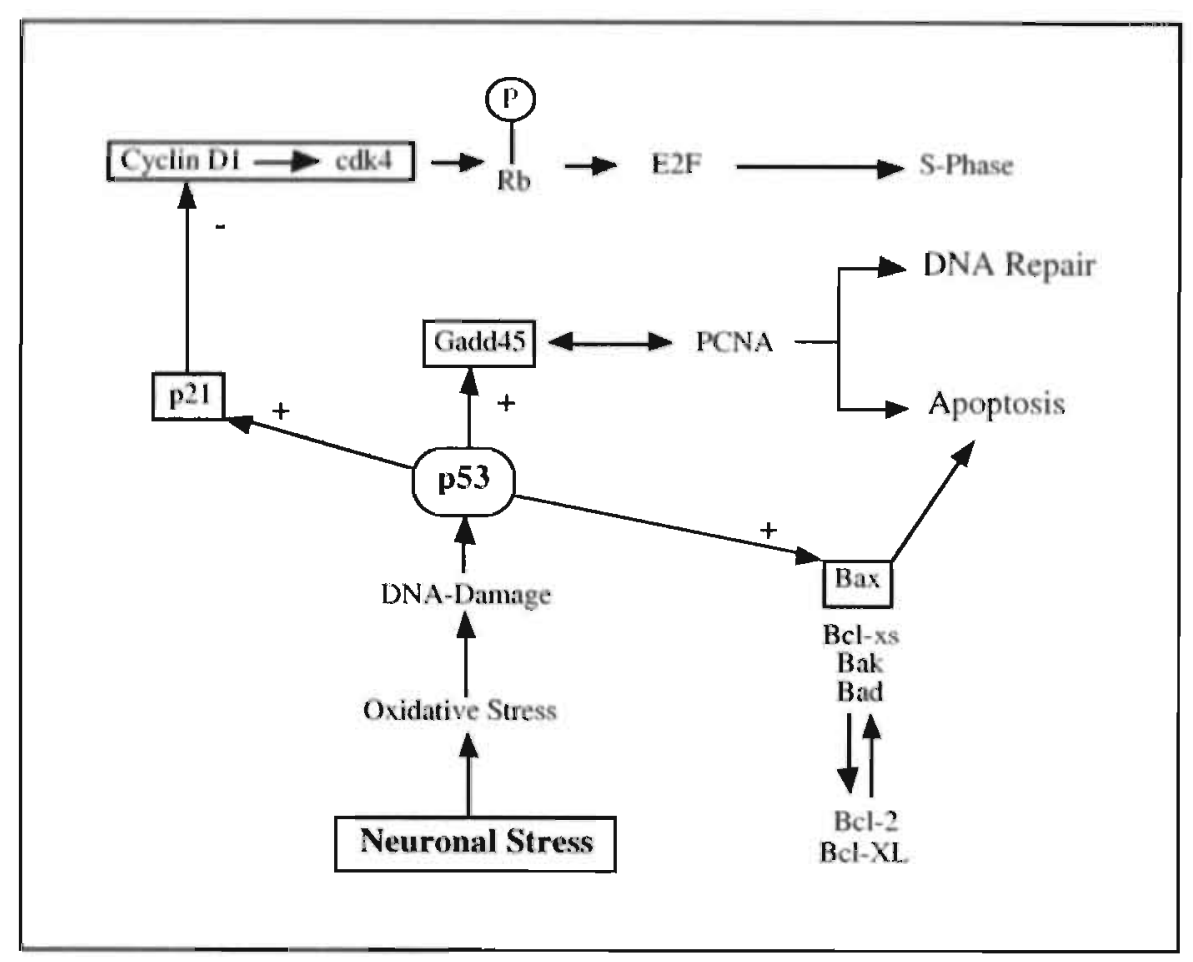

Figure 6. Diagramm illustrating the central role of p53 in mediating DNA repair or apoptosis in neurons during and after cerebral ischemia (modified after Khrestchatisky et al. 1996). Gadd45, growth-arrest-andDNA-damage-inducible: cdk4, cyclin D-dependent kinase; for further abbreviations see text.

As already mentioned, transscription factors control the expression of genes participating 
in cell growth and differentiation. Depending on the severity of the insult, these factors are therefore capable of initiating processes leading to apoptotic cell death or triggering a recovery programme. Recent research findings have indicated that the proto-oncogenes and cell cycle-dependent proteins such as cyclin Dl (Timsit et al. 1996; Wiessner et al. 1996), and tumor suppressor genes such as p53 are critically involved in this control function.

Depending upon the developmental stage of the injured brain and the extent of cell damage on the one hand, and upon damage-induced p53 expression on the other, neurons may attempt cell cycle entry, a process that will involve a certain amount of DNA repair, or may only attempt transscription-coupled DNA repair. The cell death decision may result from the impossibility to proceed with both processes. Indeed, it has recently been shown in vitro that the p53 transscription factor, besides its role in halting replication while favoring repair, attenuates Bcl-2 expression, and is a direct transscriptional activator of the Bax gene, whose product is shown to induce apoptosis (Miyashita et al. 1994; for review: Reed et al. 1994).

\subsection{PERINATAL NEUROPROTECTION}

Despite the critical clinical and socio-economic consequences of perinatal brain damage, no effective therapeutic strategies have yet been developed. However, as already mentioned, some promising possibilities have been revealed through animal experiments that could be developed and tested in clinical studies. As discussed in the sections above, the cascade of subsequent events to neuronal death involves accumulation of cytosolic calcium and activation of a variety of calcium-mediated deleterious events, including generation of free radicals. It is important to note that this cascade of events leading to neuronal and oligodendroglial death occur over hours after termination of the hypxicischemic insult. The exciting implication concerning therapeutic management is that interruption of this deleterious cascade even after termination of the insult could prevent or ameliorate the brain injury in hypoxic-ischemic disease (for review: Berger and Garnier 1999; Vanucci and Perlman 1997: Volpe 200I). In the following sections, current therapeutic concepts. will be described by which neuroprotection has been achieved in animal models. 


\subsubsection{PHARMACOLOGICAL INTERVENTION}

Now that the pathophysiological mechanisms underlying neuronal cell damage are better understood, diverse possibilities present themselves for pharmacological intervention. Interest is currently focused on the administration of oxygen radical scavengers, NO inhibitors, glutamate antagonists, calcium antagonists, growth factors and anticytokines. Table 2 presents potential neuroprotective drugs currently under investigation (modified according to Tuor et al. 1996).

\section{Flunarizine}

In experimental animal models of focal and global cerebral ischemia, flunarizine, a class IV calcium channel blocker, has shown to be neuroprotective when given before, but not after, the insult (Van Reempts et al. 1983: Silverstein et al. 1986: Gunn et al. 1989; Chumas et al. 1993; Gunn et al. 1994). In some of these studies flunarizine was applied at relatively high doses (i.e., $30 \mathrm{mg} / \mathrm{kg}$ body weight) before hypoxia. İpsilateral infarction of the brain after ligation of one carotid artery could be almost totally prevented in animals receiving such treatment (Van Reempts et al. 1983; Silverstein et al. 1986; Gunn et al. 1989; Chumas et al. 1993). Similar results have been described by Gunn and co-workers (1994) in a fetal sheep model. However, the high dose regimens used by these authors had severe cardiovascular side-effects. In a low dose treatment protocol (flunarizine, $0.5 \mathrm{mg} / \mathrm{kg}$ fetal body weight), de Haan and co-workers (1993) found no significant changes in regional cerebral blood flow in severely asphyxiated fetal sheep.

\section{Lubeluzole}

Lubeluzole, the S-isomer of a novei 3,4-difluoro benzothiazole, has been shown to reduce ischemic neuronal cell damage in a variety of in vitro as well as in vivo studies. The neuroprotective property of lubeluzole may result from various effects on neuronal tissue. First, lubeluzole has been shown to block ischemia-induced increases in extracellular levels of glutamate and may therefore reduce excitotoxic cell injury (Scheller et al. 1997). Second, lubeluzole inhibits glutamate-stimulated nitric oxide production (Lesage et al. 1996). Nitric oxide combines with superoxide anions to synthesize peroxynitrite, a compound that spontaneously decomposes to form hydroxyl radicals, nitrogen dioxide and $\mathrm{NO}^{2+}$. All these radicals are able to destroy cell membranes and various intracellular structures. Third, lubeluzole has been shown to activate voltage-sensitive $\mathrm{Ca}^{2 *}$ channels in isolated rat dorsal root ganglion cells thus possibly reducing the tremendous intracellular 
Table 2: Pharmacologicall Intervention on Hypoxic-Ischemic Brain Damage in Various Models of Hypoxia-Ischemia (modified after Tuor et al. 1996)

\begin{tabular}{|c|c|c|c|c|c|c|}
\hline Treatment class & Treatment details & Age/species & $\begin{array}{l}\text { Hypoxie/ischemic } \\
\text { insult }\end{array}$ & $\begin{array}{l}\text { Time of } \\
\text { treatment with } \\
\text { respect to insult }\end{array}$ & $\begin{array}{l}\text { Neuro- } \\
\text { protection/ } \\
\text { pathology }\end{array}$ & Reference \\
\hline \multirow{7}{*}{$\begin{array}{l}\text { YSCC's } \\
\text { anatgonists }\end{array}$} & Flunarizine $(30 \mathrm{mg} / \mathrm{kg})$ & 7 days $/ \mathrm{rat}$ & $\mathrm{UCO}+2 \mathrm{~h} 8 \% \mathrm{O}_{2}$ & pre & partial & Silverstein et al. 1986 \\
\hline & Flunarizine (30mg/kg) & 7 days / rat & $\mathrm{UCO}+3 \mathrm{~h} 85 \mathrm{O}_{3}$ & pre & partial & Chumas et al 1993 \\
\hline & Flunarizine $(30 \mathrm{mg} / \mathrm{kg})$ & 21 days / rat & $\mathrm{UCO}+2 \mathrm{~h} 8 \% \mathrm{O}$ & pre & partial & Gunn et al. 1989 \\
\hline & Flunarizine (9mg/kg) & fetal sheep & $30 \min \mathrm{BCO}(+\mathrm{VOAO})$ & pre & partial. & Gunn et al, 1994 \\
\hline & Flunarizine (1mg/kg) & fetal sheep & $30 \mathrm{Min} \cdot \mathrm{BCO}(+\mathrm{VOAO})$ & pre & partial & Berger et al. 1998 . \\
\hline & $\begin{array}{l}\text { Nimodipine }(70 \mu \mathrm{g} / \mathrm{kg} \text { or } \\
0.5 \mathrm{mg} / \mathrm{kg})\end{array}$ & 7 days $/$ rat & $\mathrm{UCO}+3 \mathrm{~h} 8 \% \mathrm{O}_{2}$ & pre & no effect & Chumas et al. 1993 \\
\hline & Nimodipine $(0,5 \mathrm{mg} / \mathrm{kg})$ & $0-3$ days $/$ pig & $\begin{array}{l}30 \text { min } \mathrm{BCO}+\text { hypotonia } \\
\text { \& } 15 \text { min } 6 \% \mathrm{O}_{2}\end{array}$ & post & no effect. & Le Blanc et al. 1991 \\
\hline \multirow{7}{*}{$\begin{array}{l}\text { NMDA } \\
\text { anatgonist }\end{array}$} & MK-801 (10mg/kg) & 7 days / rat & $\mathrm{BCO}+1 \mathrm{~h} 8 \% \mathrm{O}_{2}$ & pre & total & Hattori et al. 1989 \\
\hline & MK-801 (10mg/kg) & 7 days / rat & $\mathrm{BCO}+1 \mathrm{~h} 8 \% \mathrm{O}_{1}$ & post & partial & Hantori et al. 1989 \\
\hline & MK-80I ( $1 \mathrm{mg} / \mathrm{kg})$ & 7 days / rat & $\mathrm{UCO}+3 \mathrm{~h} 85 \%$ & pre, intra & partial & MeDonald et al. 1987 \\
\hline & MK-801 (10mg/kg) & $7 \mathrm{days} / \mathrm{rat}$ & $\mathrm{UCO}+2 \mathrm{~h} 8 \% \mathrm{O}_{1}$ & pre, intra & partial & Ford et al. 1989 \\
\hline & $\begin{array}{l}\text { MK-801 (0.3 brw. } \\
0.5 \mathrm{mg} / \mathrm{kg})\end{array}$ & 7 days / rat & $\mathrm{UCO}+1.5 \mathrm{~h} 7.65 \mathrm{O}_{3}$ & post $(0 \mathrm{~h})$ & partial & Hagberg et al. 1994 \\
\hline & MK-s01 (0.75mg/kg) & 7 days / tal & $\mathrm{UCO}+1.5 \mathrm{\&} 7,6 \% \mathrm{O}$ & post $(0 \mathrm{~h})$ & no effect & Hageberg et al. 1994 \\
\hline & MK-801 (3teng/kg) & 0.3 days $t$ pig & $\begin{array}{l}30 \text { min } B C O+\text { hypotonia } \\
\text { \& } 15 \text { min } 6 \% \mathrm{O}_{2}\end{array}$ & post $(0 \mathrm{~h})$ & no efflect & Le Blanc et al. 1991 \\
\hline
\end{tabular}


Table 2: continued...

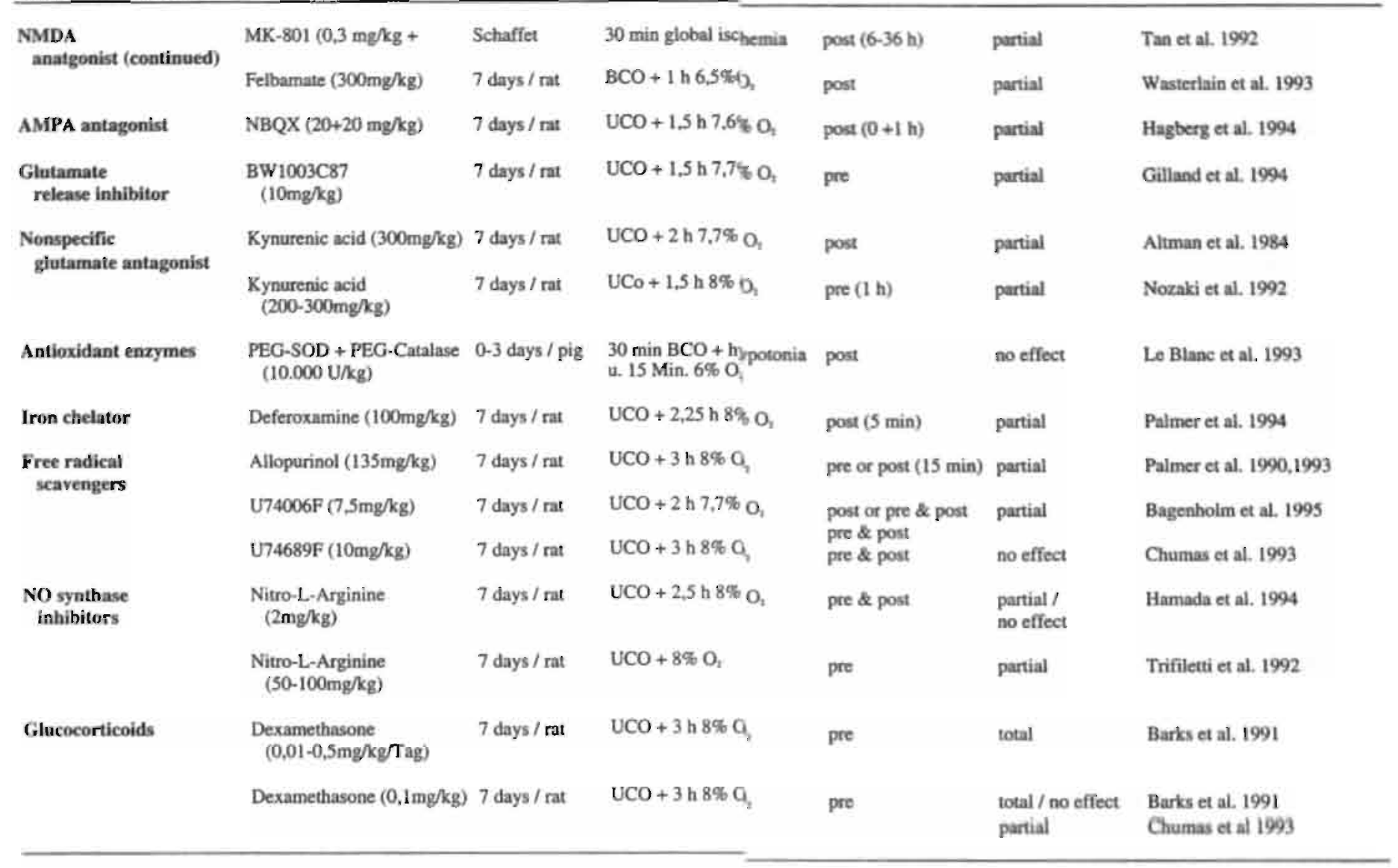


Table 2: continued.

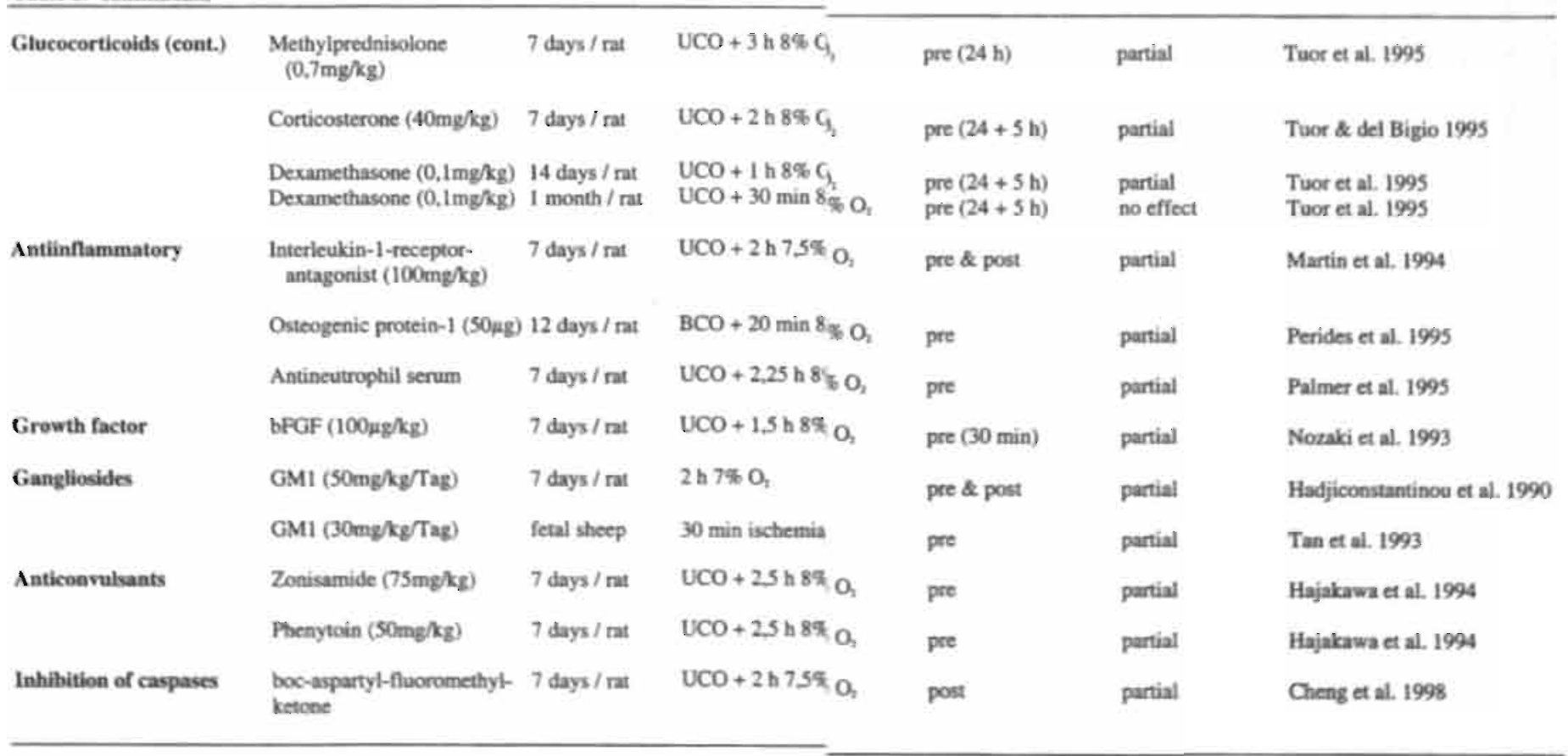

UCO: unilateral ooclusion of carotid arteries, BCO: bilateral occluasion of carotid arteries, VOAO: ocelusion of the vertebro-occipital anastomoses,

BP: arterial blood pressure, BFGF; basic fibroblast growth factor 
influx of this ion during an ischemic insult (Marannes and De Prins 2000). This so-called calcium overload leads to cell damage by activating proteases, lipases and endonucleases (Siesjö and Bengtsson 1989). Fourth, lubeluzole decreased DNA fragmentation and annexin-V binding in primary hippocampal neurons (Maiese and Vincent 2000a,b). Since these two phenomena are specific markers of apoptosis, lubeluzole might protect neurons from ischemic injury through its inhibitory effects on pathophysiological pathways that trigger the cellular suicide programme. However, these last three lubeluzole-mediated effects have so far only been observed in neuronal tissue in vitro. Their in vivo significance has still to be confirmed.

\section{Magnesium}

In the clinical setting, $\mathrm{MgSO}_{4}$ has been used widely in obstetric practice for over 60 years. A retrospective epidemiologic study by Nelson and Grether (1995) suggested that premature fetuses whose mothers received $\mathrm{MgSO}_{4}$ for the treatment of preeclampsia or as a tocolytic agent are less likely to develop cerebral palsy compared to gestational age-matched group of fetuses not exposed to the drug. Almost identical results were recently obtained in a retrospective study carried out by Schendel and co-workers (Schendel et al. 1996).

Magnesium is a naturaliy occurring NMDA receptor antagonist that blocks the neuronal' influx of $\mathrm{Ca}^{2+}$ within the ion channel (McDonald et al. 1990). Experimental studies in newborn animals have shown a neuroprotective effect of magnesium sulfate $\left(\mathrm{MgSO}_{4}\right)$. $\mathrm{MgSO}_{4}$ reduced brain injury in 7-day old rats when administered 15 minutes after cerebral injection of NMDA (McDonald et al. 1990). However, experimental studies on application of magnesium in various perinatal models of cerebral hypoxia/ischemia have as yet been. inconclusive. While a variety of investigations have shown clear neuroprotective effects of magnesium (Altura and Altura 1981; Choi 1990; Hallak et al. 2000; Hoffman et al. 1994: Maulik et al. 1999; Mishra and Delivoria-Papadopoulos 1992: Nowak 1984; Sameshima et. al. 1999; Thordstein et al. 1993), this could not be confirmed by others (de Haan et al. 1997: Penrice et al. 1997). Postischemic treatment in particular was seen to be ineffective or even to widen the extent of the resulting damage in the neonatal rat model (Levinemodel) (Sameshima et al. 1999). As already discussed by Sameshima and co-workers this exacerbation of ischemic damage may arise from magnesium-induced hypotension (Sameshima et al. 1999). Using the same animal model Vanucci and Ringel reported' almost complete ischemia in the ipsilateral brain hemisphere during $2 \mathrm{~h}$ of hypoxia (Ringel et al. 1991: Vanucci et al. 1998). Although they did not measure regional blood flow after hypoxia-ischemia, reperfusion to the brain hemisphere could possibly occur during an 
early stage of recovery. Since magnesium can alter vascular tone by blocking neuromuscular junctions, treatment with magnesium after ischemia may quantitatively change blood flow to brain regions during the reperfusion period and result in more severe brain damage.

\subsubsection{PHYSIOLOGICAL INTERVENTION}

\section{Hypothermia}

The induction of mild hypothermia has raised interesting possibilities for neuroprotection from cerebral ischemia (for review: Maher and Hachinski 1993). Various publications dating back to the 1950s, have described the therapeutic benefits of hypothermia in brains subjected to a wide variety of insults including brain trauma (Parkhouse 1957; Sedzimir 1959), cerebral haemorrhage (Howell et al. 1956), cardiac arrest (Benson et al. 1959), carbon monoxide poisoning (Craig et al. 1959), neonatal asphyxia (Westin et al. 1959) and seizures (Brown and McGarry 1961). Based on these findings, routine induciion of hypothermia was introduced early on in heart and brain surgery to protect the brain in the event of iatrogenic intraoperative cardiac arrest (Boterell et al. 1956; Drake et al. 1964; Lewis and Taufic 1953; Lougheed et al. 1955; Negrin 1961). Over the last few years, induction of mild hypothermia has been examined once again as a means of protecting the brain from ischemically induced damage. Experimental studies on adult animals have shown that lowering of the brain temperature by $3-4^{\circ} \mathrm{C}$ during global cerebral ischemia reduces neuronal cell damage dramatically (Busto et al. 1987; Coimbra et al. 1994; Green et al. 1992: Welsh et al. 1990; Widmann et al. 1993). Furthermore, the treated animals were found to perform better than controls in subsequent learning and behavioural tests (Green et al. 1992).

In hippocampal slices from mature guinea pig fetuses induction of mild hypothermia considerably improved the postischemic recovery of protein synthesis and energy metabolism (Berger et al. 1996b; 1998a). In a recently published study, Gunn and coworkers described the effects of moderate hypothermia in sheep fetuses subjected to severe global cerebral ischemia in utero (Gunn et ạl. 1997). Hypothermia was initiated during the reperfusion phase, $90 \mathrm{~min}$ after induction of $30 \mathrm{mins}$ of ischemia, in a 4-vessel occulusion model, and maintained for 72 hours. By this method it was possible to reduce the extent of neuronal cell damage in areas of the cortex cerebri by up to $60 \%$ (Gunn et al. 1997). Even if hypothermia was started not before several hours after ischemia, neuroprotection could be observed in various animal model (Gunn et al. 1998). Based on these results, many 
authors now consider the induction of hypothermia during and particularly after a hpoxicischemic insult to be an effective therapeutic strategy (Busto et al. 1989; Gunn et al 1997). In fact, recent clinical safety studies have demonstrated that induction of mild hyporermia in newborn infants after perinatal asphyxia has no harmful side-effects (Gunn et a 1998: Azzopardi et al. 2000).

\subsection{REFERENCES}

1. Abdei-Rahman A, Parks JK, Deveraux MW, Sokol RJ, ParkerJr WD, Rosnberg AA: Developmental changes in newborn lamb brain, mitochondrial activy and postasphyxial lipid peroxodation. PSEBM 209 (1995) 170-177

2. Aitken PG, Balestrino M, Somje GG: NMDA antagonists: Lack of protectivieffect against hypoxic damage in CAI region of hippocampal slices. Neurosci ett 89 (1988) $187-192$

3. Albers GW. Goldberg MP. Choi DW: Do NMDA antagonists prevent nuronal injury? Arch Neurol 49 (1992) 418-420

4. Altman DI, Young RSK. Yagel SK: Effects of dexamethasone in hypoxic/ischemic brain injury in the neonatal rat. Biol Neonate (1984) 149.56

5. Altura BM, Altura BT. Magnesium ions and contraction of vascular smooth muscles: relationship to some vascular diseases. Fed Proc 40 ( 1981 ) 2672-79

6. Andine P, Lehmann A, Ellren K, Wennberg E. Kjellmer I, Nielsen T, Hagberg H The excitatory amino acid antagonist kynurenic acid administered after hypoxic ischemia in neonatal rat offers neuroprotection. Neurosci Lett 90 (1988) 208-212

7. Ashwal S, Dale PS, Longo LD: Regional cerebral blood flow: Studies in the feta lamb during hypoxia, hypercapnia, acidosis, and hypotension. Pediatr Res 18 (1984 1309.1316

8. Ashwal S, Cole DJ, Osborne S, Osborne TN, Pearce WJ; L-NAME reduces infarc volume in a filament model of transient middle cerebral artery occlusion in the rat pup. Pediatr Res 38 (1995) 652-656

9. Azzopardi D, Robertson NJ, Cowan FM, Rutherford MA, Rampling M, Edwards AD. Pilot study of treatment with whole body hypothermia for neonatal encephalopathy. Pediatrics 106 (2000) 684-694

10. Bagenholm R. Andine P. Hagberg H, Kjellmer I: Effects of 21-aminosteroid U74006F on brain damage and edema in following perinatal hypoxia/ischemia in the rat. J Cereb Blood Flow Metab 15 (1995) 134

11. Banker BQ. Larroche JC: Periventricular leukomalacia of infancy. Arch Neurol (1962) $386-410$

12. Barks JDE, Post M, Tuor UI: Dexamethasone prevents hypoxic/ ischemic brain 
damage in the neonatal rat. Pediatr Res 29 (1991) 558-563

13. Barmada MA. Moossy J, Shuman RM: Cerebral infarcts with arteriall occlusion in neonates. Ann Neurol 6 (1979) 495-502

14. Beck T, Bielenberg GW: The effects of two 21-aminosteroids on overt infarct size 48 hours after middle cerebral artery occlusion in the rat. Brain Res 560 (1991) 159-162

15. Beckman JS, Chen J, Ischiropoulos $\mathrm{H}$, Conger KA: Inhibition of nitric oxide synthesis and cerebral protection. Krieglstein J, Oberpichler-Schwenk H (eds.). Pharmacology of cerebral ischemia, Wissenschaftliche Verlasggesellschaft mbH, Stuttgart (1992) 383-394

16. Bejar R, Vigliocco G, Gramajo H, Solana. C, Benirschke K, Berry C, Coen R: Antenatal origin of neurologic damage in newborn infants II. Multiple gestations. Am J. Obstet Gynecol 162 (1990) 1230-1236

17. Benveniste H. Dreje J. Schousboe A. Diemer NM: Elevation of the extracellular concentrations of glutamate and aspartate in rat hippocampus during transient cerebral ischemia monitored by intracerebral microdialysis. J Neurochem 43 (1984) 1369-1374

18. Benson DW, Williams GR, Spencer FC, Yates E: The use of hypothermia after cardiac arrest. Anesth Analg 38 (1959) 423-428

19. Berger R, Bender S, Sefkow S, Klingmüller V, Künzel W, Jensen A: Peri/intraventricular haemorrhage: a cranial ultrasound study on 5286 neonates. Eur J Obstet Gynecol Reprod Biol 75 (1997a) 191-203

20. Berger R, Garnier Y: Pathophysiology of perinatal brain damage. Brain Res Brain Res Rev 30 (1999) 107-134

21. Berger R, Garnier Y, Pfeiffer D, Jensen A: Lipopolysaccharides do not alter metabolic disturbances in hippocampal slices of fetal guinea pigs after oxygenglucose deprivation. Pediatr Res 48 (2001) 531-535

22. Berger R, Djuricic B, Jensen A, Hossmann KA, Paschen W: Ontogenetic differences in energy metabolism and inhibition of protein synthesis in hippocampal slices during in vitro ischemia and $24 \mathrm{~h}$ of recovery. Dev Brain Res 9 (1996a) 281-29I

23. Berger R, Djuricic B, Jensen A, Hossmann KA, Paschen W: Mild hypothermia provides neuroprotection in an in vitro model of fetal cerebral ischemia. J Soc Gynecol Invest 3 (1996b) 391

24. Berger R, Gjedde A, Hargarte L, Hargarter S, J Krieglstein J, Jensen A: Regional cerebral glucose utilization in immature fetal guinea pigs during maternal isocapnic hypoxemia. Pediatr Res 42 (1997b) $311-316$

25. Berger R, Gjedde A, Heck J, Müller E, Krieglstein J, Jensen A: Extension of the 2deoxyglucose method to the fetus in utero: Theory and normal values for the cerebral glucose consumption in fetal guinea pigs. J Neurochem 63 (1994) 271-279

26. Berger R, Jensen A, Krieglstein J, Steigelman JP: Effects of acute asphyxia on brain energy metabolism in fetal guinea pigs near term. J Dev Physiol I6 (1991) 9-11

27. Berger R, Jensen A. Krieglstein J, Steigelman JP: Cerebral energy metabolism in 
immature and mature guinea pig fetuses during acute asphyxia. J Dev Physiol 18 (1992) $125-128$

28. Berger R, Jensen A, Krieglstein J, Steigelmann JP: Cerebral energy metabolism in fetal guinea pigs during moderate maternal hypoxemia at 0.75 of gestation. J Dev Physiol 19 (1993) 193-196

29. Berger R, Jensen A, Hossmann KA, Paschen W: No effect of glutamate on metabolic disturbances in hippocampal slices of mature fetal guinea pigs after transient in vitro ischemia. Dev Brain Res 101 (1997c) 49-56

30. Berger R, Jensen A, Hossmann KA, Paschen W: Effect of mild hypothermia during and after transient in vitro ischemia on metabolic disturbances in hippocampal slices at different stages of development. Dev Brain Res 105 (1998a) 67-77

31. Berger R, Jensen A, Paschen W: Metabolic disturbances in hippocampal slices of fetal guinea pigs during and after oxygen-glucose deprivation: Is nitric oxide involved? Neurosci Lett 245 (1998b) 163-166.

32. Berger R, Lehmann T, Karcher J, Schachenmayr W, Jensen A: Relation between cerebral oxygen delivery and neuronal cell damage in fetal sheep near term. Reprod Fertil Dev 8 (1996c) 317-321

33. Biegon A, Joseph AB: Development of HU-2II as a neuroprotectant for ischemic brain damage. Neurol Res 17 (1995) 275-280

34. Bliss TVP, Collingridge GL: A synapic model of memory: Long term potentiation in the hippocampus. Nature 361 (1993) 31-39

35. Blumberg RM, Cady EB, Wigglesworth JS, McKenzie JE, Edwards AD: Relation between delayed impairment of cerebral energy metabolism and infarction following transient focal hypoxia-ischaemia in the developing brain. Exp Brain Res 113 (1997) $130-137$

36. Blumenfeld KS, Welsh FA, Harris VA, Pesenson MA: Regional expression of c-fos and heat shock protein-70 mRNA following hypoxia-ischemia in immature rat brain. J Cereb Blood Flow Metab 12 (1992) 987-995

37. Bodsch W, Takahashi K, Barbier A, Grosse Ophoff B, Hossmann KA: Cerebral protein synthesis and ischemia. Prog Brain Res 63 (1985) 197-210

38. Boterell EH, Lougheed WM, Scoll JW, Vandewater SL: Hypothermia, and. interruption of carotid, or carotid and vertebral circulation, in the surgical management of intracranial aneurysms. J Neurosurg 13 (1956) $1-42$

39. Brown AK, McGarry JA: Eclampsia with hyperpyrexia: a case treated by total body cooling. Scot Med J 6 (1961) 311-313

40. Busciglio J, Yankner BA: Apoptosis and increased generation of reactive oxygen species in Down's syndrome neurons in vitro. Nature 378 (1995) 776-779

41. Busto R, Dietrich WD, Globus M, Valdés İ. Scheinberg P. Ginsberg MD: Small differences in intraischemic brain temperature critically determine the extent of ischemic neuronal injury. J Cereb Blood Flow Metab 7 (1987) 729-738

42. Busto R, Globus MYT, Dietrich WD, Martinez E, Valdés I, Ginsberg MD: Effect of 
mild hypothermia on ischemic-induced release of neurotransmitters and free fatty acids in rat brain. Stroke 20 (1989) $904-910$

43. Caldwell M, O'Neill M, Earley B, Leonard B: NG-nitro-L-arginine protects against ischaemia-induced increases in nitric oxide and hippocampal neuro-degeneration in the gerbil. Eur J Pharmacol 260 (1994) 191-200

44. Cao X, Phillis JW: The free radical scavenger, alpha-lipoic acid, protects against cerebral ischemia- reperfusion injury in gerbils. Free Radic Res 23 (1995) 365-370

45. Cheng Y, Deshmukh M, D Costa A, Demaro JA, Gidday JM, Shah A, Sun Y, Jacquin MF, Johnson EM, Holtzman DM: Caspase inhibitor affords neuroprotection with delayed administration in a rat model of neonatal hypoxic-ischemic brain injury. J Clin Invest 101 (1998) 1992-1999

46. Choi DW: Calcium-mediated neurotoxicity: relationship to specific channel types and role in ischemic damage. TINS 11 (1988) 465-469

47. Choi DW: The role of glutamate neurotoxicity in hypoxic-ischemic neuronal death. Ann Rev Neurosci 13 (1990) 171-82.

48. Choi DW: Excitotoxic cell-death. J Neurobiol 23 (1992) 1261-1276

49. Chumas PD, Del Bigio MR, Drake JM, Tuor UI: A comparison of the protective effect of dexamethasone to other potential prophylactic agents in a neonatal rat model of cerebral hypoxia/ischemia. J Neurosurg 79 (1993) $414-420$

50. Coimbra C, Wieloch T: Moderate hypothermia mitigates neuronal damage in the rat brain when initiated several hours following transient ischemia. Acta Neuropathol 87 (1994) 325-331

51. Coumans ABC, Middelanis J, Garnier Y, Leib Si, von Duering M, Hasaar THM, Berger R: Intrathecal endotoxin (LPS) aggravates hypoxic-ischemic brain damage in neonatal rats, J Soc Gynecol Investig 9 (2002) 121 A

52. Coyle JT, Enna SJ: Neurochemical aspects of the ontogenesis of GABAergic neurons in the rat brain. Brain Res 111 (1976) 119-133

53. Craig TV, Hunt W, Atkinson R: Hypothermia - its use in severe carbon monoxide poisoning. N Engl J Med 261 (1959) 854-856

54. Dalkara T, Moskowitz MA: The complex role of nitric oxide in the pathophysiology of focal cerebral ischmia. Brain Pathol 4 (1994) 49-57

55. Dambska M, Laure-Kamionowska M, Schmidt-Sidor B: Early and late neuropathological changes in white matter damage. J Child Neurol 4 (1989) 29I-298

56. Dammann O, Leviton A: Maternal intrauterine infection, cytokines, and brain damage in the preterm infant. Pediatr Res 42 (1997) 1-8

57. Dawson DA: Nitric oxide and focal ischemia: multiplicity of actions and diverse outcome. Cerebrovasc Brain Metab Rev 6 (1994) 299-324

58. de Haan HH, Van Reempts JL, Vles JS, de Haan J, Hasaart THM: Effects of asphyxia on the fetal lamb brain. Am J Obstet Gynecol I69 (1993) 1493-1501. 
59. de Haan HH, Gunn AJ, Williams CE, Heymann MA, Gluckman PD: Magnesium sulfate therapy during asphyxia in near-term fetal lambs does not. compromise the fetus but does not reduce cerebral injury. Am J Obstet Gynecol 176 (1997) 18-27.

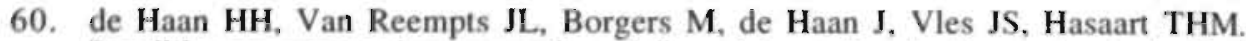
Possible neuroprotective properties of flunarizine infused after asphyxia in fetal lambs are not explained by effects on cerebral blood flow or systemic blood pressure.Pediatr Res 34 (1993) 379-384.

61. de Vries LS, Wigglesworth JS, Regev R, Dubowitz LM: Evolution of periventricular leukomalacia during the neonatal period and infancy: Correlation of imaging and postmortem findings. Early Hum Dev 17 (1988) 205-219

62. Dragunow M, Beilharz E, Sirimanne E, Lawlor P, Williams CE, Bravo R, Gluckman PD: Immediate-early gene protein expression in neurons undergoing delayed death, but not necrosis, following hypoxic-ischemic injury to the young rat brain. Molecular Brain Res 25 (1994) 19-33

63. Drake CG, Barr HWK, Coles JC, Gergely NF: The use of extracorporal circulation and profound hypothermia in the treatment of ruptured intracranial aneurysm. J Neurosurg 2l' (1964) 575-581

64. East SJ, Garthwaite J: NMDA receptor activation in rat hippocampus induces cGMP formation through the L-arginine-nitric oxide pathway. Neurosci Lett 123 (1991) 17. 19

65. Etzioni A: Adhesion molecules - their role in health and disease. Pediatr Res 39 (1996) 191-198

66. Fellman V, Raivio KO: Reperfusion injury as the mechanism of brain damage after perinatal ashyxia. Pediatr Res 41 (1996) 599-606

67. Ferriero DM, Soberano HQ. Simon RP, Sharp FR: Hypoxia-ischemia induces heal shock protein-like (HSP72) immunoreactivity in neonatal rat brain. Dev Brain Res $53(1990) 145-150$

68. Ford LM, Sanberg PR. Norman AB. Fogelson MH: MK-801 prevents hippocanpal neurodegeneration in neonatal hypoxic-ischernic rats. Arch Neurol 46 (1989) 1090 1096

69. Fridovich I: The biology of the oxygen radicals. The superoxide radical is an agent of oxygen toxicity; superoxide dismutases provide an important defense. Science 201 (1978) 875.880

70. Fridovich I: Superoxide radical: an endogenous toxicant. Annu Rev Pharmacol Toxicol 23 (1983) 239-257

71. Friede RL: Developmental Neuropathology. New York, Springer Verlag 1989

72. Funato M, Tamai H, Noma K, Kurita T, Kajimoto Y, Yoshioka Y, Shimada S: Clinical events in association with timing of intraventricular hemorrhage in preterm. infants. J Pediatr 121 (1992) 614-619

73. Gamier Y, Coumans ABC, Jensen A, Berger R, Hasaart THM: Endotoxemia severely affects circulation during normoxia and asphyxia in immature fetal sheep. J Soc Gynecol Investig 8 (2001) 134-142 
74. Garnier $\mathrm{Y}$, Coumans ABC, Vaihinger HM, von Duering M, Supcun S, Berger R, Hasaan THM: Low dose endotoxin (LPS) results in substantial umbilico-placental vasoconstriction and discrete neuropathological changes in preterm sheep. J Soc Gynecol Investig 9 (2002) 72A-73A

75. Garthwaite J: Glutamate, nitric oxide and cell-cell signaling in the nervous system. Trends Neurosci 14 (1991) 60-67

76. Gehrmann J, Bonnekoh P. Miyazawa T, Oschlies U, Duz E, Hosmann KA, Kreutzberg GW: The microglia reaction in the rat hippocampus following global ischemia: immunoelectron microscopy. Acta Neuropathol 84 (1992) 588-595

77. Gilland E, Puka-Sundvall M, Andine P, Bona E, Hagberg H: Hypoxic-ischemic injury in the neonatal rat brain: effects of pre- and post-treatment with the glutamate release inhibitor BW1003C87. Dev Brain Res 83 (1994) 79-84

78. Goldberg RN, Chung D, Goldman SL, Bancalari E: The association of rapid volume expansion and intraventricular hemorrhage in the preterm infant. J Pediatr 96 (1980) $1060-1063$

79. Goplerud JM, Mishra OP, Delivoria-Papadopoulos M: Brain cell membrane dysfunction following acute asphyxia in newborn piglets. Biol Neonate 61 (1992) $33-41$

80. Granger DN: Role of xanthine oxidase and granulocytes in ischemia-reperfusion injury. Am J Physiol 255 (1988) HI269-HI275

81. Green EJ. Dietrich WD, van Dijk F, Busto R, Markgraf CG, McCabe PM, Ginsberg MD, Schneiderman N: Protective effect of brain hypothermia on behavior and histopathology following global cerebral ischemia in rats. Brain Res 580 (1992) 197 204

82. Gunn AJ, Mydlar T, Bennet L, Faull RLM, Gorter S, Cook. C, Johnston. BM, Gluckman PD: The neuroprotective actions of a calcium antagonist, flunarizine, in the infant rat. Pediatr Res 25 (1989) 573-576.

83. Gunn AJ, Williams CE, Mallard EC. Tan WKM, Gluckman PD: Flunarazine, a calcium channel antagonist, is partially prophylactically neuroprotective in. hypoxic/ischemic encephalopathy in the fetal sheep. Pediatr Res 35 (1994) 657-63

84. Gunn AJ, Gunn TR, de Haan HH, Williams CE, Gluckman PD: Dramatic neuronal rescue with prolonged selective head cooling after ischemia in fetal lambs. J Clin Invest 99 (1997) 248-256

85. Gunn AJ, Gluckman PD, Gunn TR: Selective head cooling in newborn infants after perinatal asphyxia: A safety study. Pediatrics 102 (1998) 885-892

86. Gunn AJ, Gunn TR, Gunning MI, Williams CE, Gluckman PD: Neuroprotection with prolonged head cooling started before postischemic seizures in fetal sheep. Pediatrics. 102 (1998) 1098-1106

87. Hadjiconstantinou M, Yates AJ, Neff NH: Hypoxia-induced neurotransmitter deficits in neonatal rats are partially corrected by exogenous GMI ganglioside. J Neurochem 55 (1.990) 864-869 
88. Hagberg H, Gilland E, Diemer NH, Andine P: Hypoxia-ischemia in the neonatal rat brain: histopathology after post treatment with NMDA and non-NMDA receptor antagonists. Biol Neonate 66 (1994) 205-213

89. Hai T, Curran T: Cross-family dimerization of transcription factors Fos/Jun and ATF/CREB alters DNA binding specifity. Proc Natl Acad Sci USA. 88 (1991) 37203724

90. Hajakawa T, Hamada Y, Maihara T, Hattori H, Mikawa H: Phenytoin reduces neonatal hypoxic/ischemic brain damage in rats. Life Sci 54 (1994a) 387-392

91. Hajakawa T, Higuchi $\mathrm{Y}$, Nigami $\mathrm{H}$, Hattori $\mathrm{H}$ : Zonisamide reduces hypoxic/ischemic brain damage in neonatal rats irrespective of its anticonvulsive effect. Eur $J$ Pharmacol 257 (1994) 131-136

92. Hallak M, Hotra JW, Kupsky WJ. Magnesium sulfate protection of fetal rat brain from severe maternal hypoxia. Obstet Gynecol 96 (2000) 124-28.

93. Hall ED. Braughler JM, Yonkers PA, Smith SL, Linseman KL, Means ED, Scherch HM, Von Voigtlander PF, Lahti RA, Jacobsen EJ.: U-78517F: A potent inhibitor of lipid peroxidation with activity in experimental brain injury and ischemia. J Pharmacol Exp Ther 258i (1991) 688-694

94. Halliwell B, Gutteridge JMC, Cross CE: Free radicals, antioxidants, and human disease: where are we now? J Lab Clin Med 199 (1992) 599-620

95. Hamada Y, Hayakawa T, Hattori H, Mikawa H: Inhibitor of nitric oxide synthesis reduces hypoxic/ischemic brain damage in the neonatal rat. Pediatr Res 35 (1994) $10-14$

96. Hamada J, Greenberg JH, Croul S, Dawson TM, Reivich M: Effects of central inhibition of nitric oxide synthase on focal cerebral ischemia in rats. J Cereb Blood Flow Metab 15 (1995) 779-786

97. Hambleton $G$. Wigglesworth JS: Origin of intraventricular haemorrhage in the preterm infant. Arch Dis Child 51 (1976) 651-659

98. Hansen AJ: Effect of anoxia on ion distribution in the brain. Physiol Rev 65 (1985) $101-148$

99. Hasegawa K, Yoshioka H, Sawada T, Nishikawa H: Direct measurement of free radicals in the neonatal mouse brain subjected to hypoxia: an electron spin resonance spectroscopic study. Brain Res 607 (1993) 161-166

100. Hattori H. Morin AM, Schwartz PH, Fujikawa DG, Waterlain CG: Posthypoxic treatment with MK- 801 reduces hypoxic/ischemic damage in the neonatal rat. Neurology 39 (1989) 713-718

101. Heiss WD, Graf R. The ischemic penumbra. Current Opinion in Neurology 7 (1994) $11-19$

102. Higuchi Y, Hattori H. Hattori R, Furusho $\mathrm{K}$ : Increased neurons containing neuronal nitric oxide synthase in the brain of hypoxic-ischemic neonatal rat model. Brain Dev 18 (1996) $369-375$

103. Higuchi Y, Hattori H. Kume T. Tsuji M. Akaike A, Furusho K: Increase in nitric 
oxide in the hypoxic-ischemic neonatal rat brain and suppression by 7-nitroindazole and aminoguanidine. Eur J Pharamacol 342 (1998) 47-49

104. Hoffman DJ, Marro PJ, McGowan JE, Mishra OP, Delivoria-Papadopoulos M. Protective effect of $\mathrm{MgSO}_{4}$ infusion on nmda receptor binding characteristics during cerebral cortical hypoxia in the newborn piglet. Brain Res 644 (1994) 144-149

105. Hossmann KA, Widmann. R, Wiessner C, Dux E, Djuricic B, Röhn G: Protein synthesis after global cerebral ischemia and selective vulnerability. In: Krieglstein J, H Oberpichler-Schwenk (eds.): Pharmacology of Cerebral Ischemia. Wissenschaftliche Verlags-gesellschaft mbH, Stuttgart 1992, 289-299

106. Hossmann KA: Ischemia-mediated neuronal injury, Resuscitation 26 (1993) 225-235

107. Hossmann KA: Mechanisms of ischemic injury: is glutamate involved? In: Krieglstein J. H Oberpichler-Schwenk: Pharmacology of Cerebral Ischemia. Wissenschaftliche Verlagsgesellschaft GmbH, Stuttgart 1994, 239-251

108. Howell DA, Stratford JG, Posnikoff J: Prolonged hypothermia in treatment of massive cerebral haemorrhage. A preliminary report. Can Med Assoc J 75 (1956) 388-394

109. Huang Z, Huang PL, Panahian N, Dalkara T, Fishman MC, Moskowitz MA: Effects of cerebral ischemia in mice deficient in neuronal nitric oxide synthase. Science 265 (1994) 1883-1885

110. Jensen A, Berger R: Fetal circulatory responses to oxygen lack. J Dev Physiol 16 (1991) 181-207

111. Jensen A, Klingmüller V, Künzel W, Sefkow S: Das Hirnblutungs-risiko bei Frühund Reifgeborenen. Geburtsh u Frauenheilk 52 (1992) 6-20

112. Jensen FE, Applegate CD, Holtzman D, Belin TR, Burchfiel JL: Epileptogenic effects of hypoxia on immature rodent brain. Ann Neurol 29 (1991) 629-637

113. Jensen FE, Blume H, Alvarado S, Firkusny I, Geary C: NBQX blocks the acute and late epileptogenic effects of perinatal hypoxia. Epilepsia 36 (1995) 966-972

114. Jensen FE: Perinatal hypoxic-ischemic brain injury: Maturation-dependent relation to epilepsy. MRDD Res Rev 3(1997) 85-95

115. Kleihues P, Hossmann KA, Pegg AE, Kobayashi K, Zimmermann V: Resuscitation of the monkey brain after one hour of complete ischemia III. Indications of metabolic recovery. Brain Res 95 (1975) 61-73

116. Kochhar A, Zivin JA, Lyden PD, Mazzarella V: Glutamate antagonist therapy reduces neurologic deficits produced by focal central nervous system ischemia. Arch Neurol 45 (1988) 148-153

117. Khrestchatisky M. Timsit S, Rivera S, Tremblay E, Ben-Ari Y: Neuronal death and damage repair: roles of protooncogenes and cell cycle-related proteins. In: Krieglstein J (Ed.), Pharmacology of Cerebral Ischemia, medpharm Scientific Publishers, Stuttgart, pp 41-56, 1996

118. Kuluz JW, Prado RJ, Dietrich WD, Schleien CL, Watson BD: The effect of nitric oxide synthase inhibition on infaret volume after reversible focal cerebral ischemia 
in conscious rats. Stroke 24 (1993) 2023-2029

119. Larroche JC: Developmental Pathology of the Neonate. Excerpta Medica, New York 1977

120. Larroche JC: Fetal encephalopathies of circulatory origin. Biol Neonate 50 (1986) $61-74$

121. Le Blanc MH, Vig V, Smith B, Parker CC, Evans OB, Smith EE: MK-80I does not protect against hypoxic/ischemic brain injury in piglets. Stroke 22 (1991) 1270-1275

122. Le Blanc MH, Vig V, Ranhawa T, Smith EE, Parker CC, Brown EG: Use of polyethylene glycol-bound superoxide dismutase, polyetylene glycol-bound catalase, and nimodipine to prevent hypoxic ischemic injury to the brain of newborn pigs. Crit Care Med 21 (1993) 252-259

123. Lesage AS, Peeters L, Leysen JE. Lubeluzole, a novel long-term neuroprotectant, inhibits the glutamate-activated nitric oxide synthase pathway. J Pharmacol Exp Ther 279 (1996) 759-766.

124. Lewis FJ, Taufic M: Closure of atrial septal defects with aid of hypothermia: experimental accomplishments and the report of one successful case. Surgery (1953) $52-59$

125. Li Y, Chopp M, Zhang ZG, Zaloga C: Induction of DNA fragmentation after 10 to 120 minutes of focal cerebral ischemia in rats. Stroke 26 (1995) 1252-1258

126. Lin Y. Phillips JW: Oxypurinol reduces focal ischemia brain injury in the rat. Neurosci Lett (1991) 187-190

127. Little WJ: Course of lectures on the deformities of the human frame. Lancet ! (1844) 350-354

128. Longo LD: Hypoxia-ischaemia and the developing brain: Hypotheses regarding the pathophysiology of fetal-neonatal brain damage. Br J Obstet Gynaecol 104 (1997) $652-662$

129. Lou HC, Lassen NA. Tweed WA. Johnson G, Jones M, Palahniuk RJ: Pressure passive cerebral blood flow and breakdown of the blood-brain barrier in experimental fetal asphyxia. Acta Paediatr Scand 68 (1979) 57-63

130. Lou HC. Tweed WA. Davies JM: Preferential blood flow increase to the brain stem in moderate neonatal hypoxia: Reversal by naloxone. Eur J Pediatr 144 (1985) 225 227

131. Lougheed WM, Sweet WH, White JC, Brewster WR: The use of hypothermia in surgical treatment of cerebral vascular lesions. A preliminary report. J Neurosurg 12 (1955) $240-255$

132. Lynch RE, Fridovich I: Permeation of erythrocyte stroma by superoxide radical. J Biol Chem 253 (1978) 4697-4699

133. Maher J, Hachinski V: Hypothermia as a potential treatment for cerebral ischemia. Cerebrovasc Brain Metab Rev 5 (1993) 277-300

134. Maiese K. Vincent AM. Critical temporal modulation of neuronal programmed cell 
injury. Cell Mol Neurobiol 20 (2000a) 383-400.

135. Maiese K, Vincent AM. Membrane asymmetry and DNA degradation: functionally distinct determinants of neuronal programmed cell death. J Neurosci Res 200059 (2000b) 568-580.

136. Marannes R, De Prins E. Site of action of lubeluzole on voltage-sensitive $\mathrm{Ca}^{2 *)}$ channels in isolated dorsal root ganglion cells of the rat: influence of $\mathrm{pH} . J$ Pharmacol Exp Ther 295 (2000) 531-545.

137. Marks KA, Mallard CE, Roberts I, Williams CE, Gluckman PD, Edwards AD: Nitric oxide synthase inhibition attenuates delayed vasodilation and increases injury after cerebral ischemia in fetal sheep. Pediatr Res 40 (1996) 185-191

138. Marshall TA, Marshall F, Reddy PP: Physiologic changes associated with ligation of the ductus arteriosus in preterm fetuses. I Pediatr 101 (1982) 749-753

139. Martin D, Chinookoswong N, Miller G: The interleukin-1 receptor antagonist (rhILIra) protects against cerebral infarction in a rat model of hypoxia/ischemia. Exp Neurol 130 (1994) 362-367

140. Martz D, Rayos G, Schielke GP, Betz AL: Allopurinol and dimethylthiourea reduce brain infarction following middle cerebral artery occlusion in rats. Stroke 20 (1989) $488-494$

141. Matsuo Y, Onodera H, Shiga Y, Nakamura M, Ninomya M, Kihara T, Kogure K: Correlation between myeoloperoxidase-quantified neutrophil accumulation and ischemic brain injury in the rat. Effects of neutrophil depletion. Stroke 25 (1994) $1469-1475$

142. Maulik D, Zanelli S, Numagami Y, Ohnishi ST, Mishra OP. Delivoria-Papadopoulos M. Oxygen free radical generation during in-utero hypoxia in the fetal guinea pig brain: the effects of maturity and of magnesium sulfate administration. Brain Res 817 (1999) 117-122

143. McCord JM: Oxygen-derived free radicals in postischemic tissue injury. N Engl J Med 312 (1985) 159-163

144. McDonald JW, Silverstein FS, Johnson MW: MK- 801 protects the neonatal brain from hypoxic/ischemic damage. Eur J Pharmacol I40 (1987) 359-36I

145. McDonald JW, Silverstein FS, Cardona D, Hudson C, Chen R, Johnston MV: Systemic administration of MK-80I protects against N-methyl-D-aspartate- and quisqualate-mediated neurotoxicity in perinatal raț. Neuroscience 36 (1990) 589599

146. McManus JP, Buchan AM, Hill IE, Rasquinha I, Preston E: Global ischemia can cause DNA fragmentation indicative of apoptosis in rat brain. Neurosci Lett 164 (1993) 89-92

147. McRae A, Gilland E, Bona E, Hagberg H: Microglia activation after neonatal hypoxia-ischemia. Dev Brain Res 84 (1995): 245-252

148. Mehmet H, Yue X, Squier MV, Lorek A, Cady E, Penrice J, Sarraf C, Wylezinska M, Kirkbridge V. Cooper C, Brown GC, Wyatt JS, Reynolds EOR, Edwards AD: Increased apoptosis in the cingulate sulcus of newborn piglets following transient 
hypoxia-ischemia is related to the degree of high energy phosphate depletion during the insult. Neurosci Lett 181 (1994) 121-125

149. Ment LR, Stewart WB, Ardito TA, Madri JA: Germinal matrix microvascular maturation correlates inversely with the risk period for neonatal intraventricular hemorrhage. Brain Res Dev Brain Res 84 (1995) 142-149

150. Milligran DW: Failure of autoregulation and intraventricular haemorrhage in preterm infants. Lancet 1 (1980) 896-898

151. Minami M, Kurashi Y, Yabuuchi K, Yamazaki A, Satoh M: Induction of interleukinIB mRNA in rat brain after transient forebrain ischemia. J Neurochem 58 (1992) 390-392

152. Mink RB, Dutka AJ, Hallenbeck JM: Allopurinol pretreatment improves evoked response recovery following global cerebral ischemia in dogs. Stroke 22 (1991) 660665

153. Mishra OP, Delivoria-Papadopoulos M: Lipid peroxidation in developing fetal guinea pig brain during normoxia and hypoxia. Dev Brain Res 45. (1989) 129-135

154. Mishra OP, Delivoria-Papadopoulos M. NMDA receptor modification in the fetal guinea pig brain during hypoxia. Neurochemical Res 17 (1992) 121 1-1216

155. Miyashita T, Krajewski S, Krajewski M, Wang H, Lin H, Liebermann D, Hoffmann B, J Reed: Tumor suppressor p53 is a regulator of bcl-2 and bax gene expression in vitro and in vivo. Oncogene 9 (1994) 1799-1805

156. Moody DM, Brown WR, Challa VR, Block SM: Alkaline phophatase histochemical staining in the study of germinal matrix hemorrhage and brain vascular morphology in a very low birth-weight neonate. Pediatr Res 35 (1994) 424-430

157. Morioka T, Kalehua AN, Streit WJ: Progressive expression of immunomolecules on microglial cells in rat dorsal hippocampus following transient forebrain ischemia. Acta Neuropathol 83 (1992) 149-157

158. Munell F, Burke RE, Bandele A. Gubits RM: Localization of c-fos, c-jun, and hsp70 mRNA expression in brain after neonatal hypoxia-ischemia. Dev Brain Res 77 (1994) II1-121

159. Nagufuji T, Sugiyama M. Matsui T. Koide T: A narrow therapeutical window of a nitric oxide synthase inhibitor against transient ischemic brain injury. Eur $\mathrm{J}$ Pharmacol 248 (1993) 325-328

160. Nakamura Y, Okudera T, Fukuda S, Hashimoto T: Germinal matrix hemorrhage of venous origin in preterm neonates. Hum Pathol 21 (1990) 1059-1062

161. Negrin J: Selective local hypothermia in neurosurgery. N Y State J Med 61 (1961) 2951-2965

162. Nelson KB, Grether JK: Can magnesium sulfate reduce the risk of cerebral palsy in very low birthweight infants? Pediatrics 95 (1995) 263-269

163. Nishikawa T, Kirsch JR, Koehler RC, Bredt DS, Snyder SH. Traystman RJ: Effect of nitric oxide synthase inhibition on cerebral blood flow and injury volume during focal ischemia in cats. Stroke 24 (1993) 1717-1724 
164. Norman MG: Perinatal brain damage. Perspect Pediatr Pathol 4 (1978) $41-92$

165. Nowak L. Bergestovski P. Ascher P, Herbelt A, Prochiantz A. Magnesium gates glutamate activated channels in mouse central neurons. Nature 307 (1984) 462-465

166. Nozaki K, Beal MF: Neuroprotection effects of L-kynurenine on hypoxic-ischemic and NMDA lesions in neonatal rats. J Cereb Blood Flow Metab 12 (1992) 400-407

167. Nozaki K, Finkelstein SP. Beal MF: Basic fibroblast growth factor protect against hypoxia/ischemia and neonatal rats. J Cereb Blood Flow Metab 13 (1993) 221-228

168. Obrenovitch TP, Urenjak J, Zilkha E: Excitotoxicity in cerebral ischemia: Alternative hypothesis to high extracellular glutamate. In: Krieglstein J: Pharmacology of Cerebral Ischemia, pp 9-23. Medpharm Scientific Publishers, Stuttgart 1996

169. Ohrt B, Riegel R, Wolke D: Langzeitprognose sehr kleiner Früheborener. Arch Gynecol Obstet 257 (1996) 480-492

170. Oillet J, Koziel V, Vert P. Daval J-L: Influence of post-hypoxia reoxygenation conditions on energy metabolism and superoxide production in cultured neurons from the rat forebrain. Pediatr Res 39 (1996) 598-603

171. Okada Y, Copeland BR, Mori E, Tung MM, Thomas WS, del Zoppo GJ: P-selectin and intercellular adhesion molecule-1 expression after focal brain ischemia and reperfusion. Stroke 25 ( 1994) 202-21 I

172. Olney JW: Brain lesions, obesity, and other disturbances in mice treated with monosodium glutamate. Science 164 (1969) 719-721

173. Olney JW, Sharpe LG, Feigin RD: Glutamate-induced brain damage in infant primates. J Neuropathol Exp Neurol 31 ( 1969) 464-488

174. Palmer C, Vannucci RC, Towfighi J: Reduction of perinatal hypoxic-ischemic brain damage with allopurinol. Pediatr Res 27 (1990) 332-336

175. Palmer C, Towfighi J, Roberts RL, Heitjan DF: Allopurinol administered after inducing hypoxia/ischemia reduces brain injury in 7-days-old rats. Pediatr Res 33(1993) 405-411

176. Palmer C, Roberts RL, Bero C: Deferoxamine posttreatment reduces ischemic brain injury in neonatal rats. Stroke 25 (1994) I039- 1045

177. Palmer C: Hypoxic-ischemic encephalopathy. Therapeutic approaches against microvascular injury, and the role of neutrophils, PAF, and free radicals. Clin Perinatol 22 (1995) $481-517$

178. Palmer C, Roberts RL, Young PI: Neutropenia before but not after hypoxia/ischemia reduces brain injury in neonatal rats. J Cereb Blood Flow Metab 15 (1995) 291

179. Paneth N, Rudelli R, Monte W, Rodriguez E, Pinto J, Kairam R, Kazam E: White matter necrosis in very low birth weight infants: Neuropathologic and ultrasonographic findings in infants surviving six days or longer. J Pediatr 116 ( 1990$)$ 975-984 
180. Park CK, Nehls DG, Teasdale GM und McCulloch J: The glutamate antagonist MK801 reduces focal ischemic brain damage in the rat. Ann Neurol 24 (1988) 543-551

181. Parkhouse J: General anesthesia as an aid to therapeutic hypothermia. Br Med J 2 (1957) 751

182. Patt A, Horesh IR, Berger EM, Harken AH, Repine JE: Iron depletion or chelation reduces ischemia/reperfusion-induced edema in gerbil brains. J Pediatr Surg 25 (1990) 224-228

183. Patten RM, Mack LA, Nyberg DA, Filly RA: Twin embolization syndrome: Prenatal sonographic detection and significance. Radiology 173 (1989) 685-689

184. Penrice J, Lorek A, Cady EB, Amess PN, Wylenezinska M, Cooper CE, D'Souza P. Brown GC, Kirkbridge V, Edwards AD, Wyat, Reynolds EOR: Proton magnetic resonance spectroscopy of the brain during acute hypoxia-ischemia and delayed cerebral energy failure in the newborn piglet. Pediatr Res 41 (1997) 795-802

185. Perides G, Jensen FE, Edgecomb P, Rueger DC, Charnes ME: Neuroprotective effect of human osteogenic protein-1 in a rat model of cerebral hypoxia ischemia. Neurosci Lett 187 (1995) 21-24

186. Pryds O, Greise G, Lou H, Friis-Hansen B: Vasoparalysis associated with brain damage in asphyxiated term infants. J Pediatr 117 (1990) 119-125

187. Ratan RR, Murphy TH, Barban JM: Oxidative stress induces apoptosis in embryonic corticol neurons. J Neurochem 62 ( 1994) 376-379

I88. Reed J: Bcl-2 and the regulation of programmed cell death. J Cell Biol I24 (1994) 12

189. Ringel M, Bryan RM. Vannucci RC. Regional cerebral blood flow during hypoxiaischemia in the immature rat: comparison of iodoantipyrine and iodoamphetamine as radioactive tracers. Dev Brain Res 59 (1991) 231-235

190. Romson IL, Hook BG, Kunkel SL, Abrams GD. Schork MA, Lucchesi BR: Reduction of the extent of ischemic myocardial injury by neutrophil depletion in the dog. Circulation 67(1983) 1016-1023

191. Rorke LB: Anatomical features of the developing brain implicated in pathogenesis of hypoxic-ischemic injury, Brain Pathol 2 (1992) 211-221

192. Rosenbaum DM, Michaeison M. Batter DK, Doshi P, Kessler JA: Evidence for hypoxia-induced, programmed cell death of cultured neurons. Ann Neurol 36 (1994) $864-870$

193. Rosenberg AA, Murdaugh E, and White CW: The role of oxygen free radicals in postasphyxia cerebral hypoperfusion in newborn lambs. Pediatr Res 26 (1989) 215219

194. Rothman SM: Synaptic release of excitatory amino acid neurotransmitter mediates anoxic neuronal death. J Neurosci (1984) 1884-1891

195. Rothwell NJ, Hopkins SJ: Cytokines and the nervous system. II. Actions and mechanisms of action. Trends Neurol Sci 18 (1995) 130-136. 
196. Sameshima H, Ota A, Ikenoue T. Pretreatment with magnesium sulfate protects against hypoxic-ischemic brain injury but postasphyxial treatment worsens brain damage in seven-day-old rats. Am J Obstet Gynecol 180 (1999) 725-730

197. Scheller D, De Ryck M, Kolb J, Szathmary S, Van Reempts J, Clincke B, Tegtmeier F. Lubeluzole blocks increases in extracellular glutamate and taurine in the periinfarct zone in rats. Eur $\mathrm{J}$ Pharmacol 338 (1997) 243-251.

198. Scheller JM, Nelson KB: Twinning and neurologic morbidity. Am J Dis Child 146 (1992) 1110-1113

199. Schendel DE, Berg CJ, Yeargin-Allsopp M, Boyle CA, Decoufle P: Prenatal magnesium sulfate exposure and risk for cerebral palsy or mental retardation among very low-birth-weight children aged 3 to 5 years. JAMA 276 (1996) 1805-1810

200. Schoepfer R. Monyer H, Sommer B, Wisden W, Sprengel R, Kuner T, Lomeli H, Herb A, Kohler M, Burnashev N, Gunther W, Ruppersberg P, Seeburg P: Molecular biology of glutamate receptors. Prog Neurobiol 42 (1994) 353-357

201. Sedzimir CB: Therapeutic hypothermia in cases of head injury. J Neurosurg 16 (1959) $407-414$

202. Siesjö BK, Bengtsson F: Cal'cium fluxes, calcium antagonists, and calcium-related pathology in brain ischemia, hypoglycemia, and spreading depression: a unifying hypothesis. J Cereb Blood Flow Metab 9 (1989) 127-140

203. Siesjö BK, Katsura K, Pahlmark K, Smith ML: The multiple causes of ischemic brain damage: a speculative synthesis. In: Krieglstein J, Oberpichler-Schwenk H: Pharmacology of Cerebral Ischemia, pp 5II-525. Wissenschaftliche Verlagsgesellschaft GmbH, Stuttgart. (1992)

204. Silverstein FS, Buchanan K. Hudson C, Johnston MV: Flunarizine limits hypoxia/ischemia induced morphologic injury in immature rat brain. Stroke 17 (1986) 477-482

205. Spanggord H, Sheldon RA, Ferriero DM: Cysteamine eliminates nitric oxide synthase activity but is not protective to the hypoxic-ischemic neonatal brain. Neurosci Lett 213 (1996) $41-44$

206. Szymonowicz W, Walker AM, Yu VY, Stewart ML, Cannata J, Cussen L. Regional cerebral blood flow after hemmorrhagic hypotension in the preterm near-term, and newborn lamb. Pediar Res 28 (1990) 361-366

207. Takashima S, Armstrong DL, Becker LE: Subcortical leukomalacia. Relationship to development of the cerebral sulcus and its vascular supply. Arch Neurol 35 (1978) $470-472$

208. Tan WKM, Williams CE, Gunn AJ, Mallard CE, Gluckman PD: Suppression of postischemic epileptiform activity with MK-801 improves neural outcome in fetal sheep. Ann Neurol 32 (1992) 677-682

209. Tan WKM, Williams CE, Gunn AJ, Mallard CE, Gluckman PD: Pretreatment with monosialoganglioside GMI protects the brain of fetal sheep against hypoxic/ischemic injury without causing systemic compromice. Pediatr Res 34 (1993) 18-22 
210. Thordstein M, Bagenholm R, Thiringer K, Kjellmer I. Scavengers of free oxygen radicals in combination with magnesium ameliorate perinatal hypoxic-ischemic brain damage in the rat. Pediatr Res 34 (1993) 23-26

211. Timsit S, Rivera S, Louis NCA, Tremblay E, Guischard F, Ouaghi P, Ben-Ari Y, Khrestchatisky M: Cyclin DI is upregulated in regions of neuronal death during ischemia, epilepsy and in a developmental model of neuronal death. Soc Neurosci Abstr 22 (1996) 1480

212. Traystman RJ, Kirsch JR, Koehler RC: Oxygen radical' mechanisms of brain injury following ischemia and reperfusion. J Appl Physiol 71 (1991) 1185-1195

213. Trifiletti RR: Neuroprotective effects of NG-Nitro-L-arginine in focal stroke in the 7day old rat. Eur J Pharmacol 218 (1992) 197-8

214. Tuor UI, del Bigio MR: Protection against hypoxic/ischemic damage with corticosterone and dexamethasone: inhibition by glucocorticoid antagonist. I Cereb Blood Flow 15 (suppl 1) (1995) 279

215. Tuor UI, Chumas PD, Del Bigio MR: Prevention of hypoxic/ischemic damage with dexamethasone is dependent on age and not influenced by fasting. Exp Neorol 132 (I995) 116-122

216. Tuor UI, del Bigio MR, Chumas PD: Brain damage due to cerebral hypoxia/ischemia in the neonate: pathology and pharmacological modification. Cerebrovasc Brain Metab Rev 8 (1996) 159-193.

217. Uematsu D, Greenberg JH, Araki N, Reivich M: Mechanism underlying protective effects of MK-801 against NMDA-induced neuronal injury in vivo. J Cereb Blood. Flow Metab 11 (1991) 779-785

218. Vannucci RC, Lyons DT, Vasta F: Regional cerebral blood flow during bypoxiaischemia in immature rats. Stroke 19 (1998) 245-250

219. Vannucci RC. Periman JM: Interventions for perinatal hypoxic-ischemic encephalopathy. Pediatrics 100 (1997) 1004-1014

220. Van Reempts J, Borgers M, Van Dael L, van Eyndhoven J, Van de Ven M: Protection with flunarizine against hypoxic-ischemic damage of the rat cerebral cortex. A quantitative morphologic assessment. Arch Int Pharmacodyn Ther $232,(198,3) 76-88$

221. Vedder NB. Winn RK, Rice CL, Chi EY. Arfors KE, Harlan JM: A monoclonal antibody to adherence promoting leukocyte glycoprotein, CD 18, reduces organ injury and improves survival from hemorrhagic shock and resuscitation in rabbits. J Clin Invest 81 ( 1988 ) 939-944.

222. Volpe JJ: Neurology of the Newborn. WB Saunders Company, Philadelphia 1995

223. Volpe $\mathbf{3}$ : Brain injury in the premature infant - from pathogenesis to prevention. Brain Dev 19 (1997) $519-534$

224. Volpe JJ: Perinatal brain injury: from pathogenesis to neuroprotection. MRDD Research Reviews 7 (2001) 56-64

225. Wagner JG, Roth RA: Neutrophil migration during endotoxemia. J Leukoc Biol 66 
(1999) 10-24

226. Wasterlain CG, Adams LM, Schwartz PH, Hattori H, Sofia RD, Wichman JK: Posthypoxic treatment with felbamate is newroprotective in a rat model of hypoxia/ischemia. Neurology 43(1993) 2303-2310

227. Welsh FA, Sims RE, Harris VA: Mild hypothermia prevents ischemic injury in gerbil hippocampus. J Cereb Blood Flow Metab 10 (1990) 557-563

228. Westin B, Miller JA, Nyberg R, Wendenberg E: Neonatal asphyxia pallida treated with hypothermia alone or with hypothermia and transfusion of oxygenated blood. Surgery 45 (1959) 868-879

229. Widmann R, Miyazawa T, Hossmann KA: Protective effect of hypothermia on hippocampal injury after $30 \mathrm{~min}$ of forebrain ischemia in rats is mediated by postischemic recovery of protein synthesis. J Neurochem 61 (1993) 200-209

230. Wiessner C, Brinck I, Lorenz P, Neumann-Haefelin T, Vogel P, Yamashita K: Cyclin DI messenger RNA is induced in microglia rather than neurons following transient forebrain ischemia. Neurosci 72 (1996) 947-958

231. Williams CE, Gunn A, Gluckman PD: Time course of intracellular edema and epileptiform activity following prenatal cerebral ischemia in sheep. Stroke 22 (1991) 516-521

232. Williams CE, Gunn AJ, Mallard C, Gluckman PD: Outcome after ischemia in the developing sheep brain: An electroencephalographic and histological study. Ann Neurol 31 (1992) 14-21

233. Wu YW, Colford JM Jr: Chorioamnionitis as a risk factor for cerebral palsy: A metaanalysis. JAMA $284(2000)$ 1417-1424

234. Xian CJ, Zhou XF: Roles of transforming growth factor-alpha and related molecules in the nervous system. Mol Neurobiol 20 (1999)157-183

235. Xie Y, Seo K, Hossmann KA: Effect of barbiturate treatment on post-ischemic protein biosynthesis in gerbil brain. J Neurol Sci 92 (1989) 317-328

236. Yoon BH, Romero R, Park JS, Kim CJ, Kim SH. Choi JH, Han TR: Fetal exposure to an intra-amniotic inflammation and the development of cerebral palsy at the age of three years: Am. J Obstet Gynecol 182 (2000) 675-81

237. Zhang F, Xu S, Iadecola C: Time dependence of effect of nitric oxide synthase inhibition on cerebral ischemia injury. J Cereb. Blood Flow Metab 15 (1994) 595-60I 
Chapter 2 


\section{Chapter 3}

\section{MATERIAL AND METHODS}

3.1 Sheep experiments (Chapters 4 to 7 )

3.1.1 Animal preparation

3.1.2 Experimental protocols (Chapters 4 and 6)

3.1.3 Experimental protocols (Chapters 5 and 7)

3.1.4 Measurements

3.1.5 Calculations

3.1.6 Statistics

3.2 Hippocampal tissue slice model (Chapters 8 and 9)

3.2.1 Animal preparation

3.2.2 Experimental protocols

3.2.3 Measurements

3.2.4 Statistics

3.3 References 


\subsection{SHEEP EXPERIMENTS (Chapters 4 to 7)}

\subsubsection{Animal preparation}

Surgery was performed in 46 sheep of known mating dates between 121 and 134 days of gestation ('asphyxia-model' $132 \pm 1$ days; 'ischemia-model' $125 \pm 1$ days; term is at 147 days). All ewes were anesthetized by subarachnoid injection of $8 \mathrm{~mL}$ of $0.75 \%$ (w/v) bupivacaine at the lower spine, and were operated under sterile conditions. Polyvinyl catheters were placed into a maternal iliac artery and vein through tibial vessels. The ewe's abdominal wall was opened in the midline and a snare was placed around the descending aorta below the renal artery, which was then used to arrest uterine and ovarian blood flow during the experiment ('asphyxia-model'; Chapters 4 and 6). Care was taken not to include any nerves. The uterus was incised in an area free of cotyledons. Fetal catheters were inserted after local anesthesia (prilocaine HCL $1.0 \%$ ) via the pedal vein of each hindlimb into the inferior vena cava and into the fetal ascending aorta via both brachial arteries. Polyvinyl catheters used had an outer diameter of $1.5 \mathrm{~mm}$ and an inner diameter of $0.75 \mathrm{~mm}$.

In the ischemia-model '(Chapters 5 and 7 ) the second uterine incision was performed over the fetal snout. Head and neck of the fetus were exteriorized. To prevent the fetus from breathing, its head was covered by a water-filled $\left(39^{\circ} \mathrm{C}\right)$ rubber glove. Furthermore, both fetal common carotid arteries were prepared under local anaesthesia. Cerebral ischemia was induced by occluding the carotid arteries bilaterally below the thyroid and above the lingual artery for $30 \mathrm{~min}$. Thus, blood flow to the cerebrum via anastomoses between the carotid and vertebral arteries was arrested. After global cerebral ischemia, a catheter was inserted into the amniotic cavity, and the second intrauterine incision was closed in two layers. Lost amniotic fiuid was replaced by warm $\left(39^{\circ} \mathrm{C}\right)$, saline. All catheters were filled with heparin $(1.000 \mathrm{IU} / \mathrm{mL})$, plugged, and passed s.c. to the ewe's flank, where they were exteriorized and protected by a pouch sewn to the skin. On the day of surgery and each day thereafter, the ewe received 2 million units of penicillin $G$ (Grünenthal, Germany) and 80 mg of gentamycin sulfate (Merck, Germany), half i.v. and half into the amniotic cavity. The fetuses were allowed to recover for 2 days.

\subsubsection{Experimental protocols (Chapters 4 and 6)}

After control measurements of fetal blood gases and acid-base balance as well as physiological variables fetuses were treated either with flunarizine (Chapter 4) or lubeluzole (Chapter 6) intravenously, while fetuses of the control group received solvent. The drugs were donated by Janssen Pharmaceutica, Beerse, Belgium. Detailed information 
on administration, pharmacology, and effects of these drugs are described in the chapters mentioned above.

Each experiment started with a baseline period of at least I hour. Sixty minutes after drug administration (at $0 \mathrm{~min}$ ) uterine blood flow was arrested by a single occlusion of the descending aorta for $2 \mathrm{~min}$ to induce acute fetal asphyxia. To determine drug related effects of flunarizine or lubeluzole on the time course of circulatory centralization before, during and after acute asphyxia, blood flow to fetal organs and the distribution of combined ventricular output were measured by injecting six batches of differently labeled isotope microspheres ( ${ }^{141} \mathrm{Ce},{ }^{114} \mathrm{In},{ }^{113} \mathrm{Sn},{ }^{101} \mathrm{Ru},{ }^{95} \mathrm{Nb}$ and ${ }^{46} \mathrm{Sc}, 16 \mu \mathrm{m}$ diam., New England Nuclear) into the inferior vena cava (Heymann et al. 1977; Rudolph and Heymann 1967). Depending on the activity, 0.7 to 2.8 million microspheres per batch were applied. Microspheres were injected at $75 \mathrm{~s}$ before asphyxia (control measurement), at $1(+1$ ) and 2 $\left(+2^{\prime}\right)$ min during arrest of uterine blood flow, and at I $\left.(+3)^{\circ}\right), 2\left(+4^{\prime}\right)$, and $28\left(+30^{\circ}\right)$ min after release of the snare (recovery period). Reference blood samples were withdrawn from both a carotid and a femoral artery at a rate of $2.5 \mathrm{~mL} / \mathrm{min}$. Sampling was continuous for $270 \mathrm{~s}$ during control, occlusion and the immediate recovery period $\left(-75^{\prime \prime},+11^{\prime},+2{ }^{\prime},+3\right.$, +4 ). Separate samples were taken for 75 s during the 28 -min recovery measurement. The volume of blood withdrawn was about $25 \mathrm{~mL}$ and was simultaneously replaced by maternal blood maintained at $39^{\circ} \mathrm{C}$ in a waterbath.

When using the microspheres method to measure blood flow at $\mathbf{1}-2 \mathrm{~min}$ iniervals the sampling time for reference blood must be adequate and the number of microspheres still circulating 30 to $40 \mathrm{~s}$ after each injection must be negligible. As shown previously these conditions are fulfilled in the present experimental model (Jensen et al. 1987).

\subsubsection{Experimental Protocols (Chapters 5 and 7)}

About $30 \mathrm{~min}$ before preparation of the carotid arteries fetuses received either flunarizine or lubeluzole intravenously, while an equal volume of the solvent was administered to the remaining fetuses. The drugs were donated by Janssen Pharmaceutica, Beerse, Belgium. The dosage applied was within the therapeutic range (Todd and Benfield 1989). The experiments were done in a randomized fashion. The operators were not blind to the nature of injection. Sixty min after drug administration global cerebral ischemia was started. To determine the time course of changes in fetal cerebral blood flow before $(-15 \mathrm{~min})$, during $(+3 \mathrm{~min}$ and $+27 \mathrm{~min})$, and after $(+10 \mathrm{~min},+3 \mathrm{~h},+72 \mathrm{~h}) 30 \mathrm{~min}$ of global cerebral ischemia, six batches of microspheres labelled with different isotopes $\left({ }^{141} \mathrm{Ce},{ }^{114} \mathrm{In},{ }^{113} \mathrm{Sn}\right.$, 
${ }^{103} \mathrm{Ru},{ }^{95} \mathrm{Nb}$ and ${ }^{46} \mathrm{Sc}, 16 \mu \mathrm{m}$ diam., New England Nuclear) were injected into the inferior vena cava, while reference samples from the brachial artery were withdrawn at a rate of 2.5 mL/min for 90, s. (Rudolph and Heymann 1967; Jensen et al. 1987; Berger et al. 1996, 1998). The microspheres, suspended in $10 \%$ dextran containing $0.01 \%$ Tween 80 , were sonicated and checked for size, shape and aggregation. Depending on the specific activity, 1.2-1.8 million microspheres per batch were injected. The number of injected microspheres was large enough to ensure both an adequate number of microspheres per sample and valid blood flow measurements during cerebral ischemia (Buckberg et al. 1971; Jensen et al. 1987). Specific calculations revealed that about 400 microspheres were trapped in low flow cerebral areas during ischemia. Thus, for theoretical considerations the blood flow estimates in these areas are within $5 \%$ of the true values (Buckberg et al. 1971). During and shortly after injection of the microspheres no significant changes in fetal heart rate or arterial blood pressure were found. The volume of blood withdrawn was about $22.5 \mathrm{~mL}$ and was simultaneously replaced by maternal blood maintained at $39^{\circ} \mathrm{C}$ in a water bath.

During and shortly after global cerebral ischemia fetal heart rate, ascending aortic and intrauterine pressure were contionously recorded. After having injected the fourth batch of microspheres (at $+40 \mathrm{~min}$ ) all catheters were closed and secured as described above, the: abdominal wall was closed and the ewe was brought back to the metabolic cage, where the fifth injection (at +3 h) was performed. For technical reasons there were no pressure measurements at this point in time. Before each injection, biood samples were obtained from the brachial artery to measure blood gases, oxygen saturation of hemoglobin, and acid-base balance. At the end of the experiment ( $a t+72 h$ ) the ewe was given a lethal dose of sodium pentobarbitone and saturated potassium chloride intravenously, while the fetus: was perfused with $300 \mathrm{~mL}$ of formalin $(15 \%$, wt/vol, saline).

\subsubsection{Measurements}

Fetal heart rate and arterial blood pressure, amniotic fluid pressure, and maternal arterial blood pressure were recorded on a polygraph (Hellige, Germany) during the experiment. Complete occlusion of the ewe's descending aorta by the snare throughout the 2-min study period was confirmed by the fall in pressure distal to the obstruction (Chapters 4 and 6 ). Before blood flow was measured a blood sample was taken from the descending aorta and analysed for blood gases, acid-base balance (278 Blood Gas System. Ciba Corning. Frankfurt, Germany), hemoglobin concentration, oxygen saturation (OSM 2 Hemoximeter. Radiometer, Copenhagen, Denmark), glucose, lactate, catecholamine and flunarizine concentrations. Plasma concentrations of both catecholamines and flunarizine and brain 
tissue concentrations of flunarizine were determined by reversed phase ion-pair High Performance Liquid Chromatography with electrochemical detection (HPLC-ECD), with a detection limit of $5 \mathrm{pg}$, an intra-assay variance below $5 \%$, and an inter-assay variance below $10 \%$. A detailed description of the HPLC.ECD catecholamine assay is given elsewhere (Jelinek and Jensen 1991; Tegtmeier et al. 1987).

At the end of the experiment a lethal dose of sodium pentobarbitone was given to the ewe and the fetuses were perfused with $300 \mathrm{~mL}$ of formalin $(15 \%$, w/v, saline). Fetal organs and cotyledons were weighed and placed in vials, which were filled to the same height to reduce variations in geometry. The intestines were separated from the mesentery, opened, and cleared of contents. Paired organs (lungs, kidneys, and adrenals) were counted separately, as were the right and left sides of the cerebrum and of the brainstem regions. No significant preferential streaming of microspheres was found. Specimens of skin and muscle were taken from the hips and shoulders of each side. There were no differences in blood flow between the intact side and the side on which the femoral or brachial arteries were catheterized. Upper and lower carcass were carbonized and the aliquots filled into vials.

The applied solid-state semi-conductor germanium (Ge) gamma counter had a high energy resolution of about $3 \mathrm{keV}$ and was connected to a multichannel (2048) pulse height analyzer (ND 62, Nuclear Data Inc., Illinois, USA). The results were normalized with respect to time and sample weight.

\subsubsection{Calculations}

\section{'Asphyxia-model'}

Fetal combined ventricular output and blood flow to the various organs were calculated from counts of the injected nuclide recovered in fetal organs or placenta, from counts in the appropriate reference samples, and from the withdrawal rate of the reference sample (Heymann et al. 1977: Rudolph and Heymann 1967). Portal venous blood flow was calculated by summing the actual blood flow to all gastro-intestinal organs, including stomach, intestines, mesentery, pancreas, and spleen. The percentage of combined ventricular output distributed to a given organ was calculated from the absolute blood flow to that organ and the combined ventricular output. The vascular resistance was calculated by dividing arterial blood pressure (corrected for amniotic fluid pressure) by blood flow and was expressed in $\mathrm{mmHg} / \mathrm{mL} / \mathrm{min} / 100 \mathrm{~g}$ of tissue. Blood flow inferior to I $\mathrm{mL} / \mathrm{min} / 100 \mathrm{~g}$ was treated as 1 . Umbilical vascular resistance $(\mathrm{mmHg} / \mathrm{mL} / \mathrm{min} / \mathrm{kg}$ fetal 
weight) was calculated by dividing the perfusion pressure of the umbilical circulation (arterial blood pressure minus the estimated umbilical venous blood pressure before (11 $\mathrm{mmHg}$ ) and during (17 $\mathrm{mmHg}$ ) reduction in uterine blood flow (Jensen et al. 1991)) by umbilical blood flow.

\section{Tschemia-model'}

Fetal cerebral blood flow and the extent of neuronal cell damage were assessed in identical brain specimens. To determine fetal cerebral blood flow using the microsphere method, the fetal brain was removed and fixed in formalin for at least seven days. Afterwards the cerebrum was separated from the basal ganglia and divided in four frontal sections (rostral, pericentral, postcentral, occipital) with a thickness of about $1.5 \mathrm{~cm}$ (Fig. 7). The right and left parts of these four sections were further subdivided into four equally sized segments (sagittal 1 and 2, lateral 1 and 2) each weighing $1-2 \mathrm{~g}$. In addition to these 32 cerebral specimens, the caudate nucleus, thalamus, hippocampus, tegmentum-colliculi-pons, cerebeilum, and medulla oblongata were separated. These brain structures were placed into vials, which were filled to the same height to reduce variations in geometry during gamma counting. The results were normalized with respect to time and sample weight.

After cerebral blood flow analysis the specimens of the fetal brain were removed from the counting vials and embedded in paraffin. Coronal subserial sections of $10 \mu \mathrm{m}$ were obtained and then stained with cresyl violet/fuchsin. Every 40th section was mounted to evaluate the extent of neuronal cell damage. Neuronal cell damage was assessed at a magnification of 250x. The histological score of each cerebral specimen was calculated by averaging the scores of all visual fields analysed from 3 sections of that specimen. The number of scored visual fields per specimen ranged between 400 and 500 each. The scores from corresponding specimens from the right and left hemisphere were averaged. Neurons with ischemic cell damage were identified according to the criteria of Brown and Brierley (1971). Neuronal cell damage in each microscopical visual field was quantified as follows: 0-5 \% damage (score 1), 5-50 \% damage (score 2), 50-95\% damage (score 3), 95-99\% damage (score 4), $100 \%$ damage (score 5 ).

\subsubsection{Statistics}

Values are given as means \pm standard deviation. The data were analyzed for intragroup and intergrouo differences by two-way multivariate analysis of variance (MANOVA) fo repeated measures. The Games-Howell was used as a post hoc testing procedure. 
Statistical analysis was performed by the Super Anova Statistical Package (Abacus Inc., Ca., USA).

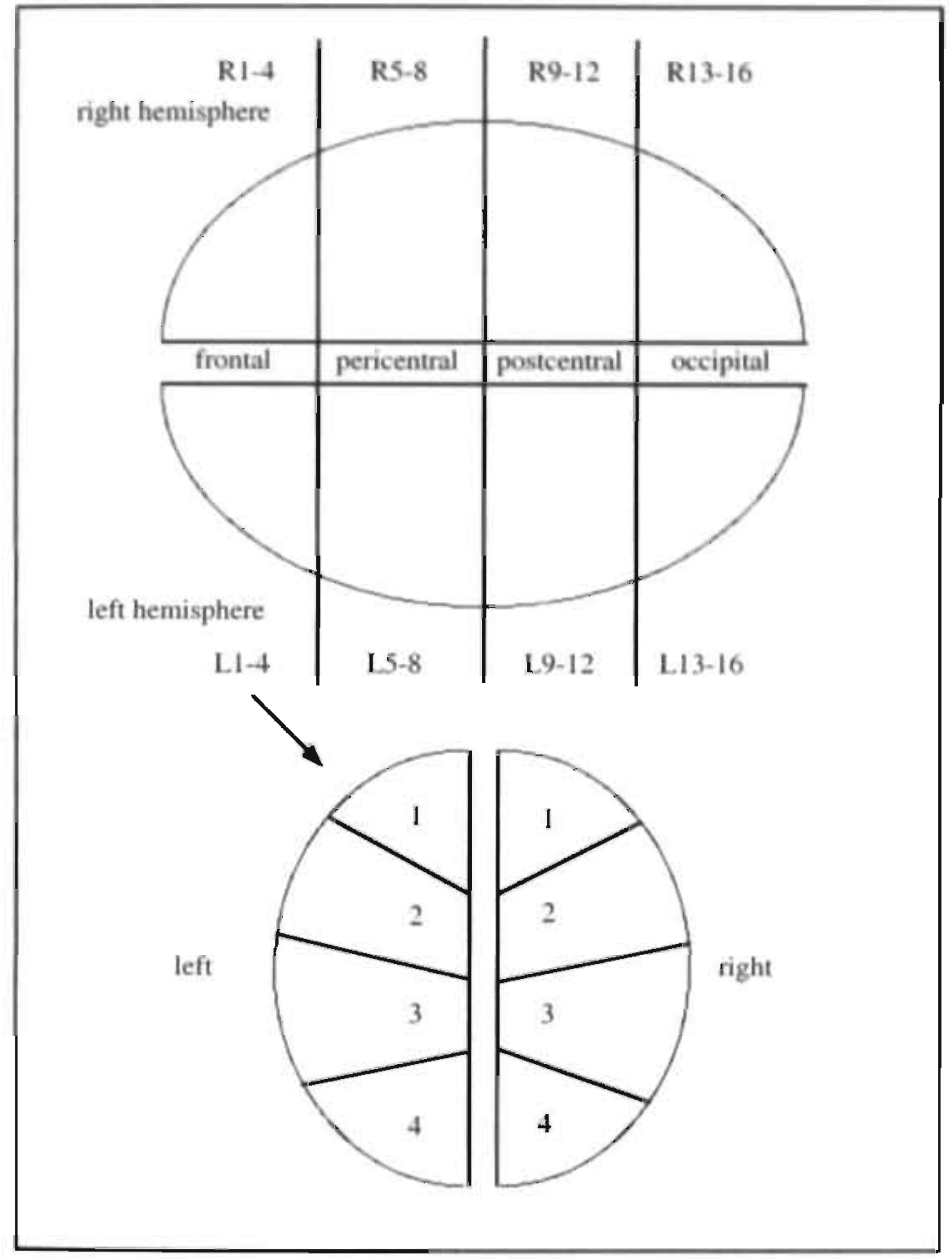

Fig. 7. Schematic illustration of the subdivided cerebrum. 


\subsection{HIPPOCAMPAL TISSUE SLICE MODEL (Chapters 8 and 9) \\ 3.2.1 Animal preparation}

Experiments were performed on mature guinea pig fetuses (E 60). In this species term i at 68 days. For the present study we preferred tissue slices from the hippocampal area, sice this region is known to be very sensitive to hypoxic-ischemic insults in comparison vith other parts of the brain (Hossmann et al. 1992; Penny et al. 1974).

Guinea pig dams were anesthetized with halothane and 64 fetuses were delivered by cesarean section. Until further preparation the fetal heads were kept in ice-water. The sill was then cut along the midline with scissors and removed with forceps. After removal of the skull the brainstem was divided below the cerebellum. The hemispheres were lifted with a spatula and the cranial nerves and the blood vessels were cut to allow the brain to fall gently into a beaker containing ice-cold artificial cerebrospinal fluid ( $\mathrm{aCSF})\left(0^{\prime} \mathrm{C}\right)$. This temperature was strictly maintained throughout the slice preparation period, snce preliminary experiments have shown that preservation of cellular metabolism is impreved ander shese sanditions. Standard aCSF (Diuricic et al. 1994) contained (in mM): $\mathrm{NiCl}$, 111: $\mathrm{NaHCO}_{3}, 26 ; \mathrm{KCl}_{1}, 3 ; \mathrm{KH}_{2} \mathrm{PO}_{4}, 1.4 ; \mathrm{CaCl}_{2}, 1.2 ; \mathrm{MgSO}_{4}, 1.3 ;$ glucose, 10 (standard) or 2 (low glucose; in low glucose aCSF $\mathrm{NaCl}$ was adjusted to $115 \mathrm{mM}$ ) : and $\mathrm{N}$-[2hydroxyethyl]piperazine-N'-[2-ethanesulfonic acid] (HEPES), 5. The aCSF was supplemented with amino acids $(\mu \mathrm{M})$ (Djuricic et al. 1994): alanine, 34; arginine, 22; aspartate, 0.13 ; citrulline, 5.7 ; cystine, 0.12 ; histidine, 13: lysine, 27.7 ; methionine, 3.4 : ornithine, 3.8: phenylalanine, 9.1 ; serine, 28.5; taurine, 8; threonine, 32; tryptophan, 1.5; tyrosine, 8.3 ; valine, 12.8 . To prevent bacterial contamination $10 \mathrm{mg} / \mathrm{L}$ each of streptomycin and erythromycin were added to the aCSF. The aCSF was equilibrated with a gas mixiure of $\mathrm{O}_{2} / \mathrm{CO}_{2}(95 \% / 5 \%)$ for at least $60 \mathrm{~min}$ prior to the experiments. The $\mathrm{pH}$ of the aCSF was adjusted to 7.4 with I $\mathrm{M} \mathrm{NaOH}$ or I $\mathrm{M} \mathrm{HCl}$. For further preparation the fetal brain was transferred from the beaker onto a cooling plate $\left(0^{\circ} \mathrm{C}\right)$ covered with filter paper. The filter paper was moistened with aCSF. The brain was divided into its two halves and the hemispheres were placed with the lateral side down. The brain stem was lifted with a spatula, while the occipital cortex was gently pushed downwards with another spatula until the whole medial and inferior side of the hippocampal formation could be seen. Both ends of the structure were then freed and the hippocampus was rolled upwards and backwards towards the occipital pole by inserting spatulas on both sides under its superior surface. The hippocampal formation now lay with the dentate area down and the alveus up. The hippocampi were then transferred again to chilled standard aCSF until they were cut into slices of 500 ( $\mu \mathrm{m}$ thickness on a tissue slicer (Rademacher. Cologne, Germany). Before use the tissue slicer had been pre-cooled in a refrigerator. The slices were transferred from 
the chopper onto a nylon mesh with a painting brush. The nylon mesh was stretched across a plastic ring and immersed in standard aCSF. The incubation took place in a temperature controlled $\left(37^{\circ} \mathrm{C}\right)$ flow-through chamber, gassed with $\mathrm{O}_{2} / \mathrm{CO}_{2}(95 \% / 5 \%)$ for $90 \mathrm{~min}$. The flow rate of the aCSF was set to $1 \mathrm{~mL} / \mathrm{min}$. Care was taken to ensure that the upper side of the slices was fully exposed to the warm humidified gas mixture, while the underside was lying in aCSF. After the slices had been allowed to recover from the initial preparation stress for $90 \mathrm{~min}$, the flow rate through the chamber was increased to $3 \mathrm{~mL} / \mathrm{min}$ and standard aCSF with low glucose $(2 \mathrm{mM})$ was pumped through for $30 \mathrm{~min}$. This incubation of slices in low glucose aCSF was introduced to produce a prompt depletion of high energy phosphates during Oxygen/glucose deprivation (OGD) (Djuricic et al. 1994).

Oxygen/glucose-deprived aCSF was prepared in the same manner as standard aCSF except for the addition of HEPES and glucose. HEPES was removed from oxygen/glucosedeprived aCSF, since it provides additional buffering capacity. This could influence the decrease in $\mathrm{pH}$ during OGD and alter the tissue response to OGD. Slight changes in osmolarity owing to the removal of glucose and HEPES were compensated by adjusting the $\mathrm{NaCl}$ concentration. Before transferring slices to the anoxic chamber, glucose was washed out of the tissue by immersion of the slices in oxygenated, aglycemic aCSF for 2 min. The post-OGD period was initiated by transferring slices to standard aCSF (IIow rate $1 \mathrm{~mL} / \mathrm{min})$ with $\mathrm{O}_{2} / \mathrm{CO}_{2}(95 \% / 5 \%)$.

In contrast to previously described hippocampal slice models, we used an interface technique in which the upper side of the slices was fully exposed to the warm humidified gas mixture while the underside was lying in aCSF. In addition, the slices were kept in a flow-through chamber and the aCSF was supplemented with amino acids. Using this technique, energy metabolism and protein synthesis can be kept constant for up to $24 \mathrm{~h}$ as shown in a variety of previous studies (Berger et al. 1996; 1998; Djuricic et al. 1994). This; is especially true of slices from mature fetuses, since they are much less vulnerable to the preparation procedure than those from adult animals (Berger et al. 1996; 1998). As shown in a recent study, hippocampal slices from mature fetal guinea pigs are completely depleted of ATP after 20 to $40 \mathrm{~min}$ of OGD. Within $24 \mathrm{~h}$ a partial recovery in the tissue concentration of ATP can be seen. The extent of the recovery ranges from 40 to $90 \%$ of control levels depending on the duration of OGD (Berger et al. 1996; 1998). The histological status of the tissue had been investigated in some pilot experiments. Severe deterioration of the tissue could be excluded after an incubation period of up to $24 \mathrm{~h}$. 


\subsubsection{Experimental protocols}

The experimental protocol included a $210 \mathrm{~min}$ preincubation phase $(180 \mathrm{~min}$ in $10 \mathrm{mM}$ glucose and $30 \mathrm{~min}$ in $2 \mathrm{mM}$ glucose aCSF), an ischemic phase (10-40 min) and a recovery phase ( $12 \mathrm{~h}$ starting from the end of OGD). A separate incubation chamber, equilibrated with $95 \% \mathrm{~N}_{2} / 5 \% \mathrm{CO}_{2}$, was used for the induction of OGD. In contrast to the standard aCSF, the ischemic aCSF contained no glucose or HEPES. HEPES was omitted, because its buffering capacity may influence the fall in $\mathrm{pH}$ accompanying OGD. Before the tissue slices were transferred to the anoxic incubation chamber, they were washed in aglycemic aCSF in order to lower the glucose levels in the tissue still further. During OGD the tissue slices were completely submerged in the aCSF. No additional aCSF was pumped through the chamber during this period (flow rate: $0 \mathrm{~mL} / \mathrm{min}$ ). In the postischemic phase the tissue slices were transferred back to standard aCSF (flow rate: $1 \mathrm{~mL} / \mathrm{min}$ ) and equilibrated with carbogen $\left(95 \% \mathrm{O}_{2} / 5 \% \mathrm{CO}_{2}\right)$. After a recovery period of $12 \mathrm{~h}$ the slices were sampled to measure the tissue concentrations of adenine nucleotides and protein synthesis.

Mild hypothermia (Chapter 8 ) was induced immediately, $2 \mathrm{~h}$ or 4 h after OGD by lowering the incubation temperature to $34^{\circ} \mathrm{C}$ or $31^{\circ} \mathrm{C}$, respectively. The hypothermic period lasted for $12 \mathrm{~h}$. At the end of the experiments tissue concentrations of adenylates and protein synthesis were determined in slices of the control and intervention groups. Each experiment (normothermia vs. hypothermia) consisted of a normothermic control group and a hypothermic group without OGD. In addition, there were three normothermic and three hypothermic groups of slices that underwent OGD (20-40 $\mathrm{min})$.

\subsubsection{Measurements}

The concentrations of adenylates in the tissue slices were measured in the supernatant of neutralized tissue homogenates by high-pressure liquid chromatography after extraction with perchloric acid (Berger et al. 1996). The adenylate energy charge (AEC), a measure of the balance between energy consumption and energy production was calculated as follows (Atkinson 1968): AEC $=([\mathrm{ATP}]+0.5[\mathrm{ADP}]) /([\mathrm{ATP}]+[\mathrm{ADP}]+[\mathrm{AMP}])$. The protein content of the tissue slices was measured by the Lowry method (Lowry et al. 1951).

The rate of incorporation of ${ }^{14} \mathrm{C}$-leucine into tissue proteins was taken as a measure of protein synthesis rate (PSR). For these readings, $30 \mathrm{~min}$ before the conclusion of the experiments the tissue slices were incubated in standard-aCSF supplemented with 5 $\mathrm{mCi} / \mathrm{mL}$ L-( ${ }^{14} \mathrm{C}$ )-leucine (Amersham Buchler, Braunschweig, Germany; specific activity: 
$54 \mathrm{mCi} / \mathrm{mMol})$. The slices remained there for $30 \mathrm{~min}$ and were homogenized in trichloroacetic acid. The radioactivity of the precipitate was measured by liquid scintillation spectrometry after proteins had been dissolved in $1 \mathrm{M} \mathrm{NaOH}$ (Berger et al. 1996).

In a further set of experiments we investigated whether a possible neuroprotective effect of magnesium might be mediated in part through the NO-system. Here we determined the tissue concentrations of cGMP $10 \mathrm{~min}$ after an OGD-period of between 10 and $40 \mathrm{~min}$ using a RIA (NEN, Bad Homburg, Germany). For these measurements tissue slices were frozen in liquid nitrogen and extracted with perchloric acid. As in the first set of experiments, the magnesium concentration in the incubation medium of the study groups was raised from $1.3 \mathrm{mM}$ to $3.9 \mathrm{mM}$ either $2 \mathrm{~h}$ before or immediately after $\mathrm{OGD}$. To confirm that elevated tissue concentrations of cGMP really reflect increased NOproduction, we inhibited NO-synthase with the specific blocker $\mathrm{N}$-nitro-L-arginine (LNNA). L-NNA ( $100 \mu \mathrm{M})$ was added to the incubation medium $30 \mathrm{~min}$ prior to, during and $10 \mathrm{~min}$ after OGD. By these measures the increase of cGMP tissue concentration $10 \mathrm{~min}$ after OGD could be completely suppressed. This observation confirms previous studies showing the same effect (Berger et al. 1998; Paschen 1995).

\subsubsection{Statistics}

The values are presented as means \pm standard deviation. The data for each experimental group was obtained from 4 to 5 tissue slices. We restricted statistical analysis to each single experiment, which consisted of 8 groups of slices, i.e. a normothermic control group, a hypothermic group without OGD as well as three normothermic and three hypothermic groups of slices that underwent OGD (20-40 min). There were no repeat studies in a single preparation and no data was discarded. Significant differences within and between groups were assessed using ANOVA and Scheffé's F-test.

\subsection{REFERENCES}

1. Atkinson DE. The energy charge of the adenylate pool as a regulatory parameter: interaction with feedback, modifiers. Biochemistry 1968;7:4030-34.

2. Berger R, Djuricic B, Jensen A, Hossmann KA, Paschen W. Ontogenetic differences in energy metabolism and inhibition of protein synthesis in hippocampal slices during in vitro ischemia and 24 h of recovery. Dev Brain Res 1996:91:281-9!. 
3. Berger R, Jensen A, Hossmann KA, Paschen W. Effect of mild hypothermia during and after transient in vitro ischemia on metabolic disturbance in hippocampal slices at different stages of development. Dev Brain Res 1998;105:67-77.

4. Berger R, Jensen A, Paschen W. Metabolic disturbances in hippocampal slices of feal guinea pigs during and after oxygen-glucose deprivation: is nitric oxide involved? Neurosci Lett 1998;245:163-66.

5. Berger R, Lehmann T, Karcher J, Garnier Y, Jensen A. Low dose flunarizine protects the fetal brain from ischemic injury in sheep. Pediatr Res 1998;44:1-6.

6. Berger R, Lehmann T, Karcher J, Schachenmayr W, Jensen A. Relation between cerebral oxygen delivery and neuronal cell damage in fetal sheep near term. Reprod Fertil Dev 1996:8:317-321.

7. Brown AW, Brierley JB. Anoxic-ischaemic cell change in rat brain light miçroscopic and fine structural observations. J Neurol Sci 1971:16:59-84.

8. Buckberg GD, Luck JC, Payne DB, Hoffmann JL, Archie JP, Fixler DE. Some sources of error in measuring regional blood flow with radioactive microspheres. J Appl Physiol 1971:31:598-604.

9. Djuricic B, Berger R, Paschen W. Protein synthesis and energy metabolism in hippocampal slices during extended ( 24 hours) recovery following different periods of ischemia. Metab Brain Dis 1994,9.377-89.

10. Heymann MA, Payne BD, Hoffman JIE, Rudolph AM. Blood flow measurements with radionuclide-labeled particles. Prog Cardiovasc Dis 1977;20:55-79.

11. Hossmann K-A, Widmann R, Wiessner Ch, Dux E, Djuricic B, Röhn G. Protein synthesis after global ischemia and selective vulnerability. In: Krieglstein J, Oberpichler-Schwenk H, eds. Pharmacology of Cerebral Ischemia. Stuttgart: Wissenschaftliche Verlagsgeseltschaft mbH, 1992:289-299.

12. Jelinek J, Jensen A. Catecholamine concentrations in plasma and organs of the fetal guinea pig during normoxaemia, hypoxaemia and asphyxia. J Dev Physiol $1991 ; 15: 145-152$.

13. Jensen A, Hohmann M, Künzel W. Dynamic changes in organ blood flow and oxygen consumption during acute asphyxia in fetal sheep. I Dev Physiol 1987;9:543-559.

14. Jensen A, Roman Ch, Rudolph AM. Effects of reducing uterine blood flow on foetal blood flow distribution and oxygen delivery. J Dev Physiol 1991;15:309-323.

15. Lowry OH, Rosenbrough NJ, Farr AL, Randall R. Protein measurement with the folin phenol reagent. J Biol Chem 1951;193:265-275.

16. Paschen W. Comparison of biochemical disturbances in hippocampal slices of gerbil and rat during and after in vitro ischemia. Neurosci Lett 1995;199:41-44.

17. Penny JE, Kukums JR. Tyrer JH, Eadie MJ. Selective vulnerability of the hippocampus to hypoxia: cytophotometric studies of enzyme activity in single neurones. Proc Aust Assoc Neurol 1974:11:177-181. 
18. Rudolph AM, Heymann MA. Circulation of the foetus in utero: Methods for studying distribution of blood flow, cardiac output and organ blood flow. Cire Res 1967;21:163184

19. Tegtmeier F, Dengler K, Zacharias E, Eichhorn R, Höller M. Brain concentrations and effect of cerebroprotective drugs - investigations with flunarizine and R 56865. Preclinical Research Report 1987, Janssen Research Foundation. 
Chapter 3 


\section{Chapter 4}

\section{LOW DOSE FLUNARIZINE DOES NOT AFFECT SHORT TERM FETAL CIRCULATORY RESPONSES TO ACUTE ASPHYXIA IN SHEEP NEAR TERM}

Garnier Y, Berger R, Pfeiffer, D, Jensen A

Reproduction, Fertility and Development, 1998;10:405-411 


\section{ABSTRACT}

Asphyxia is one of the major causes of perinatal brain damage and neuronal loss that may result in psycho-motor deficits during later development. As shown previously the immature brain can be protected from ischemic injury by flunarizine, a class IV calcium antagonist. However, cardiovascular side-effects of flunarizine, when applied at dosages used in those studies, have been reported. Recently, we were able to demonstrate that even by injecting flunarizine at a far lower dosage ( $1 \mathrm{mg} / \mathrm{kg}$ estimated body weight) neuronal cell damage, caused by occlusion of both carotid arteries for $30 \mathrm{~min}$, can be reduced in fetal sheep near term. The aim of the present study was, therefore, to examine whether low dose flunarizine affects fetal cardiovascular responses to acute asphyxia in sheep near term. Ten fetal sheep were chronically instrumented at a mean gestational age of $132 \pm 1$ days (term is at 147 days). Fetuses from the study group received a bolus injection of flunarizine (1mg/kg estimated fetal weight) $60 \mathrm{~min}$ before asphyxia, while the solvent was administered to the fetuses from the control group. Organ blood flows, physiological variables and plasma concentrations of catecholamines were measured before, during and after a single occlusion of uterine blood flow for $2 \mathrm{~min}$, i.e., at $0,1,2,3,4$, and $30 \mathrm{~min}$. Before asphyxia distribution of combined ventricular output, physiological variables as well as concentrations of catecholamines in fetuses from the control group were in the normal range for chronically prepared fetal sheep near term. During acute asphyxia there was a redistribution of cardiac output towards the central organs accompanied by a pronounced bradycardia and a rapid increase in arterial blood pressure. After asphyxia circulatory centralization did not resolve quite as rapidly as it developed, but was almost completely recovered at $30 \mathrm{~min}$ after the insult. There were nearly no differences in the time course of physiological and cardiovascular variables measured before, during and after acute intrauterine asphyxia between control and study group. From the present study we conclude that low dose flunarizine does not affect short term fetal circulatory responses to acute asphyxia in sheep near term. 


\section{INTRODUCTION}

Asphyxia is one of the major causes of perinatal brain damage that may result in psychomotor deficits during later development (Volpe, 1995). During hypoxia-ischemia a variety of pathological mechanisms are triggering intracellular accumulation of calcium that may induce neuronal cell death (Krieglstein, 1988). Pharmacological interventions that act by limiting intracellular calcium influx during hypoxia-ischemia seems to be effective in reducing neuronal degeneration (Krieglstein and Oberpichler-Schwenk, 1994). In previous studies pretreatment by flunarizine, a class IV calcium antagonist, has been shown to protect the brain of immature animals from hypoxic-ischemic injury (Chumas et al., 1993; Gunn et al., 1989; Gunn et al., 1994; Silverstein et al., 1986; Van Reempts et al., 1993). However, the actual dose of flunarizine must be considered, because dose-dependent cardiovascular side-effects have been observed. After infusion of $45 \mathrm{mg}$ flunarizine Gunn and colleagues reported severe hypotension and bradycardia followed by fetal demise in 3 of 8 fetal sheep near term (Gunn et al., 1994). Flunarizine was also toxic when given to sick fetuses (Gunn et al., 1988). These pharmacological side-effects preclude the inititation of clinical studies. However, it has been shown previously that the therapeutic dosage of flunarizine is far below that used in the studies mentioned above (Todd et al., 1989). By i.v. injection of flunarizine at low dlosage $(1 \mathrm{mg} / \mathrm{kg}$ estimated body weight $)$ fetal sheep near term could be protected from neuronal cell damage caused by occlusion of both carotid arteries for $30 \mathrm{~min}$ (Berger et al., 1998). The aim of the present study was, therefore, to examine whether low dose flunarizine effects the circulatory and neurohumoral responses to acute asphyxia in fetal sheep near term. In addition, we determined the time course of flunarizine concentrations in fetal plasma and brain under these experimental conditions. A brief account of this study has been published elsewhere (Berger et al., 1998).

\section{METHODS}

\section{Animal preparation}

Ten fetal sheep were chronically prepared at a mean gestational age of $132 \pm 1$ days (term. is at 147 days). Mean gestational age of untreated fetuses was somewhat higher than that of

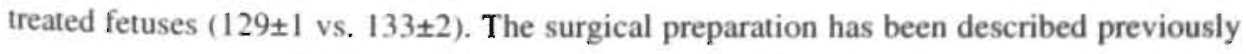
(Jensen et al, 1987). Briefly, all ewes were anesthetized by subarachnoid injection of $8 \mathrm{ml}$ of $0.75 \%(w / v)$ bupivacaine at the lower spine, and were operated on under sterile conditions. Polyvinyl catheters were placed into a maternal iliac artery and vein through tibial vessels. The ewe's abdominal wall was opened in the midline and a snare was placed around the descending aorta below the renal artery, which was then used to arrest uterine 
and ovarian blood flow during the experiment. Care was taken not to include any nerves. Fetal catheters were inserted and maintained as described previously (Jensen et al., 1987). An additional catheter was placed into the amniotic cavity. All catheters were filled with heparin $(1,000 \mathrm{IU} / \mathrm{ml})$, plugged, and passed subcutaneously to the ewe's flank, where they were exteriorized and protected by a pouch sewn to the skin. On the day of surgery and each day thereafter, the ewe received 2 million units of penicillin G (Grünenthal, Germany) and $80 \mathrm{mg}$ of gentamycin sulfate (Merck, Germany), half intravenously and half into the amniotic cavity. The fetuses were allowed to recover for 2 days before being studied.

\section{Experimental protocol}

After control measurements of the physiological variables, 5 out of 10 fetuses were treated by a bolus injection (at $-60 \mathrm{~min}$ ) of flunarizine ( $1 \mathrm{mg} / \mathrm{kg}$ estimated fetal weight), while the remaining received the solvent. The drugs were donated by Janssen Pharmaceutica, Beerse, Belgium. Sixty minutes later (at $0 \mathrm{~min}$ ) uterine blood flow was arrested by a single occlusion of the descending aorta for $2 \mathrm{~min}$ to induce acute fetal asphyxia. To determine the effects of flunarizine on the time course of circulatory centralization before, during and after acute asphyxia, blood flow to fetal organs and the distribution of combined ventricular output were measured by injecting six batches of differently labeled isotope microspheres $\left({ }^{141} \mathrm{Ce},{ }^{114} \mathrm{In},{ }^{113} \mathrm{Sn},{ }^{102} \mathrm{Ru},{ }^{95} \mathrm{Nb} \&{ }^{46} \mathrm{Sc}, 16 \mu \mathrm{m}\right.$ diam., New England Nuclear) into the inferior vena cava (Heymann et al, 1977: Rudolph and Heymann, 1967). Asphyxia was caused by arrest of uterine blood flow with the snare. The first 5 microsphere injections were made at short intervals, i.e. 75 s before (control measurement, at $-1 \mathrm{~min})$, at 1 and $2 \mathrm{~min}$ during the arrest of uterine blood flow, and at 1, 2, and $28 \mathrm{~min}$ after the release of the snare (recovery period). The experimental protocols were approved by the appropriate institutional review committee and meet the guidelines of the responsible governmental agency.

\section{Measurements}

Fetal heart rate and arterial blood pressure, amniotic fluid pressure, and maternal arterial blood pressure were recorded on a polygraph (Hellige, Germany) during the experiment. Complete occlision of the ewe's descending aorta by the snare throughout the 2-min study period was confirmed by the fall in pressure distal to the obstruction. Before blood flow was measured a blood sample was taken from the descending aorta and analysed for blood gases, acid-base balance (278 Blood Gas System, Ciba Corning. Frankfurt, Germany). hemoglobin concentration, oxygen saturation (OSM 2 Hemoximeter, Radiometer, 
Copenhagen, Denmark), glucose, lactate, catecholamine and flunarizine concentrations. Plasma concentrations of both catecholamines and flunarizine and brain tissue concentrations of flunarizine were determined by reversed phase ion-pair High Performance Liquid Chromatography with electrochemical detection (HPLC-ECD), with a detection limit of $5 \mathrm{pg}$, an intra-assay variance below $5 \%$, and an inter-assay variance below 10\%. A detailed description of the HPLC-ECD catecholamine assay is given elsewhere (Jelinek and Jensen, 1991; Tegtmeier et al., 1987).

After the experiment a lethal dose of sodium pentobarbitone was given to the ewe and the fetuses were perfused with $300 \mathrm{ml}$ of formalin ( $15 \%$, w/v, saline). Fetal organs and cotyledons were weighed and placed in vials, which were filled to the same height to reduce variations in geometry. The intestines were separated from the mesentery, opened, and cleared of contents. Paired organs (lungs, kidneys, and adrenals) were counted separately, as were the right and left sides of the cerebrum and of the brainstem regions. No significant preferential streaming of microspheres was found. Specimens of skin and muscle were taken from the hips and shoulders of each side. There were no differences in blood flow between the intact side and the side on which the femoral or brachial arteries were catheterized. Upper and lower carcass were carbonized and the aliquots filled into vials. The applied solid-state semi-conductor germanium (Ge) gamma counter had a high energy resolution of about $3 \mathrm{keV}$ and was connected to a multichannel (2048) pulse height analyzer (ND 62, Nuclear Data Inc., Illinois, USA). The results were normalized with respect to time and sample weight.

\section{Calculations}

Fetal combined ventricular output and blood flow to the various organs were calculated from counts of the injected nuclide recovered in fetal organs or placenta, from counts in the appropriate reference samples, and from the withdrawal rate of the reference sample (Heymann et al., 1977; Rudolph and Heymann, 1967). Portal venous blood flow was calculated by summing the actual blood flow to all gastro-intestinal organs, including stomach, intestines, mesentery, pancreas, and spleen. The percentage of combined ventricular output distributed to a given organ was calculated from the absolute blood flow to that organ and the combined ventricular output. The vascular resistance was calculated by dividing arterial blood pressure (corrected for amniotic fluid pressure) by blood flow and was expressed in $\mathrm{mmHg} / \mathrm{ml} / \mathrm{min} / 100 \mathrm{~g}$ of tissue. Blood flow inferior to $1 \mathrm{ml} / \mathrm{min} / 100 \mathrm{~g}$ was treated as 1. Umbilical vascular resistance $(\mathrm{mmHg} / \mathrm{ml} / \mathrm{min} / \mathrm{kg}$ fetal weight) was calculated by dividing the perfusion pressure of the umbilical circulation (anterial blood pressure minus the estimated umbilical venous blood pressure before ( $11 \mathrm{mmHg}$ ) and 
during (17 $\mathrm{mmHg}$ ) reduction in uterine blood flow (Jensen, Roman and Rudolph, 1991)) by umbilical blood flow.

\section{Statistics}

Results are given as means \pm SEM. The data were analysed for intra- and intergroup differences by two-way multivariate analysis of variance for repeated measures. GamesHowell-test was used as a post-hoc testing procedure. Statistical analysis was performed by Super Anova Statistical Package (Abacus, Inc. Ca., USA).

\section{RESULTS}

\section{Control group}

In the control period combined ventricular output, heart rate, arterial blood pressure, blood gases, pH, glucose, lactate and plasma concentrations of catecholamines were in the normal range for chronically prepared fetal sheep near term (Jensen and Berger, 1991). Arrest of uterine blood flow for 2 min decreased fetal heart rate, arterial $\mathrm{O}_{2}$ saturation of hemoglobin, and $\mathrm{pH}$, and increased fetal arterial blood pressure, $\mathrm{pCO}_{2}$, lactate, and plasma concentrations of catecholamines (Tables 1 and 2).

After I min of asphyxia combined ventricular output fell by $48 \%$, however, the portion distributed to placenta and heart increased by $57 \%$ and $431 \%$, respectively, whereas that to both the adrenals and total brain did not change significantly (Tables 2 and 4). There was an uneven distribution of combined ventricular output to the various regions of the brain during asphyxia. The portion distributed to some of the lower areas of the brain increased progressively after I min asphyxia, whereas that to the cerebrum did not change, and that to the choroid plexus decreased (data not shown).

After $2 \mathrm{~min}$ of asphyxia combined ventricular output was reduced by $56 \%$ (Table 2), but its redistribution towards central organs resulted in significant increases, in blood flow to the heart $(78 \%)$, midbrain $(60 \%)$, medulla $(91 \%)$, no significant change in blood flow to the adrenals and cerebrum, and a decrease in that to the choroid plexus (Table 3). 
Table 1. Acid-Base Balance, Blood Gases, and Catecholamine Concentrations in Control and Treated (Flunarizine) Fetuses Near Term.

\begin{tabular}{|c|c|c|c|c|c|c|c|c|c|c|c|}
\hline Groups & Control & Asphyxia 1 & & Asphyxia 2 & & Recevery 3 & & Recevery 4 & & Recevery 30 & \\
\hline \multicolumn{12}{|l|}{ pH } \\
\hline $\mathrm{c}$ & $7,40+0,01$ & $7,38+0,00$ & & $2,30 \neq 0,00$ & $d$ & $7,28=0,00$ & - & $7,30 * 0,00$ & $d$ & $7,33 * 0.02$ & \\
\hline$F$ & $7,39+0,03$ & $7,36=0.02$ & & $7,28+0.03$ & $\bullet$ & $7,26+0,03$ & e & $7,28+0.02$ & d & $7,32+0,04$ & \\
\hline \multicolumn{12}{|c|}{ Oxyrea Saturatien (\%) } \\
\hline $\mathrm{C}$ & $5,0.0=3,6$ & $14,2=3.9$ & f & $4,8+1,8$ & r & $25,7+5,2$ & f & $43,2 * 4,0$ & & $48,8+4,9$ & \\
\hline $\boldsymbol{F}$ & $54,5 * 4,8$ & $14,0=2,9$ & f & $3,4 \neq 0,4$ & f & $26,8+4,2$ & f & $38.4+3.9$ & $e$ & $47,3=4,5$ & \\
\hline \multicolumn{12}{|c|}{$\mathrm{pO}_{2}(\mathrm{mmHg})$} \\
\hline C & $21,8+1.2$ & $10,2+1,2$ & f & $5,5+1,0$ & f & $16.9 \cdot 2.2$ & a & $23,6 \div 1,0$ & & $24,3+1,3$ & \\
\hline$F$ & $21,3=1,8$ & $9.5 \div 1.4$ & f & $3.9+0.3$ & f & $15,9+1,4$ & 4 & $19,7 \div 1,3$ & & $21,9+1,9$ & \\
\hline \multicolumn{12}{|c|}{$\mathrm{pCO}_{1}(\mathrm{~mm} \mathrm{H} \mathrm{g}$} \\
\hline $\mathrm{C}$ & $47,4+1,2$ & $51,4=1,3$ & f & $62,8+2,8$ & f & $63,9+4,1$ & f & $57.9+3.0$ & & $50,0+1,4$ & \\
\hline $\mathbf{F}$ & $47.3 \pm 1.8$ & $50,4=1,2$ & f & $64,8+3,1$ & f & $62,9+2,9$ & f & $56.8+2.0$ & e & $47,7+2,0$ & \\
\hline \multicolumn{12}{|c|}{ Glecese (moini) } \\
\hline C & $21,4=2,0$ & $21,8+1,9$ & & $19,0+1,0$ & & $21,0 * 1,6$ & & $23,4 * 2,0$ & & $28,8+2,7$ & d \\
\hline $\mathbf{F}$ & $21,0+1,3$ & $21,8+2,6$ & & $16.8+2,1$ & & $18,0=2,1$ & & $23,5 * 2,5$ & & $28,4+4,3$ & 4 \\
\hline \multicolumn{12}{|c|}{ Lactate (mmell) } \\
\hline c & $1,64+0,10$ & $1,74=0,10$ & & $2,78+0,20$ & & $3,63 \neq 0,30$ & & $3,60 \div 0,00$ & & $4,42+0,37$ & d \\
\hline$F$ & $2,80+0,74$ & $2,90 \div 0,74$ & & $3,95+0,90$ & & $4,83=0,77$ & & $4,50 * 0,66$ & & $3,91 * 1,49$ & d \\
\hline \multicolumn{12}{|c|}{ Nerepinephrine (pe/min) } \\
\hline c & $34 !+67$ & $7150=2452$ & & $50089=12568$ & f & $33263 \neq 10507$ & $\epsilon$ & $12635=3791$ & & $2014 \div 786$ & \\
\hline F & $815 \neq 479$ & $12510=4421$ & & 73256 * 15863 & $a, f$ & $43646 \div 10064$ & f & $26233 \div 11605$ & d & $6425 * 5621$ & \\
\hline \multicolumn{12}{|c|}{ Epineplarine (pe/mI) } \\
\hline c & $47=16$ & $1171=184$ & & $31794 \pm 6207$ & f & $14561+3906$ & c & $7549 \neq 1702$ & & $903+682$ & \\
\hline F & $47 \pm 18$ & $2626 \neq 1141$ & & $34815 \neq 6440$ & i & $17164=4420$ & f & $10993+4578$ & $d$ & $2838+2776$ & \\
\hline \multicolumn{12}{|c|}{ Dopamine (pe/ml) } \\
\hline C & $58 \pm 17$ & $247 \pm 94$ & & $1402+637$ & $d$ & $749=439$ & & $254=109$ & & $150+74$ & \\
\hline $\mathbf{F}$ & $63 \pm 26$ & $825 \pm 357$ & & $4085 \pm 1014$ & $c, f$ & $1592=486$ & $c$ & $660 \div 312$ & & $432+372$ & \\
\hline
\end{tabular}

a $<0.05, b<0.01, c<0.001$ significant between groups; $d<0.05,-<0.01, f<0.001$ significant vernus control withit groups $\mathrm{C}=\mathrm{control}$ fetuses $(\mathrm{n}-5), \mathrm{F}=$ treated (flunarizine) fetuses $(\mathrm{n}=5)$

In the immediate recovery period, i.e. 1 and 2 min after arrest of uterine blood flow had been released, arterial blood pressure was still high (Table 2) and blood flow to the heart and all parts of the brain except for the choroid plexus increased (Table 3). At $30 \mathrm{~min}$, i.e. after $28 \mathrm{~min}$ recovery, these values were not different from control. 
In all peripheral organs of the upper and lower body segment, including carcass, skeletal muscle, total gastro-intestinal tract and portal vein, kidneys, spleen, scalp, and body skin, the proportion of combined ventricular output and actual blood flow decreased to very low values during asphyxia, and recovered gradually thereafter (Tables 2 and 3). During asphyxia a pronounced increase in plasma concentrations of catecholamines could be observed that returned to control at the end of the recovery period (Table 1).

Table 2. Changes of Physiologic Variables and Blood Flows in Control and Treated (Flunarizine) Fetuses Near Term.

\begin{tabular}{|c|c|c|c|c|c|c|c|c|c|c|}
\hline Groups & S Controi & Asphyxia 1 & & Asphyxia 2 & & Recovery 3 & & Recovery 4 & & Recovery 30 \\
\hline \multicolumn{5}{|c|}{ Fetal Heart Rate (bpm) } & d & $152,2 \pm 35,6$ & & $158.4 \pm 17.0$ & & $196.5 \pm 44.6$ \\
\hline F & $153,8 \neq 12,7$ & $76,4=13,9$ & e & $87,8=14,8$ & d & $150,1=28,0$ & & $137.6=4.9$ & & $178,8=16,8$ \\
\hline \multicolumn{2}{|c|}{ Arterlal blood pressure (mmllg) } & $\frac{\operatorname{mill}}{57,7}=28$ & & $71,7 \neq 5.9$ & d & $80,2=5,6$ & $\mathrm{r}$ & $73,9 \pm 3,2$ & e & $48.5 \pm 2.5$ \\
\hline f & $49.6 \pm 2.7$ & $50,8=4,6$ & & $69.0=4.6$ & d & $74,1=11,2$ & d & $78.1 \neq 1,9$. & $f$ & $64,8=11,9$ \\
\hline
\end{tabular}

Blood nows (mVmin $\times \mathrm{kg}$ fetus)

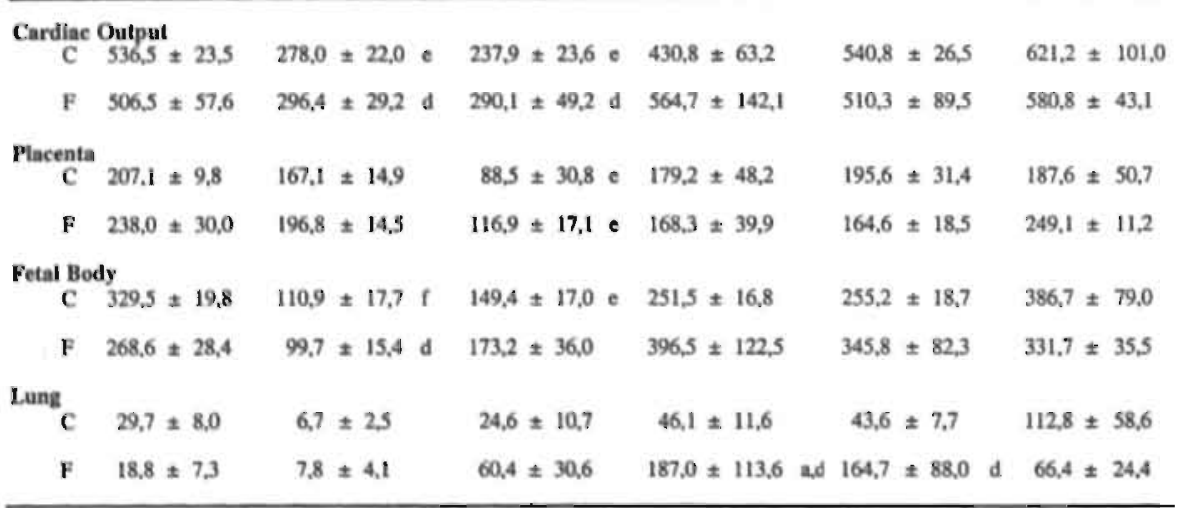

R.Cardiac Output

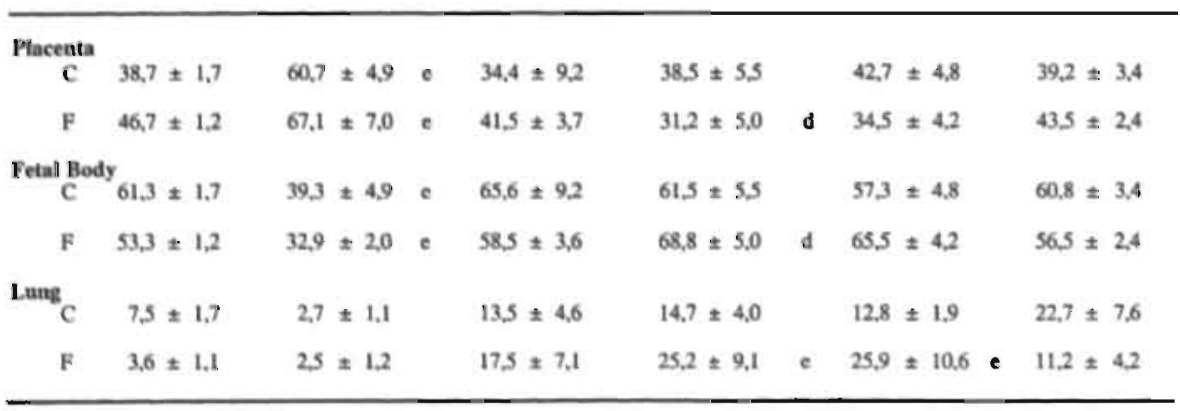

ac0.05, b<0.01, c<0.001 significant between groups; d $<0.05$, ec0.01, f<0.001 significant versus control within groups $\mathrm{C}=$ control fetuses $(\mathrm{n}=5)$, $\mathrm{F}=$ treated (flunarizine) fetuses $(\mathrm{n}=5)$ 
Table 3. Organ Blood Flows in Control and Treated (Flunarizine) Fetuses Near Term

Blood flow (mL/min s 100g)

\begin{tabular}{|c|c|c|c|c|c|c|c|c|c|c|c|c|}
\hline & Group & Centrol & Asphyxia I' & & Asphyxia 2' & & Recovery $y$ & & Recovery 4 & & Recovery $30^{\circ}$ & $\mathrm{P}$ \\
\hline Heart & $\begin{array}{l}\mathrm{C} \\
\mathrm{F}\end{array}$ & $\begin{array}{l}216 \pm 31 \\
207 \pm 26\end{array}$ & $\begin{array}{l}616 \pm 131 \\
432 \pm 105\end{array}$ & $\varepsilon$ & $\begin{array}{l}385 \pm 118 \\
749 \pm 65\end{array}$ & $\begin{array}{l}\mathrm{f} \\
\mathrm{f}\end{array}$ & $\begin{array}{l}905 \pm 144 \\
752 \pm 112\end{array}$ & f & $\begin{array}{l}693 \pm 104 \\
634 \pm 88\end{array}$ & e & $\begin{array}{l}419=103 \\
525 \div 97\end{array}$ & d \\
\hline Brain & $\begin{array}{l}\mathrm{C} \\
\mathrm{F}\end{array}$ & $\begin{array}{l}206 \pm 12 \\
128 \pm 21\end{array}$ & $\begin{array}{l}200 \pm 24 \\
127 \pm 22\end{array}$ & & $\begin{array}{l}231 \pm 20 \\
159 \pm 25\end{array}$ & & $\begin{array}{l}362 \pm 25 \\
282 \pm 51\end{array}$ & $\begin{array}{l}f \\
f\end{array}$ & $\begin{array}{l}345=15 \\
265=51\end{array}$ & e & $\begin{array}{l}188 \div 24 \\
189 \pm 43\end{array}$ & 0.05 \\
\hline Cerebrum & $\begin{array}{l}\mathrm{C} \\
\mathrm{F}\end{array}$ & $\begin{array}{l}187 \pm 13 \\
129 \geq 9 a\end{array}$ & $\begin{array}{l}159=18 \\
108=7\end{array}$ & & $\begin{array}{l}182=13 \\
129=19\end{array}$ & & $\begin{array}{l}311=24 \\
262 \geq 29\end{array}$ & $\begin{array}{l}f \\
f\end{array}$ & $\begin{array}{l}297 \div 17 \\
248 \div 29\end{array}$ & $\begin{array}{l}f \\
f\end{array}$ & $\begin{array}{l}167+21 \\
186 \pm 23\end{array}$ & \\
\hline Cerebellum & $\begin{array}{l}\mathrm{C} \\
\mathrm{F}\end{array}$ & $\begin{array}{l}237 \pm 8 \\
168 \pm 37\end{array}$ & $\begin{array}{l}270 \pm 30 \\
190 \pm 28\end{array}$ & & $\begin{array}{l}302 \pm 26 \\
236 \pm 28\end{array}$ & & $\begin{array}{l}463 \pm 41 \\
354=41\end{array}$ & $\begin{array}{l}\text { f } \\
\text { at }\end{array}$ & $\begin{array}{l}446=18 \\
353 \neq 56\end{array}$ & f & $\begin{array}{l}241 \geq 40 \\
263 \pm 61\end{array}$ & \\
\hline Brainstem & $\begin{array}{l}\mathrm{C} \\
\mathrm{F}\end{array}$ & $\begin{array}{l}282 \pm 17 \\
205 \pm 28\end{array}$ & $\begin{array}{l}385=52 \\
294 \pm 33\end{array}$ & & $\begin{array}{l}461=50 \\
390 \pm 24\end{array}$ & $\begin{array}{l}d \\
d\end{array}$ & $\begin{array}{l}594=30 \\
578 \neq 94\end{array}$ & $\begin{array}{l}\mathrm{f} \\
\mathrm{f}\end{array}$ & $\begin{array}{l}567 \pm 26 \\
538 \pm 61\end{array}$ & $\begin{array}{l}f \\
f\end{array}$ & $\begin{array}{l}267=33 \\
331=77\end{array}$ & \\
\hline Choroid plexus & $\underset{F}{C}$ & $\begin{array}{l}556 \pm 82 \\
576 \pm 81\end{array}$ & $\begin{array}{l}79 \pm 13 \\
78 \pm 16\end{array}$ & f & $\begin{array}{l}72 \pm 4 \\
90 \pm 20\end{array}$ & $\begin{array}{l}\text { f } \\
\text { f }\end{array}$ & $\begin{array}{l}130 \pm 25 \\
213 \pm 57\end{array}$ & $\begin{array}{l}\mathrm{f} \\
\mathrm{e}\end{array}$ & $\begin{array}{l}121 \pm 25 \\
300 \pm 115\end{array}$ & $\begin{array}{l}\text { f } \\
d\end{array}$ & $\begin{array}{l}460 \pm 97 \\
722 \pm 209\end{array}$ & $a$ \\
\hline Hippocampus & $\begin{array}{l}\mathrm{C} \\
\mathrm{F}\end{array}$ & $\begin{array}{l}176 \pm 19 \\
121 \pm 12\end{array}$ & $\begin{array}{l}197 \pm 26 \\
126=14\end{array}$ & & $\begin{array}{l}239 \pm 21 \\
173 \pm 21\end{array}$ & & $\begin{array}{l}336=20 \\
344=54\end{array}$ & $\begin{array}{l}f \\
\text { f }\end{array}$ & $\begin{array}{l}313 \pm 29 \\
317 \pm 34\end{array}$ & i & $\begin{array}{l}201 \pm 33 \\
168 \div 43\end{array}$ & \\
\hline Medulla & $\begin{array}{l}C \\
F\end{array}$ & $\begin{array}{l}282 \pm 22 \\
217 \pm 32\end{array}$ & $\begin{array}{l}456 \pm 78 \\
375 \pm 47\end{array}$ & $d$ & $\begin{array}{l}539 \pm 74 \\
503 \pm 38\end{array}$ & e & $\begin{array}{l}650 \pm 31 \\
603 \pm 74\end{array}$ & f & $\begin{array}{l}631 \geq 43 \\
612 \pm 87\end{array}$ & f & $\begin{array}{l}263=29 \\
411=85\end{array}$ & d \\
\hline Midbrain & $\begin{array}{l}\mathrm{C} \\
\mathrm{F}\end{array}$ & $\begin{array}{l}323 . \pm 20 \\
226 \pm 32\end{array}$ & $\begin{array}{l}432 \pm 60 \\
312 \pm 36\end{array}$ & & $\begin{array}{l}515 \pm 59 \\
412 \pm 41\end{array}$ & $\begin{array}{l}d \\
d\end{array}$ & $\begin{array}{l}650 \pm 40 \\
638 \pm 123\end{array}$ & $\begin{array}{l}f \\
f\end{array}$ & $\begin{array}{l}620 \pm 33 \\
579 \pm 59\end{array}$ & i & $\begin{array}{l}282 \pm 40 \\
343 \pm 83\end{array}$ & \\
\hline Adrenal & $\begin{array}{l}\text { C } \\
\text { F }\end{array}$ & $\begin{array}{l}241 \pm 64 \\
470 \pm 122\end{array}$ & $\begin{array}{l}338 \pm 125 \\
448 \pm 110\end{array}$ & & $\begin{array}{l}532 \pm 200 \\
642 \pm 112\end{array}$ & & $\begin{array}{l}546 \pm 156 \\
677 \pm 266\end{array}$ & & $\begin{array}{l}539 \pm 126 \\
653 \pm 170\end{array}$ & & $\begin{array}{l}444 \pm 157 \\
500 \pm 123\end{array}$ & \\
\hline Kidney & $\begin{array}{l}\mathrm{C} \\
\mathrm{F}\end{array}$ & $\begin{array}{l}1801 \pm 36 \\
198 . \pm 22\end{array}$ & $\begin{array}{l}3 \sharp \pm 5 \\
47 \pm 13\end{array}$ & 1 & $\begin{array}{r}10 \pm 4 \\
6 \pm 2\end{array}$ & $\begin{array}{l}\text { f } \\
\text { f }\end{array}$ & $\begin{array}{l}40 \pm 9 \\
63 \pm 15\end{array}$ & $\begin{array}{l}f \\
f\end{array}$ & $\begin{array}{l}69 \pm 7 \\
57 \pm 5\end{array}$ & f & $\begin{array}{l}163 \pm 18 \\
171 \pm 15\end{array}$ & \\
\hline GI traci & $\begin{array}{l}\mathrm{C} \\
\mathbf{F}\end{array}$ & $\begin{array}{l}83 \pm 8 \\
69 \pm 22\end{array}$ & $\begin{array}{l}2.3 \pm 0.8 \\
3.1 \pm 1.5\end{array}$ & $\begin{array}{l}f \\
f\end{array}$ & $\begin{array}{l}6.4 \pm 2.5 \\
4.6 \pm 1.2\end{array}$ & $\begin{array}{l}\mathrm{f} \\
\mathrm{f}\end{array}$ & $\begin{array}{l}39.5 \pm 7 \\
79.4 \pm 15\end{array}$ & $\begin{array}{l}\mathrm{e} \\
\mathrm{a}\end{array}$ & $\begin{array}{l}50,3 \pm 3 \\
52,6 \pm 12\end{array}$ & $d$ & $\begin{array}{l}82.1 \pm 20,2 \\
67.9 \pm 16,6\end{array}$ & \\
\hline Liver, arterial & $\underset{\mathrm{F}}{\mathrm{C}}$ & $\begin{array}{r}5 \pm 2 \\
15 \pm 6\end{array}$ & $\begin{array}{l}2,1 \pm 1.2 \\
1,7 \pm 0,7\end{array}$ & $d$ & $\begin{array}{l}7,6 \pm 3,4 \\
5,0 \pm 3,9\end{array}$ & & $\begin{array}{r}7,1: 2.7 \\
12.8 \pm 5.8\end{array}$ & & $\begin{array}{r}5.3 \pm 1.6 \\
15.3 \pm 6,4\end{array}$ & & $\begin{array}{l}4,4 \pm 1,7 \\
5,9 \pm 3,2 .\end{array}$ & \\
\hline Portal Vein & $\begin{array}{l}\mathrm{C} \\
\mathrm{F}\end{array}$ & $\begin{array}{l}87 \pm 8 \\
82 \pm 21\end{array}$ & $\begin{array}{l}2,3 \pm 0,7 \\
3,0 \pm 1,3\end{array}$ & f & $\begin{array}{l}6,4 \pm 2,4 \\
4,4 \pm 1,2\end{array}$ & f & $\begin{array}{l}39.9 \pm 8 \\
80.2 \pm 15\end{array}$ & $\begin{array}{l}\mathrm{e} \\
\mathrm{a}\end{array}$ & $\begin{array}{l}51.7 \pm 1.6 \\
55,8 \pm 10\end{array}$ & $d$ & $\begin{array}{l}90.7 \pm 20.5 \\
81.4 \pm 19.4\end{array}$ & \\
\hline Spleen & $\underset{\mathrm{F}}{\mathrm{C}}$ & $\begin{array}{l}215 \pm 116 \\
207 \pm 60\end{array}$ & $\begin{array}{l}0.4 \pm 0.2 \\
2.2 \pm 1.2\end{array}$ & e & $\begin{array}{l}4,3 \pm 1,1 \\
3,3 \pm 1,9\end{array}$ & e & $\begin{array}{l}36.3 \pm 22 \\
86.7 \pm 24\end{array}$ & e & $\begin{array}{l}67.3 \pm 32 \\
66.5 \pm 22\end{array}$ & $d$ & $\begin{array}{l}252 \pm 59,1 \\
222 \pm 64,4\end{array}$ & \\
\hline Skeletal muscle & $\begin{array}{l}\text { C } \\
\text { F }\end{array}$ & $\begin{array}{l}19 \pm 3 \\
13 \pm 3\end{array}$ & $\begin{array}{l}1.3 \pm 0.4 \\
0.3 \pm 0.1\end{array}$ & $\begin{array}{l}f \\
f\end{array}$ & $\begin{array}{l}2.3 \pm 0.5 \\
0.5 \pm 0.2\end{array}$ & $\begin{array}{l}f \\
f\end{array}$ & $\begin{array}{l}2.6 \pm 0.9 \\
8.2 \pm 3.5\end{array}$ & $f$ & $\begin{array}{l}3.8 \pm 0.8 \\
1.5 \pm 0.5\end{array}$ & f & $\begin{array}{r}12.0 \pm 3.4 \\
9.7 \pm 2,1\end{array}$ & d \\
\hline Body skin & $\begin{array}{l}\mathrm{C} \\
\mathrm{F}\end{array}$ & $\begin{array}{l}35 \pm 1 \\
20 \pm 5\end{array}$ & $\begin{array}{l}1.5 \pm 0.8 \\
0.9 \pm 0.2\end{array}$ & $\begin{array}{l}f \\
f\end{array}$ & $\begin{array}{l}4.5 \pm 1.1 \\
0.9 \pm 0.3\end{array}$ & f & $\begin{array}{l}17,7 \pm 3,8 \\
11,5 \pm 2,7\end{array}$ & $\begin{array}{l}f \\
d\end{array}$ & $\begin{array}{r}19,0 \pm 2,6 \\
9.9 \pm 3.3\end{array}$ & $\begin{array}{l}f \\
\text { add }\end{array}$ & $\begin{array}{l}22,4 \pm 4,7 \\
17,8 \pm 4,3\end{array}$ & $\stackrel{e}{0.05}^{e}$ \\
\hline Scalp & $\begin{array}{l}\text { C } \\
\text { F }\end{array}$ & $\begin{array}{l}47 \pm 8 \\
32 \pm 8\end{array}$ & $\begin{aligned} 26,0 & \pm 10 \\
9.0 & \pm 2.0\end{aligned}$ & $\begin{array}{l}d \\
a, e\end{array}$ & $\begin{aligned} 13,3 & \pm 3.9 \\
3,7 & \pm 1.3\end{aligned}$ & $\begin{array}{l}f \\
f\end{array}$ & $\begin{array}{l}9.5 \pm 1.8 \\
9.9 \pm 1.2\end{array}$ & $\begin{array}{l}f \\
e\end{array}$ & $\begin{array}{r}12.0 \pm 1,5 \\
3.4 \pm 2.2\end{array}$ & $\begin{array}{l}\text { f } \\
\text { f }\end{array}$ & $\begin{array}{l}16.2 \pm 3,1 \\
35,9 \pm 9.4\end{array}$ & $\begin{array}{l}f \\
a\end{array}$ \\
\hline Careass: & $\begin{array}{l}\mathrm{C} \\
\mathrm{F}\end{array}$ & $\begin{array}{l}27 \pm 2 \\
20 \pm 3\end{array}$ & $\begin{array}{l}3.5 \pm 0.6 \\
2.3 \pm 0.2\end{array}$ & f & $\begin{array}{l}3.2 \pm 0.3 \\
3.2 \pm 0.6\end{array}$ & $\begin{array}{l}\mathrm{f} \\
\mathrm{f}\end{array}$ & $\begin{array}{l}9.3 \pm 1.2 \\
8.3 \pm 1.2\end{array}$ & $\begin{array}{l}f \\
f\end{array}$ & $\begin{array}{r}10.9 \pm 0.7 \\
7.0 \pm 1.3\end{array}$ & f & $\begin{array}{l}16.9 \pm 2.6 \\
18.9 \pm 4.0\end{array}$ & f \\
\hline
\end{tabular}

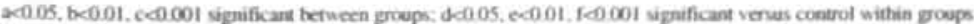

$\mathrm{C}=$ control fetuses $(\mathrm{n}=5$ ). $\mathrm{F}=$ treated (flunarizine i fetures in=5) 


\section{Study group}

Under control conditions there were no significant differences in physiological variables and combined cardiac output between groups (Tables 1-3). Blood flow to the cerebrum, skeletal muscle, body skin and carcass as well as distribution of combined cardiac output to the gastrointestinal tract were somewhat lower in the treated fetuses (Table 3). Responses of physiological and cardiovascular variables to acute intrauterine asphyxia were almost identical in both groups except for blood flow to the scalp, distribution of the combined cardiac output to the cerebrum and scalp, and vascular resistance of the placenta (Tables 2,3). The increase in plasma concentrations of catecholamines in treated fetuses was more pronounced than in the control group (Table 1). Above all the dopamine concentration during asphyxia was significantly higher in the treated fetuses. During the immediate recovery period there were hardly any differences between groups in physiological variables, blood flow and distribution of cardiac output to the organs studied (Table 1-3). Variable differences could only be observed in blood flow and distribution of combined cardiac output to the lower body, lung, cerebellum, gastrointestinal tract, portal vein, skeletal muscle and body skin. This was also true for the late recovery period (Tables 2,3).

\section{Pharmacokinetic studies}

Plasma concentrations of flunarizine increased after bolus injection to $121 \pm 5 \mu \mathrm{g} / \mathrm{L}$ serum at $2.5 \mathrm{~min}$ followed by a exponential decline to $22 \pm 1,3 \mu \mathrm{g} / \mathrm{L}$ over the next $2 \mathrm{~h}$ (Fig. 1). There was an accumulation of flunarizine in the various regions of the brain up to levels of $800 \mathrm{ng} / \mathrm{g}$ tissue (Fig. 2).

\section{DISCUSSION}

The central finding of the present study is that short term circulatory responses to acute asphyxia are not impaired by low dose flunarizine in fetal sheep near term. Before asphyxia distribution of combined ventricular output, physiological variables as well as concentrations of catecholamines in fetuses from the control group were in the normal range for chronically prepared fetal sheep near term. During acute asphyxia there was a redistribution of cardiac output towards the central organs accompanied by a pronounced bradycardia and a progressive increase in arterial blood pressure. 


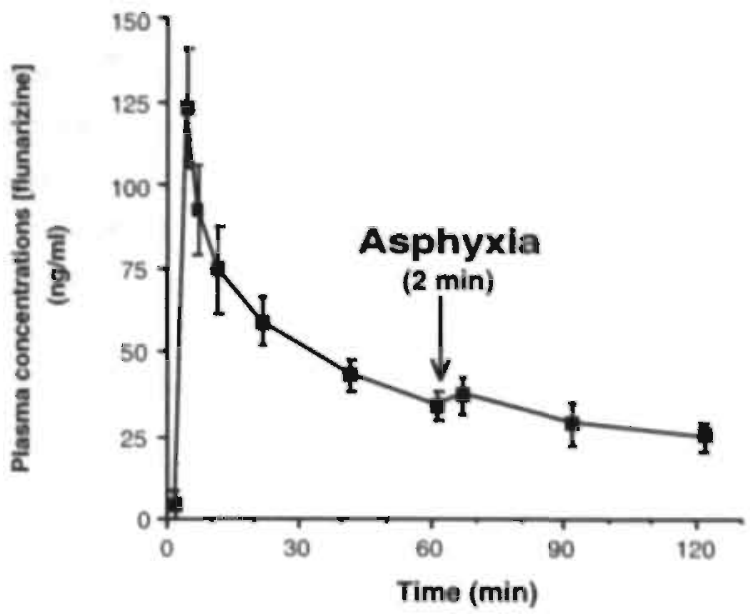

Figure I. Plasma concentrations of flunarizine $(\mathrm{ng} / \mathrm{ml})$ before, during and after arrest of uterine blood flow for 2 min. Fetuses $(\mathrm{n}=9$ ) received flunarizine ( $1 \mathrm{mg} / \mathrm{kg}$ estimated fetal weight) intravenously $60 \mathrm{~min}$ before acutẹ asphyxia.

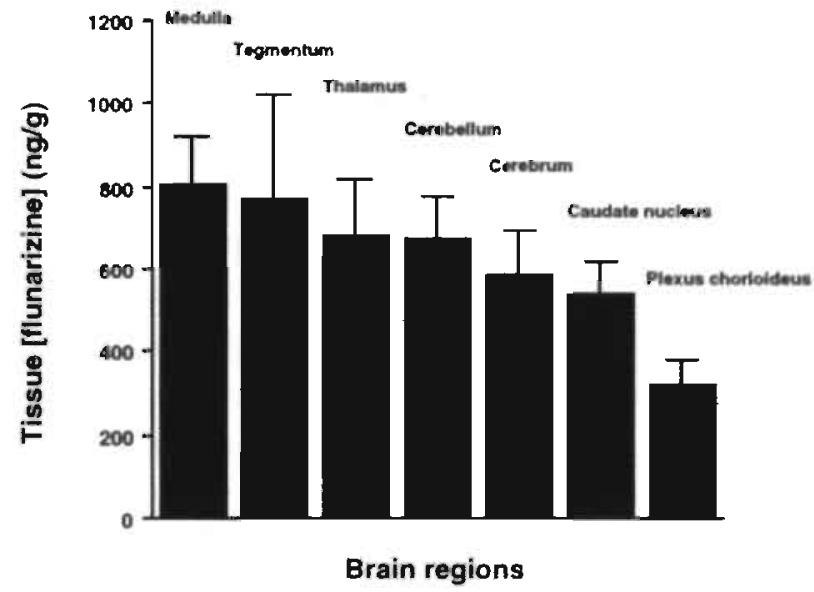

Figuirt 2. Accumulation of flunarizine: - administered $60 \mathrm{~min}$ before arrest of uterine blood flow for 2 min in various brain regions of the fetal sheep 120 min after acute asphyxia (columns are means \pm SEM; $n=7$ ). 


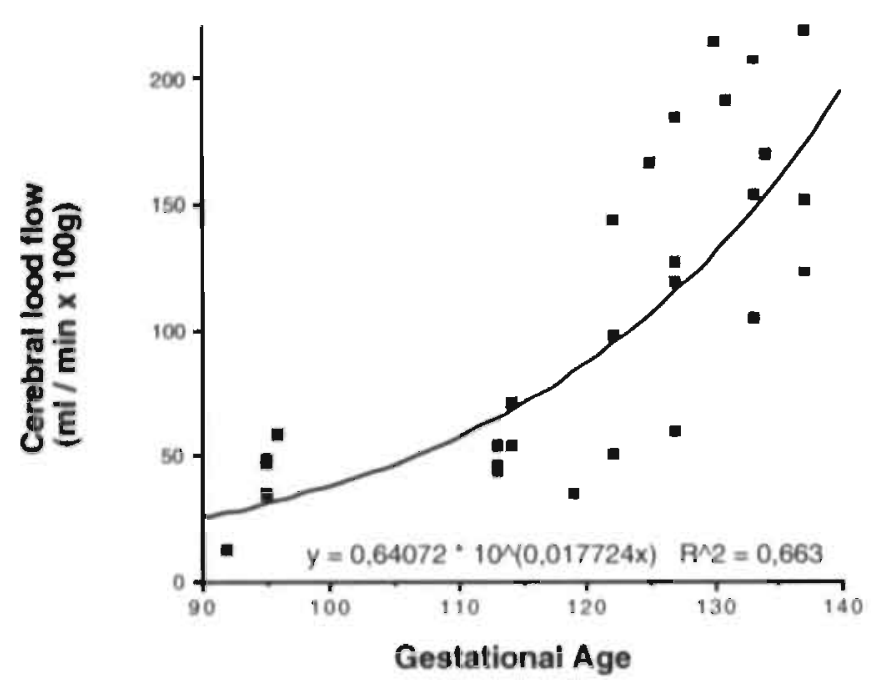

Figure 3. Relation between gestational age and cerebral blood flow in fetal sheep ( $n=28)$.

After asplyxia circulatory centralization did not resolve quite as rapidly as it developed, but was almost completely recovered at $30 \mathrm{~min}$ after the insult. There were almost no differences between groups in the time course of physiological and cardiovascular variables measured before, during and after acute intrauterine asphyxia. Furthermore, it should be emphasized that in both the treated and untreated fetuses cerebral blood flow did not increase during asphyxia inspite of an increase in arterial blood pressure, suggesting that during acute asphyxia cerebral autoregulation was maintained and not affected by low dose flunarizine. It was not the aim of the present study to examine the effects of flunarizine on neuronal survival in fetal sheep after intrauterine asphyxia, since it is well known that more severe hypoxic-ischemic insults are necessary to induce neuronal necrosis (Berger et al., 1998). In fact we were able to show in a previous paper that cerebral oxygen delivery below $3 \mathrm{ml} \mathrm{O}_{2} / 100 \mathrm{~g} / \mathrm{min}$ has to be maintained for $30 \mathrm{~min}$ to achieve a rate of neuronal cell damage up to $50 \%$ in parasagittal regions (Berger et al., 1996). However, before flunarizine may be considered to be tested in a clinical trial in a first approach possible detrimental side-effects on cardiovascular responses to acute asphyxial episodes must be excluded. Therefore, in this study we only looked at the effects of 2 min asphyxia on circulatory centralization. Further studies should address possible 
adverse effects of flunarizine on cardiovascular function during and after prolonged asphyxia.

In the present study there was a tendency to higher plasma catecholamine concentrations during asphyxia in the treated group of animal that does not seem to have any impact on fetal circulatory centralization. However, one might speculate that a vasoconstriction caused by an increased catecholamine release in the treated group during asphyxia could have been masked by a flunarizine induced vasodilatation. As known from studies in adult animals dopamine initially causes a vasoconstriction in the renal circulation induced by an alpha-adrenergic mechanism and later on a sustained vasodilatation mediated by specific dopamine receptors. Similar responses have been reported from the cerebral circulation (for review see Edvinsson and MacKenzie, 1977). Hence, it cannot be fully excluded whether a vasodilatation caused by flunarizine may have been antagonized a vasoconstriction induced by increased dopamine release in the treated group. However, at present there are no data available to clarify whether the observed differences in dopamine release between control and study group are of biological relevance.

Before asphyxia cerebral blood flow in treated animals was significantly lower than in the control group. After detailed analysis this could be largely attributed to a slight difference in the gestational age between fetuses from control and study group (133 $\pm 2 \mathrm{~d}$ vs. $129 \pm 1 \mathrm{~d}$ ). Figure 3 shows cerebral blood flow of 28 fetal sheep of different gestational age that have been operated at our laboratory during the same period in time as the animals from the present study. Indeed, there is a considerable increase in cerebral blood flow around $130 \mathrm{~d}$ of gestation that might explain the differences measured between control and study group. Irrespective of gestational age as a determinant of cerebral blood flow an influence of low dose flunarizine on cerebral circulation under control conditions has been excluded by two other studies in fetal sheep (de. Haan et al., 1993; Berger et al., 1998). In the present study tissue levels, of flunarizine determined in different parts of the brain were lower than those reported previously in adults after applying identical concentrations of flunarizine (Tegtmeier et al., 1987). However, in fetal animals the loss of the drug via diffusion across the placental barrier into the maternal compartment has to be taken into account. Nevertheless the tissue concentrations reached in our study were well within the neuroprotective therapeutic range (Todd et al., 1989).

From the present study we conclude that low dose flunarizine does not significantly affeci short term circulatory responses to acute asphyxia in sheep near term. Since low dose flunarizine protects the fetal brain from ischemic injury in sheep, its clinical use should be 
reconsidered, particularly in fetuses that are at risk of hypoxic-ischemic encephalopathy (Berger et al., 1998).

\section{ACKNOWLEDGEMENTS}

The excellent technical assistance of Harald Klossek, Otmar Adam, Dorothea Ehler and Monika Nickel is gratefully acknowledged. This work was supported by Deutsche Forschungsgemeinschaft and by Janssen Pharmaceutica (Beerse, Belgium).

\section{REFERENCES}

1. Berger R, Lehmann T, Karcher J, Schachenmayr W, Jensen A 1996 Relation between cerebrail oxygen delivery and neuronal cell damage in fetal sheep near term. Reprod Fertil Dev 8:317-321

2. Berger R, Lehmann T, Karcher J. Garnier Y, Jensen A 1998 Low dose flunarizine protects the fetal brain from ischemic injury in sheep. Pediatr Res, 44:277-282.

3. Chumas PD, Del Bigio MR, Drake JM, Tuor UI 1993 A comparison of the protective effect of dexamethasone to other potential prophylactic agents in a neonatal rat model of cerebral hypoxia-ischemia. J Neurosurg 79:414-420

4. de Haan HH, Van Reempts JLH, Borgers M, de Haan J, Vles JSH, Hasaart THM 1993 Possible neuroprotective properties of flunarizine infused after asphyxia in fetal lambs are not explained by effects on cerebral blood flow or systemic blood pressure. Pediatr Res 34:379.384

5. Edmonds HL Jr, Wauquier A, Melis W, van den Broeck WAE, van Loon J, Janssen PAJ 1985 Improved short-term neurological recovery with flunarizine in a canine model of cardiac arrest. Am J Emerg Med 3:150-155

6. Edvinsson L and MacKenzie ET 1977 Amine Mechanisms in the Cerebral Circulation. Pharmacol Rev 28: 275-348

7. Gunn AJ, Williams CE, Bennet L, Cook CJ, Gluckman PD 1988 Perinatal cerebral asphyxia: pharmacological intervention. Fetal Ther 3:98-107

8. Gunn AJ, Mydlar T, Bennet L, Faull RLM, Gorter S, Cook C, Johnston BM. Gluckman PD 1989 The neuroprotective actions of a calcium channel antagonist, flunarizine, in the infant rat. Pediatr Res 25:573-576

9. Gunn AJ. Williams CE, Mallard EC, Tan WKM, Gluckman PD 1994 Flunarizine, a calcium channel antagonist, is partially prophylactically neuroprotective in hypoxicischemic encephalopathy in the fetal sheep. Pediatr Res 35:657-663

10. Heymann MA, Payne BD, Hoffman JIE, Rudolph AM 1977 Blood flow measurements with radionuclide-labeled particles. Prog Cardiovasc Dis 20:55-79 
11. Jensen A, Berger R 1991 Fetal circulatory responses to oxygen lack. J Dev Physiol 16:181-207.

12. Jelinek J, Jensen A 1991 Catecholamine concentrations in plasma and organs of the fetal guinea pig during normoxaemia, hypoxaemia and asphyxia. J Dev Physiol $15: 145-152$.

13. Jensen A, Hohmann M, Künzel W 1987 Dynamic changes in organ blood flow and oxygen consumption during acute asphyxia in fetal sheep. J Dev Physiol 9:543-559

14. Jensen A, Roman Ch, Rudolph AM 1991 Effects of reducing uterine blood flow on foetal blood flow distribution and oxygen delivery. J Dev Physiol 15:309-323.

15. Krieglstein J 1988 Pharmacology of Cerebral Ischemia. Wissenschaftliche Verlagsgesellschaft, Stuttgart.

16. Krieglstein J, Oberpichler-Schwenk H 1994 Pharmacology of Cerebral Ischemia. medpharm Scientific Publishers, Stuttgart.

17. Marranes R, Edmonds HL Jr, Wauquier A, Melis W, van Loon J 1986 Measurement of ischemic changes in cerebral blood flow by the hydrogen clearance technique and brain cortical temperature. Influence of flunarizine. Arch Int Pharmacodyn 281:209. 229

18. Newberg LA, Steen PA, Milde JH, Michenfelder ID 1984 Failure of flunarizine to improve cerebral blood flow or neurologic recovery in a canine model of complete cerebral ischemia. Stroke 15:666-671.

19. Rudolph AM, Heymann MA 1967 Circulation of the fetus in utero: Methods for studying distribution of blood flow, cardiac output and organ blood flow. Circ Res 21:163-184

20. Silverstein FS, Buchanan K, Hudson C, Johnston MV 1986 Flunarizine limits hypoxia-ischemia induced morphologic injury in immature rat brain. Stroke 17:477482

21. Tegtmeier F, Dengler K, Zacharias E, Eichhorn R, Höller M 1987 Brain concentrations and effect of cerebroprotective drugs - investigations with flunarizine and R 56865. Preclinical Research Report, Janssen Research Foundation.

22. Todd PA, Benfield P 1989 Flunarizine. A reappraisal of its pharmacological properties and therapeutic use in neurological disorders. Drugs 38:481-499

23. Van Reempts J, Borgers M, Van Dael L, van Eyndhoven J, Van de Ven M 1993 Protection with flunarizine against hypoxic-ischemic damage of the rat cerebral cortex. A quartitative morphologic assessment. Arch Int Pharmacodyn Ther 232:7688

24. Volpe JJ 1995 Neurology of the Newborn. Saunders, Philadelphia. 
Chapter 5

\section{LOW DOSE FLUNARIZINE PROTECTS THE FETAL BRAIN FROM ISCHEMIC INJURY IN SHEEP}

Berger R, Lehmann T, Karcher J, Garnier Y, Jensen A Pediatric Research, 1998;44:1-6 


\section{ABSTRACT}

Flunarizine, a calcium channel blocker, reduced cerebral damage caused by hypoxicischemic insults in neonatal rats and in fetal sheep near term. However, the high dose regimen used in these studies produced cardiovascular side-effects that might have counteracted the neuroprotective properties of flunarizine. Therefore, the neuroprotective effect was tested in a low dose protocoll ( $1 \mathrm{mg} / \mathrm{kg}$ estimated BW). Twelve fetal sheep near term were instrumented chronically. Six fetuses were pretreated with $1 \mathrm{mg}$ flunarizine per $\mathrm{kg}$ estimated body weight $1 \mathrm{~h}$ before ischemia, while the remainder $(n=6)$ received solvent. Cerebral ischemia was induced by occluding both carotid arteries for $30 \mathrm{~min}$. To exclude the possibility that the neuroprotective effects of flunarizine were caused by cerebrovascular alterations we measured cerebral blood flow by injecting radio-labelled microspheres before $(-1 \mathrm{~h})$, during $(+3 \mathrm{~min}$ and $+27 \mathrm{~min})$ and after $(+40 \mathrm{~min},+3 \mathrm{~h}$ and $+72 \mathrm{~h})$ cerebral ischemia. At the end of the experiment $(+72 \mathrm{~h})$ the ewe was given a lethal dose of sodium pentobarbitone and saturated potassium chloride i.v., and the fetal brain was perfused with formalin. Neuronal cell damage was assessed in various brain structures by light microscopy after cresyl violet/fuchsin staining using a scoring system (0-5\% damage (1), 5-50\% damage (2), 50-95\% damage (3), 95-99\% damage (4), $100 \%$ damage (5)). In ten other fetal sheep effects of low dose flunarizine on circulatory centralization caused by acute asphyxia could be excluded. In the treated group neuronal cell damage was reduced significantly in many cerebral areas to varying degrees (range - control group: 1.03-2.14 vs. range - treated group: $1.00-1.13 ; \mathrm{P}<0.05$ to $\mathrm{P}<0.001$ ). There were only minor differences in blood flow to the various brain structures between groups. We conclude that pretreatment with low dose flunarizine protects the brain of fetal sheep near term from ischemic injury. This neuroprotective effect is not mediated by changes in cerebral blood flow. We further conclude that low dose flunarizine may be clinically useful as a treatment providing fetal neuroprotection, particularly since the fetal cardiovascular side effects are minimal. 


\section{INTRODUCTION}

Hypoxic-ischemic cerebral damage is an important contributor to perinatal mortality and morbidity including long-term neurological sequelae in term and preterm fetuses (1). Over the last decade many therapeutic strategies have been developed to reduce neuronal damage caused by ischemic insults in neonatal and adult animals. These have included application of calcium antagonists, glutamate antagonists, oxygen radical scavengers, and nitric oxide synthetase blockers (for review, see Krieglstein et al. (2)). Perinatal use of neuroprotective strategies may be particularly successful, since pretreatment of individuals at risk of hypoxic-ischemic encephalopathy might be possible. There is evidence that flunarizine, a class IV calcium channel blocker, is more effective as a neuroprotective drug in pretreatment (3-7) than in post-treatment protocols (8). However, the high dose regimen ( $30-45 \mathrm{mg} / \mathrm{kg}$ body weight) used in those studies had severe cardiovascular side-effects (7.9). The present study was therefore designed to test whether ischemic insults in fetal sheep near term could be also reduced by a low dose flunarizine protocol. To account for drug-related changes in cerebral blood flow that might affect neuronal cell damage we measured cerebral blood flow by the microsphere method.

\section{METHODS}

The experimental model and measurement of the associated variables have been described in detail previously $(10)$.

\section{Animal preparation}

Twelve fetal sheep were chronically prepared at a gestational age of $\mathbf{1 2 5}$ days iterm is at 147 days). All ewes were anesthetized by subarachnoid injection of $8 \mathrm{ml}$ of $0.75 \%$ (w/v) bupivacaine at the lower spine, and were operated under sterile conditions. Polyvinyl catheters were placed in a maternal iliac artery and vein through tibial vessels. The ewe's abdominal wall was opened in the midline and through a small uterine incision, the fetal hindlimbs were exposed. Using local anesthesia with $1.0 \%(w / v)$ prilocaine $\mathrm{HCl}$, polyvinyl catheters were inserted via the pedal vein of each hindlimb into the inferior vena cava. The uterine incision was closed and a second uterine incision was made over the fetal snout. Head and neck of the fetus were exteriorized. To prevent the fetus from breathing, its head was covered by a water-filled rubber glove. Catheters were inserted into both fetal brachial arteries. Furthermore, both fetal common carotid arteries were prepared. Cerebral ischemia was induced by occluding the carotid arteries on both sides simultaneously below the thyroid and above the lingual artery for $30 \mathrm{~min}$ as described recently (10). Thus, blood flow to the cerebrum via anastomoses between the carotid and vertebral arteries was 
arrested. After cerebral ischemia a catheter was placed into the amniotic cavity, and the second intrauterine incision was closed. All catheters were filled with heparin (1000 IU/mI), plugged, and passed subcutaneously to the ewe's flank, where they were exteriorized and protected by a pouch sewn to the skin. On the day of surgery and each day thereafter, the ewe received 2 million units of penicillin G (Grünenthal, Germany) and 80 mg of gentamycin sulfate (Merck, Germany), half intravenously and half into the amniotic cavity.

\section{Experimental Protocol}

About $30 \mathrm{~min}$ before preparation of the carotid arteries 6 fetuses received a bolus of flunarizine ( $1 \mathrm{mg} / \mathrm{kg}$ estimated body weight) intravenously, while an equal volume of the solvent was administered to the remaining fetuses. The drugs were donated by Janssen Pharmaceutica, Beerse, Belgium. The dosage applied was within the therapeutic range (11). The experiments were done in a randomized fashion. The operators were not blind to the nature of injection. Sixty min after flunarizine injection cerebral ischemia was started. To determine the time course of changes in fetal cerebral blood flow before (-15 min), during ( $+3 \mathrm{~min}$ and $+27 \mathrm{~min})$, and after $(+10 \mathrm{~min},+3 \mathrm{~h},+72 \mathrm{~h}) 30 \mathrm{~min}$ of cerebral ischemia, six batches of microspheres labelled with different isotopes $\left({ }^{1+1} \mathrm{Ce},{ }^{114} \mathrm{In},{ }^{113} \mathrm{Sn}\right.$, ${ }^{103} \mathrm{Ru},{ }^{95} \mathrm{Nb}$ and ${ }^{46} \mathrm{Sc}, 16 \mu \mathrm{m}$ diam., New England Nuclear) were injected into the inferior vena cava, while reference samples from the brachial artery were withdrawn at a rate of 2.5 $\mathrm{ml} / \mathrm{min}$ for $90 \mathrm{~s}$ (12). During and shortly after cerebral ischemia, fetal heart rate, and ascending aortic and intrauterine pressure were recorded simultaneously. After having injected the fourth batch of microspheres $(+10 \mathrm{~min})$ all catheters were closed and secured as described above, the abdominal wall was closed and the ewe was brought back to the metabolic cage, where the fifth injection $(+3 \mathrm{~h})$ was given. For organizational reasons there were no pressure measurements at this point in time. Before each injection blood samples were obtained from the brachial artery to measure blood gases, oxygen saturation of. hemoglobin, and acid-base balance. At the end of the experiment $(+72 \mathrm{~h})$ the ewe was given a lethal dose of sodium pentobarbitone and saturated potassium chloride intravenously, and the fetus was perfused with $300 \mathrm{ml}$ of formalin $(15 \%$, w/v, saline).

The experimental protocols were approved by the appropriate institutional review committee and met the guidelines of the governmental agency responsible. 


\section{Measurements}

Ascending aortic and intrauterine pressure, and fetal heart rate were recorded on a polygraph (Hellige, Germany). Blood gases and pH were measured in an automatic blood gas analyzer (278 Blood Gas System, Ciba Corning, Frankfurt, Germany), and base excess was calculated. Hemoglobin concentration and oxygen saturation of hemoglobin were measured photometrically (OSM 2 Hemoximeter, Radiometer, Copenhagen, Denmark) in duplicate. Fetal cerebral blood flow and the extent of neuronal cell damage were assessed in identical brain specimens. To determine fetal cerebral blood flow using the microsphere method, the fetal brain was removed and fixed in formalin for at least seven days. Afterwards the cerebrum was separated from the basal ganglia and divided in four frontal sections (rostral, pericentral, postcentral, occipital) with a thickness of about $1.5 \mathrm{~cm}$. The right and left parts of these four sections were further subdivided into four equally sized segments (sagittal 1 and 2, lateral 1 and 2) each weighing 1-2 g. In addition to these 32 cerebral specimens, the caudate nucleus, thalamus, hippocampus, tegmentum-colliculipons, cerebellum, and medulla oblongata were separated. These brain structures were placed into vials, which were filled to the same height to reduce variations in geometry during gamma counting. The solid-state semi-conductor germanium $(\mathrm{Ge})$ gamma counter used had a high energy resolution of about $3 \mathrm{keV}$ and was connected to a multichannel (2048) pulse height analyzer (ND 62, Nuclear Data Inc., Illinois, USA). The results were normalized with respect to time and sample weight.

After cerebral blood flow analysis the specimens of the fetal brain were removed from the counting vials and embedded in paraffin. Coronal subserial sections of $10 \mu \mathrm{m}$ were obtained and then stained with cresyl violet/fuchsin. Every 40 th section was mounted to evaluate the extent of neuronal cell damage. Neuronal cell damage was assessed at a magnification of $250 \mathrm{x}$. Neurons with ischemic cell damage were identified according to the criteria of Brown and Brierley (13). Neuronal cell damage in each microscopical visual field was quantified as follows: 0 - $5 \%$ damage (score 1), 5 - $50 \%$ damage (score 2), 50 $95 \%$ dannage (score 3 ), 95 - $99 \%$ damage (score 4 ), $100 \%$ damage (score 5 ).

\section{Calculations}

Fetal cerebral blood flow was calculated from counts of the injected nuclide recovered in the fetal cerebrum and the appropriate reference sample, and from the withdrawal rate of the reference sample (12). The histological score of each cerebral specimen was calculated by averaging the scores of all visual fields analysed from 3 sections of that specimen. The number of scored visual fields per specimen ranged between 400 and 500 each. The scores from corresponding specimens from the right and left hemisphere were averaged. 


\section{Effects of low-dose flunarizine on fetal circulatory centralization}

Since flunarizine, a class IV calcium antagonist, is a potent vasodilator, the neuroprotective effects of this drug may be counteracted by its cardiovascular side-effects. To clarify this point we subjected 10 chronically instrumented sheep fetuses (gestational age: $132 \pm 1$ days) to acute intrauterine asphyxia (14). Fetuses from the study group received flunarizine (1 $\mathrm{mg} / \mathrm{kg}$ estimated body weight) intravenously $60 \mathrm{~min}$ before asphyxia, while solvent was administered to the fetuses of the control group. Organ blood flows, physiological variables and plasma concentrations of catecholamines were measured before, during and after arrest of uterine blood flow for $2 \mathrm{~min}$, i.e., at $0,1,2,3,4$, and $30 \mathrm{~min}$. Before asphyxia, the distribution of combined ventricular output, physiological variables and concentrations of catecholamines in fetuses from the control group were within the normal range for chronically prepared fetal sheep near term. During acute asphyxia there was a redistribution of cardiac output towards the central organs (Fig. 1) accompanied by a pronounced bradycardia and a progressive increase in arterial blood pressure. Fetuses of the study group had higher plasma catecholamine levels than the control group. After asphyxia, circulatory centralization did not resolve quite as rapidly as it had developed, but was almost completely recovered at $30 \mathrm{~min}$ after the insult. There were hardly any differences between treated animals and controls in the time course of physiological and cardiovascular variables measured before, during and after acute intrauterine asphyxia (Fig. 1). Low dose flunarizine does not, therefore, seem to affect fetal circulatory responses to acute asphyxia in sheep near term.

\section{Statistics}

Values are given as means \pm SD. Statistical differences in physiological variables, cerebral blood flow, and neuronal cell damage within and between groups were evaluated using a 2-way analysis of variance followed by Games-Howell post-hoc test. Owing to the problem of multiple test performing the resulting $\mathbf{P}$-values have to be regarded as descriptive. 

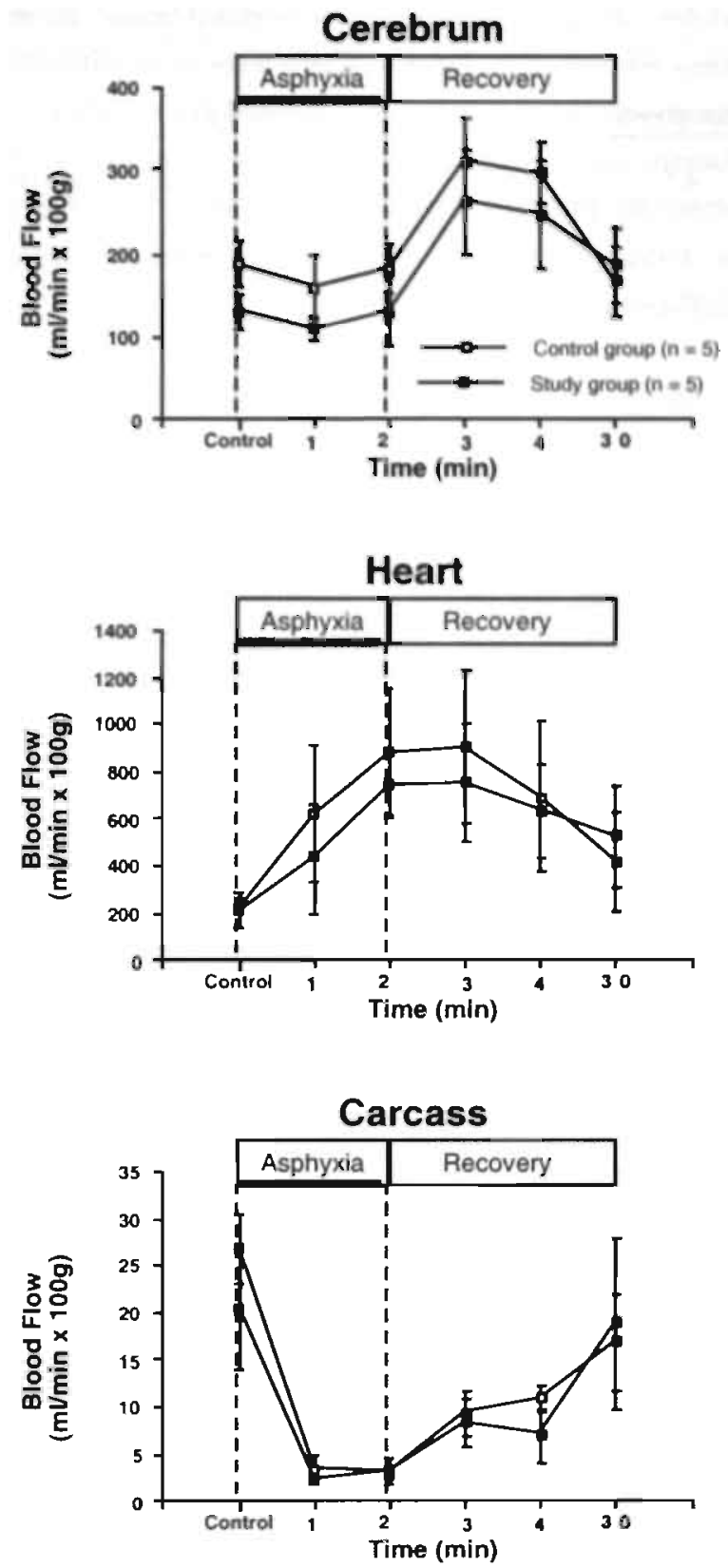

Figure 1. Blood flow to the cerebrum, heart, and carcass $(\mathrm{mL} / \mathrm{min} \times 100 \mathrm{~g})$ in fetal sheep near term before, during, and after arrest of uterine blood flow for $2 \mathrm{~min}$, i.e. at $0,1,2,3,4$, and $30 \mathrm{~min}$. Fetuses from the study group (filled squares; $n=5$ ) received flunarizine ( $\mathrm{mg} / \mathrm{kg}$ estimated fetal BW) i.v. $60 \mathrm{~min}$ before asphyxia, whereas solvent was administered to the fetuses of the control group (open squares; $n=5$ ). 


\section{RESULTS}

The physiological variables of the conirol and the study group before, during and after 30 mis of cerehral ischemia are shown in Table 1 . There were no significant differences in these variahles between groups. Al conirol the arterial blood pH, the plasma concentrations of both glucose and lactate, and the mean arterial blood pressure were slightly above the normal range for chronically prepared fetal sheep (15). However, after ischemia these variables normalized Furthermore there were no: time-dependent differences in the remaining physiological variables: (Table i)

No differences in blood flow to the 30 specimens from the fetal cerebrum could be gberved between treatediandicentrol groups, Table 2 shows the mean blood flows to these specimens, During ischemia cerebal blood flow was reduced to less than $20 \mathrm{mbl} / 00 \mathrm{~g} / \mathrm{min}$. In. the immediate recovery period there was hyperperfusion ( +10 min) followed by a

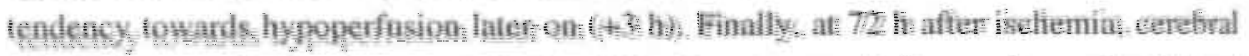
blood!low was higher than control rates, This time course of elianges in ceretral blood flow could be observed in almost ail brain structures.

In Table 3 the histological scores for the 16 corresponding areas from both sides of the cerebrum are shown. The most pronounced neuronal cell damage was detected in the parasagittal regions, whereas in the more lateral part of the cortex only minor neuronal damage occured. Ischemic injury could be observed in 172 out of 192 cerebral specimens of the control group, but in only 69 of 192 study group samples. Damage to deeper brain structures could be detected only in a few areas, mainly in the hippocampus and cerebellum (Table 4). Neuronal cell damage was found more often in controls than in treated animals in the hippocampus (10/12 vs. $4 / 12)$ and cerebellum (6/12 vs. 1/12). Interestingly, there was a tremendous reduction in neuronal cell damage in aimost all parts of the cerebrum after pretreatment with flunarizine (Table 3 ). 
Table 1. Physiological Variables Before, During and After 30 Minutes of Cerebral Ischemia with (F) and without (C) Pretreatment with Flunarizine

\begin{tabular}{|c|c|c|c|c|c|c|}
\hline & \multirow[b]{2}{*}{ Control } & \multicolumn{2}{|c|}{ Ischemia } & \multicolumn{3}{|c|}{ Recovery } \\
\hline & & $3 \mathrm{~min}$ & $27 \mathrm{~min}$ & $10 \mathrm{~min}$ & $3 \mathrm{~h}$ & $72 \mathrm{~h}$ \\
\hline \multicolumn{7}{|l|}{$\mathrm{pH}$} \\
\hline $\mathrm{C}$ & $7.34 \pm 0.03$ & $7.35 \pm 0.03$ & $7.34 \pm 0.05$ & $7.33 \pm 0.05$ & $7.36 \pm 0.02$ & $7.39 \pm 0.02$ \\
\hline $\mathrm{F}$ & $7.29 \pm 0.05$ & $7.30 \pm 0.04$ & $7.32 \pm 0.04$ & $7.28 \pm 0.06$ & $7.30 \pm 0.06$ & $7.38 \pm 0.02 c$ \\
\hline \multicolumn{7}{|c|}{$\mathrm{pO}_{2}(\mathrm{mmHg})$} \\
\hline$c^{2}$ & $21.9 \pm 2.7$ & $21.3 \pm 4.4$ & $22.0 \pm 3.3$ & $21.6 \pm 2.8$ & $25.1 \pm 1.7$ & $22.8 \pm 2.7$ \\
\hline $\mathbf{F}$ & $21.6 \pm 2.9$ & $21.4 \pm 3.7$ & $20.9 \pm 4.5$ & $19.5 \pm 2.2$ & $19.9 \pm 2.6$ & $21.1 \pm 3.4$ \\
\hline \multicolumn{7}{|c|}{$\mathrm{pCO}_{2}(\mathrm{mmHg})$} \\
\hline C & $45.7 \pm 3.3$ & $44.4 \pm 5.8$ & $44.1 \pm 4.0$ & $43.5 \pm 4.1$ & $46.7 \pm 2.1$ & $46.8 \pm 2.7$ \\
\hline $\mathbf{F}$ & $48.5 \pm 5.2$ & $45.6 \pm 4.1$ & $45.7 \pm 3.9$ & $46.5 \pm 3.2$ & $48.0 \pm 2.4$ & $46.0 \pm 3.0$ \\
\hline \multicolumn{7}{|c|}{ Oxygen Saturation (\%) } \\
\hline C & $67.4 \pm 9.8$ & $65.2 \pm 15.6$ & $67.6 \pm 12.5$ & $65.3 \pm 10.2$ & $77.2 \pm 4.3$ & $71.7 \pm 10.1$ \\
\hline $\mathrm{F}$ & $60.0 \pm 9.8$ & $58.1 \pm 10.7$ & $59.3 \pm 12.8$ & $54.3 \pm 9.4$ & $56.8 \pm 10.9$ & $66.0 \pm 10.1$ \\
\hline \multicolumn{7}{|c|}{ Glucose ( $\mathrm{mg} / \mathrm{ml}$ ) } \\
\hline $\mathrm{C}$ & $57.8 \pm 19.2$ & $59.0 \pm 14.6$ & $61.7 \pm: 17.7$ & $57.7 \pm 20.7$ & $32.3 \pm 12.6 a$ & $17.8 \pm 4.3 \mathrm{c}$ \\
\hline F & $70.2: \pm 18.0$ & $63.8 \pm 18.4$ & $67.3 \pm 21.5$ & $65.3 \pm 25.7$ & $41.5 \pm 19.1 \mathrm{a}$ & $19.5 \pm 9.4 \mathrm{c}$ \\
\hline \multicolumn{7}{|c|}{ Lactate (mmol/) } \\
\hline $\mathrm{C}$ & $3.83 \pm 0.82$ & $3.75 \pm 0.98$ & $4.65 \pm 1.77$ & $5.15 \pm 1.52$ & $3.73 \pm 0.60$ & $1.30 \pm 0.18 \mathrm{a}$ \\
\hline $\mathrm{F}$ & $3.65 \pm 0.93$ & $3.50 \pm 1.16$ & $3.87 \pm 1.33$ & $4.73 \pm 2.04$ & $4.68 \pm 2.36$ & $1.40 \pm 0.31 \mathrm{a}$ \\
\hline \multicolumn{7}{|c|}{ Fetal Heart Rate $\left(\mathrm{min}^{-1}\right)$} \\
\hline $\mathrm{C}$ & $168 \pm 15$ & $191 \pm 19$ & $197 \pm 31$ & $199 \pm 35$ & n.m. & $161 \pm 10$ \\
\hline F & $147 \pm 29$ & $171 \pm 56$ & $195 \pm 55 \mathrm{a}$ & $170 \pm 33$ & n.m. & $162 \pm 16$ \\
\hline \multicolumn{7}{|c|}{ Mean Arterial Pressure (mmHg) } \\
\hline C & $51 \pm \llbracket 1$ & $64 \pm 10$ a & $58 \pm 13$ & $53 \pm 9$ & n.m. & $41 \pm 3$ \\
\hline $\mathrm{F}$ & $54 \pm 7$ & $68 \pm 11$ a & $67 \pm 12$ a & $50 \pm 14$ & n.m. & $42 \pm 10$ \\
\hline
\end{tabular}

Values are given as means \pm SD. Significant differences within groups are indicated by $a: p<0.05: b: p<0.01$ : $: p<0.001$ and between groups by $d: p<0.05 ; c: p<0.01 ; f: p<0.001$. n.m. $=$ not measured 
Table 2. Regional Cerebral Blood Flow (mL/100g tissue/min) Before, During and After 30 Minutes of Cerebral Ischemia with (F) and without (C) Pretreatment with Flunarizine

\begin{tabular}{ccccccc} 
& \multicolumn{2}{c}{ Ischemia } & & \multicolumn{3}{c}{ Recovery } \\
\cline { 2 - 3 } \cline { 5 - 7 } Control & $3 \mathrm{~min}$ & $27 \mathrm{~min}$ & & $10 \mathrm{~min}$ & $3 \mathrm{~h}$ & $\mathbf{7 2 ~ h}$ \\
\hline
\end{tabular}

\section{Cerebrum}

$\begin{array}{ccccccc}\text { C } & 100.6 \pm 27.1 & 15.5 \pm 8.3 \mathrm{c} & 19.6 \pm 9.1 \mathrm{c} & 206.5 \pm 65.7 \mathrm{c} & 68.2 \pm 16.7 & 160.9 \pm 22.6 \mathrm{~b} \\ \mathrm{~F} & 88.5 \pm 19.0 & 11.0 \pm 2.1 \mathrm{c} & 17.0 \pm 7.2 \mathrm{c} & 168.0 \pm 50.8 \mathrm{c} & 84.5 \pm 20.9 & 147.5 \pm 64.5 \mathrm{~b}\end{array}$

\section{Caudate nucleus}

$\begin{array}{lllllll}\text { C } & 125.8 \pm 34.2 & 34.4 \pm 29.7 \mathrm{~b} & 35.5 \pm 15.1 \mathrm{~b} & 257.0 \pm 94.7 \mathrm{c} & 99.1 \pm 32.1 & 223.9 \pm 66.3 \mathrm{~b} \\ \mathrm{~F} & 124.2 \pm 33.1 & 24.9 \pm 17.2 \mathrm{~b} & 37.4 \pm 16.6 \mathrm{a} & 187.2 \pm 67.7 \mathrm{~d} & 107.9 \pm 36.6 & 195.7 \pm 85.8 \mathrm{a}\end{array}$

\section{Thalamus}
C $\quad 157.4 \pm 51.0$
$27.7 \pm 17.0 \mathrm{~b}$
$46.1 \pm 18.8$ b $\quad 432.0 \pm 185.8$ c $\quad 113.4 \pm 2.5 .4$
$250.5 \pm 35.6$ a
F $\quad 164.9 \pm 40.3$
$20.6 \pm 11.2 \mathrm{c}$
$34.6 \pm 15.9$ b $299.0 \pm 97.7$ b.e $\quad 158.5 \pm 50.8$
$216.2 \pm 94.2$

\section{Hippocampus}
C $\quad 90.5 \pm 19.7$
$18.9 \pm 14.8 b$
$31.6 \pm 16.3 \mathrm{~b}$
$219.5 \pm 85.6 \mathrm{c}$
$65.5 \pm 14.4$
$173.0 \pm 31.2 \mathrm{c}$
F $\quad 93.1 \pm 26.3$
$23.1 \pm 14.5 b$
$24.9 \pm 6.6 \mathrm{~b} \quad 177.3 \pm 39.6 \mathrm{c}$
$88.1 \pm 22.3$
$158.8 \pm 71.8 b$

\section{Colliculi, Tegmentum, Pons}

$\begin{array}{lllllll}\text { C } & 196.5 \pm 57.1 & 27.4 \pm 14.3 \mathrm{~b} & 48.8 \pm 18.1 \mathrm{~b} & 434.8 \pm 229.7 \mathrm{c} & 140.1 \pm 41.8 & 315.7 \pm 64.6 \mathrm{a} \\ \mathrm{F} & 196.0 \pm 51.6 & 16.3 \pm 8.8 \text { b } & 44.5 \pm 15.7 \mathrm{~b} & 327.5 \pm 171.7 \mathrm{a} & 198.7 \pm 43.5 & 256.8 \pm 104.7\end{array}$

\section{Cerebellum}

$\begin{array}{lllllll}\text { C } & 155.9 \pm 69.3 & 27.2 \pm 21.5 \text { b } & 45.0 \pm 20.8 \text { a } & 420.5 \pm 156.0 \text { c } & 163.9 \pm 74.1 & 273.2 \pm 87.2 \text { b }\end{array}$

F $\quad 152.0 \pm 29.3 \quad 28.0 \pm 20.3$ b $\quad 40.5 \pm 18.7$ a $298.3 \pm 83.0$ b.e $\quad 184.8 \pm 32.4251 .2 \pm 110.2$ a

\section{Medulla}

$\begin{array}{lllllll}\text { C } & 207.6 \pm 59.0 & 64.5 \pm 29.6 \mathrm{~b} & 64.2 \pm 32.1 \mathrm{~b} & 210.7 \pm 96.6 & 204.6 \pm 79.4 & 372.4 \pm 73.7 \mathrm{~b} \\ \text { F } & 198.6 \pm 67.8 & 54.0 \pm 19.2 \mathrm{~b} & 63.2 \pm 31.9 \mathrm{a} & 297.3 \pm 223.3 & 216.3 \pm 66.5 & 274.6 \pm 126.8\end{array}$

\begin{tabular}{|c|c|}
\hline & $54.0 \pm 19$ \\
\hline $198.6 \pm 67.8$ & \\
\hline
\end{tabular}

Values are given as means \pm SD. Significant differences within groups are indicated by

$\mathrm{a}: \mathrm{p}<0.05 ; \mathrm{b}: \mathrm{p}<0.01$; $: \mathrm{p}<0.001$ and between groups by $\mathrm{d}: \mathrm{p}<0.05 ; \mathrm{e}: \mathrm{p}<0.01$ : $\mathrm{f}: \mathrm{p}<0.001$. 
Table 3. Neuronal Cell Damage in the Cerebrum After 30 Min of Ischemia with (F) and without (C) Pretreatment with Flunarizine

\begin{tabular}{|c|c|c|c|c|}
\hline & & Segment & & \\
\hline & Parasag & ttal & Later & \\
\hline & $\mathbf{I}$ & 2 & 1 & 2 \\
\hline Ros & & & & \\
\hline C & $1.42 \pm 0.52$ & $1.26 \pm 0.26$ & $1.36 \pm 0.55$ & $1.48 \pm 0.78$ \\
\hline $\mathrm{F}$ & $1.03 \pm 0.05$ & $1.02+0.03$ & $1.05+0.11$ & $1.10 \pm 0.23$ \\
\hline & ntral & & & \\
\hline C & $2.11 \pm 0.84$ & $1.50 \pm 0.38$ & $1.48 \pm 0.70$ & $1.09 \pm 0.19$ \\
\hline $\mathrm{F}$ & $1.12 \pm 0.18$ & $1.06 \pm 0.12 *$ & $1.00+0.01+$ & $1.00+0.01$ \\
\hline Pos & ntral & & & \\
\hline $\mathrm{C}$ & $2.14 \pm 1.10$ & $1.90 \pm 0.96$ & $1.62 \pm 0.78$ & $1.03 \pm 0.04$ \\
\hline $\mathrm{F}$ & $1.11 \pm 0.22^{* * *}$ & $1.13 \pm 0.21^{* *}$ & $1.01 \pm 0.01 *$ & $1.01 \pm 0.02$ \\
\hline $\mathrm{Oec}$ & ital & & & \\
\hline C & $1.65 \pm 0.94$ & $1.77 \pm 1.02$ & $1.67 \pm 0.88$ & $1.53 \pm 0.82$ \\
\hline F & $1.00 \pm 0.00^{*}$ & $1.01 \pm 0.01 * *$ & $1.02 \pm 0.05^{*}$ & $1.01 \pm 0.02 \uparrow$ \\
\hline
\end{tabular}

Values are given as means \pm SD. Significant differences between groups are indicated

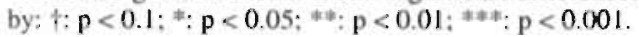

Table 4. Neuronal Celi Damage in various Areas of the Diencephalon, Mesencephalon and Brain Stem After 30 Min of Ischemia with $(\mathrm{F})$ and without $(\mathrm{C})$ Pretreatment with Flunarizine

\begin{tabular}{lll}
\hline Caudate nucleus & C & $1.02 \pm 0.05$ \\
Thalamus & F & $1.04 \pm 0.09$ \\
Hippocampus & C $1.00 \pm 0.00$ \\
Tegmentum, Colliculli, Pons & F $1.00 \pm 0.00$ \\
Cerebellum & C $1.54 \pm 0.65$ \\
& C $1.28 \pm 0.43$ \\
Medulla & F $1.01 \pm 0.00$ \\
& F $1.26 \pm 0.33$ \\
& C $1.00 \pm 0.03$ \\
& F $1.00 \pm 0.00$ \\
\hline
\end{tabular}




\section{DISCUSSION}

As shown in previous studies pretreatment of immature animals with flunarizine seems to reduce ischemic neuronal cell damage dramatically (3-7). In some of these studies neonatal rats were subjected to hypoxia after ligation of one carotid artery (3-6). Flunarizine was applied at a relatively high concentration $(30 \mathrm{mg} / \mathrm{kg} \mathrm{BW})$ before hypoxia. Ipsilateral infarction of the brain could be almost totally prevented in animals receiving such treatment (3-6). Similar results have been described by Gunn and co-workers using a fetal sheep model (7). However, the high dose regimens used by these authors had severe cardiovascular side-effects $(7,9)$. In the present study we were able to show that pretreatment of fetal sheep near term with low dose flunarizine significantly reduces cerebral damage after ischemia. Since we have also provided evidence that low dose flunarizine does not alter the response of the fetal cardiovascular system to intrauterine asphyxia, this therapeutic regimen appears to be safe and may qualify for clinical trials. Because the transport of flunarizine across the placental membrane barrier is very fast due to its lipophilic properties (11), direct application to the fetus by chordocentesis would not be necessary. Thus, women camying babies at risk of hypoxic-ischemic encephalopathy, i.e. IUGR or preterm fetuses, could be given low dose flunarizine intravenously before birth.

The observed neuroprotective effect of flunarizine in fetal sheep appears to be at variance with some studies in adult animals (16-19). These discrepancies may arise from differences in experimental design. The anticonvulsive properties of flunarizine should also be taken: into consideration here. Unlike adult studies, the fetuses in intrauterine experiments are subjected not only to the ischemic insult itself, but also to postischemic seizure activity (20,21). Flunarizine is in part an anticonvulsant (11). Therefore, in studies in which seizure activity is part of the experiment. the neuroprotective effects may be more pronounced. This may explain the overt differences between experiments in adult and fetal animals. An interesting finding of this study is that flunarizine increases plasma catecholamine levels during acute asphyxia. Since elevated catecholamine levels seem to reduce ischemic cerebral injury (22), this observation may reveal one of the mechanisms by which flunarizine protects the fetal brain from neuronal cell damage.

In the present study there was little or no damage to deeper brain structures. This may be related to minor degrees of the ischemic insult: neuroprotection could not be demonstrated. for example, in diencephalic and brain stem areas. The fact that deeper brain structures were not damaged by the ischemic model used here may constitute an important difference to the clinical situation, since basal ganglia seem to be selectively vulnerable in hypoxicischemic encephalopathy (1). However, to mimic a clinical situation asphyxia models are 
required, which have the disadvantage that the degree and distribution of neuronal injury varies immensely. Using such models it is, therefore, very difficult to test the neuroprotective properties of different drugs. Since this was the main aim of the present study, we chose to use the ischemic model described.

We observed a more pronounced neuronal cell damage in this study than in a previous one (10), a fact that might be related to differences in methods. We now used a double occlusion of the carotid arteries as described in methods, because double occlusion of the carotid arteries was necessary to account for residual blood flow via various anastomoses between carotid and vertebral arteries. This resulted in a more severe reduction in cerebral blood flow. The differences in the severity of neuronal cell damage between the control group in the present study and that in a study performed by Gunn and co-worker may be explained by strain and vendor differences (7). In fact, the volume of cerebral infarcts, e.g. in adult rats, depends largely on these variables, a fact that is probably due to differences in the cerebrovascular system $(23,24)$.

After cerebral ischemia there was reactive hyperemia in almost all structures of the fetal brain studied. This reactive hyperemia is largely caused by a reduction in vascular tone on the basis of tissue acidosis during and a decrease in blood viscosity after ischemia $(25,26)$. The hyperemic period was followed by a tendency towards hypoperfusion of the brain. Similar changes in cerebral blood flow could be observed in adult animals after ischemia. However, despite extensive research, the biological significance of this phenomenon is not fully understood (27). In the control group, postischemic brain blood flow at $72 \mathrm{~h}$ was higher than the preischemic blood flow. This phenomenon has also been described in severely asphyxiated human infants (28). Whether this is related to a loss in $\mathrm{CO}_{2}$-reactivity and autoregulation of the cerebral vascular bed due to the ischemic insult is unknown.

As discussed previously the decrease in arterial blood $\mathrm{pH}$ as well as the increase in mean arterial blood pressure and plasma concentrations of both glucose and. lactate are related to the acute experimental animal procedure (10). However, in spite of a few disadvantages of this acute animal model its clear advantage is that total arrest of carotid arterial blood flow could be ensured and controlled visibly.

We conclude that pretreatment by low dose flunarizine ( $1 \mathrm{mg} / \mathrm{kg}$ estimated $\mathrm{BW}$ ) protects the brain of fetal sheep near term from ischemic injury. We further conclude that this neuroprotective effect is not mediated by drug dependent changes in cerebral blood flow. Since low dose flunarizine does not alter the response of the fetal cardiovascular system to 
asphyxia, its clinical use should be reconsidered, particularly in fetuses that are at risk of hypoxic-ischemic encephalopathy.

\section{ACKNOWLEDGEMENTS}

The excellent technical assistance of Otmar Adam, Dorothea Ehler, and Monika Nickel is gratefully acknowledged. This work was supported by Deutsche Forschungsgemeinschaft and by Janssen Pharmatceutica (Beerse, Belgium).

\section{REFERENCES}

1. Volpe JJ 1987 Neurology of the Newborn. Saunders, Philadelphia, pp 314-369

2. Krieglstein J, Oberpichler-Schwenk H 1994 Pharmacology of Cerebral Ischemia.

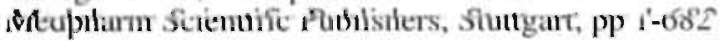

3. Van Reempts J, Borgers M, Van Dael L, van Eyndhoven J, Van de Ven M 1983 Protection with flunarizine against hypoxic-ischemic damage of the rat cerebral cortex. A quantitative morphologic assessment. Arch Int Pharmacodyn Ther 232:7688

4. Silverstein FS, Buchanan K, Hudson C, Johnston MV 1986 Flunarizine limits hypoxia-ischemia induced morphologic injury in immature rat brain. Stroke 17:477482.

5. Gunn AJ, Mydlar T, Bennet L, Faull RLM, Gorter S, Cook C, Johnston BM, Gluckman PD 1989 The neuroprotective actions of a calcium channel antagonist, flunarizine, in the infant rat. Pediatr Res 25:573-576

6. Chumas PD, Del Bigio MR. Drake JM, Tuor UI 1993 A comparison of the protective effect of dexamethasone to other potential prophylactic agents in a neonatal rat model of cerebral hypoxia-ischemia. J Neurosurg 79:414-420

7. Gunn AJ, Williams CE. Mallard EC, Tan WKM, Gluckman PD 1994 Flunarizine, a calcium channel antagonist, is partially prophylactically neuroprotective in hypoxic. ischemic encephalopathy in the fetal sheep. Pediatr Res 35:657-663

8. Gunn AJ, Gluckman PD 1991 Flunarizine, a calcium channel antagonist, is not neuroprotective when given after hypoxia-ischemia in the infant rat. Dev Pharmacol Ther 17:205-209

9. Gunn AJ, Williams CE. Bennet L. Cook CJ, Gluckman PD 1988 Perinatal cerebral asphyxia: pharmacological intervention. Fetal Ther 3:98-107

10. Berger R, Lehmann T, Karcher J, Schachenmayr W, Jensen A 1996 Relation between cerebral oxygen delivery and neuronal cell damage in fetal sheep near term. Reprod Fertil Dev 8:317-321 
11. Todd PA, Benfield P 1989 Flunarizine. A reappraisal of its pharmacological properties and therapeutic use in neurological disorders. Drugs 38:481-499

12. Rudolph AM, Heymann MA 1967 Circulation of the foetus in utero: Methods for studying distribution of blood flow, cardiac output and organ blood flow. Circ Res 21:163-184

13. Brown AW, Brierley JB 1971 Anoxic-ischaemic cell change in rat brain light microscopic and fine structural observations. J Neurol Sci 16:59-84

14. Jensen A, Lang U 1992 Foetal circulatory responses to arrest of uterine blood flow in sheep: effects of chemical sympathectomy. J Dev Physiol 17:75-88

15. Jensen A, Berger R 1991 Fetal circulatory responses to oxygen lack. J Dev Physiol 16:181-207

16. Sakabe T 1989 Calcium entry blockers in cerebral resuscitation. Magnesium 8:238252

17. Siesjö BK, Bengtsson A 1989 Calcium fluxes, calcium antagonists, and calciumrelated pathology in brain ischemia. J Cereb Blood Flow Metab 9:127-140

18. Lu HR, Van Reempis J, Haseldonckx M, Borgers M, Janssen PA 1990 Cerebroprotective effects of flunarizine in an experimental rat model of cardiac arrest. Am J Emerg Med 8:1-6

19. Kumar K, Krause G, Koestner A, Hoehner T, White BC 1987 Effect of flunarizine on global brain ischemia in the dog: a quantitative morphologic assessment. Exp Neurol $97: 115-127$

20. Pulsinelli W, Brierly JB 1979 A new model of bilateral hemispheric ischemia in the unanesthetized rat. Stroke 10:267-272

21. Williams CE, Gunn AJ, Gluckman PD 1991 Time course of iniracellular edema and epileptiform activity following prenatal cerebral ischemia in sheep. Stroke 22:516-52!

22. Blennow M, Zeman J, Dahlin I, Lagercrantz H 1995 Monoamine neurotransmitters and metabolites in the cerebrospinal fluid following perinatal asphyxia. Biol Neonate $67: 407-413$

23. Duverger D. MacKenzie E 1988 The quantification of cerebral infarction following focal ischemia in the rat: influence of strain, arterial pressure, blood glucose concentration, and age. J Cereb Blood Flow Metab 8:440-461

24. Oliff HS. Weber E, Eilon G, Marek P 1995 The role of strain/vendor differences on the outcome of focal ischemia induced by intraluminal middle cerebral artery occlusion in the rat. Brain Res 675:20-26

25. Schmid-Schönbein H 1977 Microrheology of erythrocytes and thrombocytes, blood viscosity and the distribution of blood flow in the microcirculation. In: Altmann HW, Büchner F. Cottier H, eds. Handbuch der Allgemeinen Pathologie III/7: Mikrozirkulation. Berlin: Springer 289-384

26. Takagi S, Cocito L, Hossmann KA 1977 Blood recirculation and pharmacological responsiveness of the cerebral vasculature following prolonged ischemia of the cat brain. Stroke 8:707-712. 


\section{Chapter 5}

27. Hossmann K-A 1993 Ischemia-mediated neuronal injury. Resuscitation 26:225-235

28. Pryds O, Greisen G, Lou H, Friis-Hansen B 1990 Vasoparalysis associated with brain damage in asphyxiated term infants. J Pediatr 117:119-125 


\section{Chapter 6}

\section{CIRCULATORY RESPONSES TO ACUTE ASPHYXIA ARE NOT AFFECTED BY THE GLUTAMATE ANTAGONIST LUBELUZOLE IN FETAL SHEEP NEAR TERM}

Berger R, Garnier Y, Löbbert T, Pfeiffer D, Jensen A Journal of the Society for Gynecologic Invesigation, 2001;8:143-148 


\section{ABSTRACT}

Objective: Asphyxia is one of the main causes of perinatal brain damage that can result in psychomotor deficits during later development. Although over the last decade a number of therapeutic strategies have been developed with successful results in animal experiments, various side effects on the cardiovascular system have precluded their clinical application. However, recently lubeluzole, a new glutamate antagonist, was shown to considerably improve clinical outcome in adults suffering from acute ischemic stroke without any safety concerns. In contrast, preliminary experiments in our laboratory have demonstrated transient alterations in heart rate as well as arterial hypertension after intravenous application of this compound in fetal sheep. The aim of the present study was to examine in detail whether lubeluzole affects circulatory responses to acute asphyxia in fetal sheep near term.

Methods: Eleven fetal sheep were chronically instrumented at a mean gestational age of $133 \pm 2$ (term is at 147 days). The fetuses of the study group $(n=6)$ received three bolus injections of lubeluzole at $30 \mathrm{~min}$ intervals ( $3 \times 0.11 \mathrm{mg} / \mathrm{kg}$ estimated body weight), while the remaining received the solvent. Organ blood flows and physiological variables were measured before, during and after arrest of uterine blood flow for $2 \mathrm{~min}$ (i.e. at $0,1,2,3,4$. and $30 \mathrm{~min}$ ).

Results: Before asphyxia distribution of combined ventricular output and physiological variables in fetuses from the control group were in the normal range for chronically prepared fetal sheep near term. During acute asphyxia there was a redistribution of cardiac output towards the central organs accompanied by a pronounced bradycardia and a progressive increase in arterial blood pressure. There were nearly no differences between groups in the time course of physiological and cardiovascular variables measured before, during and after acute intrauterine asphyxia.

Conclusion: From the present study we conclude that lubeluzole does not affect circulatory responses to acute asphyxia in fetal sheep near term. 


\section{INTRODUCTION}

Asphyxia is one of the main causes of perinatal brain damage that can result in psychomotor deficits during later development $(1,2)$. Over the last decade many therapeutic strategies have been developed to reduce neuronal damage caused by ischemic insults in neonatal and adult animals. Glutamate antagonists in particular have been shown to be highly neuroprotective in various experimental models of cerebral ischemia (3-7). Lubeluzole, a very effective, new glutamate antagonist, considerably improved clinical outcome in patients suffering from acute ischemic stroke (8). Part of its neuroprotective effect may result from inhibition of NO-induced programmed cell death. Thus, lubeluzole decreased DNA fragmentation and annexin- $\mathrm{V}$ binding in primary hippocampal neurons $(9,10)$. Furthermore, $\mathrm{Ca}^{2+}$ channel-blocking properties of lubeluzole might protect neuronal tissue from ischemic injury as shown by patch clamp techniques in isolated rat dorsal root ganglion cells (11). Drug induced side-effects on the cardiovascular system could be excluded in healthy volunteers except for a significant prolongation of cardiac action potential (12-14). Using lubeluzole as a neuroprotective drug might therefore be of potential interest for many perinatologists. However, our preliminary experiments have shown transient alterations in fetal heart rate as well as arterial hypertension after intravenous application of lubeluzole in sheep near term. Thus, it was thought that any possible neuroprotective effect of this drug might be counteracted by an impairment of fetal circulatory centralisation during acute asphyxia, a crucial mechanism that protects the fetal brain from neuronal injury by increasing cerebral perfusion when oxygen is in short supply. The aim of the present study was therefore to examine in detail whether lubeluzole affects circulatory responses to acute asphyxia in fetal sheep near term. For this purpose we arrested maternal uterine blood flow for $2 \mathrm{~min}$ and measured blood flow to fetal organs using the microspheres method.

\section{METHODS}

\section{Animal preparation}

Eleven fetal sheep were chronically prepared at a mean gestational age of $133 \pm 2$ days (term is at 147 days). The surgical preparation has been described previously (15). Briefly, all ewes were anesthetized by subarachnoid injection of $8 \mathrm{ml}$ of $0.75 \%(\mathrm{w} / \mathrm{v})$ bupivacaine at the lower spine, and were operated on under sterile conditions. Polyvinyl catheters were placed into a materna! iliac artery and vein through tibial vessels. The ewe's abdominal wall was opened in the midline and a snare was placed around the descending aorta below the renal artery, which was then used to arrest uterine and ovarian blood flow during the 
experiment. Care was taken not to include any nerves. Fetal catheters were inserted and maintained as described previously (15). An additional catheter was inserted into the amniotic cavity. All catheters were filled with heparin $(1000 \mathrm{JU} / \mathrm{ml})$, plugged, and passed subcutaneously to the ewe's flank, where they were exteriorized and protected by a pouch sewn to the skin. On the day of surgery and each day thereafter, the ewe received 2 million units of penicillin G (Grünenthal, Germany) and $80 \mathrm{mg}$ of gentamycin sulfate (Merck, Germany), half i.v. and half into the amniotic cavity. The fetuses, were allowed to recover for 2 days before being studied. As shown in a variety of previous experiments performed in our laboratory blood gases, cardiovascular variables and plasma catecholamines are within the normal range for chronically prepared fetal sheep near after this time period $(16,17)$.

\section{Experimental protocol}

After taking control measurements of the physiological variables, 6 of the 11 fetuses received three bolus injections of lubeluzole at $30 \mathrm{~min}$ intervals $(3 \times 0.1 \mathrm{l} \mathrm{mg} / \mathrm{kg}$ estimated fetal body weight), while the remaining received the solvent. We preferred this application regimen to a single bolus injection of $0.33 \mathrm{mg} / \mathrm{kg}$ estimated fetal body weight, since the latter was found to produce cardiovascular side effects. The drugs were donated by Janssen Pharmaceutica, Beerse, Belgium. Sixty minutes later (at 0 min) uterine blood flow was arrested by a single occlusion of the descending aorta for 2 min to induce acute fetal asphyxia. To determine the effects of lubeluzole on the time course of circulatory centralization before, during and after acute asphyxia, blood flow to fetal organs and the distribution of combined ventricular output were measured by injecting six batches of differently labeled isotope microspheres $\left({ }^{141} \mathrm{Ce},{ }^{114} \mathrm{In},{ }^{113} \mathrm{Sn},{ }^{103} \mathrm{Ru},{ }^{95} \mathrm{Nb} \&{ }^{46} \mathrm{Sc}, 161 \mu \mathrm{m}\right.$ diam., New England Nuclear) into the inferior vena cava (18,19). Depending on the activity, 0.7 to 2.8 million microspheres per batch were applied. Asphyxia was caused by arresting uterine blood flow with the snare. Microspheres were injected at $75 \mathrm{~s}$ before asphyxia (control measurement), at 1 and 2 min during arrest of uterine blood flow, and at 1, 2, and 28 min after release of the snare (recovery period). Reference blood samples were withdrawn from both a carotid and a femoral artery at a rate of $2.5 \mathrm{~mL} / \mathrm{min}$. Sampling was continuous for $270 \mathrm{~s}$ during control, occlusion and the immediate recovery period. Separate samples were taken for $75 \mathrm{~s}$ during the 28 -min recovery measurement. The volume of blood withdrawn was about $25 \mathrm{~mL}$ and was simultaneously replaced by maternal blood maintained at $39^{\circ} \mathrm{C}$ in a waterbath. When using the microspheres method to measure blood flow at $1-2$ min intervals the sampling time for reference blood must be adequate and the number of microspheres still circulating 30 to $40 \mathrm{~s}$ after each injection 
must be negligible. As shown previously these conditions are fulfilled in the present experimental set up (15).

The experimental protocols including all anesthesiological and surgical procedure were approved by the appropriate institutional review committee and met the guidelines of the responsible governmental agency (Regierungspräsidium Gießen, Germany).

\section{Measurements}

Fetal heart rate and arterial blood pressure, amniotic fluid pressure, and maternal arterial blood pressure were recorded on a polygraph (Hellige, Germany) during the experiment. Complete occlusion of the ewe's descending aorta by means of the snare throughout the 2min study period was confirmed by the fall in maternal arterial blood pressure distal to the obstruction. Before blood flow was measured, a blood sample was taken from the descending aorta and analysed for blood gases, acid-base balance (278 Blood Gas System, Ciba Corning, Frankfurt, Germany), hemoglobin concentration, oxygen saturation (OSM 2 Hemoximeter, Radiometer, Copenhagen, Denmark), glucose and lactate concentrations.

After the experiment a lethal dose of sodium pentobarbitone was given to the ewe and the fetuses were perfused with $300 \mathrm{ml}$ of formalin $(15 \%$, w/v, saline). Fetal organs and cotyledons were weighed and placed in vials, which were filled to the same height to reduce variations in geometry. The intestines were separated from the mesentery, opened, and cleared of contents. Paired organs (lungs, kidneys, and adrenals) were counted separately, as were the right and left sides of the cerebrum and of the brainstem regions. No significant preferential streaming of microspheres was found. Specimens of skin and muscle were taken from the hips and shoulders of each side. There were no differences in blood flow between the intact side and the side on which the femoral or brachial arteries had been catheterized.

The applied solid-state semi-conductor germanium (Ge) gamma counter had a high energy resolution of about $3 \mathrm{keV}$ and was connected to a multichannel (2048) pulse height analyzer (ND 62, Nuclear Data Inc., Illinois, USA). The results were normalized with respect to time and sample weight. 


\section{Chapter 6}

\section{Calculations}

Blood flow to the various fetal organs were calculated from counts of the injected nuclide recovered in fetal organs or the placenta, from counts in the appropriate reference samples, and from the withdrawal rate of the reference sample $(18,19)$. To determine combined cardiac output absolute blood flows to all fetal organs including the placenta were added together and then divided by fetal body weight. Portal venous blood flow was calculated from the sum of the actual blood flow to each gastro-intestinal organ, including stomach, intestines, mesentery, pancreas, and spleen. The percentage of combined ventricular output distributed to a given organ was calculated from the absolute blood flow to that organ and the combined ventricular output. The vascular resistance was calculated by dividing arterial blood pressure (corrected for amniotic fluid pressure) by blood flow and was expressed in $\mathrm{mmHg} / \mathrm{ml} / \mathrm{min} / 100 \mathrm{~g}$ of tissue. Blood flow inferior to $1 \mathrm{ml} / \mathrm{min} / 100 \mathrm{~g}$ was treated as $\mathbf{1}$. Umbilical vascular resistance $(\mathrm{mmHg} / \mathrm{ml} / \mathrm{min} / \mathrm{kg}$ fetal weight) was calculated by dividing the perfusion pressure of the umbilical circulation (arterial blood pressure minus the estimated umbilical venous blood pressure before $(11 \mathrm{mmHg}$ ) and during (17 $\mathrm{mmHg}$ ) reduction in uterine blood flow (20)) by umbilical blood flow.

\section{Statistics}

Resulis are given as means $\pm \mathrm{SD}$. The data were analysed for intra- and intergroup differences by two-way multivariate analysis of variance for repeated measures. The Games-Howell-test was used as a post-hoc testing procedure. Statistical analysis was. performed by the Super Anova Statistical Package (Abacus, Inc. Ca., USA).

\section{RESULTS}

Control group

During the control period combined ventricular output, heart rate, arterial blood pressure. blood gases, pH, glucose, lactate and plasma concentrations of catecholamines were in the normal range for chronically prepared fetal sheep near term (21). Arrest of uterine blood flow for 2 min decreased fetal heart rate, arterial $\mathrm{O}_{2}$ saturation of hemoglobin, and $\mathrm{pH}$, and increased fetal arterial blood pressure, $\mathrm{pCO}_{2}$, and plasma concentrations of lactate (Tables 1 and 2).

After $1 \mathrm{~min}$ of asphyxia combined ventricular output fell by $51 \%$ (Table 2). Whereas the portion distributed to placenta, heart, and brain increased by $57 \%, 431 \%$, and $87 \%$ respectively, that to the adrenals did not change significantly. Within the brain there was a 
preferential rise in percent cardiac output distributed to the brainstem. In contrast, blood flow to the choroid plexus decreased (Table 3). After 2 min of asphyxia combined ventricular output was reduced by $57 \%$ (Table 2 ), but the portion distributed towards central organs was raised further (heart $905 \%$, brain $166 \%$, adrenals $414 \%$ ).

Table 1. Acid-Base Balance and Blood Gases in Control and Lubeluzole-Treated Term Fetal Sheep.

\section{Groups Control Asphyxia 1 Asphyxia 2 Recovery 3 Recovery 4 Recovery 30}

pH

$\begin{array}{lllllll}\text { C } & 7,40 \pm 0,04 & 7,38 \pm 0,03 & 7,30 \pm 0,02 \text { f } & 7,28 \pm 0,08 \text { f } & 7,30 \pm 0,05 \text { f } & 7,33 \pm 0,04 \text { e } \\ \text { L. } & 7,41 \pm 0,03 & 7,37 \pm 0,03 & 7,27 \pm 0,02: \text { f } & 7,27 \pm 0,04 \text { f } & 7,29 \pm 0,04 \text { f } & 7,33 \pm 0,04 \text { f }\end{array}$

Oxygen Saturation (\%)

$\begin{array}{lllllllllll}\text { C } & 54,0 \pm 8,1 & 14,2 \pm 8,7 & \text { f } & 4,8 \pm 3,9 & \text { f } & 25,7 \pm 11,6 \text { f } & 43,2 \pm 8,9 & \text { d } & 48,8 \pm 10,8 \\ \text { L } & 64,3 \pm 5,2 & 19,1 \pm 8,5 & \text { f } & 5,0 \pm 1,9 & \text { f } & 31,1 \pm 5,5 \quad \text { f } & 46,2 \pm 4,6 & \text { f } & 50,0 \pm 8,2\end{array}$

p(), (mmHg)
C $\quad 21,8 \pm 2,7$
$10,2 \pm 2,6 \quad f$
$5,5 \pm 2,2 \mathrm{f}$
$16,9 \pm 4,9$ d $23,6 \pm 3,3$
$24,3 \pm 3,0$
I. $21,9 \pm 1,9$
$9,0 \pm 4,1 \quad f$
$2,1 \pm 1,9 \mathrm{f}$
$15,3 \pm 2,2$ f $20,0 \pm 2,4$
$19,5 \pm 2,6$

\section{p(') $\left(\mathrm{mmHg}_{2}\right)$}
C $\quad 47,4 \pm 2,6$
$51,4 \pm 2,8$
$62,8 \pm 6,3\}$
$63,9 \pm 9,2$ f
$57,9 \pm 7,4$ e
$50,0 \pm 3,2$
L $\quad 46,5 \pm 2,2$
$50,9 \pm 3,5$
$64,3 \pm 5,3 \mathrm{f}$
$61,3 \pm 5,3$
$56,0 \pm 4,4$ e
$48,7 \pm 2,5$

\section{Hemoglohin (g/dil)}
C $\quad 10,8 \pm 0,8$
$11,5 \pm 0,9$
$13,0 \pm 1,2$ f $12,6 \pm 1,1$ f
$11,7 \pm 1,0$
$10,4 \pm 1,2$
L. $\quad 11,6 \pm 0,5 \quad 12,4 \pm 0,4$
$14, I \pm 0,5$ af $13,5 \pm 0,3$ if
$12,9 \pm 0,5$ a,e
$11,4 \pm 0,5$ a

Glucose (mg/ml)

\begin{tabular}{|c|c|c|c|c|c|}
\hline $21,4 \pm 4,6$ & $21,8 \pm 3,8$ & $19,0 \pm 2,2$ & $21,0 \pm 3,5$ & $25,4 \pm 4,3$ & $28,8 \pm 5,3$ \\
\hline $20,0 \pm 3,3$ & $2 I, 5 \pm 5, I$ & $18,7 \pm 2,6$ & $19,2 \pm 4,1$ & $24,3 \pm 4,8$ & $22,5 \pm 4,5$ \\
\hline
\end{tabular}

\section{Lactate (mmoll])}

C $\quad 1,64 \pm 0,3$

$1,74 \pm 1,6$

$2.78 \pm 0.5$ d

$3.63 \pm 0,7 \quad f$

$3,69 \pm 0,6 \quad \mathrm{f}$

$4,42 \pm 0,8$ f

L. $\quad 1,49 \pm 0,4$

$1,92 \pm 0,0$

$2,96 \pm 1,0$ e $4,03 \pm 1,2$ f

$4,14 \pm 1,0$

$4,03 \pm 1,5 \quad f$

$a<0,05, b<0,01, c<0,001$ significant between groups: $\mathrm{d}<0,05, \mathrm{e}<0,01, \mathrm{f}<0,001$ significant versus control within groups $\mathrm{C}=$ control fetuses $(\mathrm{n}=5), \mathrm{L}=$ treated (lubeluzole) fetuses $(\mathrm{n}=6)$ 
In the immediate recovery period, i.e. 1 and $2 \mathrm{~min}$ after arrest of uterine blood flow had been released, arterial blood pressure was still high (Table 2) and blood flow to the heart and all parts of the brain was increased (Table 3). At $30 \mathrm{~min}$, i.e. after $28 \mathrm{~min}$ recovery, these values were not different from control. In all peripheral organs of the upper and lower body segment, including the carcass, skeletal muscle, total gastro-intestinal tract and portal vein, kidneys, spleen, scalp, and body skin, the proportion of combined ventricular output and actual blood flow decreased to very low values during asphyxia, and recovered gradually thereafter (Table 3 ).

Table 2. Changes of Physiologic Variables and Blood Flow in Control and Lubeluzole-Treated Fetal Sheep Near Term.

\begin{tabular}{|c|c|c|c|c|c|c|c|c|}
\hline Group & Control & Asphiyxia I & & Asphyxia 2 & Recovery 3 & & Recovery 4 & Recovery 30 \\
\hline \multicolumn{9}{|c|}{ Fetal Heart Rate (bpm) } \\
\hline $\mathrm{C}$ & $145.4 \pm 13,5$ & $93,8 \pm 17,4$ & d & $96,9 \pm 30,4$ & $159.4 \pm 82.5$ & & $143,1 \pm 36,5$ & $168,0 \pm 63.5$ \\
\hline 1. & $138.3 \pm 25.2$ & $59.2 \pm 23.1$ & f & $80.0 \pm 23.7 \mathrm{~d}$ & $124,2 \pm 57,2$ & & $104.2 \pm 15.0$ & $144,2 \pm 13,2$ \\
\hline \multicolumn{9}{|c|}{ Arterial Blood Piressure $(\mathrm{mmHg})$} \\
\hline C & $47,5 \pm 5,3$ & $57.7 \pm 6.3$ & d & $71,7 \pm 12,7 \mathrm{f}$ & $80.2 \pm 12.4$ & f & $73,9 \pm 7,2 \quad i$ & $48.5 \pm 5,1$ \\
\hline 1. & $53,2 \pm 7,1$ & $55,4 \pm 5,9$ & & $82,6 \pm 5,2$ f & $87,5 \pm 5,9$ & f & $78,3 \pm 5,5 \quad f$ & $5,8,8 \pm 4,7$ \\
\hline \multicolumn{9}{|c|}{ Stroke Volume } \\
\hline C & $3,6 \pm 0,3$ & $2,8 \pm 0.4$ & & $2,7 \pm !, 6$ & $2,9 \pm 1,4$ & & $3.2 \pm 0.7$ & $2,9 \pm 2,0$ \\
\hline 1. & $4,3 \pm 0,9$ & $4.6 \pm 1.3$ & $a$ & $3.0 \pm 0.9$ & $4,8 \pm 2,0$ & a & $4,3 \pm 0,5$ & $4.5 \pm 1.2$ \\
\hline
\end{tabular}

Blood Flow (mV/min $\mathrm{x}$ kg fetus)

\begin{tabular}{|c|c|c|c|c|c|c|c|}
\hline \multicolumn{8}{|c|}{ Cardlac Output } \\
\hline C & $536,6 \pm 52,0$ & $265,3 \pm 43,8$ & $\mathrm{e}$ & $232,6 \pm 50,9 f$ & $42.4,3 \pm 140,5$ & $444,5 \pm 59,7$ & $485,7 \pm 320.3$ \\
\hline I. & $577.1 \pm 67.5$ & $279.9 \pm 36.1$ & $f$ & $222.9 \pm 27.8 \mathrm{f}$ & $525.0 \pm 87.7$ & $446.4 \pm 83.7$ & $637.8 \pm 122,0$ \\
\hline \multicolumn{8}{|c|}{ Placenta } \\
\hline C & $207,1 \pm 21,9$ & $167.1 \pm 33,2$ & & $88.5 \pm 68.9$ e & $179,2 \pm 107.7$ & $195,6 \pm 70.2$ & $187,6 \pm: 113,4$ \\
\hline i. & $221,6 \pm 21,5$ & $179,7 \pm 43,4$ & & $84,8 \pm 19,7 e$ & $169.2 \pm 51.0$ & $158.3 \pm 73.3$ & $230.0 \pm 112.3$ \\
\hline \multicolumn{8}{|c|}{ Fetal Body } \\
\hline C & $329.5 \pm 42,6$ & $98.2 \pm 37.4$ & i & $144.1 \pm 38.8 \mathrm{e}$ & $245,1 \pm 36,8$ & $249,0 \pm 41.5$ & $298.1 \div 212.3$ \\
\hline 1. & $355,5 \pm 67,1$ & $100,2 \pm 26,3$ & I & $138.1 \pm 20,7 \mathrm{f}$ & $355,8 \pm 96,9$ & $288,1 \pm 51.9$ & $407.8 \pm 74.3$ \\
\hline
\end{tabular}

a< $0,05, b<0,01, \propto<0,001$ significant between groups; $d<0,05, \propto<0,01, f<0,001$ significant versus control within groups $\mathrm{C}=$ control fetuses $(\mathrm{n}=5), \mathrm{L}=$ treated (lubeluzole) fetuses $(\mathrm{n}=6)$ 
Table 3. Organ Blood Flow in Control and Lubeluzole-Treated Fetal Sheep Near Term

Bleod fow $\left(\mathrm{ml} / \mathrm{min} / 10 \mathrm{~g}_{\mathrm{g}}\right)$

Groep Control Asphyxia 1 Asphysia $2^{*}$ Recevery $y$ Recovery 4 Recovery 30 :

Heart

C $\quad 215.7 \neq 68.5 \quad 616.3 \neq 293.2$ e $884.9=264.0$ f $904.5 \neq 321.6$ f $693.4 \neq 313.2$ f $418.6 \neq 206.4$

l $\quad 246.2=72.5 \quad 458.9=199.3 \quad 755.5=92.7$ f $670.4=227,3$ f $424,1=147.7 \quad 427.3 \neq 131.2$

Brain

C $\quad 205.5=25.9 \quad 199,6=53,6 \quad 231.0 \neq 4 ., 0$

$|84|=.45.9 \quad 179.3=22.6 \quad 212.0=17.7$

$361.5=54.8$ f $345,2=33,0$ f $188.3 \neq 47,9$

$360.8=55.2$ f $379.0=65.3$ f $245.8=79.8$

\section{Cerebrum}

C $\quad 186,6=27.9$

$159.0=39.3$

$182.1=28.6$

$310.6 \pm 54.3$ if $296.6 \pm 37.6$ i $167.2=41.3$

L. $\quad 164.2 \neq 35,1$

$135,4=10,4$

$162.9=25.5$

$303.2+41,1$ f $314,9 \neq 49,6$ f $200,2 * 68,2$

\section{Cerebellum.}

C $236.7=18.8$

$269.7 \geq 66.3$

$235,5 \neq 46.0$

$243,4=49,7$

$302,1=58.3$

$463,0=90,9$ f $445,8=40,8$ i $240,5=79,1$

$267.2 \neq 50.8$

$44,7 \pm 68.6$ i $503,6 \neq 82,0$ i $317,2=83,0$ d

\section{Brainstem}

C $2815 \div 38,1$

$228.3 \pm 94,6 \quad 330,7 \pm 76.8$

$460,9=111,3$ e $593,8=67,0$ f $566,9=59,0$ f $266,7=66,1$ $394.2 \pm 17.0$ e $563.2 \pm 99.0$ f $593.3 \pm 115.4$ f $348,1 \pm 13 t .5$ d

Choroid plexus

C $\quad 555.7 \pm 183.5$

l. $7+2.7 \pm 276,2$

$78.8 \pm 28.3$

$71.9 \pm 9.4$

$129.6 . \pm 54,6$ f $121,4 \pm 54,7$ f $460,0 \pm 193,2$

\section{Hippocampus}

C $\quad 175.7 \pm+1.8$

L. $144.9 \pm 37.8$

$196,8 \pm 58,2$

$238.8 \pm 46.1$

$335,7 \pm 44,7$ f $313,4 \pm 65,0$ \& $201.2 \pm 64.9$

$131,7 \pm 24.8$

$180.2 \pm 39.0$

$326.9 \pm 44,3$ if $305,6 \pm 34,2$ if

$197,8 \pm 82,4$

Adresenl

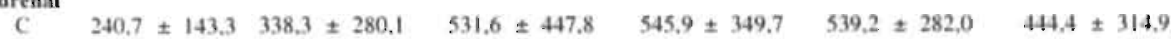

L. $\quad 414.0 \pm 144.9 \quad 427,4 \pm 164.2 \quad 558,3 \pm 93,2 \quad 366,8 \pm 175,0 \quad 408,0 \pm 156,7 \quad 436,6 \pm 224,0$

\section{Kidney}
C $\quad 180.1 \pm 36.6$
$30.6 \geq 11.3$
$9.9 \pm 9,0$
$39.9 !+20.8-f$
$69.2 \pm 16,3 \quad$ i $\quad 162,7 \pm 36,1$
L. $\quad 214.9 \pm 27.2$
$62.0 \pm 25.9$
$5.2 \pm 3.6$
$49.5 \pm 22.9$
$67.8 \pm 33.7$ i $178.0 \pm 81.8$

\section{Gastrointestinal trace}

C $83,4 \pm 17,9$

L $\quad 99.7 \pm 31.4$

$2.3 \pm 1.7 \quad$ f
$4.9=10.0$ if
$2.5 \pm 5.6$

$39.51=16.51$

$50,3 \pm 6,3$

$82,1=40,4$

Liver, arterial
C. $\quad 4.6=4.7$
$2.1 \pm 2.5$
$7.6 \pm 7,7$
$7.1 \pm 6.1$
$5,3 \pm 3.7$
$4,4 \pm 3,4$,
$5.2 \pm 2.5$
$0.9 \pm 0.7$
$1.6 \pm 0.9$
$4.5=1.3$
$3,3=1.5$
$7,0 \pm 5,3$

Portal Vein
C $\quad 87.3 \pm 18.2$.

$2.3=1.7$

$6.4 \pm 5.4$

$39.9 \pm 17.5$

L $\quad 109.4 \pm 31.6$.

$4.6 \pm 9.3$

$2.5 \pm 1.4$

Spleen

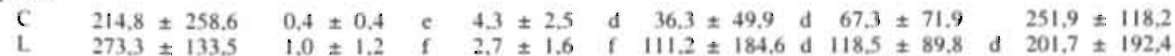

Scalp

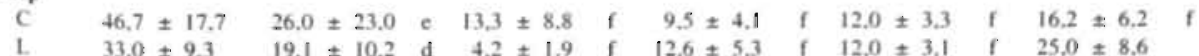

Carcass
C
$26,8 \pm 3,8$
$3.5 \pm 1.4$
$3.2 \pm 0.7$
$9.3 \pm 2.6$
$10.9 \pm 1.5$
$16,9 \pm 5,2$
L $\quad 26,9 \pm 3,7$.
$3.5 \pm 0.8$ f $\quad 3.7 \pm 0.6$
$14.3 \pm 5.0$
f $15,6 \pm 4,1$
$18,8 \pm 3,8$

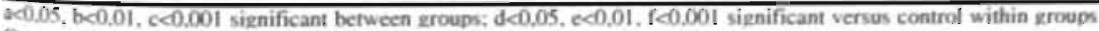

$\mathrm{C}=$ control fetuses $(n=5 \mathrm{i}, \mathrm{L}=$ treatod (lubeluzole) fetuses $(n=6)$ 


\section{Study group}

Fetal heart rate and mean arterial blood pressure were measured 1 min before and $5 \mathrm{~min}$ after the three bolus injections of lubeluzole. Application of the drug did not cause any significant changes in these two variables (Table 4). Furthermore, the data from the control and study groups did not differ significantly (Tables 1-3) except for some marginal differences in hemoglobin, stroke volume, percentage cardiac output to the brainstem and thalamus, and vascular resistance of the hippocampus and brainstem (data not shown).

Table 4. Fetal Heart Rate (FHR) and Mean Arterial Blood Pressure (MAP) 1 Minute Before $(-1 \mathrm{~min})$ and 5 minutes $(+5$ min) After Three Bolus Injections of Lubeluzole in Fetal Sheep Near Term

\begin{tabular}{|c|c|c|}
\hline Injection & FHR (bpm) & MAP (mmHg) \\
\hline \multicolumn{3}{|l|}{ 1st } \\
\hline$-1 \mathrm{~min}$ & $153 \pm 14$ & $49 \pm 8$ \\
\hline$+5 \mathrm{~min}$ & $147 \pm 14$ & $52 \pm 9$ \\
\hline \multicolumn{3}{|l|}{ 2nd } \\
\hline$-1 \mathrm{~min}$ & $150 \pm 17$ & $50 \pm 7$ \\
\hline$+5 \mathrm{~min}$ & $147 \pm 11$ & $53 \pm 6$ \\
\hline \multicolumn{3}{|l|}{$3 r d$} \\
\hline$-1 \mathrm{~min}$ & $144 \pm 10$ & $49 \pm 8$ \\
\hline$+5 \mathrm{~min}$ & $138 \pm 15$ & $52 \pm 5$ \\
\hline
\end{tabular}

\section{DISCUSSION}

The central finding of the present study is that circulatory responses to acute asphyxia are not impaired by lubeluzole in fetal sheep near term. Before asphyxia, the distribution of combined ventricular output and physiological variables in fetuses from the control group were in the normal range for chronically prepared fetal sheep near term. During acute asphyxia there was a redistribution of cardiac output towards the central organs accompanied by pronounced bradycardia and a progressive increase in arterial blood pressure. After asphyxia circulatory centralization did not resolve quite as rapidly as it had developed, but was almost completely recovered at $30 \mathrm{~min}$ after the insult. This pattern of redistribution of cardiac output is very similar to those observed during maternal hypoxemia and umbilical cord occlusion $(22,23)$. Whereas fractions of cardiac output distributed to the brain, heart, and adrenals increase, those to the peripheral organs fall 
drastically. However, arresting uterine blood flow has some effects not seen in the other models, for example cardiac output falls markedly. Furthermore, there are differences in actual cerebral vascular resistance and in both blood flow and oxygen delivery to the brain, in that cerebral blood flow does not rise. Thus, oxygen delivery to the cerebrum falls, whereas that to the brainstem is maintained, reflecting a redistribution of brain blood flow in favour of brainstem areas (21). For the present study we preferred this model of fetal asphyxia, since in our laboratory almost all investigations on fetal cardiovascular mechanism have been performed in this experimental set up. This enables us to compare the newly obtained data to the results of our previous experiments.

Although preliminary experiments in our laboratory have shown sporadic alterations in fetal heart rate as well as arterial hypertension after intravenous application of lubeluzole in sheep near term, these observations could not be confirmed in the present study. As shown in Table 4, bolus injections of lubeluzole did not have any significant effects on fetal heart rate and mean arterial blood pressure. In addition, hardly any differences were observed between groups in the time course of physiological and cardiovascular variables measured before, during and after acute intrauterine asphyxia. Furthermore, it should be emphasized that in neither the treated nor the untreated fetuses did cerebral blood flow rise during asphyxia despite an increase in arterial blood pressure, suggesting that during acute asphyxia cerebral autoregulation was maintained and was not affected by lubeluzole. However, one might speculate that effects of lubeluzole on the fetal cardiovascular system could become evident after longer periods of asphyxia. Although the asphyxic insult in the present study lasted only $2 \mathrm{~min}$, its severity is already considerable. Thus, at the end of asphyxia arterial oxygen saturation was nearly zero and combined ventricular output was reduced by $57 \%$. As shown in one of our earlier studies, prolonging the asphyxic period for only two further minutes resulted in death of more than $50 \%$ of the fetusus within 10 to 35 min after the arrest of uterine blood flow was released (I5). It is therefore obvious that under such experimenta! conditions pharmacological testing would not seem to be very sensible. To study the effects of lubeluzole on prolonged asphyxic periods an animal model, in which uterine blood flow is gradually reduced, has to be used.

The concentration of lubeluzole used in the present study was within the same range as that applied in previous investigations. In humans the injected dose lay between 2.5 and 25 $\mathrm{mg} / \mathrm{d}$, i.e. about 0.036 to $0.36 \mathrm{mg} / \mathrm{kg} / \mathrm{d}(24-26)$, in rats lubeluzole was applied at a concentration of between 0.62 and $0.8 \mathrm{mg} / \mathrm{kg}(4,7,27)$. In vitro studies have even shown that lubeluzole has neuroprotective effects down to the pM range (molecular weight: $433,52 \mathrm{~g} / \mathrm{Mol}$ ) (5). As demonstrated in patients with acute ischemic stroke the mean distribution half-life of lubeluzole is $101 \mathrm{~min}$ and the mean terminal half-live $27.7 \mathrm{~h}$, if the 
drug is applied intravenously at a dose of $15 \mathrm{mg}$ (24). Thus, in the present study the concentration of lubeluzole was within the therapeutic range and possible effects on the fetal cardiovascular system should have become evident during the observation period.

From the present study we conclude that lubeluzole does not affect circulatory responses to acute asphyxia in fetal sheep near term. These results are encouraging enough to justify designing in vivo experiments to test the neuroprotective properties of this drug.

\section{ACKNOWLEDGEMENTS}

The excellent technical assistance of Otmar Adam, Dorothea Ehler and Monika Nickel is gratefully acknowledged. This work was supported by Deutsche Forschungsgemeinschaft and By Janssen Pharmaceutica (Beerse, Belgium).

\section{REFERENCES}

I. Volpe JJ. Neurology of the newborn. Philadelphia: WB Saunders, 1995

2. Berger R, Gamier Y. Pathophysiology of perinatall brain damage. Brain Res Brain Res Rev 1999:32:107-34

3. De Ryck M, Keersmaekers R, Duytschaever H, Claes C, Clincke G, Janssen M, Van Reet G. Lubeluzole protects sensorimotor function and reduces infarct size in a photochemical stroke model in rats. J Pharmacol Exp Ther 1996:279:748-58

4. Haseldonckx M. Van Rempts J, Van de Ven M, Wouters L, Borgers M. Protection with lubeluzole against delayed ischemic brain damage in rats. A quantitative histopathologic study. Stroke 1997:28:428-32

5. Culmsee C. Junker V, Wolz P. Semkova. I, Krieglstein J. Lubeluzole protects hippocampai neurons from excitatoxicity in vitro and reduces brain damage caused by ischemia. Eur J Pharmacol 1998:342:193-202

6. Wiedemann M, Hanke W. Lubeluzole shows neuroprotective effects in an "in-vitro"model for neuronal lesions in the chicken retina. Brain Res 1998:842:243-8

7. DeRyck M, Verhoye M, Van der Linden. Diffusion-weighted MRI of infarct growth in a rat photochemical stroke model: effect of lubeluzole. Neuropharmacology 2000:14:691-702

8. Grotta J. Lubeluzole treatment of acute ischemic stroke. The US and Canadian Lubeluzole Ischemic Stroke Study Group. Stroke 1997:28:2338-46

9. Maiese K. Vincent AM. Membrane asymmetry and DNA degradation: functionally distinct determinants of neuronal programmed cell death. J Neurosci Res 2000:59:56880 
10. Maiese K, Vincent AM. Critical temporal modulation of neuronal programmed cell injury. Cell Mol Neurobiol 2000;20:383-400

11. Marrannes R, De Prins E, Clincke G. Influence of lubeluzole on voltage-sensitive Ca** channels in isolated rat neurons. J Pharmacol Exp Ther 1998;286:201-14

12. Hacke W, Lees KR, Timmerhuis T, Haan J, Hanston L, Hennerici M, Diener HC. Cardiovascular safety of lubeluzole (Prosynap(i)) in patients with ischemic stroke. Cerebrovasc Dis 1998;8:247-54

13. Le Grand B, Dordain-Maffre M, John GW. Lubeluzole-induced prolongation of cardiac action potential in rabbit Purkinje fibres. Fundam Clin Pharmacol 2000;14:159. 62

14. Herron J, Lee P, Pesco-Koplowitz L, Gajjar D, Soo YW, Woestenborghs R. Determination of the dose proportionally of single intravenous doses $(5,10$, and 15 $\mathrm{mg}$ ) of lubeluzole in healthy volunteers. Clin Ther 1998;20:682-90

15. Jensen A, Hohmann M. Künzel W. Dynamic changes in organ blood flow and oxygen consumption during acute asphyxia in fetal sheep. I Dev Physiol 1987;9:543-59

16. Jensen A, Lang U. Foetal circulatory responses to arrest of uterine blood flow in sheep: effects of chemical sympathectomy. J Dev Physiol 1992;17:75-86

17.Jensen A, Hanson MA. Circulatory responses to acute asphyxia in intact and chemodevernated fetal sheep near term. Reprod Fertil Dev 1995;7:1351-9

18. Rudolph AM, Heymann MA. Circulation of the fetus in utero: Methods for studying distribution of blood flow, cardiac output and organ blood flow. Circ Res 1967;21:16384

19. Heymann MA, Payne BD, Hoffman JIE, Rudolph AM. Blood flow measurements with radionuclide-labeled particles. Prog Cardiovasc Dis 1977;20:55-79

20. Jensen A, Roman C, Rudolph AM. Effects of reducing uterine blood flow on fetal blood flow distribution and oxygen delivery. J Dev Physiol 1991;15:309-23

21.Jensen A, Berger R. Fetal circulatory responses to oxygen lack. J Dev Physiol 1991:16:181-207

22.Cohn HE, Sacks EJ, Heymann MA, Rudolph AM. Cardiovascular responses to hypoxemia and acidemia in fetal lambs. Am J Obstet Gynecol 1974;120:817-24

23. Itskovitz J, LaGamma EF, Rudolph AM. Effects of cord compression on fetal blood flow distribution and O2 delivery. Am J Physiol 1987;252: H100-H9

24. De Keyser J, van de Velde V. Schellens RLLA, Hantson L, Tritsmans L, Gheuens J, van Peer A, Woestenborghs R, Franke CL, van Gorp J. Safety and pharmacokinetics of the neuroprotective drug lubeluzole in patients with ischemic stroke. Clin Ther 1997:19:1340-51

25. Grotta J. Lubeluzole treatment of acute ischemic stroke. The US and Canadian. Lubeluzole Ischemic Stroke Study Group. Stroke 1997;28:2338-46 
26. Diener HC. Multinational randomised controlled trial of lubeluzole in acute ischaemic stroke. European and Australian Lubeluzole Ischaemic Stroke Study Group. Cerebrovasc Dis 1998;8:172-81

27. Kroppenstedt SN, Siroop R, Kern M, Thomale UW, Schneider GH, Unterberg AW. Lubeluzole following traumatic brain injury in the rat. I Neurotrauma 1999;16:629-37 


\section{Chapter 7}

\section{LUBELUZOLE PRETREATMENT DOES NOT PROVIDE NEURO- PROTECTION AGAINST TRANSIENT GLOBAL CEREBRAL ISCHEMIA IN FETAL SHEEP NEAR TERM}

Garnier Y, Löbbert T, Jensen A, Berger R

Pediatric Research, 2002;51:517-522 


\section{ABSTRACT}

The aim of the present study was to test the neuroprotective effect of the novel benzothiazol compound lubeluzole on neuronal cell damage in fetal sheep arising from global cerebral ischemia. Thirteen fetal sheep were prepared at a mean gestational age of $127 \pm 1 \mathrm{~d}$ (term is at $147 \mathrm{~d})$. Six fetuses were treated with lubeluzole $(0.33 \mathrm{mg} / \mathrm{kg}$ estimated body weight) before induction of global cerebral ischemia $(-90,-60$, and -30 $\min )$, while the remainder $(n=7)$ received solvent. Cerebral ischemia was induced by occluding both carotid arteries for $30 \mathrm{~min}$. Cerebral blood flow was measured by injecting radio-labelied microspheres before ( $-90 \mathrm{~min})$, during $(+3 \mathrm{~min}$ and $+27 \mathrm{~min}$ ) and after $(+40$ $\min ,+3 \mathrm{~h}$, and $+72 \mathrm{~h}$ ) cerebral ischemia. Neuronal cell damage was assessed in the cerebrum and deeper brain structures by light microscopy. Values are given as means \pm SD. In control fetuses blood flow to the cerebrum was reduced from $100 \pm 25 \mathrm{~mL} \cdot 100 \mathrm{~g}$ ' $\mathrm{min}^{-1}$ to less than $20 \mathrm{~mL} \cdot 100 \mathrm{~g}^{-1} \mathrm{~min}^{-1}$ during ischemia. Shortly after ischemia hyperperfusion occurred $\left(217 \pm 66 \mathrm{~mL} \cdot 100 \mathrm{~g}^{-1} \mathrm{~min}^{-1}\right)$ followed by a tendency towards hypoperfusion $\left(72 \pm 17 \mathrm{~mL} \cdot 100 \mathrm{~g}^{-1} \min ^{-1}\right)$ later on $(+3 \mathrm{~h})$. Significant differences in blood. flow to the various brain structures between the control and study groups could not be observed. Neuronal cell damage was concentrated in the parasagittal regions of the cerebrum. Pre-ischemic application of lubeluzole did not have any effect on the extent of neuronal cell damage. From these results we conclude that pretreatment with lubeluzole fails to protect the brain of fetal sheep near term from injury after transient global cerebral ischemia. However, since the observation period lasted only 3 days, a possible effect of lubeluzole on pathophysiological mechanisms inducing delayed neuronal cell death can not be fully excluded. 


\section{INTRODUCTION}

Hypoxic-ischemic cerebral damage is an important contributor to perinatal mortality and morbidity including long-term neurologic sequelae in term and preterm fetuses (1). Although over the last decade many therapeutic strategies have been developed in various animal models to reduce neuronal cell damage caused by ischemic insults, their clinical application has often been rejected due to major drug related side-effects (2). Especially after application of calcium antagonists and inhibitors of nitric oxide synthase alterations of fetal cardiovascular control have been observed $(3,4)$. However, the recently developed benzothiazole compound lubeluzole seems to justify further research in this field. The neuroprotective efficiency of this drug has been shown in a variety of in vitro as well as in vivo experiments (5-10). In clinical safety studies severe drug related side-effects could be excluded (11). Phase III trials have provided different results. Whereas Grotta described a neuroprotective effect of lubeluzole in patients suffering from acute ischemic stroke (12), this finding could not be confirmed in other trials $(13,14)$.

The present knowledge on the safety profile and efficiency of lubeluzole seems to be promising enough to warrant further studies in immature animals. Recently, we were able to show that lubeluzole does not affect fetal circulatory centralisation during acute asphyxia. This mechanism is of major importance, since it protects the fetal brain from neuronal injury by increasing blood flow to the central organs, i.e. brain, heart, adrenals, when oxygen is in short supply (15). The present study was performed to clarify whether lubeluzole protects the brain of fetal sheep near term from neuronal cell damage. Global cerebral ischemia was induced by occluding both carotid arteries for 30 min. To accoun for drug-related changes in cerebral blood flow that might affect neuronal cell damage we measured cerebral blood flow using the microspheres method.

\section{METHODS}

\section{Animal preparation}

Thirieen fetal sheep were prepared at a mean gestational age of $127 \pm 1$ days (term is at 147 days). All ewes were anesthetized by subarachnoid injection of $8 \mathrm{~mL}$ of $0.75 \%$ (wt/vol) bupivacaine at the lower spine, and were operated under sterile conditions. Polyvinyl catheters were placed in a maternal iliac artery and vein through tibial vessels. The ewe's abdominal wall was opened along the midline and the fetal hindlimbs were exposed through a small uterine incision. Using local anesthesia (prilocaine $\mathrm{HCl} 1.0 \%$ ), polyvinyl catheters were inserted via the pedal vein of each hindlimb into the inferior vena cava. The uterine incision was closed and a second uterine incision was performed over the fetal 
snout. Head and neck of the fetus were exteriorized. To prevent the fetus from breathing, its head was covered by a water-filled rubber glove. Catheters were inserted into the fetal ascending aorta via both brachial arteries. Furthermore, both fetal common carotid arteries were prepared. Cerebral ischemia was induced by occluding the carotid arteries on both sides simuitaneously below the thyroid and above the lingual artery for $30 \mathrm{~min}$ as described recently $(\mathbf{1 6}, 17)$. Thus, blood flow to the cerebrum via anastomoses between the carotid and vertebral arteries was arrested. After cerebral ischemia, a catheter was inserted into the amniotic cavity, and the second intrauterine incision was closed. All catheters were filled with heparin $(1,000 \mathrm{IU} / \mathrm{mL})$, plugged, and passed s.c. to the ewe's flank, where they were exteriorized and protected by a pouch sewn to the skin. On the day of surgery and each day thereafter, the ewe received 2 million units of penicillin G (Grünenthal, Germany) and $80 \mathrm{mg}$ of gentamycin sulfate (Merck, Germany), half i.v. and half into the amniotic cavity.

\section{Experimental Protocol}

After insertion of polyvinyl catheters into the inferior vena cava 6 fetuses received three bolus injections of lubeluzole at $30 \mathrm{~min}$ intervals $(3 \times 0.11 \mathrm{mg} / \mathrm{kg}$ estimated fetal body weight), while an equal volume $(3 \times 1.3 \mathrm{~mL})$ of the solvent was administered to the remaining fetuses. The drugs were donated by Janssen Pharmaceutica, Beerse, Belgium. The concentration of lubeluzole used in the present study was within the same range as that applied in previous investigations. In humans the injected dose ranged from 2.5 to $25 \mathrm{mg} /$ d, i.e. about 0.036 to $0.36 \mathrm{mg} / \mathrm{kg} / \mathrm{d}(12,13,18)$, while in rats lubeluzole was applied at a concentration of between 0.62 and $0.8 \mathrm{mg} / \mathrm{kg}(9,10,19)$. In vitro studies have even shown that lubeluzole has neuroprotective effects down to the pM range (molecular weight: $433,52 \mathrm{~g} / \mathrm{Mol}$ ) (7). In preliminary experiments we applied lubeluzole to fetal sheep by a single i.v. injection at a concentration of $0.33 \mathrm{mg} / \mathrm{kg}$. This resulted in alterations of fetal heart rate as well as arterial hypotension. We therefore considered the dosage applied in the present study to be at the upper limit of the therapeutic range in fetal sheep near term. A further increase in the administered concentration might have altered fetal cardiovascular control and would therefore have interferred with a possible neuroprotective effect of lubeluzole.

Thirty min after the final injection of lubeluzole cerebral ischemia was induced. To determine the time course of changes in fetal cerebral blood flow six batches of differently isotope-labelled microspheres $\left({ }^{1+1} \mathrm{Ce},{ }^{114} \mathrm{In},{ }^{11} \mathrm{Sn},{ }^{103} \mathrm{Ru},{ }^{95} \mathrm{Nb} \&{ }^{46} \mathrm{Sc}, \mathrm{I} 6 \mu \mathrm{m}\right.$ diam., New England Nuclear) were used. The microspheres, suspended in $10 \%$ dextran containing $0.01 \%$ Tween 80 , were sonicated and checked for size, shape and aggregation. Depending 
on the specific activity, $1.2-1.8$ million microspheres per batch were injected into the inferior vena cava before $(-90 \mathrm{~min})$, during $(+3 \mathrm{~min}$ and $+27 \mathrm{~min})$, and after $(+40 \mathrm{~min},+3$ h, and +72 h) 30 min of cerebral ischemia. The number of injected microspheres was large enough to ensure both an adequate number of microspheres per sample and valid blood flow measurements during cerebral ischemia $(20,21)$. Specific calculations revealed that about 400 microspheres were trapped in low flow cerebral areas during ischemia. Thus, for theoretical considerations the blood flow estimates in these areas are within $5 \%$ of the true values (20). During and shortly after injection of the microspheres no significant changes in fetal heart rate or arterial blood pressure were found. Reference blood samples were withdrawn from the brachial artery at a rate of $2.5 \mathrm{~mL} \cdot \mathrm{min}^{-1}$ for $90 \mathrm{~s}(16,17)$. The volume of blood withdrawn was about $22.5 \mathrm{~mL}$ and was simultaneously replaced by maternal blood maintained at $39^{\circ} \mathrm{C}$ in a water bath.

During and shortly after cerebral ischemia fetal heart rate, ascending aortic and intrauterine pressure were recorded simultaneously. After having injected the fourth batch of microspheres (at $+40 \mathrm{~min}$ ) all catheters were closed and secured as described above, the abdominal wall was closed and the ewe was brought back to the metabolic cage, where the fifth injection (at $+3 \mathrm{~h}$ ) was performed. For technical reasons there were no pressure measurements at this point in time. Before each injection, blood samples were obtained from the brachial artery to measure blood gases, oxygen saturation of hemoglobin, and acid-base balance. At the end of the experiment ( $a t+72 \mathrm{~h}$ ) the ewe was given a lethal dose of sodium pentobarbitone and saturated potassium chloride intravenously, while the fetus was perfused with $300 \mathrm{~mL}$ of formalin ( $15 \%$, wt/vol, saline).

The experimental protocols were approved by the appropriate institutional review committee and met the guidelines of the governmental agency responsible.

\section{Measurements}

Ascending aortic and intrauterine pressure, and fetal heart rate were recorded on a polygraph (Hellige, Germany). Blood gases and $\mathrm{pH}$ were measured in an automatic blood gas analyzer (278 Blood Gas. System, Ciba Corning, Frankfurt, Germany), and base excess was calculated. $\mathrm{Hb}$ concentration and oxygen saturation of $\mathrm{Hb}$ were measured photometrically (OSM 2 Hemoximeter, Radiometer, Copenhagen, Denmark) in duplicate.

Fetal cerebral blood flow and the extent of neuronal cell damage were assessed in identical brain specimens. To determine fetal cerebral blood flow using the microspheres method the fetal brain was removed and fixed in formalin for at least 7 days. Afterwards the 
cerebrum was separated from the basal ganglia and divided into four frontal sections (rostral, pericentral, postcentral, occipital) with a thickness of about $1.5 \mathrm{~cm}$. The right and left parts of these four sections were further subdivided into four equal segments (parasagittal $I$ and 2, lateral 1 and 2) each weighing 1 - $2 \mathrm{~g}$. In addition to these 32 cerebral specimens, caudate nucleus, thalamus, hippocampus, tegmentum-colliculi-pons, cerebellum and medulla oblongata were separated. These brain structures were placed in vials, which were filled to the same height to reduce variations in geometry during gamma counting.

After cerebral blood flow analysis the specimens of the fetal brain were removed from the counting vials and embedded in paraffin. Coronal subserial sections of $10 \mu \mathrm{m}$ were obtained and stained with cresylviolet/fuchsin. Every 40 th section was mounted to evaluate the extent of neuronal cell damage. Neuronal cell damage was assessed at a magnification of $250 \mathrm{x}$. Neurons with ischemic celi damage were identified according to the criteria of Brown and Brierley (22). Neuronal cell damage in each microscopical visual field was quantified by the following score: $0-5 \%$ damage (score 1 ), $5-50 \%$ damage (score 2), 50$95 \%$ damage (score 3 ), 95-99 \% damage (score 4 ), and $100 \%$ damage (score 5 ). In the present investigation a scoring system was preferred, since evaluation of neuronal cell loss by neuron counts was unfeasible due to the considerable number of histological sections studied. As assessed by the coefficient of variation the intra- and inter-observer reliability of this procedure was 4 and $10 \%$, respectively (17).

\section{Calculations}

Fetal cerebral blood flow was calculated from counts of the injected nuclide recovered in the fetal cerebrum and the appropriate reference sample, and from the withdrawal rate of the reference sample $(16,17)$. The histological score of each cerebral specimen was calculated by averaging the scores of all visual fields analyzed from three sections of that specimen. The number of visual fields evaluated per specimen ranged between 400 and 500 each. The scores from corresponding specimens from the right and left hemisphere were averaged.

\section{Statistics}

Values are given as means \pm SD. The data were analysed for intra- and intergroup differences by two-way multivariate analysis of variance for repeated measures. The Games-Howell-test was used as a post-hoc testing procedure. 


\section{RESULTS}

The physiological variables of the control and study groups before, during and after 30 min of global cerebral ischemia are shown in Table 1. Before injection of lubeluzole or carrier no significant differences in these variables were found between the control and study groups. At control the plasma concentrations of both glucose and lactate were slightly above the normal range for chronically prepared fetal sheep (23), but had normalized by the end of the experiments.

Table 1. Physiological Variables, Acid-Base Balance, and Blood Gases Before, During and After Transient Global Cerebral Ischemia in Fetal Sheep Near Term

\section{Group Control Ischemia $3^{\circ}$ Ischemia $27^{\circ}$ Recovery $40^{\circ}$ Recovery 3 h Recovery 72 h}

\section{Fetal Heart Rate (beats/min)}

\section{C $\quad 166.3 \pm 15.1 \quad 190.5 \pm 17.0$}

L $\quad 170,8 \pm 23,4 \quad 169,0 \pm 27,6$

$197,8 \pm 31,3$ d $204,3 \pm 33,4 \mathrm{e}$ $202,4 \pm 17,0 \mathrm{~d} 168,0 \pm 20,6 \mathrm{~b}$

n.m.

$159,9 \pm 9.2$

n.m.

$155,7 \pm 19,6$

\section{Mean Arterial Pressure (mmHg)}

\section{C $\quad 51.5 \pm 13.1$}

$67,6 \pm 15,9$ d $60,8 \pm 14,0$

$68,3 \pm 8,7$

$64.0 \pm 6.5$

$$
\begin{aligned}
& 55,6 \pm 11,4 \\
& 54,4 \pm 4,6
\end{aligned}
$$

n.m.

$43,3 \pm 6,0$

L $\quad 55,9 \pm 12,6$

$7,36 \pm 0,03$

$7,33 \pm 0,06$

$7,32 \pm 0,06$

$7,33 \pm 0,06$

$7,37 \pm 0,03$

$7,36 \pm 0,03$

$7,39 \pm 0,02 d$

L $\quad 7,35 \pm 0,04$

$7,35 \pm 0,04$

$7,34 \pm 0,05$

$65,9 \pm 12,2$

$65,2 \pm 9,28$

$67,0 \pm 15,1$

$77.1 \pm 4.0$

$72,7 \pm 7,1$

$71,4 \pm 9,3$

$\begin{array}{ll}\text { C } & 67,7 \pm 9,0 \\ \text { L } & 60,8 \pm 9,4\end{array}$

$60,9 \pm 10,5$

$62,6 \pm 12,5$

$9,3 \pm 2,0$

$9.8 \pm 1.7$

$9,4 \pm 1,4$

$9,1 \pm 1,4$

$10,0 \pm 1,3$

$10,1 \pm 1,7$

$10.9 \pm 1,2$

$8.5 \pm 1,7$

$\begin{array}{ll}\mathrm{C} & 9.6 \pm 1.5 \\ \mathrm{~L} & 9.8 \pm 1.0\end{array}$

$9.9 \pm 1.8$

$0.2 \pm 1,4$

$-1.5 \pm 2,4$

C $\quad 0.2 \pm 1.5$

$1.5 \pm 1,4$

$1,3 \pm 1,4$

$-0,2 \pm 1.6$

$-3,1 \pm 2,5$
$-1,0 \pm 1,7$

$2,6 \pm 1,8$

$1,7 \pm 1,4$

$3,9 \pm 1,3 \mathrm{f}$

Glucose ( $\mathrm{mg} / \mathrm{ml})$

$$
\text { C } \quad 56,7 \pm 17,8 \quad 58,6 \pm 13,4
$$

L $\quad 54,2 \pm 11,7 \quad 57,2 \pm 16,7$

$62,7 \pm 16,4$

$58, I \pm 19,0$

$31,6 \pm 11,6$ e

$60,7 \pm 14,4$

$56,3 \pm 17,2$

$40,8 \pm 15,3$

$18,6 \pm 42$ f

Lactate (mmol/)

\begin{tabular}{lllllllll}
$\mathrm{C}$ & $3,7 \pm 0,9$ & $3,6 \pm 1,0$ & $4,8 \pm 1,7$ & $5,6 \pm 1,8$ & $\mathrm{e}$ & $4,0 \pm 0,9$ & $1,3 \pm 0,2$ & $\mathrm{f}$ \\
$\mathrm{L}$ & $3,1 \pm 1,0$ & $3,2 \pm 0,9$ & $4,2 \pm 0,9$ & $4,8 \pm 1,1$ & $\mathrm{~d}$ & $3,5 \pm 1, \mathrm{I}$ & $1.1 \pm 0,1$ & $\mathrm{e}$ \\
\hline
\end{tabular}

C: untreated fetuses ( $n=7$ ): $L$ : treated fetuses (lubeluzole: $n=6$ ). Values are given as means $\pm S D$ Significant differences between groups are indicated by: $a: p<0.05: b: p<0.0$ I: $c: p<0.001$ and within groups vs time point 'control by d: $p<0.05:$ e: $p<0.01$ : f: $p<0.001$

R.m. = not measured 
Neuronal cell damage was most pronounced in the parasagittal regions, whereas in the more lateral part of the cortex only minor neuronal damage could be seen (Table 3 ). Furthermore, cell damage was observed in the cerebellum, hippocampus and caudate nucleus (Table 4). There were almost no significant differences in neuronal cell damage in any parts of the cerebrum or deeper brain structures between treated and untreated fetuses (Tables 3 and 4).

Table 2. Blood Flow to Various Brain Areas Before, During and After Transient Global Cerebral Ischemia in Fetal Sheep Near Term

\section{Organ Blood Flows $(\mathrm{ml} / \mathrm{min} / 1(\mathrm{M}) \mathrm{g})$}

\begin{tabular}{|c|c|c|c|c|c|c|c|c|c|c|}
\hline Group & Control & Ischemia 3 & & Ischemia $27^{\circ}$ & & Recovery $40^{\circ}$ & & Recovery $3 \mathrm{~h}$ & Recovery $72 \mathrm{~h}$ & \\
\hline \multicolumn{11}{|c|}{ Brain total } \\
\hline C & $141,1 \pm 35,7$ & $23,6 \pm 11.4$ & $f$ & $34,8 \pm 13,5$ & $\mathrm{f}$ & $309.5 \pm 77.8$ & f & $106.7 \pm 25.2$ & $227,0 \pm 45.7$ & f \\
\hline 1. & $144,3 \pm 46,3$ & $15,0 \pm 11,0$ & f & $25,8 \pm 8,4$ & f & $267,7 \pm 68,4$ & f & $102.4 \pm 33,3$ & $233.1 \pm 66.7$ & f \\
\hline \multicolumn{11}{|c|}{ Cerebrum } \\
\hline C & $100,2 \pm 24,7$ & $15.7 \pm 7.8$ & $f$ & $22,3 \pm 11,0$ & $\bar{t}$ & $217,0 \pm 65,6$ & I & $72,1 \pm 16,6$ & $160.9 \pm 34.9$ & c \\
\hline L & $102,9 \pm 34,1$ & $8.6 \pm 7.4$ & f & $16.7 \pm 6.5$ & $f$ & $198,6 \pm 62,2$ & i & $71,6 \pm 24,6$ & $163,8 \pm 51,2$ & $c$ \\
\hline \multicolumn{11}{|c|}{ Cerebellum } \\
\hline C & $151,2 \pm 64,4$ & $27.1 \pm 19.6$ & $\varepsilon$ & $49.7 \pm 22.6$ & e & $413,6 \pm 146,8$ & f & $163.8 \pm 67,6$ & $261.3 \pm 85,6$ & c \\
\hline 1 & $156,4 \pm 56,7$ & $19,2 \pm 16,1$ & f & $38,0 \pm 10.3$ & e & $335.7 \pm 67.1$ & af & $131.4=30.3$ & $261.1 \pm 84.2$ & $d$ \\
\hline \multicolumn{11}{|c|}{ Hippocampus } \\
\hline C & $9 ! .7 \pm 18.3$ & $21,9 \pm 15,7$ & f & $33.8 \pm 16.0$ & e & $233.9 \pm 87.0$ & f & $66.9 \pm 13,6$ & $162.8 \pm 39.2$ & f \\
\hline 1 & $101,1 \pm 31,6$ & $15.9 \pm 13,5$ & $\mathrm{f}$ & $27.2 \pm 16.5$ & $\mathrm{f}$ & $177.7 \pm 36.8$ & b.f & $70.8 \pm 28,6$ & $168.0 \pm 43.1$ & c \\
\hline \multicolumn{11}{|c|}{ Caudate nucleus } \\
\hline $\mathrm{c}$ & $120.8 \pm 33.9$ & $33,4 \pm 27,2$ & e & $37,7 \pm 15,0$ & e & $264.9 \pm 89.0$ & f & $94.2 \pm 32.0$ & $198.6 \pm 90.1$ & c \\
\hline 1 & $116.2 \pm 32.4$ & $8.9 \pm 4.1$ & f & $27.1 \pm 9.3$ & e & $217,2 \pm 67.8$ & f & $90.2 \pm 33,0$ & $194,9 \pm 63.2$ & e \\
\hline \multicolumn{11}{|c|}{ Medula oblongata } \\
\hline C & $201,4 \pm 56.3$ & $61.4 \pm 28.2$ & i & $67.8 \pm 30.8$ & $\mathrm{c}$ & $254,4 \pm 145,5$ & & $199,7 \pm 73,7$ & $354.2 \pm 82.8$ & f \\
\hline L & $196,5 \pm 69.0$ & $37,4 \pm 21,6$ & f & $5 I, 8=14,6$ & $s$ & $234.6 \pm 122.5$ & & $147,9 \pm 41,0$ & $312 . ! \pm 79,2$ & e \\
\hline
\end{tabular}

C: untreated fetuses $(\mathrm{n}=7$ ); $\mathbf{L}$ : treated fetuses (Lubeluzole; $\mathrm{n}=6$ ); Values are given as means \pm SD.

Significant differences between groups are indicated by:

a: $p<0.05: b: p<0.01: c: p<0.001$ and within groups vs time point 'control' by d': $p<0.05 ; \mathrm{e}: \mathrm{p}<0.01: \mathrm{f}: \mathrm{p}<0.001$ 
Table 3. Neuronal Cell Damage in the Cerebrum of Fetal Sheep Near Term $72 \mathrm{~h}$ after Global Cerebral Ischemia

\section{Segments \\ Parasagittal

$1212=$

$\begin{array}{lllllll}\text { Frontal } & \mathrm{C} & 1,73 \pm 0,61 & 1,49 \pm 0.53 & 1,55 \pm 0.69 & 1,71 \pm 0,82 \\ & \mathrm{~L} & 1,72 \pm 0,63 & 1,68 \pm 0,67 & 1,72 \pm 0,69 & 1,75 \pm 0,71\end{array}$

$\begin{array}{rllllll}\text { Pericentral C } & 2,49 \pm 0.97 & 1.93 \pm 0.70 & 1,58 \pm 0.89 * & 1,16 \pm 0.38 * \\ \text { L } & 2,38 \pm 1,01 & 2,10 \pm 1,07 & 1,64 \pm 0.59 & 1,42 \pm 0,47 *\end{array}$

Postcentral C $\quad 2,74 \pm 1,20 \quad 2,34 \pm 1,01 \quad 1,79 \pm 0,71 \| \quad 1,16 \pm 0.35$ "nt

Occipital C $\quad 2,18 \pm 1,35 \quad 2,33 \pm 1,36 \quad 2,17 \pm 1,24 \quad 1,94 \pm 1,13$

L. $\quad 2,06 \pm 0,84 \quad 2,13 \pm 0,85 \quad 2,07 \pm 0,82 \quad 1,88 \pm 0,75$

C: untreated fetuses ( $n=7$ ); L: treated fetuses (lubeluzole; $n=6$ ) Values are given as means $\pm S D$.

" $=\mathrm{P} \leq 0,05 ; * *=\mathrm{P} \leq 0,01$ vs. Parasagittal segment I - Perizentral

$\#=P \leq 0.05: \# \#=P \leq 0.01$ vs. Parasagittal segment $1-$ Postzentral

Table 4. Neuronal Cell Damage in Various Areas of the Diencephaton, Mesencephalon and Brain Stem in Fetal Sheep Near Term 72 Hours After 30 Min of Global Cerebral Ischemia

\begin{tabular}{lll}
\hline Cerebellum & C & $1,41 \pm 0,42$ \\
Hippocampus & L & $1,65 \pm 0,40$ \\
& C & $1,71 \pm 0,71$ \\
Caudate nucleus & L & $2,22 \pm 0,57$ \\
& C & $1,10 \pm 0,11$ \\
Medulla & L & $1,21 \pm 0,15$ \\
& C & $1,00 \pm 0,00$ \\
& L & $1,00 \pm 0,00$ \\
\hline
\end{tabular}

C: untreated feruses ( $\mathrm{n}=7$ ): L: treated feruses (iubeluzole; $n=6$ )

Values are given as means \pm SD. Significant differences between groups could not be detected.

\section{DISCUSSION}

Lubeluzole, the S-isomer of a novel 3,4-difluoro benzothiazole, has been shown to reduce ischemic neuronal cell damage in a variety of in vitro as well as in vivo studies. The neuroprotective property of lubeluzole may result from various effects on neuronal tissue. 
First, lubeluzole has been shown to block ischemia-induced increases in extracellular levels of glutamate and may therefore reduce excitotoxic cell injury (24). Second, lubeluzole inhibits glutamate-stimulated nitric oxide production (25). Nitric oxide combines with superoxide anions to synthesize peroxynitrite, a compound that spontaneously decomposes to form hydroxyl radicals, nitrogen dioxide and $\mathrm{NO}^{2 *}$. All these radicals are able to destroy cell membranes and various intracellular structures. Third, lubeluzole has been shown to activate voltage-sensitive $\mathrm{Ca}^{2+}$ channels in isolated rat dorsal root ganglion cells thus possibly reducing the tremendous intracellular influx of this ion during an ischemic insult (26). This so-called calcium overload leads to cell damage by activating proteases, lipases and endonucleases (27). Fourth, lubeluzole decreased DNA fragmentation and annexin- $\mathrm{V}$ binding in primary hippocampal neurons $(28,29)$. Since these two phenomena are specific markers of apoptosis, lubeluzole might protect neurons from ischemic injury through its inhibitory effects on pathophysiological pathways that trigger the cellular suicide programme. However, these last three lubeluzole-mediated effects have so far only been observed in neuronal tissue in vitro. Their in vivo significance has still to be confirmed

Unfortunately, in the present study we were unable to show any neuroprotective effect of lubeluzole on neuronal cell damage in fetal sheep near term after global ischemia. This appears to be inconsistent with various investigations on adult animals (5-10). However, in almost all of these studies models of focal cerebral ischemia were used (5-9). This type of cerebral ischemia is characterized by an ischemic core and a peri-infarct region known as ischemic penumbra $(30,31)$. In this area, brain tissue is perfused at a level between the thresholds of functional impairment and of morphological integrity. Unless cerebral blood. flow is rapidly improved in this region within a few hours after the insult, neuronal cell damage is the inevitable result $(30,31)$. As shown in previous studies, glutamate is released in tremendous amounts from the infarct core into the extracellular space after focal ischemia. Increases of up to 80 limes above baseline levels have been observed (32). The released glutamate activates the neuronal NO-synthase via calcium influx through NMDAregulated calcium channels $(33,34)$. In focal ischemia this pathway may be of greater importance for the development of neuronal cell damage than in global ischemia, since in the latter type of ischemia only a moderate and short-lasting increase in glutamate release has been observed $(35,36)$. This may explain in part the differences in neuronal outcome between the present study and previous investigations after treatment of brain injury by lubeluzole. In addition, many other pathophysiological mechanisms such as inhibition of protein synthesis, generation of epileptogenic impulses etc are differently regulated in focal and global ischemia and may therefore alter the neuroprotective efficiency of lubeluzole $(37-41)$. 
However, there is one study in adult rats indicating that lubeluzole protects the brain from neuronal cell loss after global ischemia (10). Posttreatment with lubeluzole significantly increased the number of viable neurons in the hippocampus. There could be a number of reasons for the difference in neuronal outcome between this study and our experiments. First, the postischemic pattern of pathophysiological changes in the immature brain may not be the same as in the adult. For example, glutamate release has been reported to be significantly lower in neonates than in adults (42). Although glutamate toxicity has been reported in fetal sheep after cerebral ischemia, this may also affect the induction of NOsynthase via NMDA-receptor regaluted calcium channels. Since the neuroprotective properties of lubeluzole are mediated in part by its effects on the NO-system (25), this may explain the differences in neuronal outcome between the present study and that of Haseldonckx (10). Furthermore, inhibition of the NO-synthase in the fetal sheep had no influence on neuronal cell damage, indicating that NO release may not play a major pathophysiological role in the development of brain injury under these conditions (43). Second, in our study lubeluzole was injected before cerebral ischemia, whereas Haseldonckx and co-workers applied the drug shortly after the insult (10). One might therefore speculate that bolus injection of lubeluzole before ischemia results in an insuffiencient drug supply during the postischemic period. However, as demonstrated in patients with acute ischemic stroke, the mean terminal half-life of this compound in the plasma is $27.7 \mathrm{~h} \mathrm{(18)}$. Thus, application of lubeluzole one hour before ischemia guarantees postischemic plasma concentrations that are within the therapeutic range. When designing the present study a pretreatment protocol was chosen, since we considered this to be more effective than a posttreatment strategy. Especially under clinical conditions, pretreatment of babies at risk of hypoxic-ischemic encephalopathy by maternal application of various neuroprotective drugs would seem conceivable. Whether an additional application of lubeluzole after cerebral ischemia provides neuroprotection in the present experimental model, will have to be examined in further investigations. Third, the endpoint in our study and that of Haseldonckx and co-workers was different. Whereas neuronal cell damage was. evaluated only 3 days after the insult in the present investigation, it was not assessed until 7 days after cerebral ischemia in the latter study. Unfortunately, the sheep model does not allow for longer postischemic observation periods, since this would result in a tremendous increase in the abortion rate due to intrauterine infection and fetal distress. It is conceivable that even several days after the ischemic insult the continued activation of the inducible form of NO-synthase in astrocytes and microglia might result in an increased production of NO (44). One might therefore object that delayed neuronal cell death due to an increased NO production cannot be evaluated using this model (45-47). Since modulation of NO toxicity is a probable target for lubeluzole (25), the negative result of the present study might be due to this phenomenon. This objection cannot be fully excluded. However, as 
mentioned above NO toxicity may not play any major part in the development of neuronal cell death in this model, since inhibition of the NO system had no effect on brain injury (43). Furthermore, as shown in a recent study using the MRI-technique, neuroprotective effects of lubeluzole can already be observed within a few hours after ischemia (9). If the main target of lubeluzole is NO toxicity, then a neuroprotective effect should have been observed as early as 3 days after ischemia as demonstrated in a recent study on neonatal rats using an inhibitor of the NO-synthase (48). To exclude very delayed neuroprotective effects of lubeluzole on the neuropathologic outcome in immature animals additional experiments will have to be performed using other ischemic models, e.g. unilateral carotid occlusion in the neonatal rat $(49,50)$. However, it should be taken into account that drugrelated side effects of various neuroprotective substances, such as lubeluzole, on the cardiovascular system cannot be monitored in such small animals. We therefore feel that in a first approach the present model was highly appropriate for investigation of the neuroprotective efficacy of lubeluzole.

As already shown for a variety of other drugs (for review: 40), the neuroprotective properties of lubeluzole might depend on the type of ischemia studied and the animal model used. It is therefore conceivable that lubeluzole might protect the fetall brain from ischemic insults in animal models of systemic asphyxia induced by occlusion of the umbilical cord or the uterine arteries. Neuronal loss has been observed after repetitive cord occlusion in the striatum, an area with high glutaminergic input (51). Since lubeluzole is known to inhibit glutamate release during an ischemic insult (24), this drug may be neuroprotecive in such an animal model. However, when brain injury is induced by systemic asphyxia the extent and location of neuronal cell loss often vary widely (52-54) and there is a considerable rise in the fetal abortion rate. Since hardly any neuroprotective effect can be demonstrated under such conditions, we preferred the fetal sheep model of global cerebral ischemia caused by occlusion of both carotid arteries. The fact that lubeluzole did not appear to have any neuroprotective effect in the present model cannot be attributed to a lack of glutamate toxicity. As already shown in a previous study the application of MK-801 after global cerebral ischemia caused a significant improvement in neuropathological outcome in fetal sheep (55).

From the present results, we conclude that pretreatment with lubeluzole fails to protect the brain of fetal sheep near term from injury after transient global cerebral ischemia. However, since the observation period lasted only 3 days, a possible effect of lubeluzole on pathophysiological mechanisms inducing delayed neuronal cell death can not be fully excluded. 


\section{ACKNOWLEDGEMENT}

The excellent technical assistance of Otmar Adam. Dorothea Ehler and Monika Nickel is gratefully acknowledged. This work was supported by Deutsche Forschungsgemeinschaft and by Janssen Pharmaceutica (Beerse, Belgium).

\section{REFERENCES}

1. Volpe JJ 1995 Neurology of the Newborn. Saunders, Philadelphia

2. Wangen K, Myhrer T, Moldstad JN, Iversen EG, Fonnum F 1997 Modulatory treatment of NMDA receptors in neonatal rats affects cognitive behavior in adult age. Brain Res Dev Brain Res 99:126-30

3. Green LR, Bennet L, Hanson MA 1996 The role of nitric oxide synthesis in cardiovascular responses to acute hypoxia in the late gestation sheep fetus. J Physiol $497: 271-7$

4. Gunn AJ, Williams CE, Mallard EC, Tan WKM, Gluckman PD 1994 Flunarazine, a calcium channel antagonist, is partially prophylactically neuroprotective in hypoxic/ischemic encephalopathy in the fetal sheep. Pediatr Res 35:657-63

5. Aranowski J, Strong R, Grotta JC 1996 Combined neuroprotection and reperfusion therapy for stroke. Effect of lubeluzole and diaspirin cross-linked hemoglobin in experimental focal ischemia. Stroke 27:1571-7

6. Buchkremer-Ratzmann I, Witte OW 1997 Pharmacological reduction of electrophysiological diaschisis after photothrombotic ischemia in rat neocortex. Eur J Pharmacol 320:103-9

7. Culmsee C, Junker V, Wolz P, Semkova I, Krieglstein J 1998 Lubeluzole protects hippocampal neurons from excitotoxicity in vitro and reduces brain damage caused by ischemia. Eur J Pharmacol 342:193-201

8. De Ryck M, Scheller D. Clincke G, Janssen M, Van Reet S 1995 Lubeluzole, a novel benzothiazole, protects neurologic function, reduces infarct size, and blocks periinfarct glutamate rise after cerebral thrombotic stroke in rats. Cerebrovasc Res 5:264

9. De Ryck M, Verhoye M, Van der Linden M 2000 Diffusion-weighted MRI of infarct growth in a rat photochemical stroke model: effect of lubeluzole. Neuropharmacology 39:691-702

I0. Haseldonçkx M. Van Reempts J, Van de Ven M, Wouters L, Borgers M 1997 Protection with lubeluzole against delayed ischemic brain damage in rats. A quantitative histopathologic study. Stroke 28:428-32

11.Diener HC, Hacke W, Hennerici M, Rådberg J, Hantson L, De Keyser J 1996 Lubeluzole in acute ischemic stroke. A double-blind, placebo-controlled Phase II trial. Stroke 27:76-81

12. Grotta J 1997 Lubeluzole treatment of acute ischemic stroke. The US and Canadian Lubeluzole Ischemic. Stroke Group. Stroke 28:2338-46 
13. Diener HC 1998 Multinational randomised controlled trial of lubeluzole in acute ischaemic stroke. European and Australian Lubeluzole Ischaemic Stroke Study Group. Cerebrovasc Dis 8:172-81

14. Diener HC, Cortens M, Ford G, Grotta J, Hacke W, Kaste M, Koudstaal M, Wessel T 2000 Lubeluzole in acute ischemic stroke treatment: a double blind study with an 8 . hour inclusion window comparing a $10-\mathrm{mg}$ daily dose of lubeluzole with placebo. Stroke 31:2543-51

15. Berger R, Garnier Y, Löbbert T, Pfeiffer D, Jensen A 2001 Circulatory responses to acute asphyxia are not affected by the glutamate antagonist lubeluzole in fetal sheep near term. J Soc Gynecol Investig 8:143-8

16. Berger R, Lehmann T, Karcher J, Garnier Y, Jensen A 1998 Low dose flunarizine protects the fetal brain from ischemic injury in sheep. Pediatr Res 44:1-6

17. Berger R, Lehmann T, Karcher J, Schachenmayr W, Jensen A 1996 Relation between cerebral oxygen delivery and neuronal cell damage in fetal sheep near term. Reprod Fertil Dev 8:317-21

18. De Keyser J, van de Velde V, Schellens RLLA, Hantson L, Tritsmans L, Gheuens J, van Peer A, Woestenborghs R, Franke CL, van Gorp J. Safety and pharmacokinetics of the neuroprotective drug lubeluzole in patients with ischemic stroke. Clin Ther 1997 19:1340-51

19. Kroppenstedt SN, Stroop R. Kern M, Thomale UW, Schneider GH, Unterberg AW 1999 Lubeluzole following traumatic brain injury in the rat. J Neurotrauma 16:629-37

20. Buckberg GD, Luck JC, Payne DB, Hoffmann JL, Archie JP, Fixler DE 1971 Some sources of error in measuring regional blood flow with radioactive microspheres. J Appl Physiol 31:598-604

21. Jensen A, Hohmann M, Künzel W 1987 Dynamic changes in organ blood flow and oxygen consumption during acute asphyxia in fetal sheep. J Dev Physiol 9:534-59

22.Brown AW, Brierley JB 1971 Anoxic-ischaemic cell change in rat brain light microscopic and fine structural observations. I Neurol Sci 16:59-84

23. Jensen A, Berger R 1991 Fetal circulatory responses to oxygen lack. I Dev Physiol $16: 181-207$

24. Scheller D. De Ryck M, Kolb J, Szathmary S, Van Reempts J, Clincke B, Tegtmeier F 1997 Lubeluzole blocks increases in extracellular glutamate and taurine in the periinfarct zone in rats. Eur J Pharmacol 338:243-51

25. Lesage AS, Peeters L, Leysen JE 1996 Lubeluzole, a novel long-term neuroprotectant, inhibits the glutamate-activated nitric oxide synthase pathway. J Pharmacol Exp Ther 279:759-66

26. Marannes R, De Prins E 2000 Site of action of lubeluzole on voltage-sensitive $\mathrm{Ca}^{2+}$ channels in isolated dorsal root ganglion cells of the rat: influence of $\mathrm{pH}$. J Pharmacol Exp Ther 295:531-45

27. Siesjö BK, Bengtsson F 1989 Calcium fluxes, calcium antagonists, and calcium-related pathology in brain ischemia, hypoglycemia, and spreading depression: a unifying hypothesis. I Cereb Blood Flow Metab 9:127-40 
28. Maiese K, Vincent AM 2000 Critical temporal modulation of neuronal programmed cell injury. Cell Mol Neurobiol 20:383-400

29. Maiese K, Vincent AM 2000 Membrane asymmetry and DNA degradation: functionally distinct determinants of neuronal programmed cell death. J Neurosci Res 2000 59:568-80

30. Astrup J, Siesjö BK, Symon I 1981 Thresholds in cerebral ischemia: the ischemic penumbra. Stroke 12:723-5

31. Heiss WD, Graf R 1994 The ischemic penumbra. Curr Opin Neurol 7:11-9

32. Hillered L, Hallstrom A, Segersvard S, Persson L, Ungerstedt U 1989 Dynamics of extracellular metabolites in the striatum after middle cerebral artery occlusion in the rat monitored by intracerebral microdialysis. J Cereb Blood Flow Metab 9:607-16

33. East SJ, Garthwaite J 1991 NMDA receptor activation in rat hippocampus induces cGMP formation through the L-arginine-nitric oxide pathway. Neurosci Lett 123:17-9

34. Southam E, East SJ, Garthwaite 1991 Excitatory amino acid receptors coupled to the nitric oxide/cyclic GMP pathway in rat cerebellum during development. J Neurochem 56:2072-81

35. Hagberg H, Andersson P, Kjellmer I, Thiringer K, Thordstein M 1987 Extracellular overflow of glutamate, aspartate, GABA and taurine in the cortex and basal ganglia of fetal lambs during hypoxia-ischemia. Neurosci Lett 78:311-7

36. Tan WK, Williams CE, During MJ, Mallard CE, Gunning MI, Gunn AJ, Gluckman PD 1996 Accumulation of cytotoxins during the development of seizures and edema after hypoxic-ischemic injury in late gestation fetal sheep. Pediatr Res 39:791-7

37. Back T, Kohno K, Hossmann KA 1994 Cortical negative DC deflections following middle cerebral artery occlusion and $\mathrm{KCl}$-induced spreading depression: effect on blood flow, tissue oxygenation, and electroencephalogram. J Cereb Blood Flow Metab $14: 12-9$

38. Back T, Ginsberg MD, Dietrich WD, Watson BD 1996 Induction of spreading depression in the ischemic hemisphere following experimental middle cerebral artery occlusion: effect on infarct morphology. J Cereb Blood Flow Metab !6:202-13

39. Bodsch W, Barbier A, Oehmichen M, Grosse Ophoff B, Hossmann KA 1986 Recovery of monkey brain after prolonged ischemia. II. Protein synthesis and morphological alterations. J Cereb Blood Flow Metab 6:22-33

40. Hossmann K-A 1994 Mechanisms of ischemic injury: is glutamate involved? In: Krieglstein J. Oberpichler-Schwenk H (eds) Pharmacology of Cerebral Ischemia. Wissenschaftliche Verlagsgesellschaft GmbH, Stuttgart, 1994, pp 239-51

41. Mies G, Ishimaru S, Xie Y, Seo K, Hossmann KA 1991 Ischemic thresholds of cerebral protein synthesis and energy state following middle cerebral artery occlusion in rat. J Cereb Blood Flow Metab 1 1:753-61

42. Berger R, Jensen A, Hossmann K-A, Paschen W 1998 Effect of mild hypothermia during and after transient in vitro ischemia on metabolic disturbances in hippocampal slices at different stages of development. Dev Brain Res 105:67-77 
43. Marks KA, Mallard CE, Roberts I, Wililiams CE, Gluckman PD, Edwards AD 1996 Nitric oxide synthase inhibition attenuates delayed vasodilation and increases injury after cerebral ischemia in fetal sheep. Pediatr Res 40:185-91

44. Endoh M, Maiese K, Wagner J 1994 Expression of the inducible form of nitric oxide synthase by reactive astrocytes after Iransient global ischemia. Brain Res 65 I:92-100

45. Kohno K, Ohta S, Kohno K, Kumon Y, Mitani A, Sakaki S, Kataoka K 1996 Nitric oxide synthase inhibitor reduces delayed neuronal death in gerbil hippocampal CAI neurons after transient global ischemia without reduction of brain temperature or extracellular glutamate concentration. Brain Res 738:275-80

46. Lei B, Adachi N, Nagaro T, Arai T, Koehler RC 1999 Nitric oxide production in the CAI field of the gerbil hippocampus after transient forebrain ischemia: effects of 7 . nitroindazole and NG-nitro-L-arginine methyl ester. Stroke 30:669-77

47. Nanri K, Montecot C, Springhetti V, Seylaz J, Pinard E 1998 The selectice inhibitor of neuronal nitrix oxide synthase, 7-nitroindazole, reduces the delayed neuronal damge due to forebrain ischemia in rats. Stroke 29:1248-53

48. Tsuji M, Higuchi Y, Shiraishi K, Kume T, Akaike A, Hattori H 2000 Protective effect of aminoguanidine on hypoxic-ischemic brain damage and temporal profile of brain nitric oxide in neonatal rat. Pediatr Res 47:79-83

49. Levine S 1960 Anoxic-ischemic encephalopathy in rats. Am J Pathol 36:1-17

50. Rice JE, Vanucci RC, Brierley JB 1981 The influence of immaturity on hypoxicischemic brain damage in the rat. Am Neurol 9:131-41

51. Mallard EC. Waldvogel HJ, Williams CE, Faull RLM, Gluckman PD 1995 Repeated asphyxia causes loss of striatal projection neurons in the fetal sheep brain. Neuroscience 65:827-36

52. de Haan HH, Van Reempts JL, Vles JS, de Haan J, Hasaart TH 1993 Effects of asphyxia on the fetal lamb brain. Am J Obstet Gynecol 169:1493-501

53. Ikeda T, Murata Y, Quilligan EJ, Parer JT, Murayama T, Koono M 2000 Histologic and biochemical study of the brain, heart, kidney, and liver in asphyxia caused by occlusion of the umbilical cord in near-term fetal lambs. Am J Obstet Gyneco! $182: 449-57$

54. Penning DH, Grafe MR, Hammond R, Matsuda Y, Patrick J, Richardson B 1994 Neuropathology of the near-term and midgestation ovine fetal brain after sustained in utero hypoxemia. Am J Obstet Gynecol 170:1425-32

55. Tan WKM, Williams CE, Gunn AJ, Mallard CE, Gluckman PD 1992 Suppression of postischemic epileptiform activity with MK-801 improves neural outcome in fetal sheep. Ann Neurol 32:677-82 


\section{Chapter 8}

\section{NEUROPROTECTIVE EFFECTS OF MAGNESIUM ON METABOLIC DISTURBANCES IN FETAL HIPPOCAMPAL SLICES AFTER OXYGEN-GLUCOSE DEPRIVATION: MEDIATION BY NITRIC OXIDE SYSTEM}

Garnier Y, Middelanis J, Jensen A, Berger R

Journal of the Society for Gynecologic Investigation, 2002;9:86-92 


\section{ABSTRACT}

The aim of the present study was to investigate the effects of magnesium on metabolic disturbances in hippocampa! slices prepared from fetal guinea pigs after oxygen-glucose deprivation (OGD). Metabolic disturbances were assessed by measuring changes in energy metabolism and protein synthesis. In addition we determined cGMP concentrations in the slices after OGD, as a measure of nitric oxide (NO) production, to clarify whether a possible neuprotective effect of magnesium is mediated in part through the NO-system. Tweive hours after oxygen-glucose deprivation ATP concentration and protein synthesis in the hippocampal slices were significantly reduced depending on the severity of OGD. Increasing magnesium concentration in the incubation medium from $1.3 \mathrm{mM}$ to $3.9 \mathrm{mM} 2$ h before OGD significantly improved the recovery of ATP and protein synthesis, whereas Ireatment after OGD was ineffective. cGMP concentrations rose dramatically in hippocampal slices $10 \mathrm{~min}$ after OGD indicating a significant increase in NO-production. When the concentration of magnesium in the aCSF was increased $2 \mathrm{~h}$ before OGD the rise in tissue levels of cGMP was considerably reduced. Again, treatment after OGD had no effect. From the present study we conclude that increasing magnesium concentration in the aCSF before OGD alleviates metabolic disturbances in hippocampal slices from mature fetal guinea pigs, whereas treatment after OGD has no effect. This neuroprotective property of magnesium may be mediated in part through the inhibition of NO-production shortly after OGD. 


\section{INTRODUCTION}

Children undergoing hypoxic-ischemic brain damage during birth often suffer from the drastic consequences of this misfortune for the rest of their lives (1). Despite the many farreaching consequences of this kind of perinatal insult, the range of effective therapeutic measures available is limited (2). In addition, many so-called neuroprotective drugs such as glutamate antagonists cannot be applied during the perinatal period owing to sideeffects on the developing brain (3). The retrospective analysis by Nelson and Grether showing that magnesium, a well-known tocolytic agent, also has neuroprotective properties was therefore very encouraging. In fact, the incidence of cerebral palsy in newborns weighing less than $1500 \mathrm{~g}$ was significantly lower, if the mother received magnesium before birth $(4,5)$. Unfortunately, a subsequent study of the same research group could not confirm the neuroprotective efficacy of magnesium (6). The authors attributed this to changes in medical practice between the two observation periods. Furthermore, experimental studies with differing perinatal animal models have also yielded inconclusive results with regard to magnesium neuroprotection. Both protective (7-15) and non-protective effects $(14,16,17)$ have been reported with different timing of administration at different stages of development. As recently proposed, the neuroprotective inefficacy of magnesium, especially when applied after cerebral ischemia, may be caused by its hypotensive effects, since magnesium, as a calcium antagonist has vasodilatory properties (14). Furthermore, the pathophysiological mechanisms through which a possible neuroprotective effect of magnesium could be mediated are not well understood. One pathway may be the NO-system. NO is a free radical synthesized by NOsynthase (NOS) in neurons and other cell types in response to rises in levels of intracellular calcium during and after ischemia. During reperfusion, $\mathrm{NO}$ and superoxide radicals combine to produce peroxynitrite, leading to the formation of more potent radicals. Destruction of cerebral tissue is the inevitable result (18). Since magnesium has been reported to block cerebral NMDA-receptors which themselves control calcium channels (13), the neuroprotective effect of magnesium may be mediated through an inhibition of NO-production after ischemia brought about by a reduction of neuronal calcium influx.

The aim of the present study was therefore to investigate the effects of magnesium on metabolic disturbances in fetal brain during and after ischemia, while excluding its effects on the cardiovascular system. For this purpose we used the in vitro system of oxygenglucose deprivation (GGD) in hippocampal slices prepared from mature guinea pig fetuses. Metabolic disturbances were assessed by measuring changes in energy metabolism and protein synthesis. In addition we determined cGMP concentrations in the slices after OGD, as a measure of NO-production, to clarify whether a possible neuprotective effect of magnesium is mediated in part through the NO-system $(19,20)$. 


\section{METHODS}

The present study was performed on guinea pigs at 0.9 gestation (term is at 68 days). The dams were anesthetized with halothane and 34 fetuses were delivered by Caesarean section. The fetal hippocampi were dissected out and cut into $500 \mu \mathrm{m}$ thick, transverse slices. The tissue slices were transferred to an incubation chamber, containing artificial cerebrospinal fluid (standard-aCSF). To prevent bacterial contamination $10 \mathrm{mg} / \mathrm{L}$ each of streptomycin and erythromycin were added to the aCSF. Additionally, aCSF was filtered (pore diameter 0.1 m) into sterilized containers, and $\mathrm{CuSO}_{4}$ was added to the incubation chamber reservoir. aCSF was pumped through the incubation chamber at a rate of $1 \mathrm{ml} /$ $\min (21,22)$. The aCSF was equilibrated with a gas mixture of oxygen and carbon dioxide $\left(95 \% \mathrm{O}_{2} / 5 \% \mathrm{CO}_{2}\right)$, and the incubation temperature was held at $37^{\circ} \mathrm{C}$. To allow recovery from preparation stress the slices were incubated in standard aCSF for $90 \mathrm{~min}$. The magnesium concentration of the aCSF in the study groups was increased from $1.3 \mathrm{mM}$ to $3.9 \mathrm{mM}$ either at the end of this initial recovery period or immediately after OGD. Ninety minutes after the initial recovery period the glucose concentration of the standard aCSF was lowered from $10 \mathrm{mM}$ to $2 \mathrm{mM}$ for $30 \mathrm{~min}$ to accelerate the breakdown of high-energy phosphates in the tissue slices during exposure to OGD $(19,21)$.

The experimental protocol included a $210 \mathrm{~min}$ preincubation phase $1180 \mathrm{~min}$ in $10 \mathrm{mM}$ glucose and $30 \mathrm{~min}$ in $2 \mathrm{mM}$ glucose aCSF), an ischemic phase $(10-40 \mathrm{~min})$ and a recovery phase (12 h starting from the end of OGD). A separate incubation chamber. equilibrated with $95 \% \mathrm{~N}_{2} / 5 \% \mathrm{CO}_{2}$, was used for the induction of OGD. In contrast to the standard aCSF, the ischemic aCSF contained no glucose or HEPES. HEPES was omitted, because its buffering capacity may influence the fall in $\mathrm{pH}$ accompanying OGD. Before the tissue slices were transferred to the anoxic incubation chamber, they were washed in aglycemic aCSF in order to lower the glucose levels in the tissue still further. During OGD the tissue slices were completely submerged in the aCSF. No additional aCSF was pumped through the chamber during this period (flow rate: $0 \mathrm{ml} / \mathrm{min}$ ). In the postischemic phase the tissue slices were transferred back to standard aCSF (flow rate: $1 \mathrm{ml} / \mathrm{min}$ ) and equilibrated with carbogen $\left(95 \% \mathrm{O}_{2} / 5 \% \mathrm{CO}_{2}\right)$. After a recovery period of $12 \mathrm{~h}$ the slices were sampled to measure the tissue concentrations of adenine nucleotides and protein synthesis.

In a second set of experiments we investigated whether a possible neuroprotective effect of magnesium might be mediated in part through the NO-system. Here we determined the tissue concentrations of CGMP 10 min after an OGD-period of between 10 and 40 min using a RIA (NEN, Bad Homburg. Germany). For these measurements tissue slices were frozen in liquid nitrogen and extracted with perchloric acid. As in the first set of 
experiments, the magnesium concentration in the incubation medium of the study groups was raised from $1.3 \mathrm{mM}$ to $3.9 \mathrm{mM}$ either $2 \mathrm{~h}$ before or immediately after OGD. To confirm that elevated tissue concentrations of cGMP really reflect increased NOproduction, we inhibited NO-synthase with the specific blocker N-nitro-L-arginine (LNNA). L-NNA $(100 \mu \mathrm{M})$ was added to the incubation medium 30 min prior to, during and $10 \mathrm{~min}$ after OGD. By these measures the increase of cGMP tissue concentration 10 min after OGD could be completely suppressed. This observation confirms previous studies showing the same effect $(19,20)$.

To determine the tissue concentrations of adenine nucleotides the slices were frozen in liquid nitrogen. ATP, ADP and AMP were measured by high pressure liquid chromatography (HPLC) after extraction with perchloric acid (21). The adenylate energy charge (AEC), a measure of the relation of energy consumption to energy production, was estimated from the following formula: $\mathrm{AEC}=([\mathrm{ATP}]+0.5[\mathrm{ADP}]) /([\mathrm{ATP}]+[\mathrm{ADP}]+$ [AMP]) (23). The protein content of the tissue slices was measured by the Lowry method (24).

Protein synthesis was assessed from the incorporation rate of ${ }^{14} \mathrm{C}$-leucine into tissue proteins. After $30 \mathrm{~min}$ of incubation in standard aCSF, to which $5 \mu \mathrm{Ci} / \mathrm{mL} \mathrm{L}-\left[1-{ }^{14} \mathrm{C}\right]$ leucine (Amersham Buchler, Braunschweig, Germany; specific activity $54 \mathrm{mCi} / \mathrm{mMol}$ ) had been added, the tissue slices were homogenized in trichloroacetic acid (TCA). The radioactivity of the TCA-precipitated material was then measured by liquid scintillation counting $(21,25)$.

All data are given as means \pm SD. The statistical significance of differences between groups was assessed by a two-way analysis of variance (ANOVA), followed by the Scheffé post-hoc test. There were no repeat studies in a single preparation and no data was discarded. The experimental protocols were approved by the appropriate institutional review committee and met the guidelines of the governmental agency responsible.

\section{RESULTS}

The concentrations of ATP measured in hippocampal slices from mature guinea pig fetuses are shown in Fig. I as percentages of the control values. The ATP tissue levels in the two untreated control groups averaged $20.3 \pm 2.3$ and $21.2 \pm 2.4 \mu \mathrm{mol} / \mathrm{mg}$ protein, 
respectively. At the end of the recovery period, ATP concentration in the hippocampal slices was significantly reduced depending on the length of OGD. The tissue content of
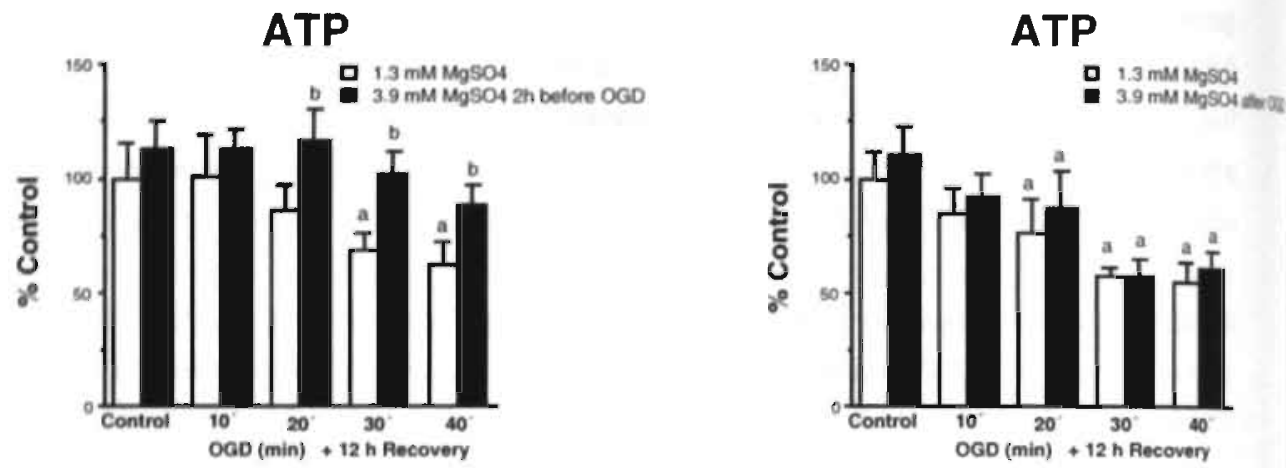

Figure I. ATP tissue concentration (\% of control) in hippocampal slices of mature guinea pig fetuses $12 \mathrm{~h}$ after oxygen-glucose deprivation (OGD). OGD lasted between 10 and $40 \mathrm{~min}$. The ATP tissue levels in the two untreated control groups (open bars) averaged $20.3 \pm 2.3$ and $21.2 \pm 2.4 \mu \mathrm{mol} / \mathrm{mg}$ protein. respectively. Magnesium concentration in the aCSF of the study groups was increased from $1.3 \mathrm{mM}$ to $3.9 \mathrm{mM}$ either $2 \mathrm{~h}$ before or immediately after OGD. Values are given as means \pm SD. Each group comprised 5 slices. Intraand intergroup differences were measured by a two-way analysis of variance followed by Scheffe- $F$-test $a: P$ $<0.05$ OGD vs. Control: $\mathrm{b}$ : $\mathrm{P}<0.05 \mathrm{MgSO}_{4}$ vs. Control).
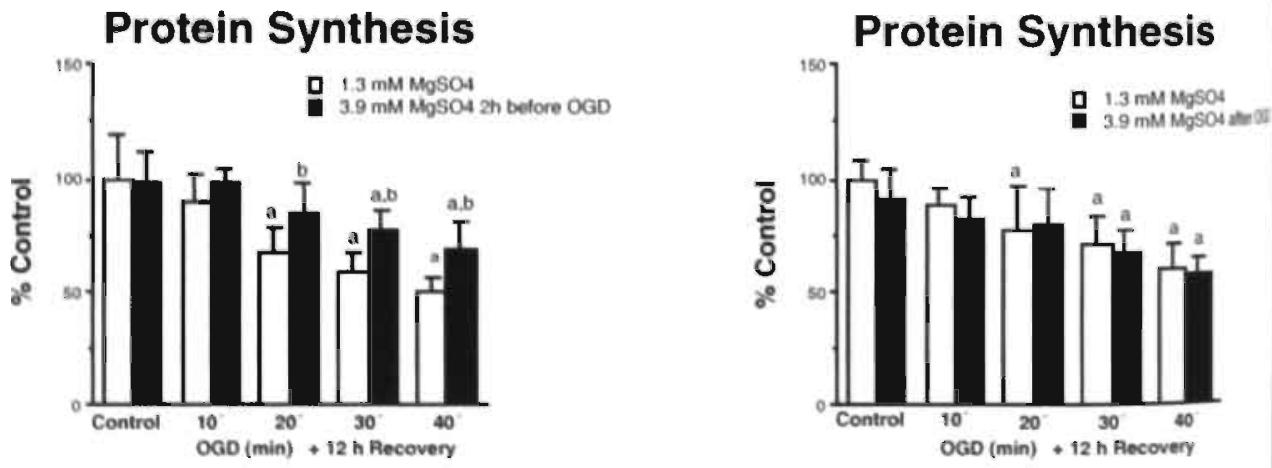

Figure 2. Protein synthesis rate (PSR) ( $\%$ of control) in hippocampal slices of mature guinea pig fetuses $12 \mathrm{~h}$ after oxygen-glucose deprivation (OGD). OGD lasted between 10 and $40 \mathrm{~min}$. PSR in the two untreated control groups (open bars) averaged $124 \pm 23$ and $125 \pm 11 \mathrm{dpm} / 30 \mathrm{~min}$. $\mu \mathrm{g}$ protein. respectively. Magnesium concentration in the aCSF of the study groups was increased from $1.3 \mathrm{mM}$ to $3.9 \mathrm{mM}$ either $2 \mathrm{~h}$ before or immediately after OGD. Values are given as means \pm SD. Each group comprised 5 slices. Intraand intergroup differences were measured by a two-way analysis of variance followed by Scheffe-F-test ia: P $<0.05$ OGD vs, Control; b: $\mathrm{P}<0.05 \mathrm{MgSO}_{4}$ vs. Control). 
adenylates together with the adenylate energy charge in hippocampal slices are given in Table 1. Total adenylate pool in the two untreated control groups averaged $22.4 \pm 2.9$ and $23.8 \pm 2.5 \mu \mathrm{mol} / \mathrm{mg}$ protein and the adenylate energy charge $0.92 \pm 0.03$ and $0.93 \pm 0.02$, respectively.

The changes in total adenylate pool after OGD closely resembled those in ATP concentrations (Table 1). Adenylate energy charge scarcely differed at all from control values at the end of the recovery period. Fig. 2 illustrates PSR in hippocampal slices measured as incorporation of ${ }^{14} \mathrm{C}$-leucine into tissue proteins. PSR in the two untreated control groups averaged $124 \pm 23$ and. $125 \pm 11 \mathrm{dpm} / 30 \mathrm{~min} / \mu \mathrm{g}$ protein, respectively. Like energy metabolism, PSR was severely disturbed by OGD depending on the length of the insult. Increasing magnesium concentration in the aCSF $2 \mathrm{~h}$ before OGD significantly improved the recovery of energy metabolism and protein synthesis, whereas treatment after OGD was ineffective.

The cGMP concentrations significantly increased in hippocampal slices 10 min after OGD lasting 10 to $40 \mathrm{~min}$. This rise could be completely suppressed by blocking NO synthase with the specific blocker N-nitro-L-arginine (L-NNA) (Fig. 3). When the magnesium concentration in the aCSF was increased $2 \mathrm{~h}$ before OGD the rise in tissue levels of cGMP was considerably reduced. Again, treatment after OGD had no effect (Fig. 4).

\section{Inhibition of NO-Synthase}

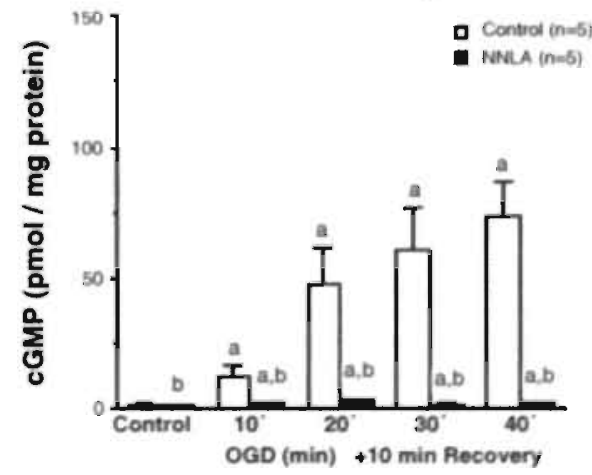

Figure 3 Concentration of cGMP in hippocampal tissue slices after different periods of OGD (10 - 40 min) and a recovery phase of $10 \mathrm{~min}$. NO-synthase was inhibited by incubating slices in $100 \mu \mathrm{M} \mathrm{L}-\mathrm{NNA}$. The cGMP concentration in the slices of the control group (open bar) was $1.47 \pm 0.52 \mathrm{pmol} / \mathrm{mg}$ protein. Values are given as means \pm SD. Each group comprised 5 slices. Intra- and intergroup differences were measured by a two-way analysis of variance followed by Scheffe-F-test (a: $\mathrm{P}<0.05$ OGD vs. Control; $b: \mathrm{P}<0.05 \mathrm{~L}-\mathrm{NNA}$ vs. Control). 

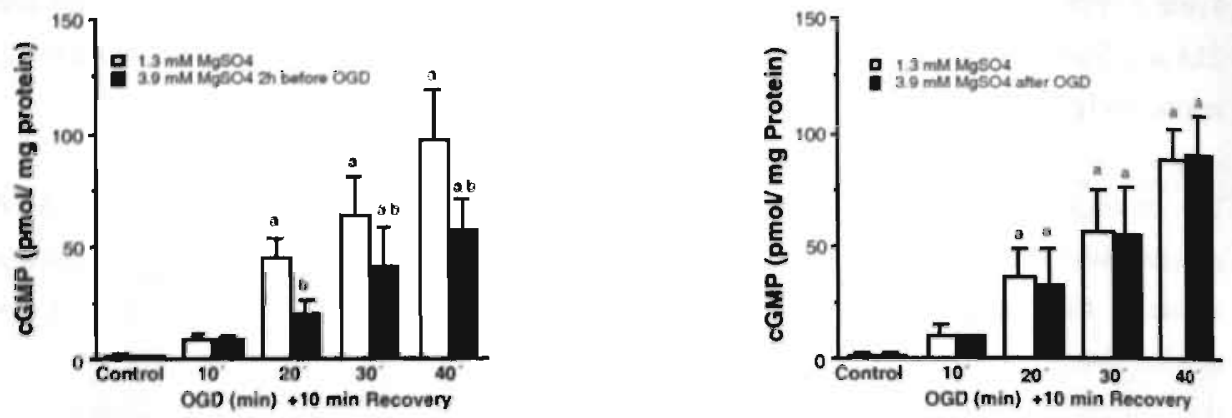

Flgure 4. Concentration of cGMP in hippocampal slices of mature guinea pig fetuses $10 \mathrm{~min}$ after oxygenglucose deprivation (OGD). OGD lasted between 10 and $40 \mathrm{~min}$. The cGMP concentration in the slices of the untreated control groups (open bars) averaged $1.53 \pm 1.23$ and $1.47 \pm 0.52 \mathrm{pmol} / \mathrm{mg}$ protein. respectively. Magnesium concentration in the aCSF of the study groups was increased from $1.3 \mathrm{mM}$ to 3.9 $\mathrm{mM}$ either $2 \mathrm{~h}$ before or immediately after $\mathrm{OGD}$. Values are given as means $\pm \mathrm{SD}$. Each group comprised 5 slices. Intra- and intergroup differences were measured by a two-way analysis of variance followed by Scheffe-F-test (a: $\mathrm{P}<0.05$ OGD vs. Control: $\mathrm{b}$ : $\mathrm{P}<0.05 \mathrm{MgSO}_{4}$ vs. Control).

Table 1. Total Adenylate Pool (TAN) and Adenylate Energy Charge (AEC) in Hippocampal Slices $12 \mathrm{~h}$ after Oxygen-Glucose Deprivation (OGD).

Total Adenylate Pool

\begin{tabular}{|c|c|c|c|c|c|c|c|c|}
\hline \multirow{2}{*}{$\begin{array}{l}\text { Time } \\
\text { (min) }\end{array}$} & \multicolumn{4}{|c|}{$\mathrm{MgSO}_{3} 2 \mathrm{~h}$ hefore $\mathrm{O}$;D } & \multicolumn{3}{|c|}{ MgSO, after $O G: D$} & \\
\hline & Control & & $\mathrm{MgSO}_{\mathrm{g}}$ & & Control & & $\mathrm{MgSO}_{4}$ & \\
\hline Conirol & $100 \pm 17$ & & $106 \pm 11$ & & $100 \pm 11$ & & $107 \pm 10$ & \\
\hline OGD 10 & $97 \pm 18$ & & $106 \pm 8$ & & $83 \pm 10$ & & $90 \pm 10$ & \\
\hline OGD 20 & $84 \pm 12$ & & $108 \pm 13$ & $b$ & $74 \pm 13$ & $a$ & $84 \pm 15$ & a \\
\hline OGD 30 & $66 \pm 9$ & a & $95 \pm 8$ & $b$ & $58 \pm 4$ & a & $58 \pm 6$ & a \\
\hline (KGD 40 & $60 \pm 9$ & a & $82 \pm 7$ & $a b$ & $56 \pm 9$ & $\mathrm{a}$ & $62 \pm 6$ & a \\
\hline
\end{tabular}

\section{Adenylate Energy Charge}

\begin{tabular}{|c|c|c|c|c|c|}
\hline \multirow{2}{*}{$\begin{array}{l}\text { Time } \\
\text { (min) }\end{array}$} & \multicolumn{2}{|c|}{ MgSO, 2 h before $\mathbf{O K}$; } & & \multicolumn{2}{|c|}{$\mathrm{MgSO}_{4}$ alter $\mathrm{OK}: \mathrm{D}$} \\
\hline & Control & $\mathrm{MgSO}_{\mathrm{s}}$ & & Control & $\mathrm{MgSO}_{2}$ \\
\hline Control & $100 \pm 4$ & $103 \pm 1$ & & $100 \pm 2$ & $101 \pm 2$ \\
\hline ()GD I0 & $102 \pm 1$ & $103 \pm 0$ & & $102 \pm 1$ & $101 \pm 1$ \\
\hline (XGD 20 & $99 \pm 7$ & $104 \pm 0$ & & $101 \pm 2$ & $102 \pm 1$ \\
\hline DGD 30 & $101 \pm 2$ & $105 \pm 0$ & $a b$ & $99 \pm 4$ & $90 \pm 2$ \\
\hline OGD 40 & $102 \pm !$ & $104 \pm 1$ & b & $99 \pm 2$ & $99 \pm 3$ \\
\hline
\end{tabular}

Values are given as percent of control imean 2 SD). Each group comprived 5 slices. The absolute

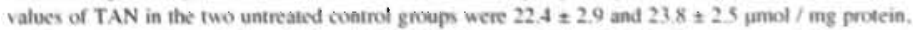
and those of $\mathrm{AEC}$ were $0.92 \pm 0.03$ and $0.93 \pm 0.02$ respectively. Statistically significant differences within and between groups were assessed by ANOVA and the Schelfe post hoc test a. $P<0.05$ (OGD us control); b $P<0.05$ ( MeSO, vs Control) 


\section{DISCUSSION}

Recently, various retrospective clinical studies have shown that the incidence of cerebral palsy in newborns weighing less than $1500 \mathrm{~g}$ can be significantly reduced by administering magnesium to their mothers before birth. The neuroprotective effect was found to be independent of variables such as the administration of tocolytic agents or drugs to accelerate fetal lung development or of any other maternal or fetal risk factors $(4,5)$. Unfortunately, a subsequent study by Grether and co-workers could not confirm the neuroprotective efficacy of magnesium (6). The authors attributed this to changes in medical practice between the two observation periods. A neuroprotective effect of magnesium would be of potential clinical importance, since in contrast to other neuroprotective strategies its application is only very seldom associated with serious complications in either the fetus or the mother (26). A recent study describes an increased paediatric mortality in infants receiving magnesium tocolysis (27). However, few of these children died during the neonatal period and the cause of death could rarely be attributed to the magnesium infusion, thus making a causal link between increased neonatal risk and application of magnesium very unlikely.

A further advantage of using magnesium as a neuroprotective agent would be that the fetus could be treated by application of the drug to the mother, since magnesium crosses the placental as well as the fetal blood brain barrier very easily (28-30). However, experimental studies on application of magnesium in various perinatal modeis of cerebral hypoxia/ischemia have as yet been inconclusive. While a variety of investigations have shown clear neuroprotective effects of magnesium (7-15), this could not be confirmed by others $(14,16,17)$. Postischemic treatment in particular was seen to be ineffective or even to widen the extent of the resulting damage in the neonatal rat model (Levine-model) (14). As already discussed by Sameshima and co-workers this exacerbation of ischemic damage may arise from magnesium-induced hypotension (14). Using the same animal model Vanucci and Ringel reported almost complete ischemia in the ipsilateral brain hemisphere during $2 \mathrm{~h}$ of hypoxia $(3 \mathrm{I}, 32$ ). Although they did not measure regional blood flow after hypoxia-ischemia, reperfusion to the brain hemisphere could possibly occur during an early stage of recovery. Since magnesium can alter vascular tone by blocking neuromuscular junctions, treatment with magnesium after ischemia may quantitatively change blood flow to brain regions during the reperfusion period and result in more severe brain damage. To overcome this problem we used the in vitro system of oxygen-glucose deprivation (OGD) in hippocampal slices prepared from mature guinea pig fetuses: a model that excludes any effect of magnesium on the microcirculation. With this experimental set-up hippocampal slices can be kept metabolically intact for periods of up to $12 \mathrm{~h}$, even when the temperature of the bath is set at $37^{\circ} \mathrm{C}(19,21)$. 
The neuroprotective effect of magnesium on metabolic disturbances of hippocampal slices after prolonged periods of OGD was investigated by measuring tissue levels of highenergy phosphates and protein synthesis (Fig. 1 and 2). Whereas increasing magnesium concentration in the aCSF $2 \mathrm{~h}$ before OGD significantly alleviated metabolic disturbances, treatment immediately after OGD was not effective. Since prolonged inhibition of protein synthesis after an ischemic insult can be viewed as an early marker of neuronal cell damage (33-35), magnesium may also protect the histological integrity of the tissue studied. In fact, protein synthesis has been shown to be reduced both during ischemia and in the early recovery period in vulnerable and non-vulnerable brain areas in vivo (36). At the end of the ischemic period, protein synthesis in non-vulnerable regions begins to recover to preischemic levels, while in vulnerable regions, such as the CA I sector of the hippocampus, it remains low. The latter phenomenon is then followed by neuronal cell loss $(34,35,37,38)$. As shown in recent studies protein synthesis seems to be involved in the cellular suicide programme known as apoptosis. Apoptotic cell death can be prevented by application of the protein synthesis inhibitor, cycloheximide (39). In the present study protein synthesis was reduced by over $40 \% 12 \mathrm{~h}$ after OGD. It cannot be excluded that the generation of apoptotic proteins contributes to the residual protein synthesis rate. However, the resulting neuronal cell damage would then be even more severe. Because the extent of apoptotic cell death after cerebral ischemia seems to depend on the severity of the insult (40-42). the proportion of possible apoptotic cells would be greater in slices subjected to shorter periods of OGD.

Increasing the magnesium concentration in the incubation medium before OGD considerably diminished the increase in CGMP tissue levels $10 \mathrm{~min}$ after OGD. As shown in this (Fig. 3) and previous studies using specific antagonists, the immediate increase in cGMP tissue levels after OGD is a marker of NO-production in this model $(19,20)$. NO is a free radical synthesized by NO-synthase in neurons and endothelial cells in response to increased levels of intracellular calcium. Beside this endothelial and neuronal form of NOsynthase, another form of the enzyme is found in neutrophil granulocytes and microglia. During and to an even greater extent after ischemia NO as well as large numbers of superoxide radicals are produced by NO synthase, xanthine oxidase and via other pathways in the mitochondria. During reperfusion, NO and superoxide radicals combine to produce peroxynitrite, leading to the formation of more potent radicals. Destruction of cerebral tissue is the inevitable result (18),

The neuronal toxicity of NO after cerebral ischemia was elegantly demonstrated by Hamada and co-workers (43). They applied an inhibitor of the NO-synthase to neonatal rats $1.5 \mathrm{~h}$ before an hypoxic-ischemic insult, a procedure that had a highly neuroprotective 
effect. In neonatal mice deficient for neuronal nitric oxide synthase (nNOS) similar results were observed following cerebral ischemia, with a reduction in hippocampal and cortical damage compared to the wild type (44). The neuroprotective effect of magnesium application before OGD seems, therefore, to be mediated in part through its inhibitory effects on NO-production. The inhibition of NO-production may be caused by magnesiumblockade of the NMDA-receptor as well as of voltage-dependent calcium channels, hindering the influx of extracellular calcium into the neurons and thus preventing the activation of the NO-synthase (13; for review: 2 ). In addition, magnesium may exert inhibitory effects of magnesium on NO-synthase. Another mechanism through which magnesium might protect the brain from ischemic injury is through its anti-convulsive properties (45). After an ischemic insult epileptiform activity is often observed in the brain causing an imbalance between blood flow and cell metabolism, which lead to cerebral damage (46). Through its anti-convulsive effects magnesium can diminish epileptiform activity and reduce the extent of possible brain injury. An interesting observation in the present study was that pretreament of hippocampal slices with magnesium did not result in a complete inhibition of cGMP production after OGD. This shows that not all pathophysiological mechanisms causing an activation of NO-synthase are sensitive to magnesium.

In contrast to treatment before OGD, increasing the magnesium concentration in the aCSF after OGD had no impact on cGMP tissue levels. Thus, beside the possible hypotensive effects of magnesium in the postischemic period (14) the neuroprotective inefficacy of post-OGD application may also be attributed to the fact that the NO-production was not inhibited.

After applying L-NNA intravenously to fetal sheep Marks and co-workers observed an increase in ischemic brain injury $(47,48)$. L-NNA is known to block the endothelial form of NO-synthase. This resulted in a reduction in cerebral blood volume after global cerebral ischemia probably through vasoconstriction in the brain. One might argue that in an in vivo preparation reduction of NO production through application of magnesium might be harmful, since inhibition of the endothelial isoform of NO-synthase could result in vasoconstriction. However, given the clear vasodilatory properties of magnesium (49) this objection does not seem to be relevant.

From the present study we conclude that increasing magnesium concentration in the aCSF before OGD alleviates metabolic disturbances in hippocampal slices from mature fetal guinea pigs, whereas treatment after OGD has no effect. This neuroprotection may be mediated in part through the inhibition of NO-production shortly after OGD. 


\section{ACKNOWLEDGEMENT}

The excellent technical assistance of Bianca Lammerding and Stefan Reininghaus is gratefully acknowledged. This work was supported by the Deutsche ForschungsGemeinschaft (DFG Be 1688/4-1) and VERLA-PHARM, Tutzing, Germany.

\section{REFERENCES}

1. Volpe JJ. Neurology of the Newborn. $5^{\text {th }}$ ed. Philadelphia: Saunders, 1995

2. Berger R, Garnier Y. Pathophysiology of perinatal brain damage. Brain Res Brain Res Rev 1999:30:107-34

3. McDonald JW, Johnston MV. Physiological and pathophysiological roles of excitatory amino acids during central nervous system development. Brain Res Rev 1990:15:41-70

4. Nelson KB, Grether JK. Can magnesium sulfate reduce risk of cerebral palsy in very low birthweight infanis? Pediatrics 1995:95:263-69

5. Schendel DE, Berg CJ, Ycargin-Allsopp M, Boyle CA. Decougle P. Prenatal magnesium sulfate exposure and the risk of cerebral palsy or mental retardation among very low-birth-weight children aged 3 to 5 years. JAMA 1996:276:1805-10

6. Grether JK, Hoogstrate J, Walsh-Greene E, Nelson KB. Magnesium sulfate for tocolysis and risk of spastic cerebral palsy in premature children born to women without preeclampsia. Am J Obstet Gynecol 2000;18:717-25

7. Altura BM. Altura BT. Magnesium ions and contraction of vascular smooth muscles: relationship to some vascular diseases. Fed Proc 1981:40:2672-79

8. Choi D. The role of glutamate neurotoxicity in hypoxic-ischemic neuronal death. Ann Rev Neurosci 1990:13:171-82

9. Hallak M, Hotra JW, Kupsky WJ. Magnesium sulfate protection of fetal rat brain from severe maternal hypoxia. Obstet Gynecol 2000;96:124-28

10. Hoffman DJ, Marro PJ, McGowan JE. Mishra OP, Delivoria-Papadopoulos M. Protective effect of $\mathrm{MgSO}_{4}$ infusion on nmda receptor binding characteristics during cerebral cortical hypoxia in the newborn piglet. Brain Res 1994:644:144-9

11. Maulik D. Zanelli S, Numagami Y. Ohnishi ST, Mishra OP. Delivoria-Papadopoulos $M$. Oxygen free radical generation during in-utero hypoxia in the fetal guinea pig brain: the effects of maturity and of magnesium sulfate administration. Brain Res 1999:817:117-22

12. Mishra OP. Delivoria-Papadopoulos M. NMDA receptor modification in the fetal guinea pig brain during hypoxia. Neurochemical Res 1992:17:1211-16

13. Nowak L, Bergestovski P. Ascher P, Herbelt A, Prochiantz A. Magnesium gates glutamate activated channels in mouse central neurons. Nature 1984:307:462-65 
14. Sameshima H, Ota A, Ikenoue T. Pretreatment with magnesium sulfate protects against hypoxic-ischemic brain injury but postasphyxial treatment worsens brain damage in seven-day-old rats. Am J Obstet Gynecol 1999;180:725-30

15. Thordstein M, Bagenholm R, Thiringer K, Kjellmer I. Scavengers of free oxygen radicals in combination with magnesium ameliorate perinatal hypoxic-ischemic brain damage in the rat. Pediatr Res 1993;34:23-26

16. De Haan HH, Gunn AJ, Williams CE, Heymann MA, Gluckman PD. Magnesium sulfate during asphyxia in near-term fetal lambs does not compromize the fetus but does not reduce cerebral injury. Am J Obstet Gynecol 1997;176:18-27

17. Greenwood K, Cox P, Mehmet H, Penrice J, Amess PN, Cady EB, Wyatt JS, Edwards AD. Magnesium sulfate treatment after transient hypoxia-ischemia in the newborn piglet does not protect against cerebral damage. Pediatr Res 2000;48:346-50

18. Beckman JS, Chen J, Ischiropoulos H, Conger KA. Inhibition of nitric oxide synthesis and cerebral protection. In: Krieglstein J, Oberpichler-Schwenk H, eds. Pharmacology of cerebral ischemia. Stuttgart: Wissenschaftliche Verlasggesellschaft mbH. 1992:38394

19. Berger R, Jensen A, Paschen W. Metabolic disturbances in hippocampal slices of fetal guinea pigs during and after oxygen-glucose deprivation: is nitric oxide involved? Neurosci Lett 1998:245:163-66.

20. Paschen W. Comparison of biochemical disturbances in hippocampal slices of gerbil and rat during and after in vitro ischemia. Neurosci Lett 1995:199:41-4

21. Berger R, Djuricic B, Jensen A, Hossmann KA, Paschen W. Ontogenetic differences in energy metabolism and inhibition of protein synthesis in hippocampal slices during in vitro ischemia and $24 \mathrm{~h}$ of recovery. Dev Brain Res 1996;91:281-91

22.Djuricic B, Berger R, Paschen W. Protein synthesis and energy metabolism in hippocampal slices during extended ( 24 hours) recovery following different periods of ischemia. Metab Brain Dis 1994:9:377-89

23. Atkinson DE. The energy charge of the adenylate pool as a regulatory parameter: interaction with feedback modifiers. Biochemistry 1968:7:4030-4

24. Lowry OH, Rosenbrough NJ, Farr AL, Randall R. Protein measurement with the folin phenol reagent. J Biol Chem 1951;193:265-75.

25. Smith CB, Deibler GE, Eng N, Schmidt K, Sokoloff L. Measurement of local cerebral protein synthesis in vivo: influence of recycling of amino acids derived from protein degradation. Proc Natl Acad Sci USA 1988:85:934I-5

26. Lipsitz PJ. The clinical and biochemical effects of excess magnesium in the newborn. Pediatrics 1971:47:501-9

27. Mittendorf R, Covert R, Boman J, Khoshnood B, Lee KS, Siegler M. Is tocolytic magnesium sulphate associated with increased totall paediatric mortality? Lancet. 1997:350:1517-8

28. Cruikshank DP, Pitkin RM, Reynolds WA, Williams GA, Hargis GK. Effects of magnesium sulfate treatment on perinatal calcium metabolism. I. Maternal and fetal responses. Am J Obstet Gynecol 1979:134:243-9 
29. Green KW, Key TC, Coen R, Resnik R. The effects of maternally administered magnesium sulfate on the neonate. Am J Obstet Gynecol 1983;146:29-33

30. Hallak M, Cotton DB. Transfer of maternally administered $\mathrm{MgSO}_{4}$ into the fetal compartment of the rat: Assessment of amniotic fluid, blood, and brain concentrations. Am J Obstet Gynecol 1993;169:427-31

31. Ringel M, Bryan RM, Vannucci RC. Regional cerebral blood flow during hypoxiaischemia in the immature rat: comparison of iodoantipyrine and iodoamphetamine as radioactive tracers. Dev Brain Res 1991:59:231-5

32. Vannucci RC, Lyons DT, Vasta F. Regional cerebral blood flow during hypoxiaischemia in immature rats. Stroke 1998;19:245-50

33. Hossmann KA, Widmann R, Wiessner Ch, Dux E, Djuricic B. Röhn G. Protein synthesis after global ischemia and selective vulnerability. In: Krieglstein J, Oberpichler-Schwenk H, eds. Pharmacology of Cerebral Ischemia. Stuttgart: Wissenschaftliche Verlagsgesellschaft mbH, 1992:289-99

34. Hossmann KA. Disturbances of cerebral protein synthesis and ischemic cell death.Prog Brain Res 1993;96:161-77

35. Hossmann KA. Ischemia-mediated neuronal injury. Resuscitation 1993:26:225-35

36. Kleihues P, Hossmann KA, Pegg AE, Kobayashi K und Zimmermann V. Resuscitation of the monkey brain after one hour of complete ischemia III. Indications of metabolic recovery. Brain Res 1975;95:61-73

37. Bodsch W, Takahashi K, Barbier A, Ophoff BG, Hossmann KA. Cerebral protein synthesis and ischemia. Prog Brain Res 1985:63:197-210

38. Thilmann R, Xie Y, Kleihues P, Kiessling M. Persistent inhibition of protein synthesis precedes delayed neuronal cell death in postischemic gerbil hippocampus. Acta Neuropathol 1986:71:88-93

39. Goto K, Ishige A, Sekiguchi K, lizuka S, Sugimoto A. Yuzurihara M, Aburada M. Hosoya E, Kogure K. Effects of cycloheximide on delayed neuronal death in rat hippocampus. Brain Res 1990;534:299-302

40. Dragunow M, Beilharz E, Sirimanne E, Lawlor P, Williams CE, Bravo R, Gluckman. PD. Immediate-early gene protein expression in neurons tundergoing delayed death. but not necrosis, following hypoxic-ischemic injury to the young rat brain. Molecular Brain Res 1994:25: 19-33

41. Li Y. Chopp M, Zhang ZG, Zaloga C. Induction of DNA fragmentation after 10 to 120 minutes of focal cerebral ischemia in rats. Stroke 1995:26: 1252-8

42. Mehmet H, Yue X, Squier MV. Lorek A. Cady E. Penrice J, Sarraf C. Wylezinska M. Kirkbridge V, Cooper C, Brown GC, Wyatt IS, Reynolds EOR, Edwards AD. Increased apoptosis in the cingulate sulcus of newborn piglets following transient hypoxia-ischemia is related to the degree of high energy phosphate depletion during the insult. Neurosci Lett 1994:181: 121-5.

43. Hamada Y. Hayakawa T, Hattori H. Mikawa H. Inhibitor of nitric oxide synthesis reduces hypoxic-ischemic brain damage in the neonatal rat. Pediatr Res 1994:35:10-4 
44. Ferriero DM, Holtzman DM, Black SM, Sheldon RA. Neonatal mice lacking neuronal nitric oxide synthase are less vulnerable to hypoxic-ischemic injury.Neurobiol Dis 1996:3:64-71

45. American College of Obstetricians and Gynecologists. Hypertension in pregnancy, ACOG technical bulletin no. 219, Washington DC, 1996

46. Hossmann KA. Mechanisms of ischemic injury: is glutamate involved? In: Krieglstein J, Oberpichler-Schwenk H, eds. Pharmacology of Cerebral Ischemia. Stuttgart: Wissenschaftliche Verlagsgesellschaft GmbH, 1994:239-51

47. Marks KA, Mallard CE, Roberts I, Williams CE, Gluckman PD, Edwards AD. Nitric oxide synthase inhibition attenuates delayed vasodilation and increases injury after cerebral ischemia in fetal sheep. Pediatr Res 1996;40:185-91

48. Marks KA, Mallard CE, Roberts I, Williams CE, Gluckman PD, Edwards AD. Nitric oxide synthase inhibition and delayed cerebral injury after severe cerebral ischemia in fetal sheep. Pediatr Res 1999;46:8-13

49. Seelig JM, Wei EP, Kontos HA, Choi SC, Becker DP. Effect of changes in magnesium ion concentration on cat cerebral arterioles. Am J Physiol 1983;245:H22-6 


\section{Chapter 9}

\section{EFFECTS OF MILD HYPOTHERMIA ON METABOLIC DISTURBANCES IN FETAL HIPPOCAMPAL SLICES AFTER OXYGEN-GLUCOSE DEPRIVATION DEPEND ON DEPTH AND TIME DELAY OF COOLING}

Garnier Y, Pfeiffer D, Jensen A, Berger R Journal of the Society for Gynecologic Investigation, 2001;8:198-205 


\section{ABSTRACT}

Objective: There is a growing body of evidence from animal experiments that mild hypothermia induced during or even after cerebral ischemia may protect the immature brain from neuronal cell damage. However, the exact interrelation between the postischemic time delay and the degree of mild hypothermia by which neuroprotective effects on ischemic insults of different severity can be achieved has not yet been systematically elucidated. To clarify this point we studied the interaction between these variables in a recently modified hippocampal slice model.

Methods: We investigated the recovery of energy metabolism and protein synthesis rate (PSR) in hippocampal slices from mature fetal guinea pigs after 20,30 or $40 \mathrm{~min}$ of oxygen-glucose deprivation (OGD). Hypothermia of varying degrees was induced immediately, $2 \mathrm{~h}$ or $4 \mathrm{~h}$ afier OGD and lasted for $12 \mathrm{~h}$. Prolonged inhibition of PSR after ischemia has been shown to be a particularly sensitive marker of neuronal cell damage.

Results: Hypothermia initiated directly after OGD significantly improved the recovery of energy metabolism and PSR. If there was a time delay of $2 \mathrm{~h}$ in the onset of hypothermia, neuroprotection depended on the degree of hypothermia. Reduction of the incubation temperature to $31^{\circ} \mathrm{C}$ diminished the disturbances of energy metabolism and PSR, whereas lowering the bath temperature to only $34^{\circ} \mathrm{C}$ was not effective. Inducing hypothermia $4 \mathrm{~h}$ after OGD did not have any influence on the recovery of energy metabolism and PSR.

Conclusion: From this study we conclude that the effects of mild hypothermia on metabolic disturbances in hippocampal slices of mature fetal guinea pigs depend on the intervention delay and the degree of cooling. The shorter the postischemic intervention delay and the greater the degree of hypothermia, the better the neuroprotective effect seems to be. 


\section{INTRODUCTION}

Children undergoing hypoxic-ischemic brain damage during birth often suffer from the drastic consequences of this misfortune for the rest of their lives (1). Despite the many farreaching consequences of this kind of perinatal insult, the range of effective therapeutic measures available is disturbingly limited (2). However, over the last few years increasing evidence has been obtained from animal experiments that mild hypothermia, i.e. lowering the brain temperature by only a few degree of Celsius, induced during or immediately after cerebral ischemia may protect the immature brain from neuronal cell damage (3-10). Moreover, as shown by recent studies on fetal sheep, hypothermia induced even several hours after cerebral ischemia seems to diminish brain injury $(11,12)$. In contrast to investigations on adult animals (13-18), the exact relation between the postischemic time delay and the degree of mild hypothermia by which neuroprotective effects on ischemic insults of different severity can be achieved has not yet been systematically elucidated in one experimental model in immature animals.

However, if this point were to be clarified in an in vivo model of fetal cerebral ischemia various problems would be encountered: First of all a number of experimental variables such as cerebral blood flow, arterial oxygen saturation, blood glucose concentration, catecholamine release etc. have to be kept within very narrow limits, since each of these variables is known to affect neuronal cell loss after an ischemic insult (for review 2). The scatter in the neuronal outcome in a whole animal preparation is therefore usually larger than in an in vitro model in which experimental conditions can be easily kept constant or changed over a wide range. When studying a large experimental protocol, with multiple relations between several variables, possible differences between controls and treated groups may remain undetected in an in vivo model due to a considerable scatter in the experimental outcome, i,e. extent of brain injury. For this reason we used a recently modified hippocampal slice model $(3,19)$, in which changes in metabolic disturbances during and after oxygen/glucose deprivation have been shown to vary within very narrow limits. As markers. for neuronal cell injury we measured energy metabolism and protein synthesis rate (PSR). Prolonged inhibition of PSR after ischemia has been shown to be a particularly sensitive marker of neuronal cell damage (20). To elucidate the relation between the postischemic time delay and the degree of mild hypothermia by which neuroprotective effects on ischemic insults of different severity can be achieved we measured the recovery of energy metabolism and PSR in hippocampal slices from mature fetal guinea pigs after 20 to 40 min of oxygen/glucose deprivation (OGD). Hypothermia of varying degrees was induced immediately, 2 h or $4 \mathrm{~h}$ after OGD and lasted for $12 \mathrm{~h}$. 


\section{METHODS}

Experiments were performed on mature guinea pig fetuses (E 60; 0.9 of gestation). Tissue slices were prepared and incubated as described recently $(3,19)$. For the present study we preferred tissue slices from the hippocampal area, since this region is known to be very sensitive to hypoxic-ischemic insults in comparison with other parts of the brain $(20,21)$.

Guinea pig dams were anesthetized with halothane. The fetuses were delivered by cesarean section and decapitated. Until further preparation the fetal heads were kept in ice-water. The skull was then cut along the midline with scissors and removed with forceps. After removal of the skull the brainstem was divided below the cerebellum. The hemispheres were lifted with a spaiula and the cranial nerves and the blood vessels were cut to allow the brain to fall gently into a beaker containing ice-cold artificial cerebrospinal fluid (aCSF) $\left(0^{\circ} \mathrm{C}\right)$. This temperature was strictly maintained throughout the slice preparation period, since preliminary experiments have shown that preservation of cellular metabolism is improved under these conditions. Standard aCSF (22) contained (in mM): $\mathrm{NaCl}, 11 \mathrm{l}$; $\mathrm{NaHCO}_{3}, 26 ; \mathrm{KCl}, 3 ; \mathrm{KH}_{2} \mathrm{PO}_{4}, 1.4 ; \mathrm{CaCl}_{2}, 1.2 ; \mathrm{MgSO}_{4}, 1.3 ;$ glucose, 10 (standard) or 2 (low glucose; in low glucose aCSF $\mathrm{NaCl}$ was adjusted to $115 \mathrm{mM}$ ); and $\mathrm{N}-[2$ hydroxyethyl]piperazine- $N^{*}$-[2-ethanesulfonic acid] (HEPES), 5. The aCSF was supplemented with amino acids $(\mu \mathrm{M})(22)$ : alanine, 34: arginine, 22; aspartate, 0.13; citrulline, 5.7; cystine, 0.12 ; histidine, 13: lysine, 27.7; methionine, 3.4; ornithine, 3.8: phenylalanine, 9.1 ; serine, 28.5 ; taurine, 8 ; threonine, 32 ; tryptophan. 1.5: tyrosine, 8.3 ; valine, 12.8. To prevent bacterial contamination $10 \mathrm{mg} / \mathrm{L}$ each of streptomycin and erythromycin were added to the aCSF. The aCSF was equilibrated with a gas mixture of $\mathrm{O}_{2} / \mathrm{CO}_{2}(95 \% / 5 \%)$ for at least 60 min prior to the experiments. The $\mathrm{pH}$ of the aCSF was adjusted to 7.4 with $1 \mathrm{M} \mathrm{NaOH}$ or $1 \mathrm{M} \mathrm{HCl}$. For further preparation the fetal brain was transferred from the beaker onto a cooling plate $\left(0^{\circ} \mathrm{C}\right)$ covered with filter paper. The filter paper was moistened with aCSF. The brain was divided into its two halves and the hemispheres were placed with the lateral side down. The brain stem was lifted with a spatula, while the occipital cortex was gently pushed downwards with another spatula until the whole medial and inferior side of the hippocampal formation could be seen. Both ends of the structure were then freed and the hippocampus was rolled upwards and backwards towards the occipital pole by inserting spatulas on both sides under its superior surface. The hippocampal formation now lay with the dentate area down and the alveus up. The hippocampi were then transferred again to chilled standard aCSF until they were cut into slices of $500 \mu \mathrm{m}$ thickness on a tissue slicer (Rademacher, Cologne. Germany). Before use the tissue slicer had been pre-cooled in a refrigerator. The slices were transferred from the chopper onto a nylon mesh with a painting brush. The nylon mesh was stretched across a plastic ring and immersed in standard aCSF. The incubation took place in a temperature 
controlled $\left(37^{\circ} \mathrm{C}\right)$ flow-through chamber, gassed with $\mathrm{O}_{2} / \mathrm{CO}_{2}(95 \% / 5 \%)$ for $90 \mathrm{~min}$. The flow rate of the aCSF was set to $1 \mathrm{~mL} / \mathrm{min}$. Care was taken to ensure that the upper side of the slices was fully exposed to the warm humidified gas mixture, while the underside was lying in aCSF. After the slices had been allowed to recover from the initial preparation stress for $90 \mathrm{~min}$, the flow rate through the chamber was increased to $3 \mathrm{~mL} / \mathrm{min}$ and standard aCSF with low glucose $(2 \mathrm{mM})$ was pumped through for $30 \mathrm{~min}$. This incubation of slices in low glucose aCSF was introduced to produce a prompt depletion of high energy phosphates during OGD (22).

The experimental protocol consisted of a preincubation period (120 min) and an anoxic period (20, 30 or $40 \mathrm{~min}$ OGD) followed by a recovery period with zero time corresponding to the end of the anoxic period (Fig. 1). We decided to vary the duration of OGD, since it is conceivable that the extent of the neuroprotective effect of mild hypothermia may depend on the severity of the insult. Hence, hypothermia may fail to protect tissue slices from metabolic disturbances, if the primary insult is too severe. To induce OGD an additional incubation chamber was set up that was gassed with a mixture of $\mathrm{N}_{2} / \mathrm{CO}_{2}(95 \% / 5 \%)$.

Oxygen/glucose-deprived aCSF was prepared in the same manner as standard aCSF except for the addition of HEPES and glucose. HEPES was removed from oxygen/glucosedeprived aCSF, since it provides additional buffering capacity. This could influence the decrease in $\mathrm{pH}$ during $\mathrm{OGD}$ and alter the tissue response to OGD. Slight changes in osmolarity owing to the removal of glucose and HEPES were compensated by adjusting the $\mathrm{NaCl}$ concentration. Before transferring slices to the anoxic chamber, glucose was washed out of the tissue by immersion of the slices in oxygenated, aglycemic aCSF for 2 min. The post-OGD period was initiated by transferring slices to standard aCSF (flow rate ! $\mathrm{mL} / \mathrm{min}$ ) with $\mathrm{O}_{2} / \mathrm{CO}_{2}(95 \% / 5 \%)$. Mild hypothermia was induced immediately, $2 \mathrm{~h}$ or $4 \mathrm{~h}$ after OGD by lowering the incubation temperature to $34^{\circ} \mathrm{C}$ or $31^{\circ} \mathrm{C}$, respectively. The hypothermic period lasted for $12 \mathrm{~h}$. At the end of the experiments tissue concentrations of adenylates and protein synthesis were determined in slices of the control and intervention groups. Each experiment (normothermia vs. hypothermia) consisted of a normothermic control group and a hypothermic group without OGD. In addition, there were three normothermic and three hypothermic groups of slices that underwent OGD ( $20-40 \mathrm{~min}$ ) (Fig. 1). 


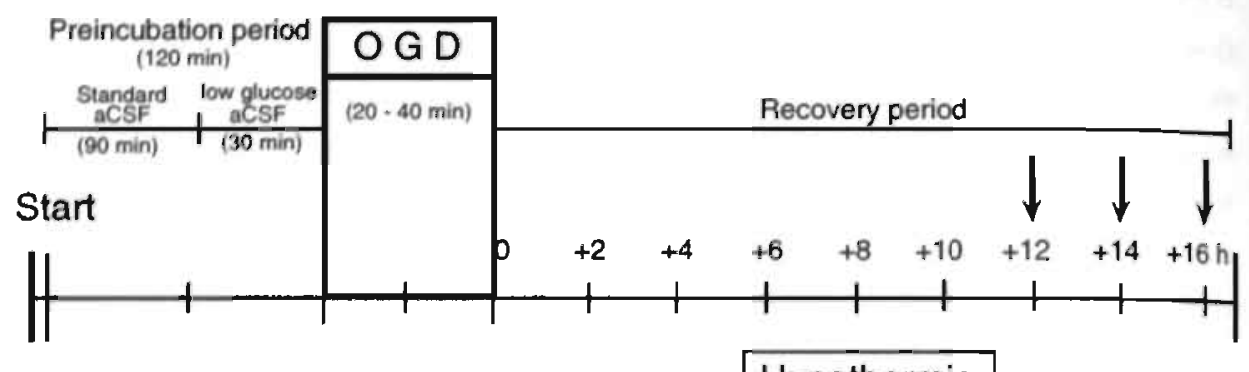

Hypothermia

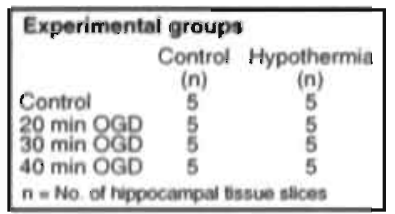

$0<^{\text {Hypothermia } 34^{\circ} \mathrm{C} \text { or } 31^{\prime \prime} \mathrm{C}(12 \mathrm{~h} \text { recovery) }}$

$+24^{\text {Hypothermia } 34^{\circ} \mathrm{C} \text { or } 31^{\circ} \mathrm{C}(12 \mathrm{~h} \text { recovery) }}$

$+4 \leqslant$ Hypothermia $34^{\circ} \mathrm{C}$ or $31^{\circ} \mathrm{C}$ (12 h recovery)

Sampling of hippocampal tissue slices after $12 \mathrm{~h}$ of hypothermia $\left(34^{\circ} \mathrm{C}\right.$ or $\left.31^{\circ} \mathrm{C}\right)$ for

analysis of adenylates (ATP; ADP; AMP) and protein synthesis rate (PSP)

Fig 1. The experimental protocol consisted of a preincubation period ( $120 \mathrm{~min}$ ) and an anoxic period (20.30 or $40 \mathrm{~min}$ OGD) followed by a recovery period with zero time corresponding to the end of the anoxic period To induce OGD, an additional incubation chamber was set up that was gassed with a mixture of $\mathrm{N}_{2} / \mathrm{CO}_{2}$ $(95 \% / 5 \%)$. Mild hypothermia was induced immediately. $2 \mathrm{~h}$ or $4 \mathrm{~h}$ after OGD by lowering the incubation temperature $1034^{\circ} \mathrm{C}$ of $31^{\circ} \mathrm{C}$, respectively. The hypothermic period lasted for $12 \mathrm{~h}$. At the end of the experiments tissue concentrations of adenylates and protein synthesis were determined in slices of the control and intervention groups. Each experiment (normothermia vs. hypothermia) consisted of a normothermic control group and a hypothermic group without OGD. in addition, there were three normothermic and three hypothermic groups of slices that underwent OGD (20-40 min).

The concentrations of adenylates in the tissue slices were measured in the supernatant of neutralized tissue homogenates by high-pressure liquid chromatography after extraction with perchloric acid (19). The adenylate energy charge (AEC), a measure of the balance between energy consumption and energy production was calculated as follows (23): AEC $=([\mathrm{ATP}]+0.5[\mathrm{ADP}]) /([\mathrm{ATP}]+[\mathrm{ADP}]+[\mathrm{AMP}])$ : where ATP is adenosine triphosphate: ADP is adenosine diphosphate; and AMP is adenosine monophosphate. The protein content of the tissue slices was measured by the Lowry method (24).

The rate of incorporation of ${ }^{14} \mathrm{C}$-leucine into tissue proteins was taken as a measure of PSR. For these readings, 30 min before the conclusion of the experiments the tissue slices were

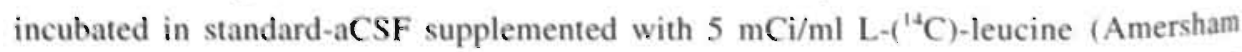
Buchler, Braunschweig, Germany: specific activity: $54 \mathrm{mCi} / \mathrm{mMol}$ ). The slices remained 
there for $30 \mathrm{~min}$ and were homogenized in trichloroacetic acid. The radioactivity of the precipitate was measured by liquid scintillation spectrometry after proteins had been dissolved in $1 \mathrm{M} \mathrm{NaOH}$ (19). The histological status of the tissue had been investigated in some pilot experiments. Severe deterioration of the tissue could be excluded after an incubation period of up to $24 \mathrm{~h}$.

In contrast to previously described hippocampal slice models, we used an interface technique in which the upper side of the slices was fully exposed to the warm humidified gas mixture while the underside was lying in aCSF. In addition, the slices were kept in a flow-through chamber and the aCS.F was supplemented with amino acids. Using this technique, energy metabolism and protein synthesis can be kept constant for up to $24 \mathrm{~h}$ as shown in a variety of previous studies $(3,19,22)$. This is especially true of slices from mature fetuses, since they are much less vulnerable to the preparation procedure than those from adult animals $(3,19)$. As shown in a recent study , hippocampal slices from mature fetal guinea pigs are completely depleted of ATP after 20 to $40 \mathrm{~min}$ of OGD. Within $24 \mathrm{~h}$ a partial recovery in the tissue concentration of ATP can be seen. The extent of the recovery ranges from 40 to $90 \%$ of control levels depending on the duration of $\operatorname{OGD}(3,19)$.

\section{Statistics}

The values are presented as means, \pm SD. The data for each experimental group was obtained from 4 to 5 tissue slices. We restricted statistical analysis to each single experiment, which consisted of 8 groups of slices, i.e. a normothermic control group, a hypothermic group without OGD as well as three normothermic and three hypothermic groups of slices that underwent OGD (20-40 min). Significant differences within and between groups were assessed using ANOVA and Scheffés F-test.

\section{RESULTS}

The concentrations of ATP measured in hippocampal slices from mature guinea pig fetuses are shown as $\%$ control in Fig 2. The ATP tissue levels in the five untreated control groups averaged $18.2 \pm 4.2 \mu \mathrm{mol} / \mathrm{mg}$ protein. At the end of the recovery period, ATP concentration in the hippocampal slices was significantly reduced by up to $50 \%$ depending on the severity of OGD. Moreover, the decrease in ATP concentration was clearly diminished by induction of hypothermia immediately after OGD. The maximum difference $(27 \%)$ could be observed between slices that underwent $40 \mathrm{~min}$ of OGD and were kept either normothermic or hypothermic at $34^{\circ} \mathrm{C}$. If hypothermia was not initiated until $2 \mathrm{~h}$ 
after OGD, significant alleviation of the fall in ATP tissue levels after OGD could only be observed at an incubation temperature of $31^{\circ} \mathrm{C}$ (maximum difference $19 \%$ ). Inducing hypothermia $4 \mathrm{~h}$ after OGD did not have any impact on ATP concentrations in fetal hippocampal slices except for a slight difference in the groups that underwent $20 \mathrm{~min}$ of OGD.

The tissue content of adenylates as well as the adenylate energy charge in hippocampal slices are given in Tables 1 and 2. Total adenylate pool and adenylate energy charge in the five untreated control groups averaged $20.9 \pm 4.7 \mu \mathrm{mol} / \mathrm{mg}$ protein and $0.91 \pm 0.03$ respectively. The time course in changes of total adenylate pool after OGD and hypothermia closely resembled that of ATP concentrations (Table 1; Fig. 2). Adenylate energy charge scarcely differed at all from control values at the end of the recovery period (Table 2).

Table 1. Total Adenylate Pool

\begin{tabular}{|c|c|c|c|c|c|c|}
\hline \multicolumn{7}{|c|}{ Onset of Hypothermia $\left(34^{\circ} \mathrm{C}\right)$} \\
\hline & \multicolumn{2}{|c|}{ Immediately after OGD } & \multicolumn{4}{|c|}{ 2h after $O G D$} \\
\hline & Control & Hypothermla & Control & Hypothermia & & \\
\hline Control & $100 \pm 15$ & $109 \pm 10$ & $100 \pm 12$ & $103 \pm 5$ & & \\
\hline $20 \mathrm{~min} O G D$ & $76 \pm 7$ & $84 \pm 7$ & $69 \pm 13^{a}$ & $81 \pm 10^{\mathrm{a}}$ & & \\
\hline $.4 \mathrm{mln}$ OGD & $75 \pm 19$ & $80 \pm 6^{\mathrm{a}}$ & $66 \pm 7^{a}$ & $74 \pm 9^{a}$ & & \\
\hline $40 \mathrm{~m} / \mathrm{n} O \mathrm{OBD}$ & $53 \pm 8^{\mathrm{a}}$ & $82 \pm 20^{a, b}$ & $52 \pm 15^{\mathrm{a}}$ & $48 \pm 8^{a}$ & & \\
\hline \multicolumn{7}{|c|}{ Onset of Hypothermin $\left(31^{\circ} \mathrm{C}\right.$ ) } \\
\hline & \multicolumn{2}{|c|}{ Immediately after OGD } & \multicolumn{2}{|c|}{$2 \mathrm{~h}$ after $\mathrm{OGD}$} & \multicolumn{2}{|c|}{ th after OGD } \\
\hline & Control & Hypothernin & Control & Hypothermia & Control & Hypothermia \\
\hline Control & $100 \pm 15$ & $109 \pm 7$ & $100 \pm 9$ & $102 \pm 18$ & $100 \pm 16$ & $109 \pm 3$ \\
\hline 20 min OGD & $69 \pm 11^{a}$ & $80 \pm 16^{\mathrm{a}}$ & $71 \pm 6^{\mathrm{a}}$ & $78 \pm 8^{a}$ & $83 \pm 11$ & $68 \pm 6^{a} \cdot b$ \\
\hline 30 min OGiD & $46 \pm 8^{a}$ & $69 \pm 12^{a, b}$ & $61 \pm 6^{\mathrm{a}}$ & $78 \pm 8^{a} \cdot b$ & $50 \pm 3^{\mathrm{a}}$ & $57 \pm 4^{3}$ \\
\hline $40 \mathrm{~min}$ OGD & $44 \pm 6^{\mathrm{a}}$ & $62 \pm 16^{a} \cdot b$ & $54 \pm 7^{\mathrm{a}}$ & $69 \pm 8^{a, b}$ & $42 \pm 6^{\mathrm{a}}$ & $48 \pm 8^{a}$ \\
\hline
\end{tabular}

Total adenylate pool $\Sigma($ ATP + ADP + AMP) in hippocampal slices from mature guinea pig fetuses $20-40$ mins after oxygen/glucose deprivation (OGD) and $12 \mathrm{~h}$ of hypothermia. In the study groups incubation temperature was reduced to $34^{\circ} \mathrm{C}$ or $31^{\circ} \mathrm{C}$ immediately, $2 \mathrm{~h}$ or $4 \mathrm{~h}$. after OGD. Total adenylate concentration in the five untreated control group was $20.9 \pm 4.7 \mu \mathrm{mol} / \mathrm{g}$. Intra- and intergroup differences were measured by a two-way analysis of variance followed by Scheffe-F-test (a: $\mathrm{P}<0.05 \mathrm{OGD}$ vs. control: $\mathrm{b}: \mathrm{P}<0.05$ hypothermia vs, normothermia). 
Table 2. Adenylate Energy Charge

\begin{tabular}{|c|c|c|c|c|c|c|}
\hline \multicolumn{7}{|c|}{ Onset of Hypothermia $\left(34^{\circ} \mathrm{C}\right)$} \\
\hline & \multicolumn{2}{|c|}{ Immediately after $\mathrm{OGD}$} & \multicolumn{4}{|c|}{ 2h after $O G D$} \\
\hline & Control & Hypothermia & Control & Hypothermia & & \\
\hline Centrol & $100 \pm 4$ & $98 \pm 2$ & $100 \pm 3$ & $103 \pm 1$ & & \\
\hline $20 \mathrm{~min}$ OGD & $97 \pm 3$ & $98 \pm 2$ & $92 \pm 11$ & $100 \pm 3$ & & \\
\hline $30 \mathrm{~min}$ OGD & $88 \pm 12$ & $94 \pm 4$ & $97 \pm 3$ & $96 \pm 4^{\mathrm{a}}$ & & \\
\hline $40 \mathrm{~min}$ OGD & $89 \pm 6$ & $92 \pm 8$ & $88 \pm 5$ & $92 \pm 3^{a}$ & & \\
\hline \multicolumn{7}{|c|}{ Onset of Hypothermia (31 ${ }^{\circ} \mathrm{C}$ ) } \\
\hline & Control & Hypothermia & Control & Hypothermia & Control & Hypothermia \\
\hline Control & $100 \pm 3$ & $102 \pm 3$ & $100 \pm 1$ & $101 \pm 2$ & $100 \pm 1$ & $101 \pm 1$ \\
\hline $20 \min$ OGD & $101 \pm 3$ & $102 \pm 3$ & $103 \pm 3$ & $104 \pm 1$ & $101 \pm 2$ & $97 \pm 4$ \\
\hline $30 \mathrm{~min}$ OGD & $101 \pm 1$ & $102 \pm 3$ & $100 \pm 2$ & $102 \pm 3$ & $99 \pm 2$ & $98 \pm 2$ \\
\hline 40 $\min$ OGD & $97 \pm 5$ & $102 \pm 4$ & $100 \pm 6$ & $102 \pm 2$ & $96 \pm 2^{\mathrm{a}}$ & $97 \pm 2$ \\
\hline
\end{tabular}

The adenylate energy charge (ATP + 0.5 ADP) / ¿ (ATP + ADP + AMP) in hippocampal slices from mature guinea pig fetuses 20 - 40 mins after oxygen/glucose deprivation (OGD) and $12 \mathrm{~h}$ of hypothermia. in the study groups incubation temperature was reduced to $34^{\circ} \mathrm{C}$ or $31^{\circ} \mathrm{C}$ immediately, $2 \mathrm{~h}$ or $4 \mathrm{~h}$ after OGD. The adenylate energy charge in the five untreated control groups averaged $0.91 \pm 0.03$. Intra- and intergroup differences were determined by a two-way analysis of variance followed by Scheffé-F-test (a: $\mathrm{P}<0.05$ OGD vs. control: b: $\mathrm{P}<0.05$ hypothermia vs. normothermia).

The PSR in hippocampal slices measured as incorporation of ${ }^{14} \mathrm{C}$-leucine into tissue proteins is illustrated in fig. 3. PSR in the five untreated control groups averaged $124 \pm 47$ $\mathrm{dpm} / 30 \mathrm{~min} / \mu \mathrm{g}$ protein. Like energy metabolism, PSR was inhibited by up to $40 \%$ depending on the intensity of the OGD. Hypothermia, initiated at the end of the OGD period, significantly improved the recovery of PSR (maximum difference $25 \%$ ). Furthermore, inhibition of PSR could be alleviated, if the temperature of the bath medium was reduced to $31^{\circ} \mathrm{C} 2 \mathrm{~h}$ after OGD. The maximum difference $(29 \%)$ could be observed between slices that underwent $40 \mathrm{~min}$ of OGD. Inducing hypothermia $4 \mathrm{~h}$ after OGD had no influence on the recovery of PSR. The impact of hypothermia of $34^{\circ} \mathrm{C}$ commencing $4 \mathrm{~h}$ after OGD on metabolic disturbances of hippocampal slices has not been studied, since under these conditions no effect could be observed even when the incubation temperature was lowered $2 \mathrm{~h}$ after the insult. 


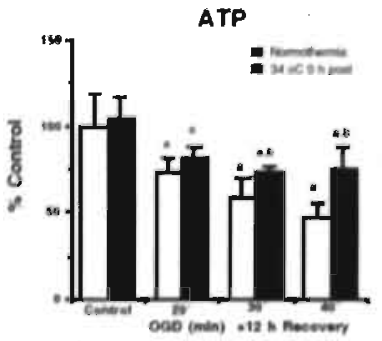

A

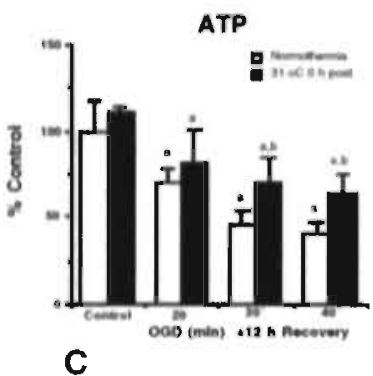

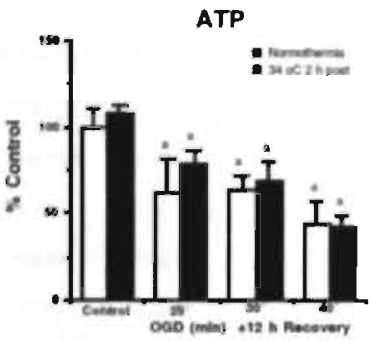

B

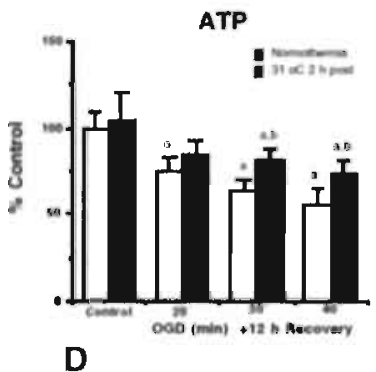

ATP

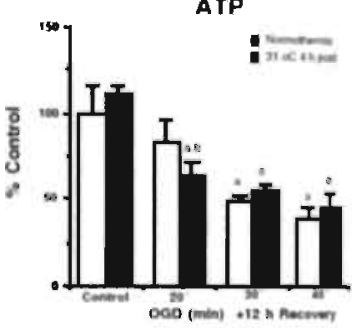

E

Figure 2. ATP tissue concentration ( $\%$ of control) in hippocampal slices of mature guinea pig fetuses $20-40$ mins after oxygen/glucose deprivation (OGD) followed by $12 \mathrm{~h}$ of hypothermia. Incubation temperature was reduced from $37^{\circ} \mathrm{C}$ to $34^{\circ} \mathrm{C}$ or $31^{\circ} \mathrm{C}$ immediately [A $\left.\left(34^{\circ} \mathrm{C}\right): \mathrm{C}\left(3 \mathrm{i}^{\circ} \mathrm{C}\right)\right], 2 \mathrm{~h}\left[\mathrm{~B}\left(34^{\circ} \mathrm{C}\right) ; \mathrm{D}\left(3 \mathrm{I}^{\circ} \mathrm{C}\right)\right]$ or $4 \mathrm{~h}$ [ $\mathrm{E}$ $\left.\left(3 \mathrm{I}^{\prime} \mathrm{C}\right)\right]$ after $\mathrm{OGD}$. ATP tissue concentrations in the five untreated control groups averaged. $[8.2 \pm 4.2 \mu \mathrm{mol} /$ mg protein. Values are given as means $\pm S D$. Intra- and intergroup differences were measured by a two-way analysis of variance followed by Scheffé-F-test (a: $\mathrm{P}<0.05 \mathrm{OGD}$ vs. Control: $\mathrm{b}: \mathrm{P}<0.05$ Hypothermia vs. Normothermia).

\section{DISCUSSION}

In recent years, a large number of studies have been performed in fetal as well as in. neonatal animals elucidating the neuroprotective effect of mild hypothermia on hypoxicischemic insults (3-10). Furthermore, there is also evidence that hypothermia, even when induced several hours after $30 \mathrm{~min}$ of cerebral ischemia, protects fetal sheep from brain injury (12). However, the exact relation between the postischemic time delay and the degree of mild postischemic hypothermia at which neuroprotective effects can be achieved on ischemic insults of different severity has not yet been systematically elucidated in one experimental model in immature animals. To clarify this point we studied the interaction between these variables in a recently modified hippocampal slice model $(3,19)$. 


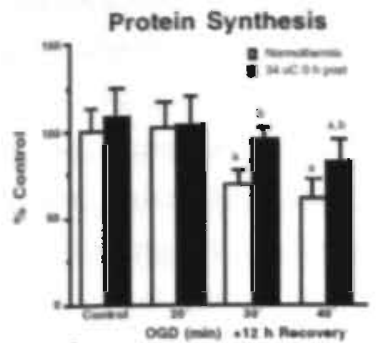

A

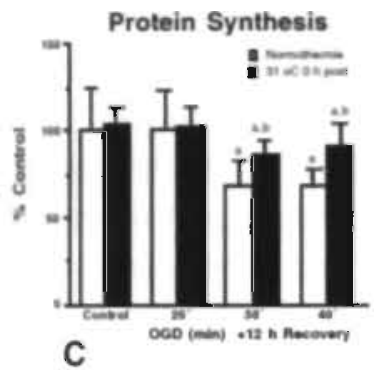

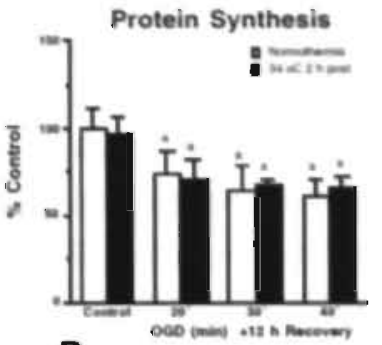

B

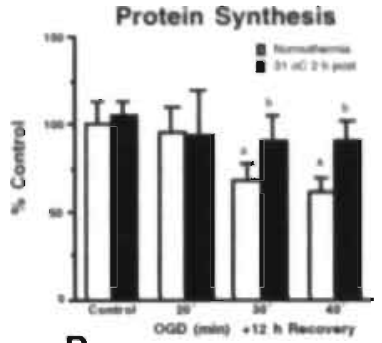

D

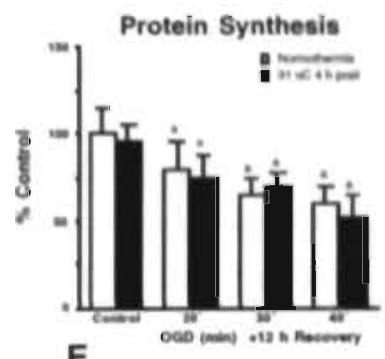

E

Figure 3. Protein synthesis rate (PSR) ( $\%$ of control) in hippocampal slices of mature guinea pig fetuses 20 40 mins after oxygen/glucose deprivation (OGD) followed by $12 \mathrm{~h}$ of hypothermia. Incubation temperature was reduced from $37^{\circ} \mathrm{C}$ to $34^{\circ} \mathrm{C}$ or $31^{\prime \prime} \mathrm{C}$ immediately [A $\left.\left(34^{\circ} \mathrm{C}\right) ; \mathrm{C}\left(31^{\circ} \mathrm{C}\right)\right], 2 \mathrm{~h}\left[\mathrm{~B}\left(34^{\circ} \mathrm{C}\right): \mathrm{D}\left(31^{\circ} \mathrm{C}\right)\right]$ or $4 \mathrm{~h}$ [E $\left.\left(3 !^{\prime} \mathrm{C}\right)\right]$ after OGD. PSR in the five untreated control groups averaged $124 \pm 47 \mathrm{dpm} ! 30 \mathrm{~min} ! \mathrm{g}$ protein. Values are given as means \pm SD. Intra- and intergroup differences were measured by a two-way analysis of variance followed by Scheffé-F-test ( $\mathrm{a}: \mathrm{P}<0.05 \mathrm{OGD}$ vs. Control; $\mathrm{b}: \mathrm{P}<0.05$ Hypothermia vs. Normothermia).

Hypothermia initiated directly after OGD significantly improved the recovery of energy metabolism and PSR. If there was a time delay of $2 \mathrm{~h}$ in the onset of hypothermia, neuroprotection depended on the degree of hypothermia. Whereas reduction of the incubation temperature to $31^{\circ} \mathrm{C}$ diminished the disturbances in energy metabolism and PSR, lowering the bath temperature to $34^{\circ} \mathrm{C}$ was found to be ineffective. The intervention delay of $2 \mathrm{~h}$ is quite consistent with a recently published in vivo study on fetal sheep (11). where the extradural temperature was reduced to $32.4 \pm 0.8^{\circ} \mathrm{C}$ by placing a cooling coil over the fetal scalp connected to a pump in a cooled water bath. After $5 \mathrm{~d}$ of recovery there was a dramatic reduction in brain injury. In the present study, if hypothermia was first initiated $4 \mathrm{~h}$ after OGD, a neuroprotective effect was no longer observed. These results contradict a previous publication on fetal sheep illustrating a reduction in neuronal damage 
due to delayed hypothermia induced $5.5 \mathrm{~h}$ after cerebral ischemia (12). However, this could be accounted for by the different experimental models used in the two studies. Hypothermia induced $8.5 \mathrm{~h}$ after cerebral ischemia has recently been shown to be ineffective in preventing brain injury in fetal sheep (25). Although these studies on fetal sheep have elucidated the time limit up to which the induction of hypothermia may be neuroprotective, they did not investigate whether the extent of the intervention delay is influenced by the degree of cooling. Such a relation was demonstrated in the present study, where the effects of mild hypothermia on metabolic disturbances in fetal hippocampal slices were shown to depend on both the intervention delay and the degree of cooling. The longer the postischemic intervention delay and the lower the degree of hypothermia, the weaker the neuroprotective effect seems to be. This finding is consistent with investigations in adult animals demonstrating a close relationship between the onset of postischemic hypothermia and neuronal cell loss (18). Thus, in adult gerbils hypothermia of $32^{\circ} \mathrm{C}$ initiated $1 \mathrm{~h}$ after ischemia and continued for $24 \mathrm{~h}$ provided substantial protection in the CAl sector of the hippocampus. Although treatment delayed by $4 \mathrm{~h}$ also reduced hippocampal injury, the effect was significantly less than that of hypothermia initiated at I h $(15,16)$. In these studies the neuroprotective effect of delayed hypothermia also depended on the depth of cooling $\left(32^{\circ} \mathrm{C}\right.$ vs. $\left.34^{\circ} \mathrm{C}\right)(15,16,18)$.

From the results of the present study it is difficult to establish whether metabolic disturbances are affected by interaction between the severity of the ischemic insult and the length of intervention delay or the degree of cooling. Because hypothermia induced immediately after OGD improved the recovery of ATP concentrations in slices that had undergone 30 to $40 \mathrm{~min}$ of $\mathrm{OGD}$, but not in those subjected to $20 \mathrm{~min}$ of OGD. one may speculate that the neuroprotective effect of hypothermia is more pronounced after longer OGD-periods. However, this effect could not be observed in experiments investigating the recovery of PSR after OGD. where this variable returned almost to control values after 20 min of OGD. Furthermore, no significant differences in the recovery of ATP or of PSR could be detected between the two groups of slices that had undergone 30 and 40 min of ()GD, respectively.

One might speculate that inducing hypothermia after a long time delay after the primary insult may reverse its neuroprotective effect. In fact, we found that when hypothermia was started $4 \mathrm{~h}$ after GGD. ATP tissue concentrations in hippocampal slices that had undergone $20 \mathrm{~min}$ of OGD were significantly higher under normothermic conditions. However, at present there is no evidence in the literature to suggest that extending the postischemic time delay of hypothermia has any deleterious effect on cerebral tissue. To the best. of our. 
knowledge the side-effects of hypothermia seem to be determined chiefly by the degree and duration of the treatment (18).

The mechanisms by which mild hypothermia alleviates postischemic inhibition of protein synthesis are not fully understood. After ischemia, PSR is severely depressed throughout the brain but recovers in cerebral areas where the insult does not lead to cell death $(26,27)$. It also returns to control values in vulnerable regions, when the development of cell injury is blocked by therapeutic intervention (28). The inhibition of protein synthesis is caused by a blocking of the initiation step $(29,30)$ through increased phosphorylation of the eukaryotic initiation factor eIF-2 $\alpha$ (31). In eukaryotic cells this phosphorylation reaction is catalysed by the RNA doublestrand-activated protein kinase (PKR) (32). Besides viral infections, one important way to activate PKR is by disturbing endoplasmic reticulum (ER) calcium homeostasis $(33,34)$. It has been concluded, therefore, that a disturbance of ER calcium homeostasis may contribute to the postischemic suppression of protein synthesis and to the pathological processes producing ischemic cell injury, a view which is corroborated by the results of several studies (for review see: 35 ). Whether the neuroprotective effect of mild hypothermia arises from an alleviation of a postischemic disturbance of ER calcium homeostasis remains to be established in future experiments.

The alleviation of disturbances in energy metabolism after OGD in slices from the study group may be a consequence of the well-known inhibitory effect of hypothermia on cerebral metabolism (36,37), an effect helping to maintain intracellular energy stores (3842). Furthermore, as shown in a recent study in neonatal rats, secondary energy failure after a hypoxic-ischemic insult can be diminished by mild hypothermia (43). Thus, hypothermia of $24 \mathrm{~h}$ duration induced immediately after ischemia reduced the secondary decline of $\mathrm{PCr} / \mathrm{Pi}$ ratio from $0.48 \pm 0.22$ to $1.07 \pm 0.19$. On the other hand, the neuroprotective effect of mild hypothermia is not thought to result from a delay in the depletion of high energy phosphate during OGD. This was shown in a previous study on hippocampal slices from mature fetal guinea pigs (3). Whether alterations in polyamine metabolism interfere with the neuroprotective effect of mild hypothermia on metabolic disturbances after OGD remains to be established in further studies, $(44,45)$.

From the present study we conclude that hypothermia induced after OGD diminishes disturbances in energy metabolism and PSR in hippocampal slices from mature fetal guinea pigs. The extent of this effect depends on the intervention delay and the degree of cooling. The shorter the postischemic intervention delay and the greater the degree of hypothermia, the better the neuroprotective effect seems to be. 


\section{ACKNOWLEDGEMENT}

The excellent technical assistance of Stefan Reininghaus and Bianca Lammerding is gratefully acknowledged. This work was supported by the Deutsche ForschungsGemeinschaft (DFG Be 1688/4-1).

\section{REFERENCES}

1. Volpe JJ. Neurology of the Newborn. Philadelphia: WB Saunders Company, 1995

2. Berger R, Garnier Y. Pathophysiology of perinatal brain damage. Brain Res Brain Res Rev 1999:30: 107-34

3. Berger R, Jensen A, Hossmann KA, Paschen W. Effect of mild hypothermia during and after transient in vitro ischemia on metabolic disturbance in hippocampal slices at different stages of development. Dev Brain Res 1998:105:67-77

4. Bona E, Hagberg H, Loberg EM, Bagenholm R. Thoresen M. Protective effects of moderate hypothermia after neonatal hypoxic-ischemia: short-and long-term outcome. Pediatr Res 1998:43:738-45

5. Laptook AR, Corbett RJ, Sierett R, Burns DK, Tollefsbol G, Garcia D. Modest hypothermia provides partial neuroprotection for ischemic neonatal brain. Pediatr Res. 1994:35:436-42

0. Sirimanne ES, Blumberg RM, Bossano D, Gunning M, Edwards AD, Gluckman PD, Williams CE. The effectl of prolonged modification of cerebral temperature on outcome after hypoxic-ischemic brain injury in the infant rat. Pediatr Res 1996:39:591-7

7. Thoresen M, Bagenholm R, Loberg EM. A.pricena F, Kjellmer I. Posthypoxic cooling of neonatal rats provides protection against brain injury. Arch Dis Child Fetal Neonatal Ed 1996;74:F3-9

8. Thoresen M, Penrice J, Lorek A, Cady EB, Wylezinska M, Kirkbride V, Cooper CE, Brown GC, Edwards AD, Wyatt JS, et al. Mild hypothermia after severe transient. hypoxia-ischemia ameliorates delayed cerebral energy failure in the newborn piglet. Pediatr Res 1995:37:667-70

9. Trescher WH, Ishiwa S. Johnston MV. Brief post-hypoxic-ischemic hypothermia markedly delays neonatal brain injury. Brain Dev 1997:19:326-38

10. Yager J, Towfighi J. Vannucei RC. Influence of mild hypothermia on hypoxicischemic brain damage in the immature rat. Pediatr Res 1993;34:525-9

11. Gunn AJ, Gunn TR, de Haan HH, Williams CE, Gluckman PD. Dramatic neuronal rescue with prolonged selective head cooling after ischemia in fetal lambs. J Clin Invest 1997;99:248-56

12. Gunn AJ, Gunn TR, Gunning MD, Williams CE, Gluckman PD. Neuroprotection with prolonged head cooling started before postischemic seizures in fetal sheep. Pediatrics 1998:102:1098-106 
13. Carroll M, Beek O. Protection against hippocampal CAI cell loss by post-ischemic hypothermia is dependent on delay of initiation and duration. Metab Brain Dis $1992 ; 7: 45-50$

14. Coimbra C. Wieloch T. Moderate hypothermia mitigates neuronal damage in the rat brain when initiated several hours following transient ischemia. Acta Neuropathol 1994:87:325-31

15.Colbourne F, Corbett D. Delayed and prolonged post-ischemic hypothermia is neuroprotective in the gerbil. Brain Res 1994;654:265-72

16. Colbourne F, Corbett D. Delayed post-ischemic hypothermia: a sixth month survival study using behavioral and histologic assessments of neuroprotection. I Neurosi 1995:15:7250-60

17. Colbourne F, Li H, Buchan AM. Indefatigable CAI sector neuroprotection with mild hypothermia induced 6 hours after severe forebrain ischemia in rats. J Cereb Blood Flow Metab 1999;19:742-9

18. Colbourne F, Sutherland G, Corbett D. Postischemic hypothermia. Molec Neurobiol 1997:14:171-201

19. Berger R, Djuricic B, Jensen A, Hossmann K-A, Paschen W. Ontogenetic differences in energy metabolism and inhibition of protein synthesis in hippocampal slices during ischemia and 24 h of recovery. Dev Brain Res 1996:91:281-91

20. Hossmann K-A, Widmann R, Wiessner Ch, Dux E, Djuricic B, Röhn G. Protein synthesis after global ischemia and selective vulnerability. In: Krieglstein J, Oberpichler-Schwenk $\mathrm{H}$, eds. Pharmacology of Cerebral ischemia. Stuttgart: Wissenschaftliche Verlagsgesellschaft mbH, 1992:289-99

21. Penny JE, Kukums JR, Tyrer JH, Eadie MJ. Selective vulnerability of the hippocampus to hypoxia: cytophotometric studies of enzyme activity in single neurones. Proc Aust Assoc Neurol 1974:11:177-81

22. Djuricic B, Berger R, Paschen W. Protein synthesis and energy metabolism in hippocampal slices during extended ( 24 hours) recovery following different periods of ischemia. Metabol Brain Dis 1994:9:379-91

23. Atkinson DE. The energy charge of the adenylate pool as a regulatory parameter. Interaction with feedback modifiers. Biochem 1968;7:4030-4

24. Lowry OH, Rosenbrough NJ, Farr AL, Randall R. Protein measurement with the folin phenol reagent. J Biol Chem 1951:193:265-75

25. Gunn AJ, Bennet L, Gunning MI, Gluckman PD, Gunn TR. Cerebral hypothermia is not neuroprotective when started after postischemic seizures in fetal sheep. Pediatr Res 1999:46:274-80

26. Bodsch W, Takahashi K, Barbier A, Grosse Ophoff B, Hossmann K-A. Cerebral protein synthesis and ischemia. Progr Brain Res. 1985;63:197-210

27. Thilmann R, Xie Y, Kleihues P. Kiessling M. Persistent inhibition of protein synthesis precedes delayed neuronal death in postischemic gerbil hippocampus. Acta Neuropathol 1986;71:88-93 
28. Widmann R, Miyazawa T, Hossmann K-A. Protective effect of hypothermia on hippocampal injury after 30 minutes of forebrain ischemia in rats is mediated by postischemic recovery of protein synthesis. J Neurochem 1993;61:200-9

29. Cooper H, Zalewska T, Kawakami S, Hossmann K-A. The effect of ischemia and recirculation on protein synthesis in the brain. J Neurochem 1977;28:929-34

30. Hu BR, Wieloch T Stress-induced inhibition of protein synthesis initiation: modulation of initiation factor 2 and guanine nucleotide exchange factor activities following transient cerebral ischemia in the rat. J Neurosci $1993 ; 13: 1830-8$

31. Degracia DJ, Neumar RW, White BC, Krause GS. Global ischemia and reperfusionmodifications in eukaryotic initiation factors associated with inhibition of translation initiation. J Neurochem 1996;67:2005-12

32. Samuel CE. The elF-2 $\alpha$ protein kinases, regulators of translation in eukaryotes from yeast to humans. J Biol Chem 1993:268:7603-6

33. Prosiko CR, Dholakia JN, Brostrom MA, Brostrom CO. Activation of the doublestranded RNA-regulated protein kinase by depletion of endoplasmic reticulum calcium stores. J Biol Chem 1995:270:6211-5

34. Srivastava SP, Davies MV, Kaufman RJ. Calcium depletion from the endoplasmic reticulum activates the double-stranded RNA-dependent protein kinase (PKR) to inhibit protein synthesis. J Biol Chem 1995;270:16619-24

35. Paschen W. Disturbance of calcium homeostasis within the endoplasmic reticulum may contribute to the development of ischemic cell damage. Med Hypoth 1996;47:283-8.

36. Benedikt FC, Lee RC. Hibernation and marmot physiology. Publication no 494. Washington, DC: Carnegie Institution of Washington, 1938

37. Bigelow WG, Lindsay WK. Harrison RC. Oxygen transport and utilization in dogs at low body temperatures. Am J Physiol 1950;160;125-37

38. Kramer RS, Sanders AP, Lesage AM. The effect of profound hypothermia on preservation of cerebial ATP content during circulatory arrest. J Thorac Cardiovasc Surg 1968:56:699.709

39. Michenfelder JD. Theye RA. Hypothermia: effect on canine brain and whole body metabolism. Anaesthesiol 1968;29:1107-12

40. Michenfelder JD, Theye RA. The effects of anesthesia and hypothermia on canine cerebral ATP and lactate during anoxia produced by decapitation. Anaesthesiol $1970: 33: 430-9$

41. Sutton LN, Clark BJ, Norwood CR, Woodford EJ, Welsh FA. Global cerebral ischemia in piglets under conditions of mild and deep hypothermia. Stroke 1991:22:1567-73

42. Swain JA, McDonald Jr TJ, Balaban RS, Robbins RC. Metabolism of the heart and brain during hypothermic cardiopulmonary bypass. Ann Thorac Surg 1991:51:105-9

43. Nedelcu J, Klein MA, Aguzzi A, Martin E. Resuscitative hypothermia protects the neonatal rat brain from hypoxic-ischemic injury. Brain Pathol 2000:10:61-71 
44. Packianathan S, Cain CD, Liwnicz BH, Longo LD. Ornithine decarboxylase activity in vitro in response to acute hypoxia: a novel use of newborn rat brain slices. Brain Res 1995;688:61-71

45. Saito K, Packianathan S, Longo LD. Free radical-induced elevation of ornithine decarboxylase activity in developing rat brain slices. Brain Res 1997:763:232-8 
Chapter 9 


\section{Chapter 10}

\section{SUMMARY, CONCLUSIONS, AND FUTURE PERSPECTIVES}


Although perinatal brain injury is a major contributor to perinatal morbidity and mortality, present clinical strategies are not capable of reducing the incidence of perinatal hypoxicischemic brain damage significantly. However, a wealth of experimental studies has emerged describing the pathophysiological mechanisms that are implicated in perinatal brain injury (Chapter 2). These involve the acute breakdown of cerebral energy metabolism leading to the release of excitatory amino acids such as glutamate and aspartate. Glutamate binds to postsynaptically located glutamate receptors that regulate calcium channels. The resulting calcium influx activates proteases, lipases and endonucleases which in turn destroy the cellular skeleton. The acute lack of cellular energy arising during ischemia induces almost complete inhibition of cerebral protein biosynthesis. Once the ischemic period is over, protein biosynthesis returns to preischemic levels in non-vulnerable regions of the brain, while in more vulnerable areas it remains inhibited. The inhibition of protein synthesis therefore appears to be an early indicator of subsequeni neuronal cell death. A second wave of neuronal cell damage occurs during the reperfusion phase. This cell damage is thought to be caused by the postischemic release of oxygen radicals, synthesis of nitric oxide, inflammatory reactions and an imbalance between the excitatory and inhibitory neurotransmitter systems. Part of the secondary neuronal cell damage may be caused by induction of a kind of cellular suicide programme known as apoptosis. Recent studies have shown that inflammatory reactions not only exacerbate secondary neuronal damage after cerebral ischemia, but may also injure the immature brain directly. This damage seems to be brought about by the cardiovascular effects of endotoxins leading to cerebral hypoperfusion and by activation of apoptotic pathways in oligodendrocyte progenitors through the release of TNF- $\alpha$.

Since a significant proportion of neuronal cell damage is brought about by pathophysiological processes that first begin several hours or even days after an ischemic insult, the setting up of a therapeutic window would be feasible. Knowledge of these pathophysiological mechanisms has enabled scientists to develop new therapeutic strategies with successful results in animal experiments. The potential of such therapies was subject of the studies presented in this thesis, particularly the promising effects of the application of the calcium-antagonist flunarizine, the administration of magnesium and postischemic induction of mild cerebral hypothermia. 


\section{Flunarizine}

Since flunarizine, a class IV calcium antagonist, is a potent vasodilator, the neuroprotective properties of this drug may be counteracted by its cardiovascular side-effects. To clarify this point we subjected mature fetal sheep to acute intrauterine asphyxia (Chapter 4 ). Fetuses from the study group received flunarizine i.v. before asphyxia. During acute asphyxia there was a redistribution of cardiac output towards the central organs accompanied by a pronounced bradycardia and a progressive increase in arterial blood pressure. Fetuses of the study group had higher plasma catecholamine levels than the control group. After asphyxia, circulatory centralization did not resolve quite as rapidly as it had developed, but was almost completely recovered at $30 \mathrm{~min}$ after the insult. There were hardly any differences between treated animals and controls in the time course of physiological and cardiovascular variables measured before, during and after acute intrauterine asphyxia.

Given the key significance of the so-called calcium overload for the development of neuronal cell death we tested the neuroprotective effect of flunarizine, an antagonist of voltage-dependent calcium channels in a fetal sheep model (Chapter 5). Ischemic brain injury was caused by occlusion of both carotid arteries for $30 \mathrm{~min}$. One hour before the insult we applied the calcium-antagonist flunarizine at a concentration of $1 \mathrm{mg} / \mathrm{kg}$ fetal body weight i.v. This regimen reduced neuronal cell damage significantly, especially in the parasagittal cortex (Chapter 5). We conclude that pretreatment by low dose flunarizine protects the brain of fetal sheep near term from ischemic injury. We further conclude that this neuroprotective effect is not mediated by drug dependent changes in cerebral blood flow. Since low dose flunarizine does not alter the response of the fetal cardiovascular system to asphyxia, its clinical use should be reconsidered, particularly in fetuses that are at risk of hypoxic-ischemic encephalopathy.

\section{Lubeluzole}

During the last decade several in vitro and in vivo studies have shown that the benzothiazole compound lubeluzole is able to protect the brain from hypoxic-ischemic injury. In clinical studies the results were controversial. Protective and non-protective effects were seen in adult patients suffering from acute ischemic stroke. However, the knowledge on the safety profile and efficiency of lubeluzole seemed to be promising enough to warrant further studies in immature animals. We firstly studied the effects of lubeluzole on the fetal cardiovascular system (Chapter 6 ). Lubeluzole did not affect fetal circulatory centralisation during acute asphyxia in term fetal sheep. This mechanism is of major importance, since it protects the fetal brain from neuronal injury by increasing blood 
flow to the central organs, i.e. brain, heart, adrenals, when oxygen is in short supply. Because of these promising results, we further evaluated the neuroprotective properties of lubeluzole in fetal sheep. Unfortunately, we were unable to show any cerebroprotective effect of the drug on neuronal cell damage induced by transient global cerebral ischemia. This appears to be inconsistent with investigations in adult human beings (for detailed discussion see Chapter 7). However, in almost all of these studies models of focal instead of global cerebral ischemia were used. This type of cerebral ischemia is characterized by an ischemic core and a peri-infarct region known as ischemic penumbra. In this area, brain tissue is perfused at a level between the thresholds of functional impairment and of morphological integrity. Unless cerebral blood flow is rapidly improved in this region within a few hours after the insult, neuronal cell damage is the inevitable result. As shown previously, glutamate is released in tremendous amounts from the infarct core into the extracellular space after focal ischemia. The released glutamate activates the neuronal NOsynthase via calcium influx through NMDA-regulated calcium channels. In focal ischemia this pathway may be of greater importance for the development of neuronal cell damage than in global ischemia, since in the latter type of ischemia only a moderate and shortlasting increase in glutamate release has been observed. This may explain in part the differences in neuronal outcome between the present study and previous investigations after treatment of brain injury by lubeluzole.

\section{Magnesium}

In the clinical setuing, $\mathrm{MgSO}_{4}$ has been used widely used in obstetric practice for over 60 years. Its indications include suppression of preterm labor and management of pregnancyinduced hypertension. A retrospective epidemiological study by Nelson and Grether (1995) suggested that premature fetuses whose mothers received $\mathrm{MgSO}_{4}$ for the treatment of preeclampsia or as a tocolytic agent are less likely to develop cerebral palsy compared to a gestational age-matched group of fetuses not exposed to the drug. This difference was statisícally highly significant. Almost identical results were obtained in a retrospective study carried out by Schendel and co-workers (1996).

The neuroprotective efficacy of magnesium has been attributed to a variety of effects of this molecule on pathophysiological mechanisms during and after cerebral ischemia, i.e. vasodilation, inhibition of the NMDA-receptor, anti-convulsive properties. Furthermore, magnesium reduces the ischemia induced release of $\mathrm{NO}$ by blocking the NO-synthase (Chapter 8 ). NO is a free radical synthesized by NO-synthase in neurones and other cell types in response to rises in levels of intracellular calcium during and after ischemia. During reperfusion, $\mathrm{NO}$ and superoxide radicals combine to produce peroxynitrite, leading 
to the formation of more potent radicals. Destruction of cerebral tissue is the inevitable result. Since magnesium has been reported to block cerebral NMDA-receptors which themselves control calcium channels, the neuroprotective effect of magnesium may be mediated through an inhibition of NO-production after ischemia brought about by a reduction of neuronal calcium influx. On the strength of these results, several clinical studies have been conducted to test the effect of magnesium on the incidence of cerebral palsy in preterm fetuses. Recently, Mittendorf and co-workers (2002) reported a significant association between tocolytic $\mathrm{MgSO}_{4}$ exposure and total pediatric mortality rates from the MagNET trial. Children who had cord blood ionized magnesium levels above the measured cohor median level had significantly more adverse events - i.e. periventricular leukomalacia, intraventricular hemorrhage, cerebral palsy, and death - than occurred in those infants who had levels below the median. Thus, they found that combined adverse outcomes were associated with magnesium exposure in a dose-related fashion. Therefore, future studies have to be conducted to test the putative neuroprotective benefits of antenatal $\mathrm{MgSO}_{4}$ in the setting of premature labor.

\section{Mild hypothermia}

The induction of mild hypothermia has raised interesting possibilities for neuroprotection in cerebral ischemia. Over the last few years, the effect of mild hypothermia in protecting the brain from ischemically induced damage has been examined. Experimental studies on adult animals have shown that lowering of the brain temperature by $3-4^{\circ} \mathrm{C}$ during global. cerebral ischemia reduces neuronal cell damage dramatically. Furthermore, treated animals were found to perform better than controls in subsequent learning and behavioural tests. In the present study, we evaluated the exact interrelation between the postischemic time delay and the degree of mild hypothermia by which neuroprotective effects on ischemic insults of different severity can be achieved (Chapter 9). Therefore, we used the well described model of oxygen-glucose deprivation (OGD) in hippocampal tissue slices derived from mature fetal guinea pigs. Hypothermia initiated directly after OGD significantly improved the recovery of energy metabolism and protein synthesis. If there was a time delay of $2 \mathrm{~h}$ before the onset of hypothermia, neuroprotection depended on the degree of hypothermia. Reduction of the incubation temperature to $31^{\circ} \mathrm{C}$ diminished the disturbances of energy metabolism and protein, synthesis, whereas lowering the bath temperature to only $34^{\circ} \mathrm{C}$ was not effective. Inducing hypothermia $4 \mathrm{~h}$ after OGD did not have any influence on the recovery of energy metabolism and protein synthesis. These results tie in with studies. performed in fetal sheep. Based on these results, many authors now consider the induction of hypothermia during and particularly after a hypoxic-ischemic insult to be an effective therapeutic strategy. In fact, recent clinical safety studies have demonstrated that induction 
of mild cerebral hypothermia in newborn infants after perinatal asphyxia has no harmful side-effects and improves outcome in infants who suffered from moderate to severe encephalopathy (Gunn et al. 1998; Battin et al. 2001).

\section{FUTURE PERSPECTIVES ON PERINATAL NEUROPROTECTION}

Significant advances have been made over the past few years concerning the cellular and molecular events underlying hypoxic-ischemic brain injury. There are several new neuroprotective therapies available that have shown promise in animal and adult studies. Additional controlled, prospective trials are warranted, which hopefully will be designed and conducted within the next few years. The following paragraphs will briefly provide some new strategies which are currently under investigation (Table 3 ).

\section{Combination therapy}

The deleterious cascades that ensue following ischemia are many. It, therefore, stands to reason that an approach to neuroprotection that targets a single mechanism of action (e.g.. either calcium, glutamate or free radicals) is unlikely to be of maximal benefit. Consequently, some investigators have looked to combination treatments to try to achieve a beneficial synergistic or additive effect. Combination therapy may include, initially, a neuroprotective agent that preferably acts at multiple sites in the ischemic cascades (e.g. magnesium) to protect the brain from subsequent injury. This may be followed by by prevention of reperfusion injury, and finally we might administer treatment to improve plasticity in the developing brain (e.g., growth faciors, gene therapy, or stem cells).

\section{Creatine}

Mathews and co workers (1998) reported, that creatine protects the brain against malonateinduced increases in hydroxyl radical production and 3-nitropropionic-caused rise in 3nitrotyrosine concentration, a marker of peroxynitrite-mediated oxidative injury. In fetal and neonatal animals creatine supplementation alleviates inhibition of protein synthesis and reduces hypoxic-ischemic brain injury (Berger et al. in press). In vitro it was found, that the glutamate uptake into synaptic vesicles is stimulated by phosphocreatine even in the absence of added ATP. At a glutamate concentration of $50 \mu \mathrm{M}$. maximal phosphocreatine-stimulated glutamate uptake was significantly higher than that maximally stimulated by ATP (Xu et al., 1996). A mechanism by which creatine supplementation 
might protect the immature brain from ischemic injury could therefore be the activation of glutamate uptake into synaptic vesicles. Since creatine crosses the placental barrier and has been reported to accumulate in the brain of adults after oral supplementation (Dechent et al., 1999), further studies should be performed to test the neuroprotective efficacy of creatine on hypoxic-ischemic perinatal brain damage.

Table 3. New Therapies for Hypoxic-Ischemic Encephalopathy

\begin{tabular}{l}
\hline Hypothermia, brain only \\
MgSO $_{4}$ \\
Oxygen-free radical inhibitors, e.g. allopurinol \\
Calcium channel blockers, e.g. flunarizine \\
Inhibitors of nitric oxide production \\
Monoganglioside GM \\
NMDA receptor antagonists, e.g. MK-801 \\
Creatine \\
Phenobarbital \\
Melatonin \\
Cannabidiol \\
Nerve growth factor (NGF) \\
Glial cell line-derived neurotrophic factor (GDNF) \\
CO control \\
Glucocorticosteroids ? \\
Gene therapy? \\
Stem cells? \\
Combination of above \\
\end{tabular}

\section{Selective Nitric Oxide Synthase Inhibition by 2-Iminobiotin}

Recently, Peeters-Scholte and coworkers reported about the neuroprotective properties of selective NOS inhibition in the newborn piglet model of perinatal hypoxia-ischemia (Peeters-Scholte, 2002). They investigated the effects of NOS inhibition by 2-iminobiotin on histological outcome and clinical parameters, such as cerebral oxygenation, hemodynamics, and electrocortical brain activity. The drug provides selective inhibition of neuronal (nNOS) and inducible (iNOS), but not endothelial (eNOS) nitric oxide synthase. Intravenous application of 2 -iminobiotin preserved cerebral oxygenation and hemodynamics, and electrocortical brain activity. Moreover, 2-iminobiotin treatment improved cerebral energy state, reduced the amount of vasogenic edema, and decreased the apoptosis-related neuronal cell death. These promising neuroprotective effects of 2 iminobiotin treatment after hypoxia-ischemia remain to be confirmed in the human. 


\section{Melatonin}

Another interesting molecule under investigation is melatonin, a secretory product of the vertebrate pineal gland. Melatonin was recently shown to possess free radical scavenging activity, especially in the brain (for review: Reiter et al. 2001). This high efficacy may relate to the ease with which melatonin crosses the blood-brain barrier and to the fact that melatonin levels in the cerebrospinal fluid are orders of magnitude higher than in the blood. Furthermore, melatonin seems to lack significant toxicity and preliminary evidence in humans suggests that it may be protective against neurodegenerative disorders.

\section{Cannabidiol}

The non-psychoactive marijuana constituent, cannabidiol. can prevent both hypoxiaischemia induced giutamate neurotoxicity and oxygen radical induced cell death (for review: Hampson et al. 2000). Tetrahydrocannabinol the psychoactive constituent of Cannabis, also blocks neurotoxicity with a potency similar to that of cannabidiol. Using a glutamate neuronal toxicity model cannabidiol was demonstrated to be significantly more protective than either of the antioxidant vitamins, B-tocopherol or ascorbate. These properties of cannabinoids suggest they may have a therapeutic role as neuroprotectants, and the particular properties of cannabidiol make it a good candidate for such development.

\section{Glial cell line-derived neurotrophic factor}

Glial cell line-derived neurotrophic factor (GDNF), a protein in transforming growth factor $-B($ TGF- $B$ ) superfamily, was initially considered to be a specific trophic factor and neuroprotective agent for dopaminergic neurons (for review: Wang et al. 2002). Recent studies indicate that GDNF can protect the cerebral hemispheres from damage induced by middle cerebral arterial ligation. These effects are mediated through specific GDNF receptor alpha-1 (GFR1). Furthermore, it was shown that hypoxia-ischemia induced nitric oxide synthase (NOS) activity can be attenuated by GDNF.

\section{Gene Therapy}

Recently, it is becoming clear that some of genes induced during cerebral ischemia may actually serve to rescue the cell from death. However, the injured cell may not be capable of expressing protein at high enough levels to be protective. One interesting arena of such intervention is the use of viral vectors to deliver potentially neuroprotective genes at high levels (for review: Yenari et al. 2001). Recent scientific advances in the area of stroke and 
neurodegeneration have led to the discovery of specific cellular events that occur during necrosis and apoptosis. It is now possible to therapeutically target these events with the hope of rescuing brain cells from death. Several studies have shown that cerebral ischemia alters gene expression and that some of the induced genes may serve a protective or damaging role. Among the many genes that have been identified to participate in ischemia, those possessing neuroprotective properties may be candidates for gene therapy.

\section{Final Comment}

Neuroprotection of the developing brain can have an enormous impact on the quality of life of an individual and on public health. In the absence of appropriate neuroprotection, severe injury of a fetal or infant brain will result in lifelong disability. Neuroprotection of the immature brain is feasible, since short-term neuroprotection during critical periods of brain development can have life long effects in preserving normall neurological function. However, identification of the critical periods for neuroprotection against various insults remains an area in need of continued intensive study.

For the future, it is important to know what we don't know.

\section{REFERENCES}

1. Battin MR, Dezoete JA, Gunn TR, Gluckman PD, Gunn AJ 2001 Neurodevelopmental outcome of infants treated with head cooling and mild hypothermia after perinatal asphyxia. Pediatrics. 107:480-484.

2. Berger R, Middelanis J, Vaihinger HM, Mies G, Wilken B, Jensen A 2002 Creatine protects the immature brain from hypoxic-ischemic injury. Pediatr Res, in press.

3. Dechent P, Pouwels JW, Wilken B, Hanefeld F, Frahm J 1999 Increase of total creatine in human brain after oral supplementation of creatine-monohydrate. Am J Physiol 277:R698-R704.

4. Gunn AJ, Gluckman PD, Gunn TR 1998. Selective head cooling in newborn infants after perinatal asphyxia: a safety study. Pediatrics. 102:885-892. 
5. Hampson AJ, Grimaldi M, Lolic M, Wink D, Rosenthal R, Axelrod J 2000 Neuroprotective antioxidants from marijuana. Ann N Y Acad Sci 899:274-282.

6. Matthews RT, Yang L, Jenkins BG, Ferrante RJ, Rosen BR, Kaddurah-Daouk R, Beal MF 1998 Neuroprotective effects of creatine and cyclocreatine in animal models of Huntington's disease. J Neurosci 18:156-163.

7. Mittendorf R, Dambrosia J, Pryde PG, Lee KS, Gianopoulos JG, Besinger RE, Tomich PG 2002 Association between the use of antenatal magnesium sulfate in preterm labor and adverse health outcomes in infants. Am J Obstet Gynecol 186:1111-1118.

8. Nelson KB, Grether JK 1995 Can magnesium sulfate reduce risk of cerebral palsy in very low birthweight infants? Pediatrics 95:263-269.

9. Peeters-Scholte CM 2002 Neuroprotective strategies following perinatal hypoxiaischemia. Proefschrift. University of Utrecht, The Netherlands.

10. Reiter RJ, Acuna-Castroviejo D, Tan DX, Burkhardt S 2001 Free radical-mediated molecular damage. Mechanisms for the protective actions of melatonin in the central nervous system. Ann N Y Acad Sci 939:200-215.

11. Schendel DE, Berg CJ, Ycargin-Allsopp M, Boyle CA, Decougle P 1996 Prenatal magnesium sulfate exposure and the risk of cerebral palsy or mental retardation among very low-birth-weight children aged 3 to 5 years. JAMA 276:1805-1810.

12. Wang Y, Chang CF, Morales M, Chiang YH, Hoffer J 2002 Protective effects of glial cell line-derived neurotrophic factor in ischemic brain injury. Ann N Y Acad Sci 962:423-437.

13. Yenari MA, Dumas TC, Sapolsky RM, Steinberg GK 2001 Gene therapy for treatment of cerebral ischemia using defective herpes simplex viral vectors. Neurol Res 23:543-552.

14. Xu CJ, Klunk WE, Kanfer JN, Xiong Q, Miller G, Pettegrew JJW 1996 Phosphocreatine-dependent glutamate uptake by synaptic vesicles. A comparison with ATP-dependent glutamat uptake. J Biol Chem 271:13435-13440. 


\section{Hoofdstuk 10}

SAMENVATTING, CONCLUSSIE EN TOEKOMSTPERSPECTIEF 
Perinatale hersenbeschadiging is een belangrijke oorzaak van perinatale morbiditeit en mortaliteit. Met de huidige klinische detectiemethoden is het echter niet mogelijk de incidentie van perinatale hersenbeschadiging ten gevolge van hypoxie en/of ischaemie daadwerkelijk te beïnvloeden. Er zijn echter wel vele experimentele studies uitgevoerd die de pathofysiologische processen analyseren welke ten grondslag liggen aan perinatale hersenbeschadiging. Dit betreft onder meer de acute stilstand van de energievoorziening van de hersenen leidende tot het vrijkomen van prikkelende aminozuren zoals glutamaat en aspartaat. Glutamaat bindt zich aan postsynaptische glutamaat receptoren welke de calcium kanalen reguleren. De hieruit resulterende calcium influx activeert proteases, lipases en endonucleases welke vervolgens het cellulaire skelet vernielen. Het acute tekort aan cellulaire energie dat optreedt tijdens ischaemie veroorzaakt een nagenoeg algehele remming van de cerebrale eiwit aanmaak. Wanneer de ischaemische periode voorbij is, herstelt de eiwitsynthese zich tot het pre-ischaemische niveau in de minder kwetsbare gebieden van de hersenen terwijl deze productie op een lager niveau blijft in de meer kwetsbare gebieden.

Dientengevolge lijkt de verminderde eiwitproductie een vroege indicator te zijn voor de daaropvolgende dood van de zenuwcellen. Een tweede fase van zenuwcel beschadiging treedt op tijdens de reperfusie fase. Men veronderstelt dat deze celbeschadiging wordt veroorzaakt door het vrijkomen van zuurstof radicalen, de synthese van NO, ontstekingsreacties en een uit balans raken van stimulerende en remmende neurotransmitter systemen na de ischaemie. Een deel van deze secundair optredende neurogene schade wordt mogelijk veroorzaakt door het op gang komen van een cellulaire suïcideproces, apoptose genaamd. Recente studies lieten zien dat na cerebrale ischaemie ontstekingsreacties niet alleen secundaire neurogene schade bevorderen maar ook de immature hersenen direct beschadigen. Deze beschadiging lijkt te worden veroorzaakt door de cardiovasculaire effecten van endotoxinen waardoor cerebrale hypoperfusie ontstaat en door het activeren van apoptotische processen in voorlopers van de oligodendrocyten ten gevolge van het vrijkomen van TNF- $\alpha$.

Daar een belangrijk deel van de zenuwcelbeschadiging ontstaat door pathofysiologische processen, die pas uren of zelfs dagen na het ischaemisch insult beginnen, is het kunnen vasistellen van de juiste therapeutische periode van groot belang. De kennis van deze pathofysiologische mechanismen heeft het wel al mogelijk gemaakt nieuwe therapeutische strategieën te ontwikkelen met goede resultaten in dierexperimenten. De mogelijke effectiviteit van zulke therapieěn was het onderwerp van de studies gepresenteerd in dit 
proefschrift in het bijzonder de veelbelovende effecten van het toepassen van de calciumantagonist flunarizine, het toedienen van magnesium en het aanwenden van milde cerebrale hypothermie in de post ischaemische periode.

\section{Flunarizine}

Daar flunarizine, een klasse IV calcium antagonist, een krachtige vaatverwijder is, kunnen de beschermende eigenschappen van deze stof op het centrale zenuwstelsel geheel of gedeeltelijk teniet worden gedaan door de cardiovasculaire neveneffecten. Om dit probleem te analyseren onderwierpen we mature foetale schapen aan acute intrauteriene asphyxie (Hoofdstuk 4). Foetale lammeren uit de studiegroep kregen flunarizine intraveneus toegediend vóór het begin van de asphyxie. Tijdens acute asphyxie was er een herverdeling van de cardiac output naar de centrale organen, samen met een uitgesproken bradycardie en een toenemende arteriële bloeddruk. Foetale lammeren in de studiegroep hadden hogere plasma catecholamine spiegels dan in de controlegroep. Na de asphyxie, normaliseerde de centralisatie van de circulatie niet zo snel als deze was ontstaan: het herstel duurde ongeveer 30 minuten. Tussen de dieren in studie en de controlegroep bestonden nauwelijks verschillen in het tijdsverloop van de geregistreerde fysiologische en cardiovasculaire parameters voor, tijdens en na acute intrauteriene asphyxie.

Gezien de sleutelrol van de overmaat aan Ca-influx voor het ontstaan van celdood in het centrale zenuwstelsel werd de beschermende invloed van flunarizine, een Ca-influx antagonist, op het hersenweefsel van het foetale lam getest. (Hoofdstuk 5). Hieruit werd de conclusie getrokken dat voorbehandeling met een lage dosis flunarizine de hersenen van het bijna à terme foetale lam beschermt tegen ischaemische schade. Tevens werd de conclusie getrokken dat deze bescherming niet verloopt via flunarizine afhankelijke veranderingen in cerebrale bloeddoorstroming. Daar een lage dosering flunarizine de reactie van het cardiovasculaire systeem op asphyxie niet verandert zou klinisch gebruik heroverwogen moeten worden, vooral bij foetús welke risico lopen op hypoxischeischaemische hersenbeschadiging.

\section{Lubeluzol}

In vitro en in vivo studies, uit de laatste tien jaar toonden aan dat het benzothiazol derivaat lubeluzol in staat is de hersenen te beschermen tegen hypoxische-ischaemische schade. In klinische studies waren de resultaten tegenstrijdig. Beschermende en niet beschermende. effecten werden waargenomen bij volwassen patiënten met acuut herseninfarct. Echter het veiligheidsprofiel en effectiviteit van lubeluzol leek veelbelovend genoeg om verdere 
studies bij immature dieren te rechtvaardigen. Eerst werd het effect van lubeluzol op het foetale cardiovasculaire systeem onderzocht (Hoofdstuk 6). Lubeluzol beïnvloedde de centralisatie in de foetale circulatie niet tijdens acute asphyxie in voldragen foetale lammeren. Dit mechanisme is van groot belang daar het de foetale hersenen beschermt tegen celdood schade door de bloeddoorstroming naar de centrale organen (zoals hersenen, hart, bijnieren) te verhogen wanneer er zuurstoftekort dreigt. Op grond van deze veelbelovende resultaten werden voorts de beschermende effecten van lubeluzol op de hersenen van het foetale schaap onderzocht. Helaas kon geen enkel beschermend effect van deze stof op de schade in het centrale zenuwstelsel, geïnduceerd. door kortdurende algehele cerebrale ischaemie, worden gevonden. Dit lijkt in strijd met de bevindingen bij volwassenen (zie voor gedetailleerde overwegingen Hoofdstuk 7).

Echter in bijna al deze studies werd focale in plaats van globale cerebrale ischaemie gebruikt. Dit type cerebrale ischaemie wordt gekenmerkt door een ischaemische kern en. een gebied hieromheen, ischaemische penumbra genoemd. In dit gebied wordt het hersenweefsel doorstroomd op een niveau gelegen tussen de grens van functionele beperkingen en/of morphologische integriteit. Tenzij de hersendoorbloeding binnen een paar uur na het insult snel verbetert in dit gebied, is celbeschadiging het onvermijdbare resultaat. Zoals voorheen aangetoond, wordt glutamaat in grote hoeveelheid geproduceerd centraal in het infarct en getransporteerd naar de extracellulaire ruimte. Het vrijgekomen. glutamaat activeen de productie van $\mathrm{NO}$ in de hersenen door middel van $\mathrm{Ca}^{2+}$-influx via de NMDA-gereguleerde calcium kanalen. Bij focale ischaemie is dit mechanisme waarschijnlijk belangrijker voor het ontstaan van neurogene celbeschadiging dan bij globale ischaemie, daar bij globale ischaemie slechts een lichte en kortdurende stijging in de glutamaat productie wordt gezien. Dit zou gedeeltelijk het verschil in uitkomst tussen de huidige studie en voorafgaand onderzoek na behandeling van hersenbeschạdiging met lubeluzol, kunnen verklaren.

\section{Magnesium}

In de klinische obstetrie wordt magnesium sulfaat reeds meer dan zestig jạa gebrụikt voor de indicaties premature weeënactiviteit en de behandeling van pre-eclampsie. Nelson en Grether (1995) stelden op grond van een retrospectieve epidemiologische studie vast, dat in de groep prematuur geboren kinderen wiens moeders waren behandeld met magnesium sulfaat, hetzij wegens pre-eclampsie hetzij wegens premature weeënactiviteit, minder frequent ischaemische encephalopathie voorkwam dan in een voor de zwangerschapsduur gematchte groep kinderen waarvan de moeders niet met dit middel waren behandeld. Dit 
verschil was statistisch zeer significant. Vrijwel dezelfde resultaten werden vastgesteld in een retrospectieve studie uitgevoerd door Schendel et al. (1996).

Deze beschermende eigenschap van magnesium voor zenuwcellen wordt toegeschreven aan verschillende effecten van dit molecuul op de pathofysiologische mechanismen tijdens en na cerebrale ischaemie zoals vaatverwijding, remming van de NMDA-receptor, anticonvulsieve eigenschappen. Verder reduceert magnesium de door ischaemie geïnduceerde NO-productie door het blokkeren van de NO-synthase (Hoofdstuk 8). NO is een vrije radicaal gesynthetiseerd door NO-synthase in neuronen en andere celsoorten als reactic op de toename van intracellulair calcium tijdens en na ischaemie. Tijdens reperfusie produceren NO en vrije zuurstof radicalen samen peroxynitriet, hetgeen leidt tot de vorming van krachtiger radicalen, welke het hersenweefsel irreversibel beschadigen. Daar van magnesium is beschreven dat het cerebrale NMDA-receptoren kan blokkeren, die de calcium kanalen controleren, zou de beschermende werking van magnesium voor de hersencellen kunnen berusten op de remming van NO-productie na ischaemie door een reductie van $\mathrm{Ca}$-influx in de neuronen. Gebaseerd op de deze veelbelovende bevindingen zijn verschillende klinische studies uitgevoerd om het effect van magnesium op de incidentie van ischaemische encephalopathie na te gaan bij de premature foetus.

Recent rapporteerde Mittendorf et al. (2002) een significante associatie tussen $\mathrm{MgSO}_{4}$ toegediend als weeënremmer en de totale kindersterfie in de MagNet studie. Kinderen die navelstreng bloedspiegels van geïoniseerd magnesium hadden boven de vastgestelde mediaan van het bestudeerde cohort vertoonden significant meer negatieve gevolgen, onder meer PVL, IVH, CP, sterfte, dan kinderen waarbij deze concentratie zich onder de mediaan bevond. Dus zij vonden dat gecombineerde negatieve uitkomsten geassocieerd waren met het blootgesteld worden an magnesium in een dosisafhankelijke relatie. Dientengevolge moeten nieuwe studies worden uitgevoerd met $\mathrm{MgSO}_{4}$ om de veronderstelde beschermende werking op de hersenen van het voor de geboorte toedienen van deze stof als weeënremmer bij partus prematurus, nader te onderzoeken.

\section{Milde hypothermie}

De beschermende werking van milde hypothermie op de hersenen is de laatste jaren onderzocht en het toepassen hiervan biedt interessante mogelijkheden tot neuroprotectie. Experimentele studies bij volwassen dieren lieten zien dat verlaging van de hersentemperatuur met $3-4^{\circ} \mathrm{C}$, tijdens globale cerebrale ischaemie, de neurogene schade sterk beperkt. Daarenboven presteerden de behandelde dieren nadien beter dan de controledieren in leer- en gedragtesten. In deze studie onderzochten we de precieze relatie 
tussen het postischaemische tijdsverloop en de mate van milde hypothermie waarbij de beschermende werking kon worden bereikt bij ischaemische insulten van verschillende ernst (Hoofdstuk 9). Hiertoe maakten we gebruik van weefselcoupes uit de hippocampus van à terme foetal cavia's die werden blootgesteld aan een tekort aan zuurstof en glucose (het OGD model).

Hypothermie, toegepast direct na OGD, verbeterde het herstel van het energiemetabolisme en eiwitsynthese significant. Bij een interval van twee uur tussen noxe en hypothermie was de beschermende werking afhankelijk van de mate van hypothermie. Het terugbrengen van de incubatietemperatuur tot $31^{\circ} \mathrm{C}$ verminderde de verstoringen in het energiemetabolisme en de eiwitsynthese, terwijl het verlagen van de temperatuur tot maar $34^{\circ} \mathrm{C}$ niet effectief bleek. Het toepassen van hypothermie 4 uur na OGD had geen enkele invloed op het herstel van het energiemetabolisme en eiwitproductie. Deze resultaten zijn in overeenstemming met studies uitgevoerd bij foetale schapen. Gebaseerd op deze resultaten, beschouwen vele onderzoekers het toepassen van hypothermie, tijdens en vooral na een hypoxisch ischaemisch insult, als een effectieve therapeutische benadering. Recente klinische veiligheidsstudies toonden aan dat, milde cerebrale hypothermie bij asphyctische pasgeborenen, geen schadelijke bijwerkingen veroorzaakte en de uitkomst bij kinderen met matige tor ernstige encephalopathie verbeterde (Gunn et al. 1998; Bathin et al. 2001).

\section{DE TOEKOMST VAN PERINATALE NEUROPROTECTIE}

Gedurende de laatste jaren is er belangrijke voortgang geboekt in het ontrafelen van de cellulaire en moleculaire processen die ten grondslag liggen aan bypoxische-ischaemische hersenbeschadiging. Er zijn verschillende nieuwe neuroprotectieve therapieën beschikbaar gekomen die zowel in dierexperimenten als bij volwassenen veelbelovend zijn. Echter prospectieve gecontroleerde studies zijn noodzakelijk. De volgende paragrafen beschrijven kort enkele nieuwe strategieën welke momenteel onderwerp van studie zijn (Tabel 3).

\section{Combinatie therapie}

Na isçhaemie doen zich vele schadelijke processen voor die met elkaar zijn verweven. Het is daarom zeer onwaarschijnlijk dat goede neuroprotectie bewerkstelligd kan worden via één enkel werkingsmechanisme (bijvoorbeeld of calcium, glutamaat of vrije radicalen). Dientengevolge hebben sommige onderzoekers gezocht naar combinatie therapieën om 
synergische effecten te bereiken. Combinatie therapie kan initieel een neuroprotectieve stof betreffen, die bij voorkeur werkt op meerdere aangrijpingspunten in de keten van processen die op gang komen bij ischaemie (bijvoorbeeld magnesium). De volgende stap is het voorkomen van reperfusieschade, en tenslotte kan het toedienen van stoffen overwogen worden welke de plasticiteit van de zich ontwikkelende hersenen verbetert (bijvoorbeeld groeifactoren, gentherapie, stamcellen).

Tabel 3 Nieuwe Therapieěn Bij Hypoxische-Ischaemische Encephalopathie

Hypothermie van de hersenen alleen

$\mathrm{MgSO}_{4}$

Remmers van vrije zuurstofradicalen bijvoorbeeld allopurinol

Calcium kanaal blokkers bijvoorbeel flunarizine

Remmers van $\mathrm{NO}$ productie

Monoganglioside GM

NMDA receptor antagonisten, bijvoorbeeld MK-80I

Creatine

Phenobarbital

Melatonine

Cannabidiol

Nerve growth factor (NGF)

Glial cell line derived neurotrophic factor (GDNF)

$\mathrm{CO}_{2}$ controle

Glucocorticoiden ?

Gen therapie ?

Stamcellen?

Combinatie van bovenstaande

\section{Creatine}

Mathews et al. (1998) rapporteerden dat creatine de hersenen beschermd tegen de door maloneaat veroorzaakte toename van hydroxyl radicalen, en tegen de door 3-nitropropion veroorzaakte stijging van 3-nitrotyrosine, een marker van peroxynitriet gestuurde oxydatieve beschadiging. Bij foetale en neonatale dieren vermindert creatine de remming van eiwitsynthese en vermindert daarmee de mate van hypoxische ischaemische hersenbeschadiging (Berger et al., in druk). In vitro werd vastgesteld dat de glutamaat opname in de synaptische blaasjes wordt gestimuleerd door fosfocreatine zelfs in afwezigheid van toegevoegd ATP. Bij een glutamaat concentratie van $50 \mu \mathrm{M}$, was de maximale fosfocreatine gestimuleerde glutamaat opname significant hoger dan die welke maximaal gestimuleerd kon worden met ATP (Xu et al. 1996). Een mogelijk mechanisme waardoor creatine toediening de immature hersenen zou kunnen beschermen tegen 
ischaemische schade, zou het activeren van de glutamaat opname in de synaptische blaasjes kunnen zijn. Daar creatine de placenta passeert en bekend is dat het zich ophoopt in de hersenen van volwassenen (Dechent et al. 1999), zijn verdere studies welke de neuroprotectieve werking van creatine op hypoxische-ischaemische perinatale hersenschade bestuderen voor de hand liggend.

\section{Selectieve Nitric Oxide Synthase Inhibitie door 2-Iminobiotine}

In een recente publicatie van Peeters-Scholte et al. (2002) werden de neuroprotectieve eigenschappen van selectieve NOS inhibitie na perinatale hypoxie-ischemie in een neonataal biggenmodel beschreven. Zij onderzochten de effecten van NOS inhibitie door 2-iminobiotine op hersenweefsel en klinische parameters zoals cerebrale oxygenatie, hemodynamiek en electrische hersenactiviteit. 2-Iminobiotine veroorzaakte selectieve inhibitie van het neuronale ( $\mathrm{nNOS}$ ) en induceerbare (iNOS) NO synthase maar niet van het endotheliale (eNOS) enzym. Intraveneuze toediening van 2-iminobiotine hield de cerebrale oxygenatie, hemodynamiek en electrische hersenactiviteit in stand. Bovendien werd de energie status van de hersenen door 2-iminobiotine behandeling verbeterd, verminderde de hoeveelheid vasogeen oedeem en nam de kwantiteit van door apoptose geïnduceerde celdood af. Of deze veelbelovende neuroprotectieve eigenschappen van 2-iminobiotine na een episode van hypoxie-ischemie ook bij de mens effectief zijn, dient in verder onderzoek bevestigd te worden.

\section{Melatonine}

Een ander interessante stof in dit verband is melatonine, een stof geproduceerd bij vertebraten door de glandula pinealis. Van melatonine werd recent bekend dat het vooral in de hersenen vrije radicalen opruimt (voor overzicht zie Reiter et al. 2001). De grote efficiëntie waarmee dit gebeurt kan te danken zijn aan de gemakkelijke passage van melatonine door de bloed-hersen barrière alsmede aan het feit dat de melatonine concentratie in de cerebrospinale vloeistof zeer veel hoger is dan de concentratie in het bloed. Daarenboven lijkt melatonine niet giftig te zijn en voorlopige gegevens bij mensen suggereren dat het kan beschermen tegen neuro-degeneratieve ziekten.

\section{Cannabidiol}

Het niet psychoactieve marihuana bestanddeel, cannabidiol, kan zowel de door hypoxieischaemie geìnduceerde glutamaat neurotoxiciteit als de door vrije zuurstof radicalen geïnduceerde celdood voorkomen (voor overzicht zie Hampson et al. 2000). Tetrahydro- 
cannabinol, het psychoactieve bestanddeel van cannabis, blokkeert neurotoxiciteit eveneens in dezelfde mate als cannabidiol. In een glutamaat neurotoxisch model werkte cannabidiol significant beter beschermend dan de antioxydatieve vitamines $\beta$-tocopherol of ascorbinezuur. Deze eigenschappen van cannabinoiden wekken de suggestie dat ze een therapeutische rol kunnen spelen bij neuroprotectie en de specifieke eigenschappen van cannabidiol maken het voor dit doel een goede kandidaat.

\section{Glial cell line derived neurotrophic factor (GDNF)}

GDNF, een eiwit uit de transforming growth factor- $\beta$ (TGF- $\beta$ ) super familie, werd aanvankelijk beschouwd als een specifieke trophische factor en als een beschermende stof voor dopaminerge neuronen (voor overzicht zie Wang et al. 2002). Recente studies laten zien dat GDNF de cerebrale hemisferen kan beschermen tegen schade geînduceerd door het afklemmen van de a. cerebri media. Deze effecten verlopen via de specifieke GDNF receptor alpha-1 (GFR1), Voorts kon worden aangetoond dat door hypoxie-ischaemie geînduceerde NO-synthase (NOS) activiteit kan worden onderdrukt door GDNF.

\section{Gen therapie}

Recent is het duidelijk geworden dat het tot expressie komen van bepaalde genen tijdens cerebrale ischaemie tot doel heeft het voorkomen van celdood. Echter de beschadigde cel zou niet in staat kunnen zijn voldoende eiwit te produceren om de beschermende werking te kunnen waarborgen. Een interessant onderzoeksgebied in dit opzicht is het gebruik van virale vectoren om mogelijke neuroprotectieve genen tot expressie te laten komen (voor overzicht zie Yenari et al. 2001). Recente wetenschappelijke resultaten op het terrein van stroke en neurodegeneratie hebben geleid tot de ontdekking van specifieke cellulaire processen die optreden tijdens necrose en/of apoptose. Het is nu mogelijk deze specifieke cellulaire processen te beïnvloeden met als doel de dood van hersencellen te voorkomen. Uit verschillende studies blijkt dat cerebrale ischaemie de genexpressie verandert en dat sommige van de tot expressie gebrachte genen een beschermende of een beschadigende rol hebben. Onder de vele genen die een rol spelen bij ischaemie zijn die welke neuroprotectieve eigenschappen hebben kandidaten voor gen therapie. 


\section{SLOTCONCLUSIE}

Bescherming van de zich ontwikkelende hersenen bij dreigende schade kan van grote betekenis zijn op de kwaliteit van leven van een individu en op de maatschappij als geheel. Zolang de mogelijkheid van daadwerkelijke bescherming echter ontbreekt zal ernstige beschadiging van de foetale of neonatale hersenen uitmonden in levenslange invaliditeit.

Indien het mogelijk wordt de exacte intervallen tussen het hypoxische-ischaemische insult en de mogelijke adequate therapie waarbinnen deze moet worden ingesteld, te definiëren dan lijkt bescherming van de hersenen haalbaar.

Voor de toekomst is het belangrijk te weten wat we niet weten.

\section{REFERENCES}

1. Battin MR, Dezoete JA, Gunn TR, Gluckman PD, Gunn AJ 2001 Neurodevelopmental outcome of infants treated with head cooling and mild hypothermia after perinatal asphyxia. Pediatrics. 107:480-484.

2. Berger R, Middelanis J, Vaihinger HM, Mies G, Wilken B, Jensen A 2002 Creatine protects the immature brain from hypoxic-ischemic injury. Pediatr Res, in press.

3. Dechent P. Pouwels JW, Wilken B, Hanefeld F, Frahm J 1999 Increase of total creatine in human brain after oral supplementation of creatine-monohydrate. Am J Physiol 277:R698-R704.

4. Gunn AJ, Gluckman PD. Gunn TR 1998 Selective head cooling in newborn infants after perinatal asphyxia: a safety study. Pediatrics. 102:885-892.

5. Hampson AJ, Grimaldi M, Lolic M, Wink D, Rosenthal R, Axelrod J 2000 Neuroprotective antioxidants from marijuana. Ann N Y Acad Sci 899:274-282.

6. Matthews RT, Yang L, Jenkins BG, Ferrante RJ, Rosen BR, Kaddurah-Daouk R, Beal MF 1998 Neuroprotective effects of creatine and cyclocreatine in animal models of Huntington's disease. J Neurosci 18:156-163.

7. Mittendorf R, Dambrosia J, Pryde PG, Lee KS, Gianopoulos JG, Besinger RE, Tomich PG 2002 Association between the use of antenatal magnesium sulfate in preterm labor and adverse health outcomes in infants. Am J Obstet Gynecol 186:1111-1118.

8. Nelson KB, Grether JK 1995 Can magnesium sulfate reduce risk of cerebral palsy in very low birthweight infants? Pediatrics 95:263-269. 
9. Peeters-Scholte CM 2002 Neuroprotective strategies following perinatal hypoxiaischemia. Proefschrift. University of Utrecht, The Netherlands.

10. Reiter RJ, Acuna-Castroviejo D, Tan DX, Burkhardt S 2001 Free radical-mediated molecular damage. Mechanisms for the protective actions of melatonin in the central nervous system. Ann N Y Acad Sci 939:200-215.

11. Schendel DE, Berg CJ, Ycargin-Allsopp M, Boyle CA, Decougle P 1996 Prenatal magnesium sulfate exposure and the risk of cerebral palsy or mental retardation among very low-birth-weight children aged 3 to 5 years. JAMA 276:1805-1810.

12. Wang Y, Chang CF, Morales M, Chiang YH, Hoffer J 2002 Protective effects of glial cell line-derived neurotrophic factor in ischemic brain injury. Ann N Y Acad Sci 962:423-437.

13. Yenari MA, Dumas TC, Sapolsky RM, Steinberg GK 2001 Gene therapy for treatment of cerebral ischemia using defective herpes simplex viral vectors. Neurol Res 23:543-552.

14. Xu CJ, Klunk WE, Kanfer JN, Xiong Q, Miller G, Pettegrew JJW 1996 Phosphocreatine-dependent glutamate uptake by synaptic vesicles. A comparison with ATP-dependent glutamat uptake. J Biol Chem 271:13435-13440. 
PUBLICATIONS 


\section{A. THESIS (MD)}

Garnier Y (1998). Der Glutamatantagonist Lubeluzole in der Therapie der globalen zerebralen Ischämie. Eine Untersuchung an geburtsreifen Schaffeten in utero. University of Bochum, Germany. Shaker Verlag, Aachen, Germany

\section{B. ORIGINAL ARTICLES}

10. Garnier Y, Middelanis J, Jensen A, Berger R (2002) Neuroprotective effects of magnesium on metabolic disturbances in fetal hippocampal slices after oxygenglucose deprivation: Mediation by nitric oxide system. Journal of the Society for Gynecologic Investigation, 9, 86-92

9. Garniex Y, Löbbent T, Jensen A, Berger R (2002) Lubeluzole pretreatment does not provide neuroprotection against transient global cerebral ischemia in fetal sheep near term. Pediatric Research, 51, 517-522

8. Garnier Y, Pfeiffer D, Jensen A, Berger R (2001) Effects of mild hypothermia on metabolic disturbances in fetal hippocampal slices after oxygen/glucose deprivation depend on depth and time delay of cooling. Journal of the Society for Gynecologic Investigation, 8, 198-205.

7. Garnier Y, Coumans A, Jensen A, Berger R, Hasaart THM (2001) Endotoxemia severely affects circulation during normoxia and asphyxia in immature fetal sheep. Journal of the Society for Gynecologic Investigation, 8, 134-142

6. Berger R, Garnier Y, Löbbert T. Pfeiffer D, Jensen A (2001) Circulatory responses to acute asphyxia are not affected by the glutamate antagonist lubeluzole in fetal sheep near term. Journal of the Society for Gynecologic Investigation, 8, I43-148

5. Berget R, Garnier Y. Pfeiffer D, Jensen A. (2000) Lipopolysaccharides do not alter energy metabolism and protein synthesis in an in vitro model of fetal cerebral ischemia. Pediatric Research, 48, 531-535

4. Berger R, Lehmann T, Karcher J, Garnier Y. Jensen A (1998) Low dose flunarizine protects the fetal brain from ischemic injury in sheep. Pediatric Research, 44, I-6 
3. Garnier Y, Berger R, Pfeiffer, D, Jensen A (1998) Low dose flunarizine does not affect short term fetal circulatory responses to acute asphyxia in sheep near term. Reproduction, Fertility and Development, 10,405-411

2. Coumans ABC, Garnier Y. Supçun S, Jensen A, Hasaart THM, Berger R (2002) The role of nitric oxide on fetal cardiovascular control during normoxia and acute hypoxia in mid-gestation sheep. Journal of the Society for Gynecologic Investigation. submitted

1. Coumans A, Middelanis J, Garnier Y, Vaihinger HM, Leib SL, von Duering M, Hasaart THM, Jensen A, Berger R (2002) Intracisternal application of endotoxin aggravates hypoxic-ischemic brain damage in neonatal rats. Pediatric Research in press

\section{REVIEW ARTICLES}

11. Garnier Y, Berger R (2002) Perinatale Neuroprotektion. Pädiarrische Praxis, 61, 13. 26

10. Berger R, Garnier Y. Jensen A (2001) Perinatale Neuroprotektion: Ist eine Senkung der zerebralen Morbidität möglich? Deutsches Ärzteblatı, 98, 1124-1128

9. Berger R, Garnier Y (2000) Perinatal brain injury. Journal of Perinatal Medicine, 28, 261-285

8. Berger R, Garnier Y (1999) Pathophysiology of perinatal brain damage. Brain Research Brain Research Reviews, 30, 107-134

7. Jensen A. Garnier X. Berger R (1999) Dynamics of fetal circulatory responses to hypoxia and asphyxia. European Journal of Obstetrics and Gynaecology, 84, I55- 172

6. Berger R. Garnier Y (1999) Die Frühgeburt: Pathogenese, Risikoselektion und präventive Maßnahmen. Geburtshilfe und Frauenheilkunde, 59, 45-56

5. Berger R, Garnier Y. Jensen A (1999) Protektion des kindlichen Gehirns durch sanfte und sichere Geburtsleitung. Gynäkologe, 1, 55-59 
4. Berger R, Garnier X (1998) Pathophysiologie perinataler Hirnschäden. Gynäkologe, $31,1-19$

3. Berger R, Garnier $Y$, Jensen A (2002) Perinatal brain damage: Underlying mechanisms and neuroprotective strategies. Journal of the Society for Gynecologic Investigation, in press

2. Garnier Y, Berger R (2002) Bedeutung der intrauterinen Infektion für Frühgeburtlichkeit und perinatale Hirnschäden. Hebamme, in press

1. Jensen A, Garnier Y, Middelanis J, Berger R. Perinatal brain damage - from pathophysiology to prevention. European Journal of Obstetrics and Gynaecology, in press 


\title{
Curriculum vitae
}

\section{YVES GARNIER}

\begin{abstract}
Address Universitätsfrauenklinik Bochum
Knappschaftskrankenhaus

In der Schornau 23-25, 44892 Bochum, Germany

email: yves.garnier@ruhr-uni-bochum.de
\end{abstract}

Date of Birth

November 16, 1970

Spouse

Dr. phil, Claudia Felicitas Garnier

Children

Marie Florence, * June 27, 1998

Anne Claire, * May 7, 2002

\section{EDUCATION AND TRAINING}

\section{University}

1991-95 Bachelor in Human Medicine, University of Marburg, Germany

1995-96 Bachelor in Human Medicine, University of Hamburg. Germany

1996-97 Bachelor in Human Medicine, University of Bonn, Germany

1995-98 Research Assistent, Dept Ob/Gyn, University of Bochum, Germany

1998- Residency. Dept Ob/Gyn,University of Bochum

\section{ACADEMIC APPOINTMENTS}

1991-95 Research Assistent, Perinatal Research Group (Head Prof. Dr. med. A. Jensen) University of Giessen, Germany

1995-03 Research Fellow, Perinatal Research Group (Head Prof. Dr. med. A. Jensen, PD Dr, med. R. Berger) University of Bochum, Germany

1999 Doctoral Dissertation (Dr. med.) summa cum laude, University of Bochum, Germany 
Postdoctoral Fellowship:

1998-2002 Institute for Growth and Development (GROW), Prof. Dr. Jelte de Haan, Scientific Director, University of Maastricht, Netherlands

12/98-03/99 Project I Does Endotoxemia Affect Circulatory Responses to Acute Asphyxia in Immature Fetal Sheep?

12/99-03/00 Project II Pathophysiological Pathways of Fetal Endotoxemia.

12/00-03/01 Project III Do Lipopolysaccharides Mediate Perinatal Brain Damage in Immature Fetal Sheep?

\section{AWARDS}

1999 I. Wissenschaftspreis fuir "Geburtshilfe und Perinatalmedizin" der Niederrheinisch-Westfälischen Gesellschaft für Gynäkologie und Geburtshilfe, Münster

Garnier Y, Jensen A, Berger R

Endotoxine - Auswirkungen auf Energiemetabolismus und Proteinbiosynthese in einem in vitro Modell der fetalen zerebralen Ischämie.

1999 Graduierten-Stipendium der Novartis-Stifung für therapeutische Forschung und der Medizinischen Fakultät der Ruhr-Universität Bochum

Garnier Y

Der Glutamatantagonist Lubeluzole in der Therapie der globalen zerebralen Ischämie. Eine Untersuchung an geburtsreifen Schaffeten in utero.

2000 President's Presenter Award, 47th Annual meeting of the Society for Gynecologic Investigation. Chicago, USA.

Garnier Y, Coumans A, Berger R, Jensen A, Hasaart THM

Circulatory changes during endotoxemia may contribute to fetal brain damage in preterm sheep. 
2000 I. Wissenschaftspreis der Niederrheinisch-Westfalischen Gesellschaft für Gynäkologie und Geburtshilfe, Düsseldorf

Middelanis J, Garnier Y, Pfeiffer D, Jensen A, Berger R

Magnesium schützt fetale hippokampale Gewebescheiben vor ischlimischen Låsionen.

2001 1. Wissenschaftspreis der Niederrheinisch-Westfulischen Gesellschaft fiur Gynäkologie und Geburtshilfe, Essen

Garnier Y, Coumans A, Supçun S, Jensen A, Hasaart T, Berger R

Fetaler Endotoxinschock - Bedeutung des Stickstoffmonoxid-Systems.

2001 2. Wissenschaftspreis der Niederrheinisch-Westfalischen Gesellschaft für Gynäkologie und Geburtshilfe, Essen

Middelanis J, Coumans A, Garnier X. Leib S, Jensen A, Hasaart T, Berger R Endotoxine verstärken einen hypoxisch-ischämischen Hirnschaden bei der neonatalen Ratte. 


\section{ACKNOWLEDGEMENTS}

The present thesis is the result of many years of work. Therefore, numerous people participated not only in the research work, but also in my formation as Obstetrician and Gynecologist. I would like to manifest my gratitude to all of them.

I am deeply grateful to my promotor, Professor dr. Arne Jensen, for his continual guidance, advice, support and encouragement throughout my graduate and postdoctoral career.

I am also grateful to my promotor, Professor dr. Jelte de Haan, for his invitation to the Institute for Growth and Development (GROW), University Hospital Maastricht and giving me the opportunity to present this thesis.

Moreover, I am deeply grateful to my teacher in science and friend, Professor dr. Richard Berger. Dear Richard, your amazing energy and broad spectrum of research interests have provided a constant example to me of a dedicated scientist, and your advice on the practical sides of research have educated me in the world' of professional science.

I also thank Professor dr. Mark Hanson for his critical, helpful and inspiring comments on the manuscript, which enabled me to substantially improve it.

The excellent technical assistance of Harald Klossek', Otmar Adam', Dorothea Ehler', Monika Nickel', Bianca Lammerding ${ }^{2}$ and Stefan Reininghaus ${ }^{2}$, Departments of Obstetrics and Gynecology, Universities of Giessen' and Bochum², Germany is gratefully acknowledged.

I would like to acknowledge the significant contribution made by the following institutions and organisations to the development of the material presented in this book:

Deutsche Forschungsgemeinschaft

FoRUM, University of Bochum, Germany

Heinrich und Alma Vogelsang Stiftung, Bochum, Germany

Novartis Stiftung für Therapeutische Forschung, Nürnberg, Germany.

On a personal note. I am very gratefụ! to my spouse, Dr. Claudia Garnier, whithout whom this project, as well as a great deal of my personal happiness, would not have been possible. This book is dedicated to you 
Perinatal brain damage is a major cause of subsequent neurological disability in both premature and term infants. Although multiple causes, e.g., hypoxia-ischemia, hemorrhage, infection, metabolic derangement, are recognized, hypoxic-ischemic disease predominates. During the past decade, a wealth of experimental studies has emerged describing the pathophysiological mechanisms that are implicated in perinatal brain injury. Knowledge of these pathways has enabled scientists to develop new therapeutic strategies which have been shown to be neuroprotective in perinatal animal and adult studies. The potential of such therapies in perinatal medicine is subject of the present book, particularly the promising effects of postischemic induction of mild cerebral hypothermia, the application of calcium channel blockers and the administration of magnesium.

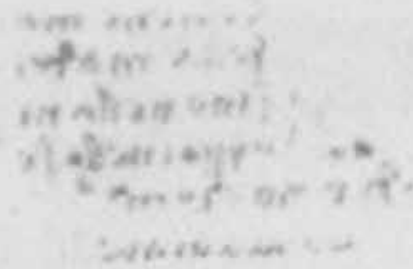

